\title{
A Study of the Costs and Benefits of a Formal Safety Program
}

\author{
Thomas R. Crites
}

March 1993

- This is an informal report intended primarily for internal or limited external distribution. The opinions and conclusions stated are those of the author and may or may not be those of the Laboratory.

Work performed under the auspices of the U.S. Department of Energy by the Lawrence Livermore National Laboratory under Contract W-7405-Eng-48.

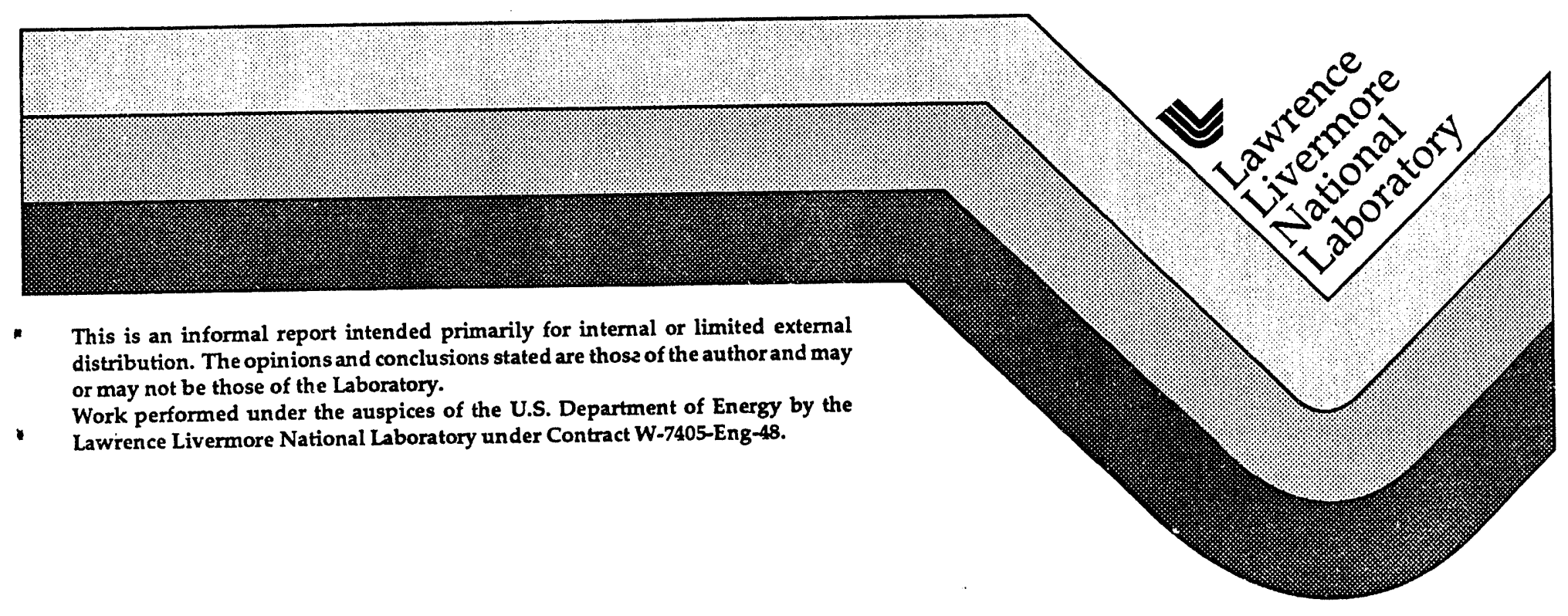




\section{DISCLAIMER}

This document was prepared as an acccount of work sponsored by an agency of the United States Government. Neither the United States Covernment nor the University of California nor any of their employees, makes any warranty, express or implied, or assumes any legal liability or responsibility for the accuracy, completeness, or usefulness of any information, apparatus, product, or process disclosed, or represents that its use would not infringe privately own rights. Reference herein to any specific commercial products, process, or service by trade name, trademark, manufacturer, or otherwise, does not necessarily constitute or imply its endorsement, recommendation, or favoring by the United States Government or the University of California. The views and opinions of authors expressed herein do not necessarily state or reflect those of the Uniten States Government or the University of California, and shall not be used for advertising or product endorsement purposes.

This report has been reproduced directly from the best available copy.

A vailable to DOE and DOE contractors from the Office of Scientific and Technical Information P.O. Box 62, Oak Ridge, TN 37831

Prices available from (615) 576-8401, FTS 626-8401

Available to the public from the National Technical Information Service

U.S. Department of Commerce

5285 Port Royal Rd.

Springtield, VA 22161 


\section{Contents}

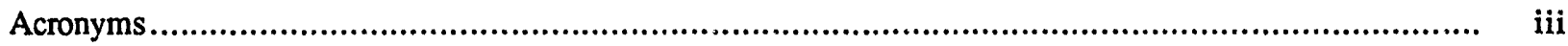

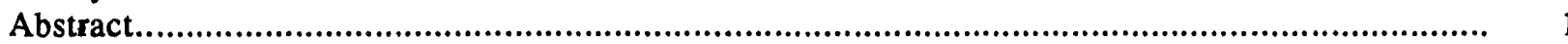

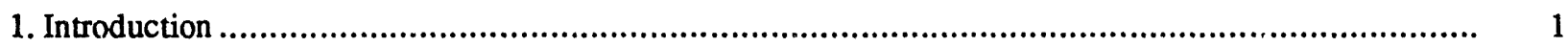

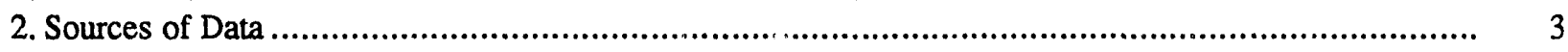

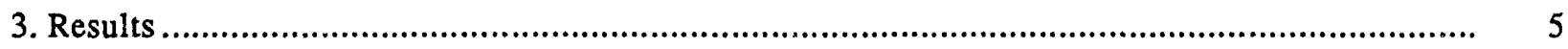

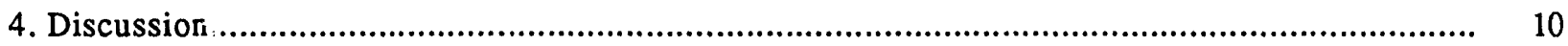

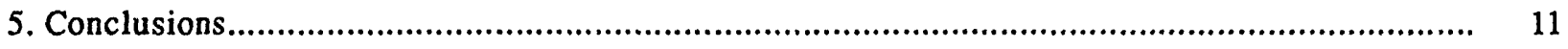

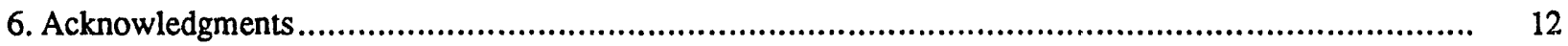

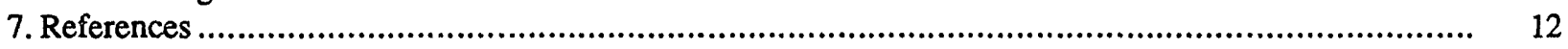

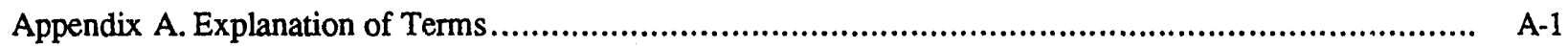

Appendix B. Data Summary Tables............................................................................................... B-1

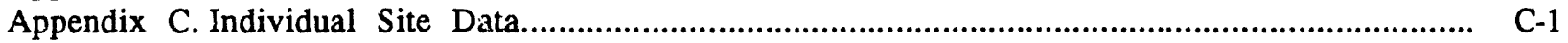

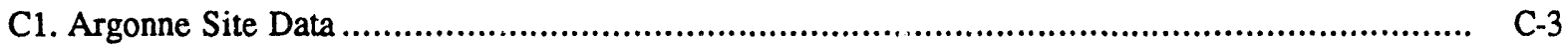

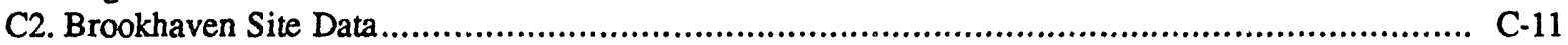

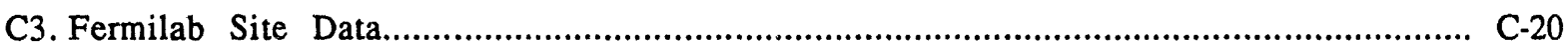

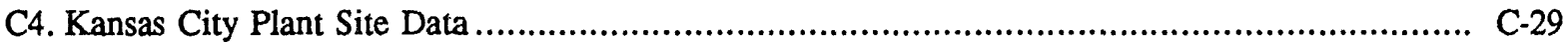

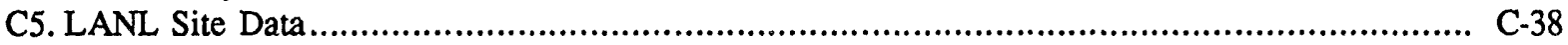

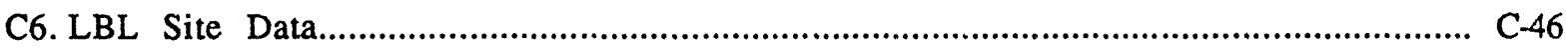

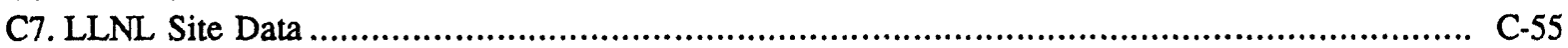

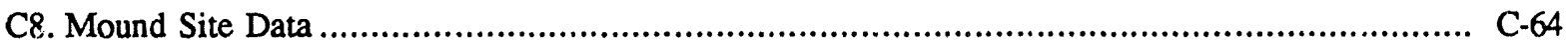

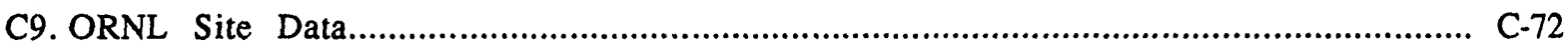

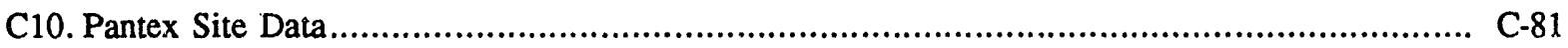

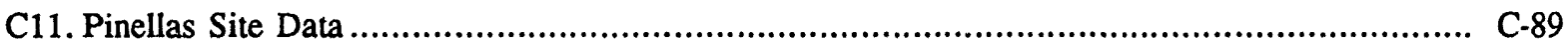

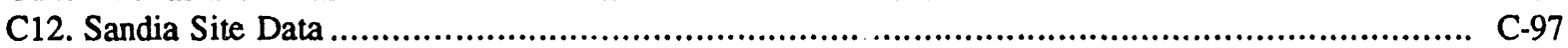

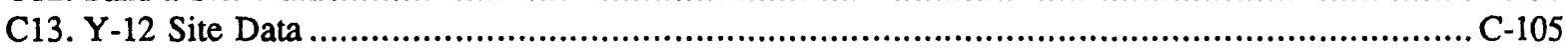

\section{List of Figures}

Figure 1. Total of safety budgets of sites surveyed in this study over 11 years........................................

Figure 2. Total of safety staffs of sites surveyed in this study over 11 years ........................................ 2

Figure 3. Safety budget and staff as a percentage of total facility operating budget and staff........................ 2

Figure 4. DOE contractor safety performance over 11 years.......................................................................... 2

Figure 5. Theoretical relationship between safety investment and accident costs.................................... 2

Figure 6. DOE contractor safety performance (LWD rate) by contractor type over 11 years............................. 4

Figure 7. Safety costs minus accident costs for contractors studied, 1980-1989 average................................ 5

Figure 8. Safety costs minus accident costs for contractors studied, 1980-1984 average................................ 5

Figure 9. Safety costs minus accident costs for contractors studied, 1990................................................... 6

Figure 10. LWD rate compared to percent of site budget spent on safety, 1980-1989 average ...................... 6

Figure 11. LWD rate compared to percent of site personnel committed full time to safety, 1980-1989 average.....

Figure 12. Percent of contractor staff in safety compared to the percent of staff lost accidentally per year, 1980-1989 average.

Figure 13. Average safety personnel compared to average lost manpower, 1980-1989 average............................ 7

Figure 14. Total reportable case rate compared to percent of site budget spent on safety, 1980-1989 average.

Figure 15. Total reportable case rate compared to percent of site personnel committed full time to

Fafety, 1980-1989 average ................................................................................................ lost through accident, 1980-1989 average ..

Figure 17. Average safety investment compared to average dollar loss, 1980-1989 average ..........................

Figure 18. LWD rate compared to percent of site budget spent on safety, 1990. 6.

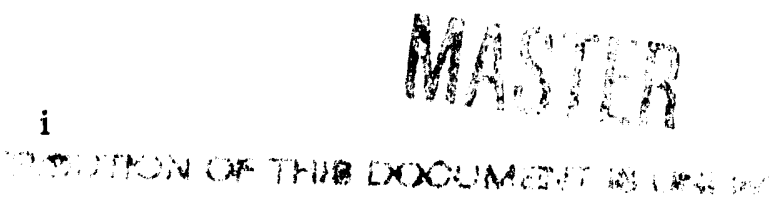


Figure 19. LWD rate compared to percent of site personnel committed full time to safety, 1990

Figure 20. Percent of contractor staff in safety compared to the percent of staff lost accidentally

per year, 1990

Figure 21. Safety personnel compared to lost manpower, 1990

Figure 22. Total reportable case rate compared to percent of site budget spent on safety, 1990

Figure 23. Percent of contractor budget invested in safety compared to percent of contractor budget

lost through accident, 1990

Figure 24. Safety investment compared to dollar loss, 1990.

Figure 25. LWD rate compared to percent of site budget spent on safety, 1980-1984 average

Figure 26. LWD rate compared to percent of site budget spent on safety, 1985-1989 average

Figure 27. Worker's compensation cost dependency on safety program percent of operating

budget, 1990

Figure 28. Total loss dependency on safety program, 1990

Figure 29. Radiation exposure of DOE contractor employees. (Reproduced from Ref. 9.)

Figure 30. LWD rate comparison between DOE and general industry

8

8

9

9

9

9

10

10

11

11

List of Tables

Table 1. DOE contractor sites studied 


\section{Acronyms}

BLS Bureau of Labor Statistics

DOE Department of Energy

$\mathrm{EH}$ Office of Environment, Safety and Health

FTE full-time equivalent

GNP gross national product

GOCO Government-owned, contractor-operated

ICRP International Commission on Radiological Protection

LANL Los Alamos National Laboratory

LBL Lawrence Berkeley Laboratory

LLNL Lawrence Livermore National Laboratory

LWC lost workday cases

LWD lost workday, or workdays

NRC Nuclear Regulatory Commission

ORNL Oak Ridge National Laboratory

OSHA Occupational Safety and Health Administration

TRC total recordable cases

W.C. worker's compensation 


\title{
A Study of the Costs and Benefits of a Formal Safety Program
}

\author{
Thomas R. Crites
}

\begin{abstract}
This study reports on a review of the safety programs and performance at 13 Department of Energy contractor facilities, involving over one-half million man-years of experience. Safety performance was compared with the size of staff and safety department funding over an 11-year period (1980-1990).

Indicators of safety performance were taken as lost workdays, recordable injuries, accidental dollar losses, worker radiation dose, and worker's compensation expenditures. Safety performance was found to be independent of, or even inversely related to, safety investment. Those organizations with the largest safety programs also experienced the greatest accidental losses.
\end{abstract}

\section{Introduction}

The Department of Energy (DOE) administers a broad range of Government-owned laboratories and production facilities, operated by contractor organizations representing industry, universities, and nonprofit organizations (referred to as GOCO facilities). Programs are administered by a staff located in Washington, D.C., which exercises central responsibility for policy, overall planning, direction, and management of Departmental activities. DOE has an extensive field structure that plays an integral part in the management and evaluation of Departmental projects and programs.

The Department has traditionally supported strong safety programs at its contractor-operated sites, with emphasis on performance, and, more recently, compliance to regulation. DOE is responsible for the development and establishment of policies and structures that assure safety and health protection in all DOE activities as well as the appraisal of safety performance at its facilities. Further, DOE assures compliance with applicable national statutes, regulations, standards, and processes. Routine auditing for quality and tracking of performance have been a trademark of the administration of contractor programs. Funding support for safety programs has generally been very strong at all DOE sites.
Figures 1 and 2 show the total safety funding and staffing for those sites examined in this study. In Fig. 1, dollar values were normalized to 1990 values through the use of an implicit price deflator for nominal year values based on GNP. These values are plotted as a percentage of the total facility budget and manpower in Fig. 3. Figure 4 shows DOE's total lost workday (LWD) and total recordable injury (TRC) rates over the period of this study for the contractors. There is little

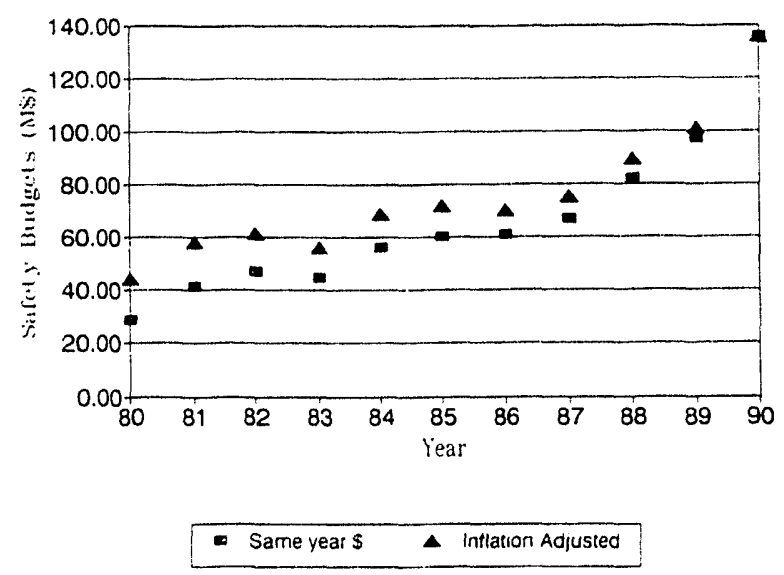

Figure 1. Total of safety budgets of sites surveyed in this study over 11 years. 


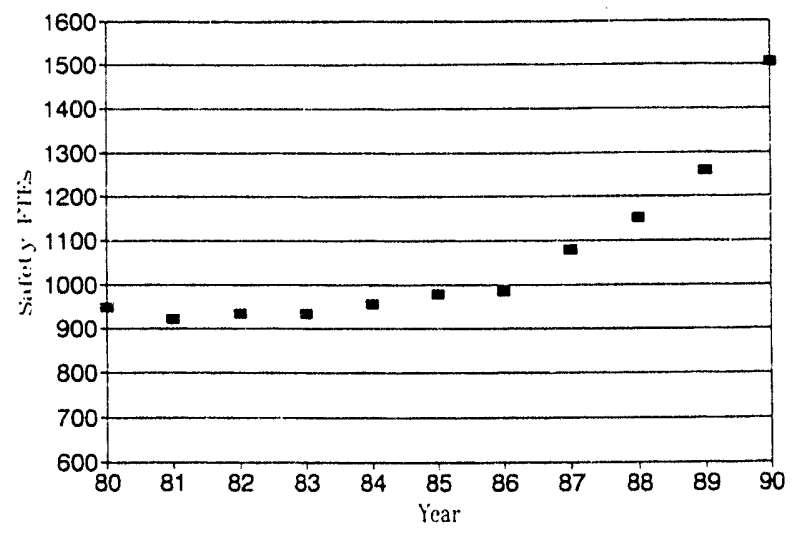

Figure 2. Total of safety staffs of sites surveyed in this study over 11 years.

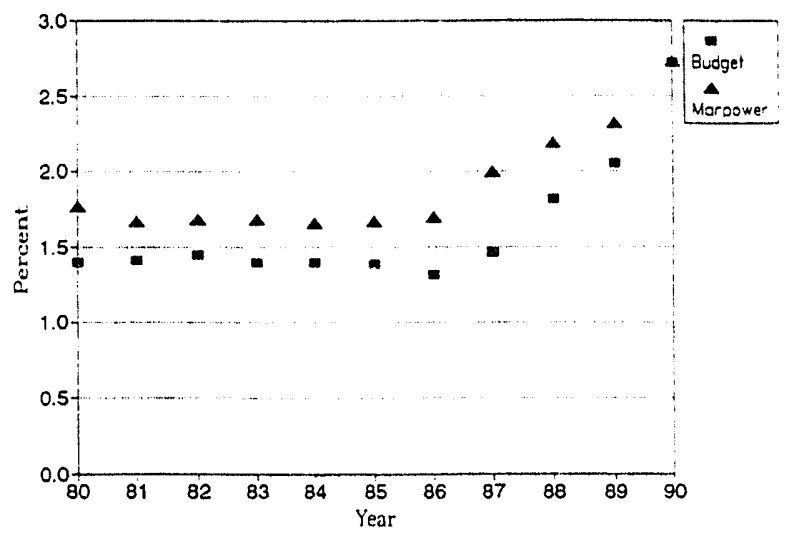

Figure 3. Safety budget and staff as a percentage of total facility operating budget and staff.

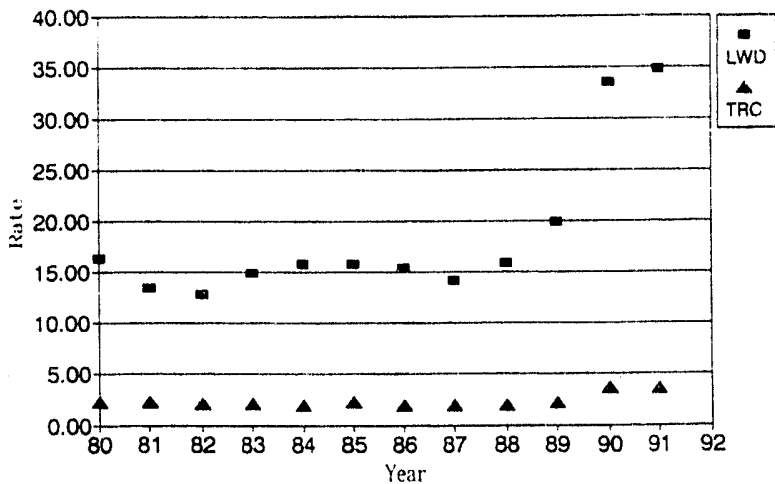

Figure 4. DOE contractor safety performance over 11 years. difference between production and research facilities, the two types reviewed in this study. As shown in these figures, both safety funding and accident experience have been stable during most of the 1980s. Recently (19881989), a changing safety culture within DOE has placed added emphasis on compliance with a resultant greater safety investment. This has resulted in a near doubling of the safety staff and costs at the various contractoroperated facilities.

A relationship between safety investment and accident loss has been proposed in the literature. Curves such as those shown in Fig. 5 have been published (1, 2 ) and presented at national safety conferences (3). The relationship shown between safety expenditure and accident costs is intuitively appealing; however, no data has been published to determine the true validity of this relationship. In Grose's Managing Risk: Systematic Loss Prevention for Executives (1), the focus of this relationship is on the total cost of loss prevention as the sum of investment and identifiable losses. The message is that risk extracts a cost: you can pay for it now (investment) or later (losses). Identifiable losses can never be totally eliminated, as you can only approach the zero loss asymptote. Continuing expenditure to preclude losses simply approaches the asymptote of infinite investment.

EG\&G, in its Risk Management Guide (2), presents the total cost as the sum of the safety investment and the residual accident cost, which still persists at some current level of investment. The resultant curve is the same as that of Grose. EG\&G believes that zero investment in safety results in

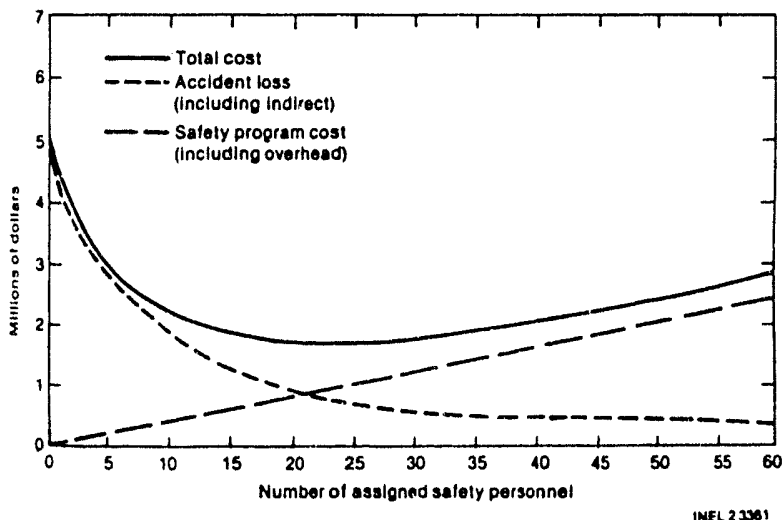

Figure 5. Theoretical relationship between safety investment and accident costs. 
maximum accident costs and that initial investments have the greatest impact, each increment thereafter yielding successively smaller returns. This view suggests that an optimum level of effort (program/ investment) exists and that above this level of safety effort, investments in safety are not matched by associated reductions in accident costs.

Sweginnis (4) uses a marginal cost concept, again with the same curve. $\mathrm{He}$ argues that investments that provide the greatest return per dollar should be given top priority. At low safety funding, small increases in safety program costs can result in large decreases in accident costs. The marginal cost concept illustrates that bigger safety programs are not necessarily better. This system is, perhaps, best used in determining priority of budgeting for the reduction of risks, i.e., funding those projects/programs that will provide the greatest reduction in risk.

\section{Sources of Data}

DOE annually publishes the Occupational Injury and Property Damage Summary (5), which lists lost workdays, reportable injury cases, property loss in dollars, and other accident statistics by contractor facility. The data in this report are of fairly uniform quality because of DOE regulations and report auditing. It may provide one of the best-quality accident summaries of operational experience available in the United States. OSHA does not administer or supervise the reporting of this injury data, and DOE contractor sites have not been subject to routine OSHA inspections. This creates some concern about reporting accuracy; however, DOE Order 5483.1A, "Occupational Safety and Health Program for DOE Contractor Employees at Government-Owned Contractor-Operated Facilities," does require compliance to OSHA reporting requirements. Occurrence reporting has been audited periodically at the various sites over the study period. OSHA evaluations have found no serious record-keeping problems in approximately half of the GOCO facilities reviewed. In any event, the data are generally selfconsistent, even if not entirely accurate in an absolute sense, which makes them useful for a comparison of the effectiveness of safety programs among the DOE contractor sites studied.

The cost of safety programs and safety efforts at the DOE facilities has not been followed as closely as the accident reporting. No firm guidelines exist as to what the safety funding should be. These costs have been estimated in cross-cut budget submittals, but this data is not very sound, as it is a projected estimate rather than actual costs and it is treated in different ways by the various DOE contractors. No budget category currently exists by which DOE can call out the actual cost of safety at the various sites. Each contractor does, of course, have a record of what was spent in any given year. However, each breaks up the safety effort differently and has individual differences of organization. On-site reviews with contractor personnel and site safety managers were used to sort out a comparable cost data set. The figures provided by these managers are believed to be accurate within $5 \%$.

Site and safety budgets were developed that included operating, manpower, and capital equipment dollars. Line item construction was not included in the cost figures studied, as this effort is sporadic and largely conducted by subcontractors. The reported facility personnel FTE (full time equivalent) count does not include construction workers or contract personnel. The disciplines of industrial safety, industrial hygiene, health physics, criticality safety, emergency preparation, bioassay, and fire protection were considered to form the core of the safety program as studied in this report. Safety costs include analytical costs of samples and measurements performed as part of the safety program and administrative support (clerical) costs. The costs and staffing of medical, environmental, hazardous material transportation, waste disposal, and fire fighters were not included.

The fiscal year runs from October 1 to September 31 and is the basis for the budget information used in this study. The accident reporting is done on an annual basis, from January 1 to December 31. In actual practice, most departments get budget authorizations late, and a comparison of fiscal year costs and annual year accident experience is felt to be satisfactory.

Only sites of more than 2000 employees were studied (Table 1), in an attempt to avoid situations in which a single long-term injury might seriously skew the statistics. The one exception, Pinellas, was included to provide a complete comparison of DOE's Defense Program facilities. 
Table 1. DOE contractor sites studied.

\begin{tabular}{llc}
\hline DOE facility & \multicolumn{1}{c}{ Location } & $\begin{array}{c}\text { Avg } \\
\text { employment* }\end{array}$ \\
\hline Argonne & Chicago, IL & 4160 \\
Brookhaven & Long Island, NY & 3180 \\
Fermilab & Chicago, IL & 2040 \\
Kansas City & Kansas City, MO & 6940 \\
LANL & Los Alamos, NM & 7530 \\
LBL & Berkeley, CA & 2640 \\
LLNL & Livermore, CA & 7770 \\
Mound & Miamisburg, OH & 2190 \\
ORNL & Oak Ridge, TN & 4581 \\
Pantex & Amarillo, TX & 2570 \\
Pinellas & Clearwater, FL & 1790 \\
Sandia & Albuquerque, NM & 7130 \\
Y-12 & Oak Ridge, TN & 6642 \\
\hline
\end{tabular}

\$980-1989.

These sites represent both research laboratory operations and production operations. Though each may do some of the other's type of operation, sites are generally managed for optimization of the predominate charter. Safety performance data from the two types of sites indicates that they are similar in performance even with their differing charters (see Fig. 6). The data plotted is the average for all DOE contractors sorted by the type of mission activity. Production and research can be seen to cross as the years pass. High and low values for the sites studied in each category overlap the averages plotted. Where service organizations were a

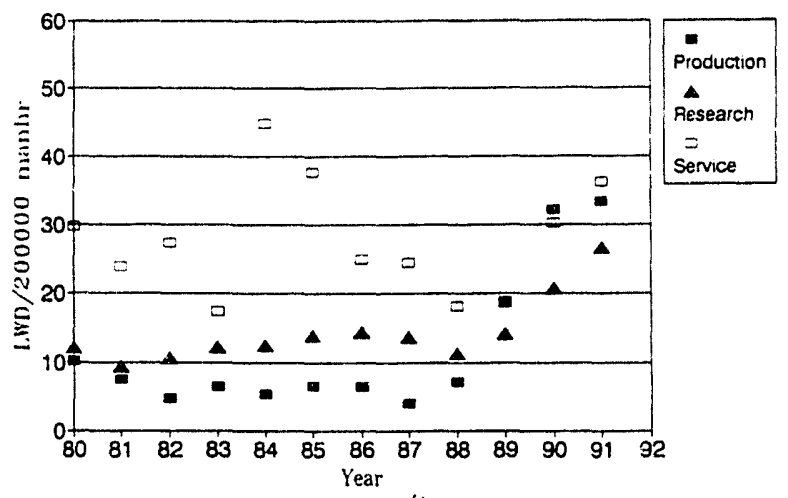

Figure 6. DOE contractor safety performance (LWD rate) by contractor type over 11 years. part of the managing contractor's site responsibility, these records have been integrated into the production or research figures for the 13 sites studied (see Appendix C for details).

Environmental costs are not included as they have changed so drastically over this time period. Also, environmental insult data is not yet reported in the same, self-consistent, manner as the accident data. Uniform measures of environmental impact have not been established to readily compare the consequences (i.e., costs) among the various DOE sites.

Emergency response costs (primarily site fire departments) are not included as these services are furnished in a variety of ways to the different sites. They also have little impact on the number of accidents recorded, though, of course they should play a strong role in limiting the severity of accidents and accident losses.

Though line managers are responsible for safety, and there are safety costs borne programmatically, this study focused on those costs identified as associated with a formal safety program and department. Programmatic safety costs, such as safety committees in line organizations, operational safety procedure development and reviews, and management walkthroughs are not included in the safety-cost figures as such expenditures are nearly impossible to estimate. In the early portion of this study report (1980-1984), such efforts were generally minimal. However, the last two years (1991-1992) have seen a large increase in programmatic efforts in safety as the DOE has focused on line management's responsibilities in safety. Safety assurance offices established in line organizations and the program's development of its own safety staff will make future data of the type gathered in this study much more difficult to acquire.

Most of the facilities in this study handle radioactive materials or utilize radiation-producing equipment, which results in radiation exposures to employees. Radiation doses for all DOE facilities are published annually in a summary report by the Office of Environment, Safety and Health (EH) (6). Using ICRP methodology, it is possible to estimate a potential health consequence due to cumulative radiation dose. Though these effects are not immediate and may be only calculational, various agencies have assigned a cost to them. The figure $\$ 1000.00$ per person-rem is recommended by the NRC and is used in this report.

Worker's compensation costs are also a consequence of a less-than-adequate safety control system. These costs are part of the total cost of accidents, even though they are generally accounted for in different ways than the majority of accident costs 
tracked by the DOE. Worker's compensation costs were obtained from loss control officers at most of the sites reviewed, but were not available at all sites. Some contractors changed insurance carriers during the period 1980-1990 and were unable to obtain data from earlier carriers; two others did not have the data available at all. In nearly all cases, the management of worker's compensation data and experience was separate from the safety organization. A number of factors may reduce the value of worker's compensation costs as a comparator of safety program performance. Various States have different laws as to what is covered, and different contractors define incidents as "work related" independently. There is also a difficulty in the payment of claims, which may be protracted over several years. The data presented here (Appendix C) is for actual costs/payments in the year listed and does not include administrative costs.

\section{Results}

Safety costs were used as the primary basis for comparison of safety investment, though other measures are plotted for the reader's review. Some departments may contract analytical work or have it done by other laboratories on site, but these costs are generally assigned to the safety department. Likewise, rather than staff for dosimetry, a company may contract out this service. The FTEs normally associated with this function would not appear in the safety head count of that company, but the costs of that effort will.

The percent of a company's budget invested in safety varied by a factor of 10 between the sites studied. The lost workday (LWD) rate was used as the primary indicator of safety experience. During site visits and interviews with the various safety managers, there was a greater expressed variation in the method of reporting total recordable cases (TRC) among the sites studied. LWD rate appeared to have more checks and balances (i.e., payroll, benefits, medical; a number of interested parties in addition to the safety department).

LWD rate varied by a factor of 10 on the average and by a factor of nearly 100 in individual years between the sites studied.

Losses for the sites studied here were all below, and some far below, the safety investment of these contractors, i.e., well to the right of the crossover noted in Fig. 5. This relationship is plotted as a function of the difference between investment and losses in Figs. 7 through 9. Figure 7 shows the average data for the years 1980 through 1989, which is little different from that of the early portion of this study (Fig. 8, 1980-1984), before any changes in reporting or safety emphasis were initiated. Two points, LANL and LINL, lie well to the right of the majority of the data. Both of these laboratories have traditionally conducted very comprehensive safety programs, providing their own analytical support and even conducting research programs in the various safety disciplines. Though these programs have contributed outstanding technical

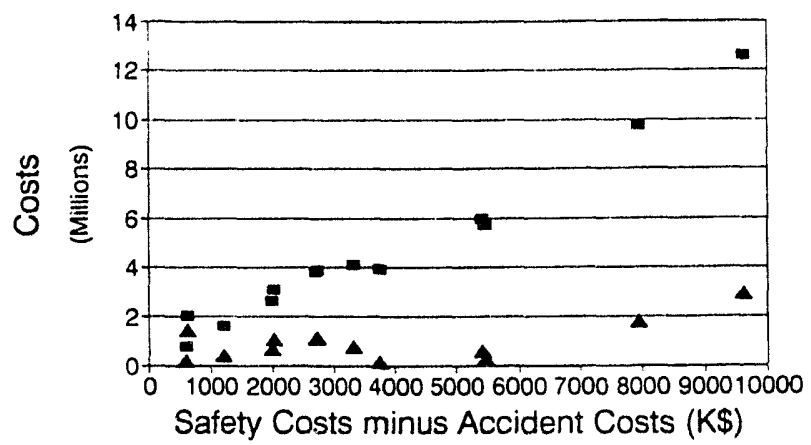

- Safety Costs $\Delta$ Accident losses

Figure 7. Safety costs minus accident costs for contractors studied, 1980-1989 average.

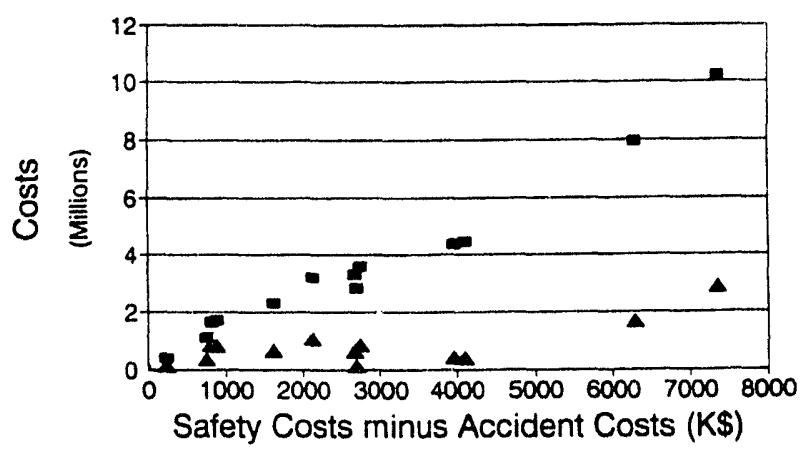

- Safety Costs A Accident losses

Figure 8. Safety costs minus accident costs for contractors studied, 1980-1984 average. 


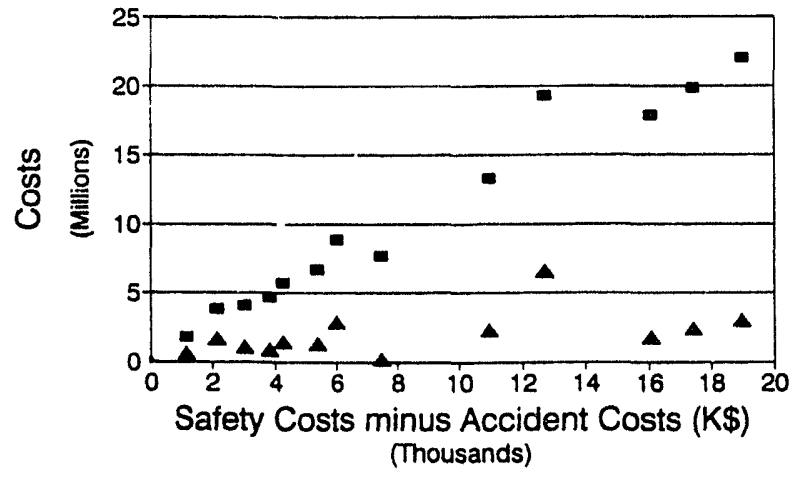

- Safety Costs A Accident losses

Figure 9. Safety costs minus accident costs for contractors studied, 1990.

support to national standards and policy development, they do not appear to have been any more effective in reducing accidents than less well developed programis.

Inclusion of the worker's compensation costs and a cost estimate for radiation dose changes the differentials only slightly; and only in the case of Brookhaven, for the 1980-1989 average, do the total accident costs exceed the safety costs. The 1990 data (Fig. 9) show a tendency for programs to move to the right as their funding has been increased (i.e., show a poorer return on investment). One program (Mound) reports a much lower accident cost for its safety investment than other sites spending comparable amounts. One might review this program to determine how it has been so effective or to determine whether accident reporting has the same accuracy as at other sites. Were it not for the rise in accident costs at the right-hand end of these curves, they would reflect well the theoretical predictions of the literature cited earlier.

The data used in all plots is summarized in Appendix B and given by individual site in Appendix C.

Figure 10 compares the LWD rate to the percent of a site's total budget invested in safety, averaged over the years 1980-1989, for the 13 sites included in this study. There is a clear but weak positive correlation between safety investment and safety performance. The regression line plotted (data in table B1) has an R-squared value of 0.26 and significant standard errors. Perhaps of most interest are those points furthest from the line. Mound has been pointed out previously for its low relative LWD rate, and on this chart, Brookhaven appears somewhat high for its relative funding position. The Brookhaven safety staff have conducted an extensive analysis of their reporting and performance.

A plot of LWD rate against safety staff, shown in Fig. 11, is similar, but the correlation is even weaker.

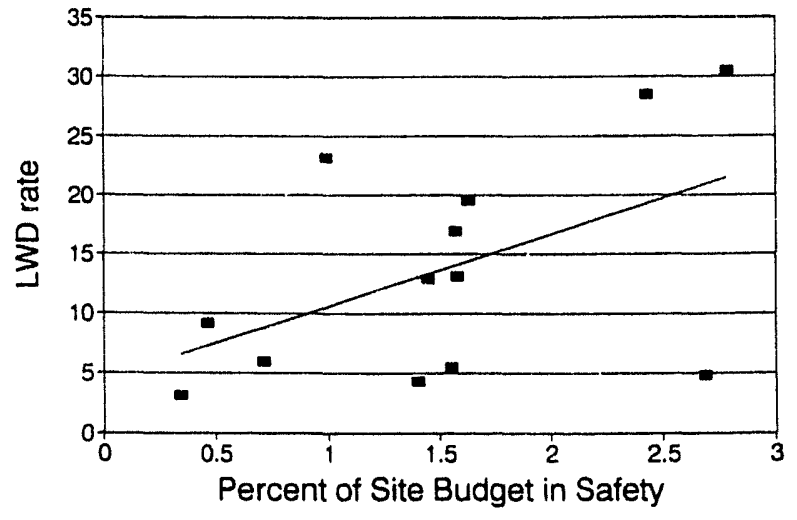

Figure 10. LWD rate compared to percent of site budget spent on safety, 1980-1989 average.

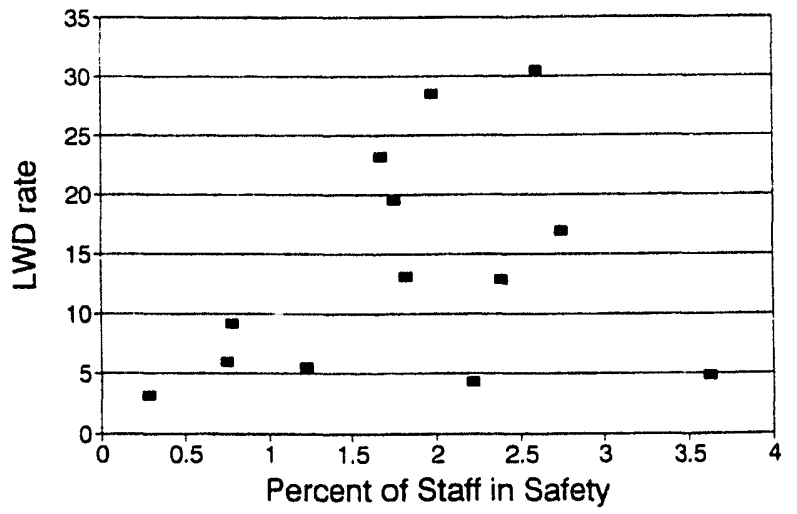

Figure 11. LWD rate compared to percent of site personnel committed full time to safety, 1980-1989 average.

Another way of looking at the manpower committed and lost is shown in Fig. 12. The two variables are relatively independent, with the regression line mainly flat between 1.5 and 2.5. However, the point at the extreme right (Fermilab) might bear review. Absolute values are shown in Fig. 13, where there is no correlation between the number of FTEs invested and the number lost (R-squared values near zero). Within the DOE complex, contractor safety staffs have a large number of functions that are not all related to reduction of lost-time injuries.

The data is even more scattered when comparing TRC to safety investment, as shown in Figs. 14 and 15 .

Figures 16 and 17 provide a more direct cost comparison. Both as a percentage of operation funds and in absolute dollars, the experience of the 13 contractor sites surveyed is that there is a weak positive correlation 


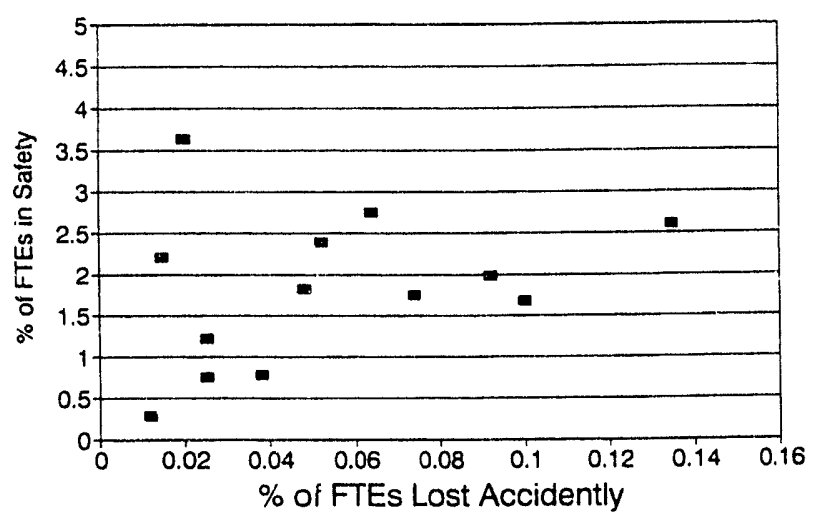

Figure 12. Percent of contractor staff in safety compared to the percent of staff lost accidentally per year, 1980 1989 average.

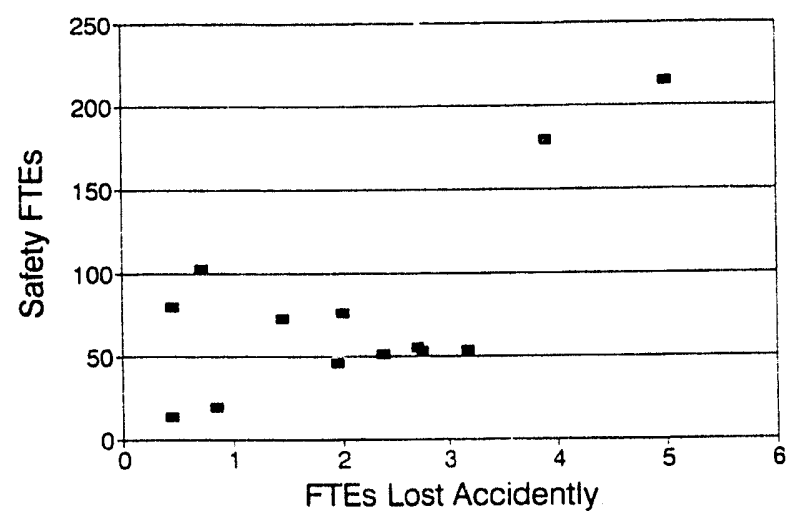

Figure 13. Average safety personnel compared to average lost manpower, 1980-1989 average.

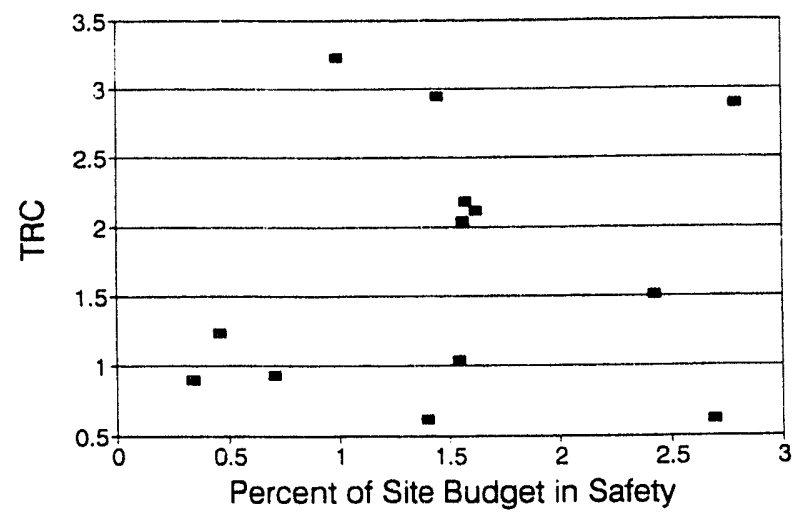

Figure 14. Total reportable case rate compared to percent of site budget spent on safety, 1980-1989 average.

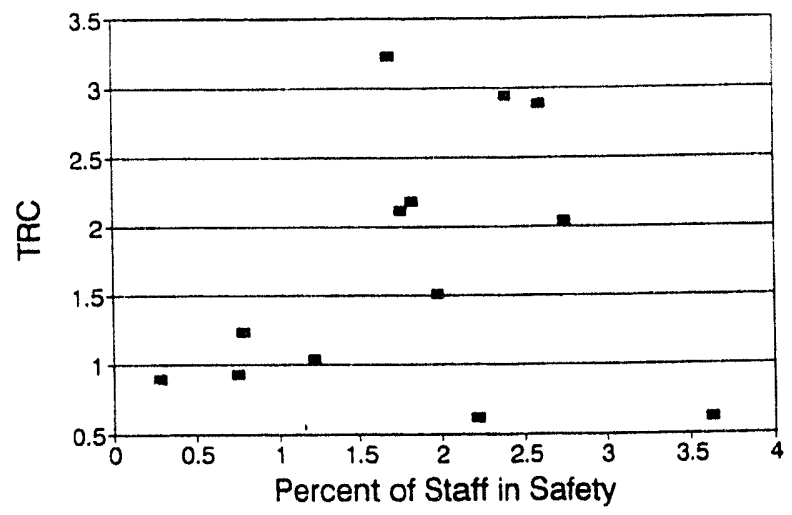

Figure 15. Total reportable case rate compared to percent of site personnel committed full time to safety, 1980-1989 average.

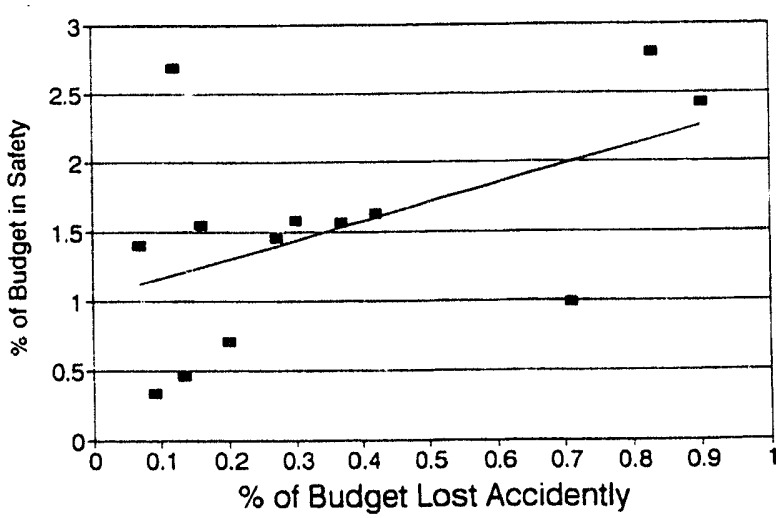

Figure 16. Percent of contractor budget invested in safety compared to percent of contractor budget lost through accident, 1980-1989 average.

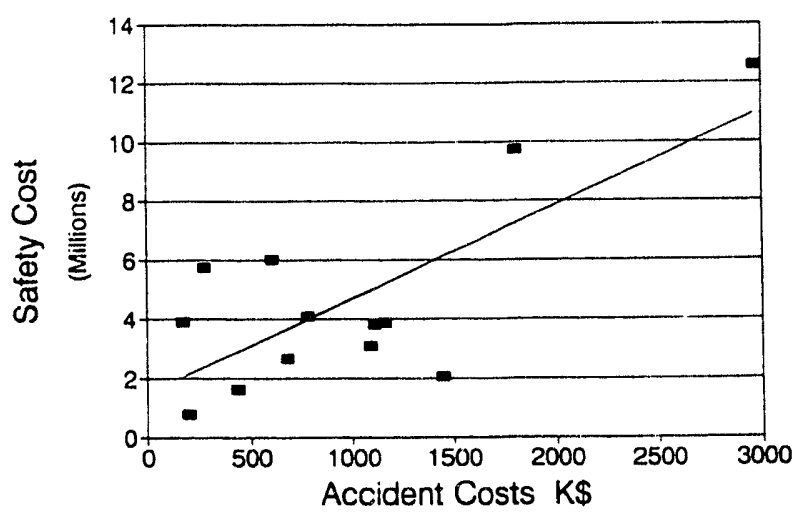

Figure 17. Average safety investment compared to average dollar loss, 1980-1989 average. 


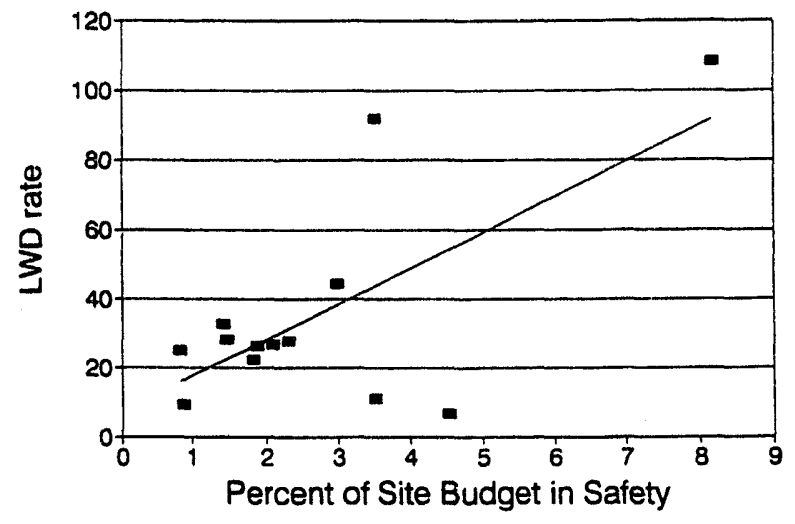

Figure 18. LWD rate compared to percent of site budget spent on safety, 1990.

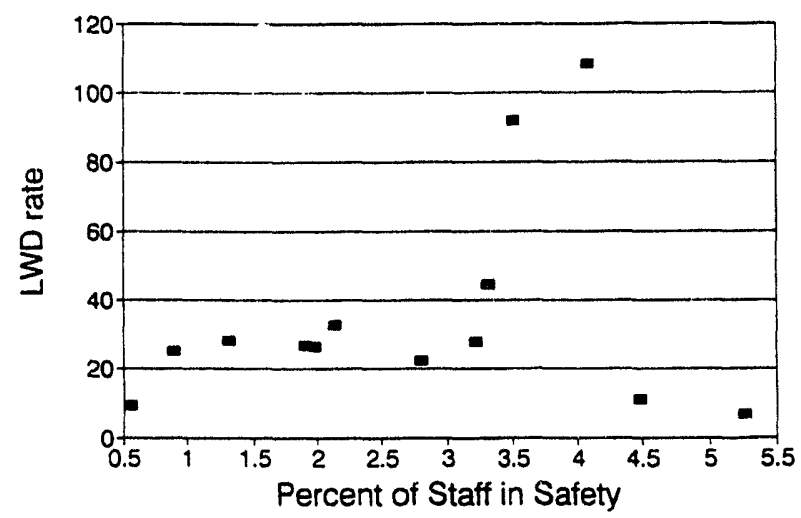

Figure 19. LWD rate compared to percent of site personnel committed full time to safety, 1990.

(R-squared values range from 0.25 to 0.56 ) between what is invested in a formal safety program and the loss experience of that company. The correlation shown in Fig. 17 is most likely driven by size rather than any dependent relationship. Though one would accept that large companies might both spend more on safety and lose more through accidents, one would not have anticipated that on a relative basis larger (better?) safety organizations would result in poorer safety performance.

Figures 18 through 24 show recent (1990) data, which are even more scattered. Though the LWD rate (Fig. 18) correlates positively to the percent of the site's budget spent on safety, this correlation is due almost entirely to one point at the extreme right (Pantex). The same is true of the relationship in Fig. 23, despite the R-squared value of 0.44 .

The data was compared in 5-year blocks, 1980 1984 and 1985-1989, to see whether practices or relationships were different during the study period.

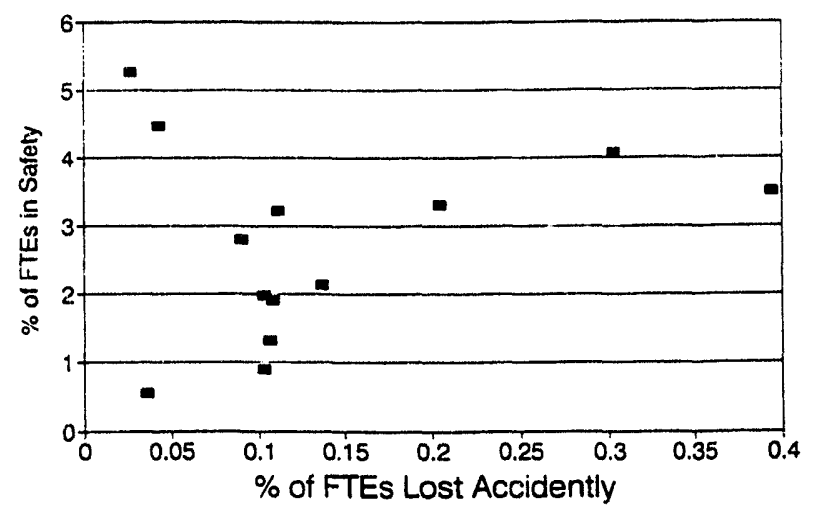

Figure 20. Percent of contractor staff in safety compared to the percent of staff lost accidentally per year, 1990 .

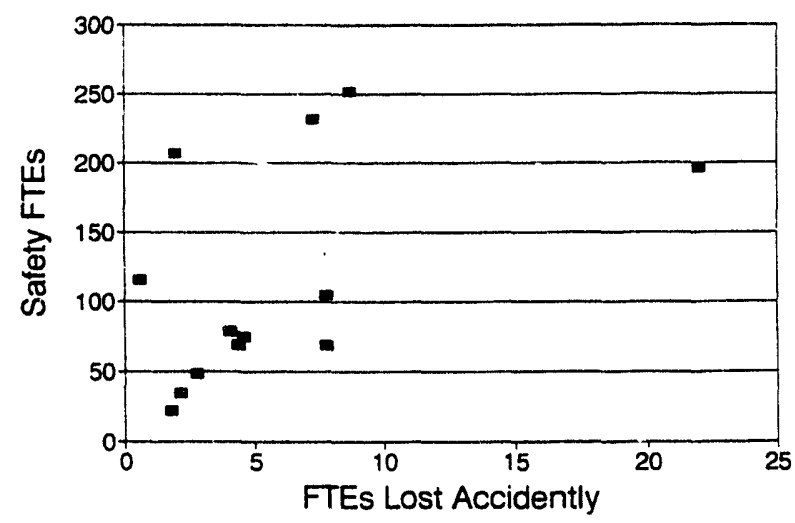

Figure 21. Safety personnel compared to lost manpower, 1990.

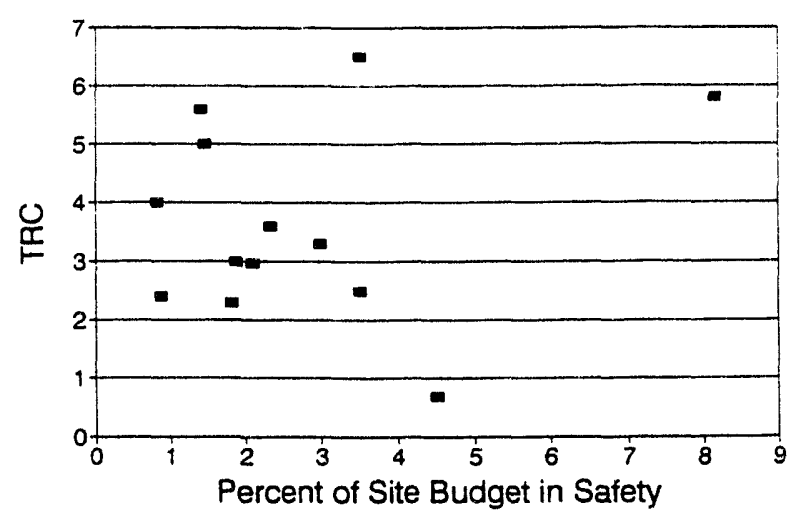

Figure 22. Total reportable case rate compared to percent of site budget spent on safety, 1990. 
As seen in Figs. 25 and 26, no clear difference from the overall average (Fig. 10) is obvious. The correlations are all positive but weak ( $R$-squared values of 0.23 , 0.26 , and 0.28 ).

Worker's compensation data, though less complete (11 of 13 sites available for 1990, fewer for earlier time periods), shows the same trends (Fig. 27). The greater the percentage of a site's operating budget that is devoted to a formal safety program, the greater the worker's compensation cost experience. Worker's compensation experience is not independent of the

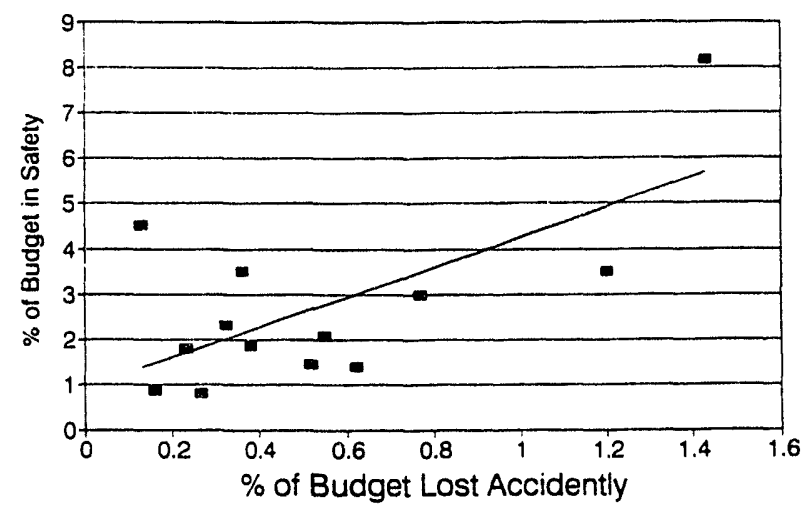

Figure 23. Percent of contractor budget invested in safety compared to percent of contractor budget lost through accident, 1990.

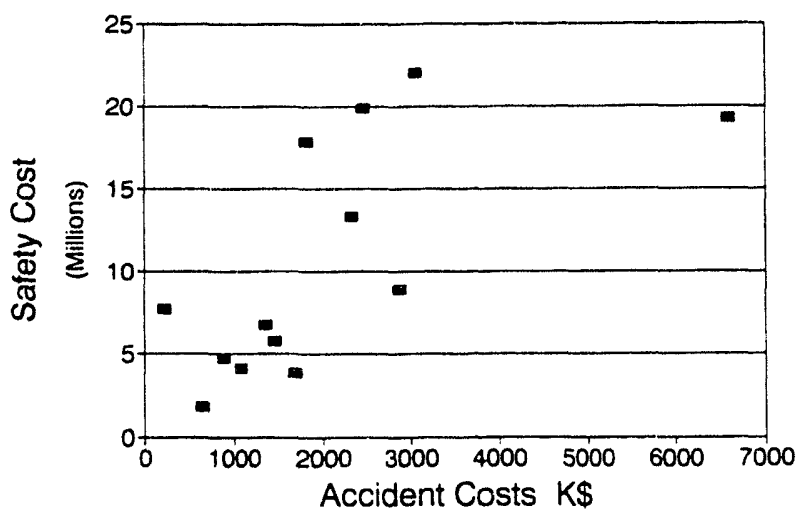

Figure 24. Safety investment compared to dollar loss, 1990. other data presented here; for example, higher LWD experience will result in higher worker's compensation. However, the worker's compensation expense is recorded and tracked independently, and, generally, by different organizations at a site, and so it gives a check on the other data presented. The total loss due to accidents, including the cost estimate for radiation dose and worker's compensation costs, is compared with the operating budget in Fig. 28. The relationship is more strongly dependent (R-squared value of 0.62 ) than any of the other comparisons.

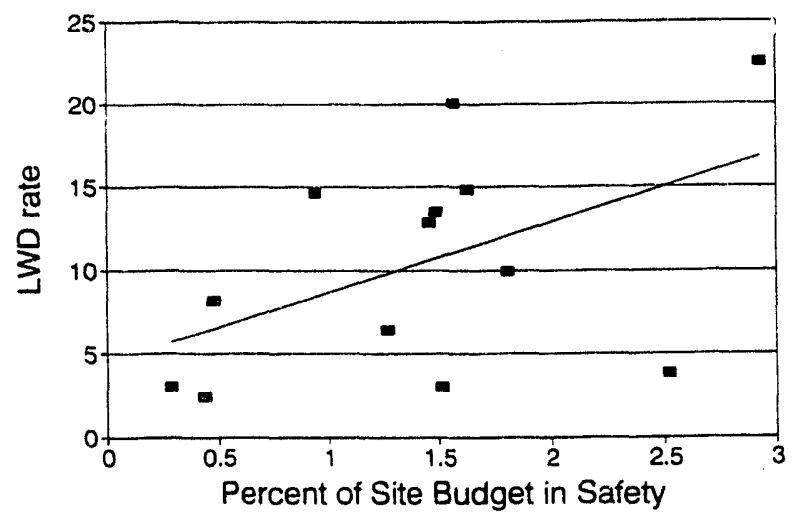

Figure 25. LWD rate compared to percent of site budget spent on safety, 1980-1984 average.

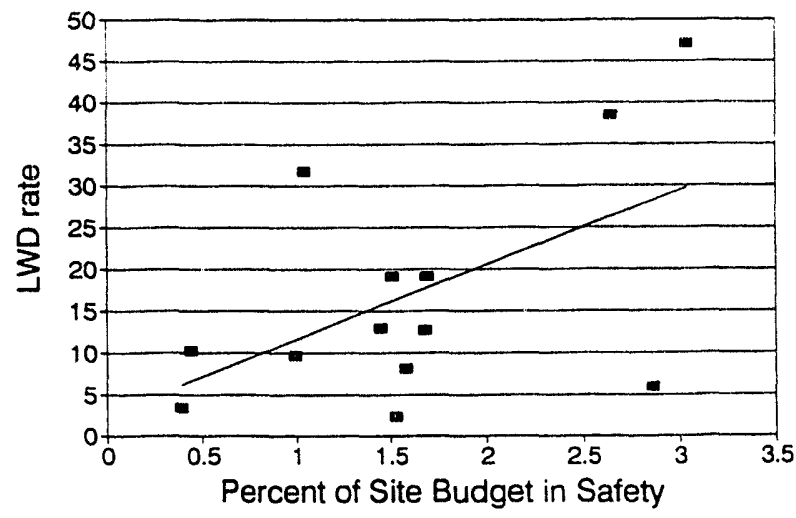

Figure 26. LWD rate compared to percent of site budget spent on safety, 1985-1989 average. 


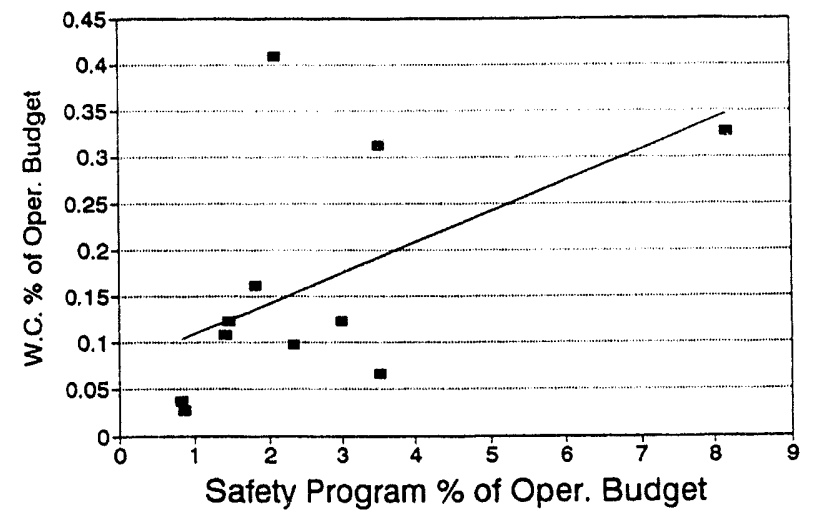

Figure 27. Worker's compensation cost dependency on safety program percent of operating budget, 1990.

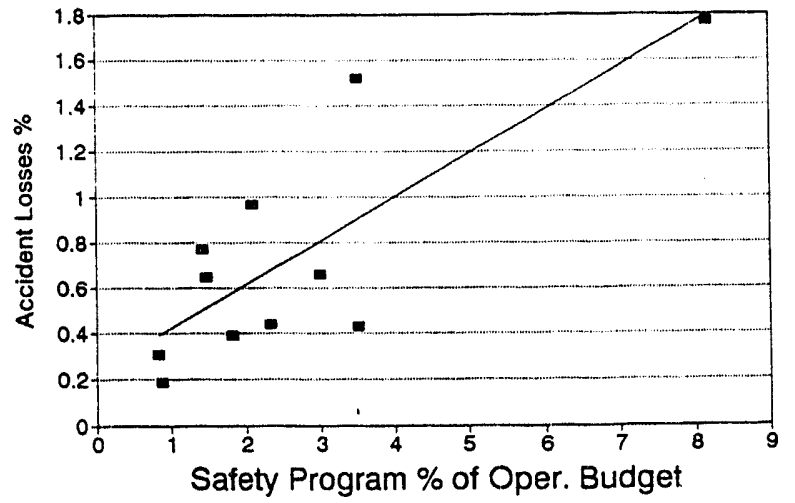

Figure 28. Total loss dependency on safety program, 1990.

\section{Discussion}

Though safety performance and safety investment each varied by a factor of 10 for the sites studied, no obvious cost-benefit relationship exists. There is a weak correlation that indicates that the greater the investment, the greater the loss, counter to popular safety literature. The range of data is, however, all located in one region of interest (i.e., facilities committing more to safety than they normally lose accidentally). Actual data from facilities/operations not traditionally providing such strong safety support might be instructive. Kolar (7) reports a much broader range of safety performance of DOE contractors than that exhibited by the limited sites of this study. Inclusion of those at the extremes of performance may provide more insight as to possible relationships to funding support.

Though operations vary at the various sites studied, there is no clear difference as to degree of hazard. Multidiscipline research laboratories have accident experience interwoven with more routine production facilities. There is also no obvious impact from such major events as a change of operating contractor (reported by 4 of the 13 facilities during the period covered) or the Tiger Team assessments. It may be only coincidence that sites have experienced greater injury rates following the Tiger Team work. Rather, the most dramatic changes resulted from changes of reporting practice (Brookhaven and Sandia) or employee attitudes (Pantex, following a layoff announcement).

In a Ph.D. thesis, Shafai-Sahrai (8) reported on factors that might explain the differences in occupational accident experience of similar facilities.
Factors that he considered were: (1) top management's support and involvement in safety, (2) formal education level of workers, (3) age of the employees, (4) company recreational programs, (5) promoting safety through the employee's family, (6) safety rules, (7) marital status of the workers, (8) worker's length of service in a company, (9) company age, (10) accident record-keeping system, (11) first-line supervisor's relative span of control, (12) relative age of production machinery and equipment, (13) physical workplace conditions, (14) safety devices and controls on machinery, and (15) safety committees. Safety investment was not a specific factor of his study. Several factors were found supportive of improved safety, top management involvement and supervisor span of control being the strongest. Quality and quantity of safety rules and safety committees (two popular DOE approaches) did not appear to be significant factors in the attainment of a good safety performance record. Interestingly, ShafaiSahrai found that those companies with the better record-keeping systems had considerably lower work injury rates. Intangibles such as employee morale and public perception were not included in his study, nor were they considered in this report.

Radiation safety costs were a significant factor in many of the facilities studied. From 5 to $50 \%$ of the safety budget is spent in this area, which contributes little to immediate accident losses. Lawsuits involving radiation (or anything else) have created costs that are not included here. Lost time due to radiation injury is practically nonexistent. In general, costs associated with 


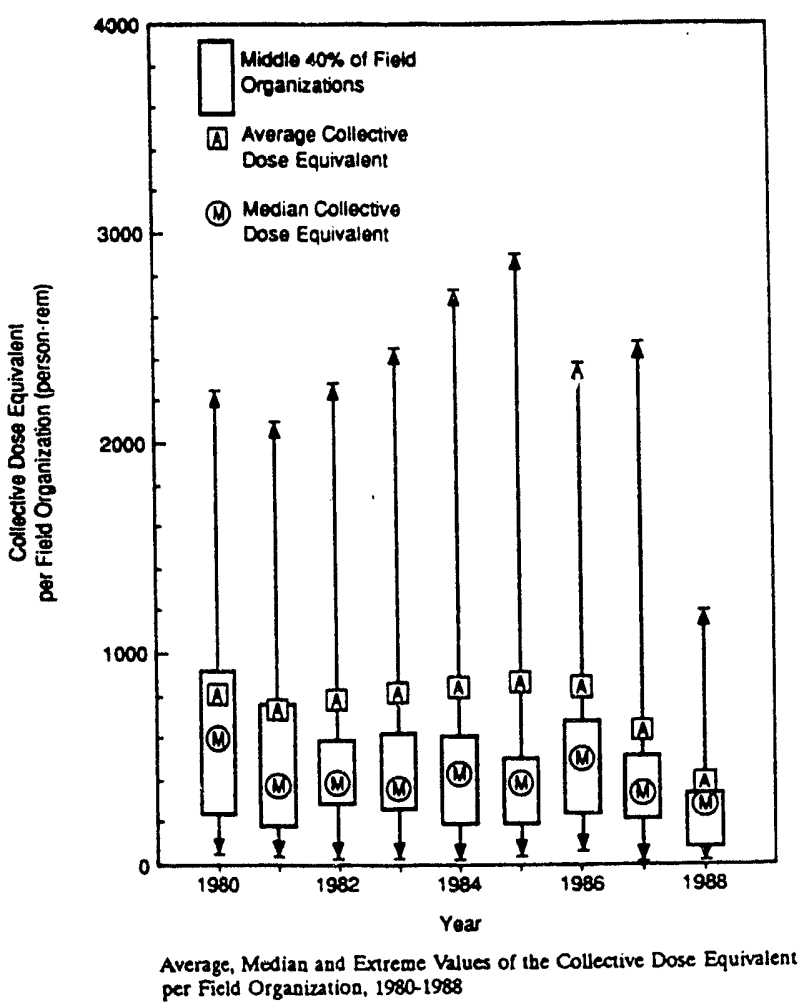

Figure 29. Radiation exposure of DOE contractor employees. (Reproduced from Ref. 9.)

incidents, cleanup, investigation, and support are included in this study. Radiation exposure among DOE workers lias been relatively stable at a level far below regulatory limits throughout the period covered (Fig. 29, from Ref. 9). Using the NRC value of $\$ 1000$ per person-rem in the time period 1980-1989, some facilities would show 30 to $40 \%$ of their losses associated with radiation-dose-related consequences. By 1990, dose reduction efforts had reduced this impact to $1-5 \%$ of the total loss for even those facilities having the highest dose totals. Additional effort in this area is unlikely to improve DOE's safety performance.

Though most of the sites studied had worker's compensation costs on the order of $0.1 \%$, two showed costs above $1 \%$ (Brookhaven and Pantex).

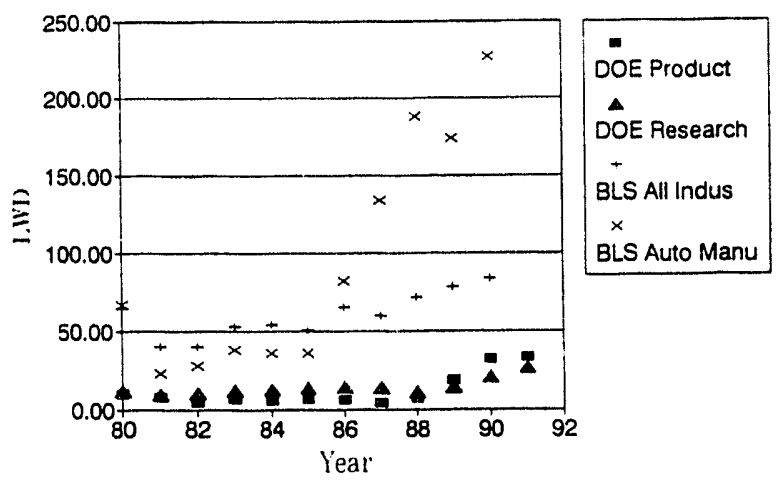

Figure 30. LWD rate comparison between DOE and generai industry.

The general rise in safety performance indicators (decline in safety) among DOE contractors is somewhat disturbing. The comparison to general industry (Bureau of Labor Statistics) shown in Fig. 30 indicates this rise to be a reflection of a nationwide trend and considerably less than that experienced by some other industries. This rise may reflect a greater awareness of reporting requirements or a general public concern with workplace safety. It may also be driven by things such as repetitive motion injuries, which were not recognized as workplace related in earlier years, or by an increased focus on paperwork, which drives the safety professional from the field to his desk.

In general, despite an increased focus on safety and considerably increased investment in safety, both in absolute dollars and as a percentage of facility operating budget, nothing has changed. The same trends exist in the 1980-1984, 1985-1989, and 1990 data; and safety performance has not changed appreciably.

Reviewing the trends plotted and performance averages of the 13 facilities, two safety goals appear possible: (1) lose less than $1 \%$ of your operating budget annually, and (2) lose less than $0.1 \%$ of your work force to lost time injuries annually. It also appears that $2 \%$ of the operating budget invested in safety provides an adequate loss control program.

\section{Conclusions}

The traditionally accepted, and intuitively appealing, relationship between safety investment and safety performance is not supported in this study. 


\section{Acknowledgments}

I express my sincere appreciation to the safety and budget managers at the sites studied for their time and efforts in gathering the data reported here and their review of this work: Pat Bean in the DOE/HQ Budget Office, Bill Burnett and Sue Henderson at Sandia National Laboratories, John Burr and Chuck Churchwell at Pantex, Bob Casey and Lynn Kalback at Brookhaven, Jack Izzo at LBL, Connie Mack at LLNL,
Ginny McCauley and Rick Hagan at Pinellas, W. Millet with Management Information Systems at INEL, Rich Orr and Don Cossairt at Fermilab, John Puckett and Ron Stafford at LANL, Jocelyn Richardson and Dan Stoltz at the Kansas City Plant, Jerry Robertson and Mary Ann Groh at Y-12, Tom Row and Sewell Brown at ORNL, Warren Smith and Jamie Landrum at Mound, and Bob Wynveen at Argonne.

\section{References}

1. V. L. Grose, Managing Risk: Systematic Loss Prevention for Executives (Prentice-Hall, Englewood Cliffs, NJ, 1987), Figure 28.2, "Pay Now or Pay Later" curve.

2. G. J. Briscoe, Risk Management Guide, EG\&G Idaho, Inc., Idaho Falls, ID, DOE-76-45/11, SSDC-11, Revision 1 (1982), Figure 7, "Total accident costs ..."

3. G. J. Briscoe, "Management Safety Assurance," Idaho National Engineering Laboratory, presented at the 10th International System Safety Conference, Dallas, TX, July 18-22, 1991.

4. R. W. Sweginnis, "The Application of Several General Management Concepts to Specific System Safety Management Issues," University of Southem California, presented at the 10th International System Safety Conference, Dallas, TX, July 18-22, 1991.

5. Occupational Injury and Property Damage Summary, U.S. Department of Energy, Office of the Deputy Assistant Secretary for Safety and Quality Assurance, prepared by EG\&G Idaho, Inc., Idaho Falls, ID. This report is published annually; its former name, Injury and Property Damage Summary, was changed to the current name in 1989.

6. Radiation Exposures for DOE and DOE Contractor Employees; Thirteenth Annual Report (February 1982) through the Twenty-third Annual Report (December 1992); U.S. Department of Energy, Assistant Secretary for Environment, Safety, and Health, Office of Health.

7. O. C. Kolar, "Determination of the Effectiveness and Proper Funding Level of Safety Programs," Annual Technology Review, Lawrence Livermore National Laboratory, Livermore, CA, UCRL-50007-87 (1987).

8. Y. Shafai-Sahrai, An Inquiry into Factors that Might Explain Differences in Occupational Accident Experience of Similar Size Firms in the Same Industry, Ph.D. thesis, Michigan State University, East Lansing, MI (1971).

9. Twenty-first Annual Report, Radiation Exposures for DOE and DOE Contractor Employees - 1988, U.S. Department of Energy, Assistant Secretary for Environment, Safety, and Health, Office of Health, DOE/EH0171P (1990). 


\section{Appendix A Explanation of Terms}

Full-time equivalent (FTE) is the number of personnel employed over a year. 2000 man-hours worked = 1 FTE; 50 weeks, 40 hours per week.

Total recordable cases (TRC) are those cases involving an occupational injury or illness that requires medical care; first aid cases are not included.

Lost workdays (LWD) are those days that the employee would have worked, but could not because of occupational injury or illness. LWC is the number of lost workday cases. The incident rate equals the number of injuries times 200,000 divided by the total hou $s$ worked by all employees during the time period covered, a rate for 100 full-time employees. The LWD rate is thus the number of lost workdays for 200,000 employee-hours worked.

The "accidental dollar loss estimate" is adapted from an EG\&G technique of "cost index," published in their annual Occupational Injury and Property Damage Summary (5). A loss value of $\$ 1,000,000.00$ is assigned for each fatality, $\$ 2,000.00$ is assigned for each reportable case and each lost workday case, $\$ 1,000.00$ is counted for each lost workday, and a value of $\$ 10,000.00$ is attributed to each type A or B incident. These added costs are attributed to the costs of incident investigation, record keeping, management time, etc. Fire and nonfire property losses are as reported by contractors to the DOE data base in Idaho. No implication as to the value of human life is made by these figures; they serve only for comparison of contractor safety experience. 


\section{Appendix B \\ Data Summary Tables}

The safety performance of security forces was included in facility figures until it was established as a separate reporting category with DOE in 1986 . Some sites did not immediately separate the security force numbers out of the general site population; these exceptions are noted in the appendix. The numbers affected were relatively small (<5\%) and have not been corrected back into the totals. The injury experience of plant support functions, i.e., gardeners, janitors, and crafts, was separated at some sites in the late 1980s. These were added back into the totals to maintain comparability. Only LANL has traditionally contracted this function out to another company. These records for LANL are therefore separated and not included in this study.

Some values have been multiplied by 10 to plot them on the same scale as others for comparison.

Table B1. Data summary from all sites.

Table B2. DOE LWD performance compared with that of general industry (Bureau of Labor Statistics).

Table B3. Regression analysis output for various comparisons. 
Table B1. Summary of data from all sites.

Data Summary

\begin{tabular}{|c|c|c|c|c|c|c|c|c|}
\hline Contractor & $\begin{array}{c}\text { TRC r } \\
1980-84\end{array}$ & $\begin{array}{c}\text { TRC r } \\
1985-89\end{array}$ & $\begin{array}{c}\text { TRC r } \\
1980-89\end{array}$ & $\begin{array}{l}\text { TRC r } \\
1990\end{array}$ & $\begin{array}{c}\text { LWD r } \\
1980-84\end{array}$ & $\begin{array}{c}\text { LWD r } \\
1985-89\end{array}$ & $\begin{array}{c}\text { LWD r } \\
1980-89\end{array}$ & $\begin{array}{l}\text { LWD r } \\
1990\end{array}$ \\
\hline Argonne & 2.06 & 2.30 & 2.18 & 3.00 & 13.46 & 12.76 & 13.11 & 26.40 \\
\hline Brookhaven & 2.12 & 4.34 & 3.23 & 5.60 & 14.60 & 31.76 & 23.18 & 32.70 \\
\hline Fermilab & 2.34 & 3.44 & 2.89 & 3.30 & 22.52 & 38.46 & 30.49 & 44.60 \\
\hline Kansas City & 0.96 & 0.84 & 0.90 & 2.40 & 2.98 & 3.30 & 3.14 & 9.40 \\
\hline LANL & 2.00 & 3.90 & 2.95 & 3.60 & 12.82 & 12.96 & 12.89 & 28.00 \\
\hline LBL & 1.84 & 2.41 & 2.12 & 2.97 & 20.08 & 19.05 & 19.56 & 27.04 \\
\hline LLNL & 2.34 & 1.74 & 2.04 & 2.30 & 14.84 & 19.05 & 16.95 & 22.42 \\
\hline Mound & 0.62 & 0.62 & 0.62 & 0.70 & 3.78 & 5.92 & 4.85 & 6.80 \\
\hline ORNL & 0.78 & 0.46 & 0.62 & 2.50 & 6.42 & 2.30 & 4.36 & 11.00 \\
\hline Pantex & 1.42 & 1.60 & 1.51 & 5.80 & 9.94 & 47.10 & 28.52 & 108.30 \\
\hline Pinellas & 0.32 & 1.54 & 0.93 & 5.00 & 2.40 & 9.62 & 6.01 & 28.10 \\
\hline Sandia & 1.26 & 1.22 & 1.24 & 4.00 & 8.18 & 10.28 & 9.23 & 25.10 \\
\hline$Y-12$ & 1.00 & 1.08 & 1.04 & 6.50 & 3.02 & 8.12 & 5.57 & 92.00 \\
\hline Average & 1.47 & 1.96 & 1.71 & 3.67 & 10.39 & 16.98 & 13.68 & 35.5 \\
\hline
\end{tabular}




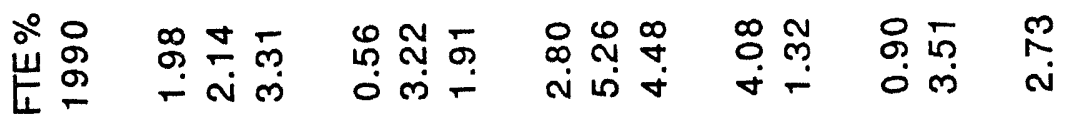

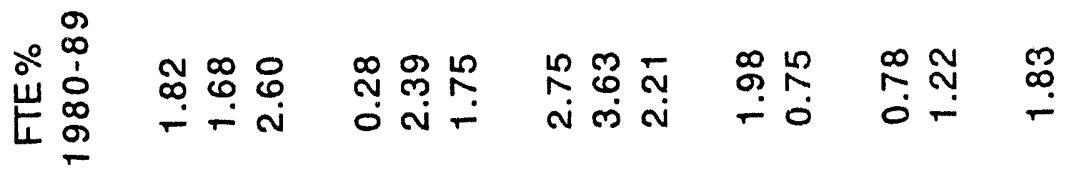

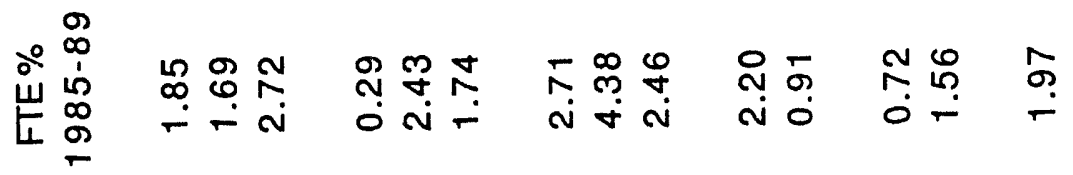

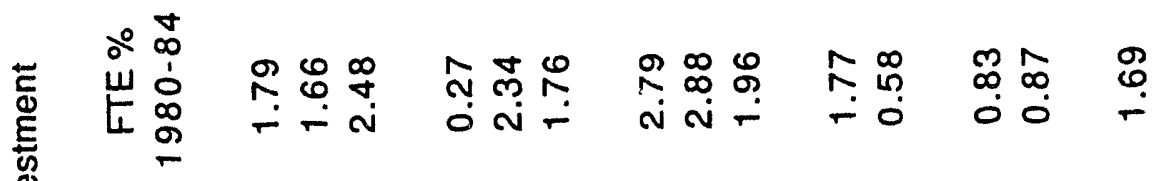

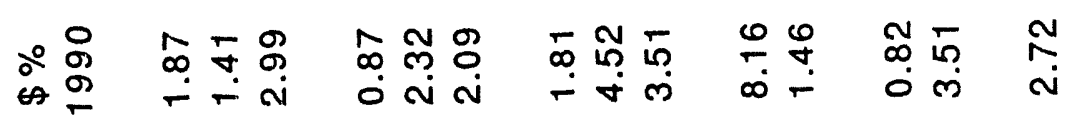

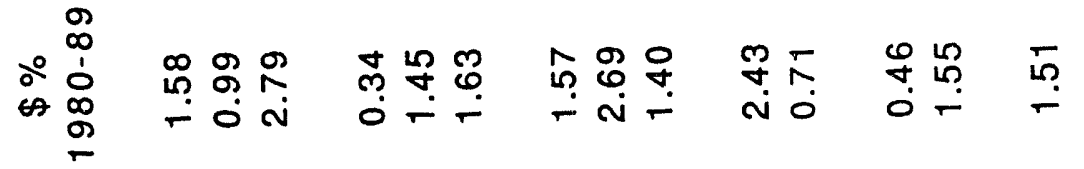

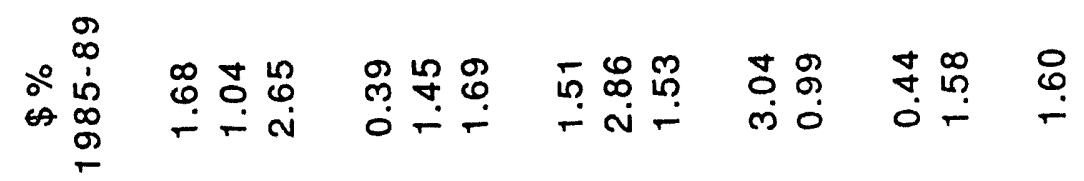

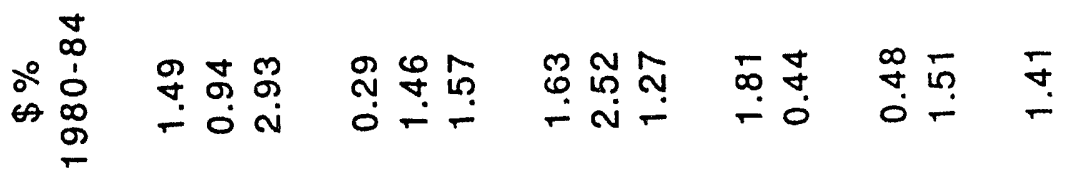

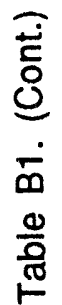

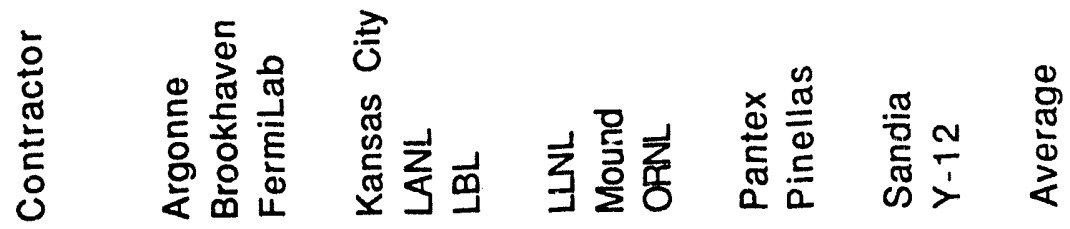


Table B1. (Cont.)

\begin{tabular}{|c|c|c|c|c|c|c|}
\hline Contractor & $\begin{array}{c}\text { 1980-89 } \\
\text { Safety } \\
\text { FTE }\end{array}$ & $\begin{array}{l}1990 \\
\text { Safety } \\
\text { FTE }\end{array}$ & $\begin{array}{c}\text { 1980-89 } \\
\text { FTEs } \\
\text { Lost }\end{array}$ & $\begin{array}{c}1980-89 \\
\% \text { FTE } \\
\text { Lost }\end{array}$ & $\begin{array}{l}1990 \\
\text { FTEs } \\
\text { Lost }\end{array}$ & $\begin{array}{l}1990 \\
\% \text { FTE } \\
\text { Lost }\end{array}$ \\
\hline Argonne & 75.60 & 79 & 2.00 & 0.05 & 4.10 & 0.103 \\
\hline Brookhaven & 53.30 & 69 & 3.18 & 0.10 & 4.40 & 0.137 \\
\hline FermiLab & 52.95 & 75 & 2.75 & 0.14 & 4.60 & 0.205 \\
\hline Kansas City & 19.50 & 35 & 0.84 & 0.01 & 2.20 & 0.036 \\
\hline LANL & 179.50 & 252 & 3.90 & 0.05 & 8.70 & 0.111 \\
\hline LBL & 46.10 & 49 & 1.95 & 0.07 & 2.80 & 0.108 \\
\hline LLNL & 214.49 & 232 & 5.00 & 0.06 & 7.30 & 0.090 \\
\hline Mound & 79.40 & 116 & 0.45 & 0.02 & 0.60 & 0.027 \\
\hline ORNL & 102.50 & 207 & 0.71 & 0.02 & 2.00 & 0.043 \\
\hline Pantex & 51.20 & 105 & 2.37 & 0.09 & 7.80 & 0.303 \\
\hline Pinellas & 13.30 & 22 & 0.44 & 0.03 & 1.80 & 0.106 \\
\hline Sandia & 55.20 & 69 & 2.70 & 0.04 & 7.80 & 0.103 \\
\hline$Y-12$ & 72.50 & 196 & 1.46 & 0.03 & 22.00 & 0.394 \\
\hline Average & 78.12 & 115.85 & 2.13 & 0.05 & 5.85 & 0.14 \\
\hline
\end{tabular}


Table B1. (Cont.)

\begin{tabular}{|c|c|c|c|c|c|c|c|}
\hline Contractor & $\begin{array}{c}1980-89 \\
\text { Site Budget } \\
M \$\end{array}$ & $\begin{array}{c}1980-89 \\
\text { Safety } \\
\mathrm{K} \$\end{array}$ & $\begin{array}{c}1980-89 \\
\text { Safety } \\
\$ \%\end{array}$ & $\begin{array}{c}1980-89 \\
\text { Lost } \\
K \$\end{array}$ & $\begin{array}{c}1980-89 \\
\% \text { of Site } \\
\text { Oper. } \$ \text { Lost }\end{array}$ & $\begin{array}{c}1980-89 \\
S \$-A \$ \\
K \$\end{array}$ & $\begin{array}{c}1980-89 \\
\text { (S\$-A } \$) \% \\
\text { Site Budget }\end{array}$ \\
\hline Argonne & $\$ 260$ & $\$ 4,110$ & 1.58 & $\$ 786$ & 0.30 & $\$ 3,324$ & 1.28 \\
\hline Brookhaven & $\$ 205$ & $\$ 2,050$ & 0.99 & $\$ 1,452$ & 0.71 & $\$ 598$ & 0.29 \\
\hline Fermilab & $\$ 141$ & $\$ 3,890$ & 2.79 & $\$ 1,165$ & 0.83 & $\$ 2,725$ & 1.94 \\
\hline Kansas City & $\$ 473$ & $\$ 1,640$ & 0.34 & $\$ 439$ & 0.09 & $\$ 1,201$ & 0.25 \\
\hline LANL & $\$ 668$ & $\$ 9,750$ & 1.45 & $\$ 1,810$ & 0.27 & $\$ 7,940$ & 1.19 \\
\hline LBL & $\$ 162$ & $\$ 2,660$ & 1.63 & $\$ 680$ & 0.42 & $\$ 1,980$ & 1.22 \\
\hline LLNL & $\$ 800$ & $\$ 12,590$ & 1.57 & $\$ 2,967$ & 0.37 & $\$ 9,623$ & 1.20 \\
\hline Mound & $\$ 145$ & $\$ 3,930$ & 2.69 & $\$ 176$ & 0.12 & $\$ 3,754$ & 2.59 \\
\hline ORNL & $\$ 404$ & $\$ 5,750$ & 1.40 & $\$ 280$ & 0.07 & $\$ 5,470$ & 1.35 \\
\hline Pantex & $\$ 121$ & $\$ 3,107$ & 2.43 & $\$ 1,089$ & 0.90 & $\$ 2,018$ & 1.67 \\
\hline Pinellas & $\$ 102$ & $\$ 780$ & 0.71 & $\$ 204$ & 0.20 & $\$ 576$ & 0.57 \\
\hline Sandia & $\$ 836$ & $\$ 3,820$ & 0.46 & $\$ 1,113$ & 0.13 & $\$ 2,707$ & 0.32 \\
\hline$Y-12$ & $\$ 376$ & $\$ 6,010$ & 1.55 & $\$ 607$ & 0.16 & $\$ 5,403$ & 1.44 \\
\hline Average & $\$ 335$ & $\$ 4,622$ & 1.51 & $\$ 982$ & 0.35 & $\$ 3,640$ & 0.90 \\
\hline
\end{tabular}


Table B1. (Cont.)

$\begin{array}{cccccccc} & 1990 & 1990 & 1990 & 1990 & 1990 & 1990 & 1990 \\ \text { Contractor } & \text { Site Budget } & \text { Safety } & \text { Safety } & \text { Accident } & \% \text { of Site } & \text { S\$-A } \$ & (S \$-A \$) \% \\ & M \$ & M \$ & \$ \% & M \$ & \text { Oper. } \$ \text { Lost } & K \$ & \text { Site Budget }\end{array}$

$\begin{array}{lrrrrrrr}\text { Argonne } & \$ 361 & 6.74 & 1.87 & \$ 1.37 & 0.38 & \$ 5,371 & 1.49 \\ \text { Brookhaven } & \$ 271 & 3.82 & 1.41 & \$ 1.69 & 0.62 & \$ 2,126 & 0.78 \\ \text { FermiLab } & \$ 191 & 5.73 & 2.99 & \$ 1.48 & 0.77 & \$ 4,255 & 2.22 \\ & & & & & & & \\ \text { Kansas City } & \$ 541 & 4.71 & 0.87 & \$ 0.89 & 0.16 & \$ 3,824 & 0.71 \\ \text { LANL } & \$ 950 & 22.02 & 2.32 & \$ 3.06 & 0.32 & \$ 18,954 & 2.00 \\ \text { LBL } & \$ 196 & 4.09 & 2.09 & \$ 1.08 & 0.55 & \$ 3,008 & 1.53 \\ & & & & & & & \\ \text { LLNL } & \$ 1,071 & 19.89 & 1.81 & \$ 2.46 & 0.23 & \$ 17,428 & 1.63 \\ \text { Mound } & \$ 170 & 7.69 & 4.52 & \$ 0.23 & 0.13 & \$ 7,465 & 4.38 \\ \text { ORNL } & \$ 510 & 17.89 & 3.51 & \$ 1.83 & 0.36 & \$ 16,063 & 3.15 \\ \text { Pantex } & \$ 163 & 13.29 & 8.16 & \$ 2.33 & 1.43 & \$ 10,964 & 6.73 \\ \text { Pinellas } & \$ 124 & 1.80 & 1.46 & \$ 0.65 & 0.52 & \$ 1,153 & 0.93 \\ & & & & & & & \\ \text { Sandia } & \$ 1,086 & 8.90 & 0.82 & \$ 2.88 & 0.27 & \$ 6,014 & 0.55 \\ \text { Y-12 } & \$ 550 & 19.31 & 3.51 & \$ 6.60 & 1.20 & \$ 12,710 & 2.31 \\ & & & & & & & \end{array}$


Table B1. (Cont.)

\begin{tabular}{|c|c|c|c|c|c|c|c|}
\hline \multirow[b]{2}{*}{ Contractor } & \multirow{2}{*}{$\begin{array}{c}1980-84 \\
\text { Safety } \\
M \$\end{array}$} & \multirow{2}{*}{$\begin{array}{c}1980-84 \\
\text { Accident } \\
M \$\end{array}$} & \multirow{2}{*}{$\begin{array}{c}1980-84 \\
S \$-A \$ \\
K \$\end{array}$} & \multicolumn{2}{|c|}{ Person*Rem } & \multicolumn{2}{|c|}{ Worker's Comp } \\
\hline & & & & $1980-89$ & 1990 & $\begin{array}{c}1980-89 \\
K \$\end{array}$ & 1990 \\
\hline Argonne & $\$ 3.60$ & $\$ 0.86$ & $\$ 2,740$ & 118 & 64 & N/A & $\$ 509.0$ \\
\hline Brookhaven & $\$ 1.66$ & $\$ 0.85$ & $\$ 806$ & 203 & 91 & $\$ 433.7$ & $\$ 294.0$ \\
\hline FermiLab & $\$ 3.31$ & $\$ 0.64$ & $\$ 2,671$ & 85 & 35 & $\$ 234.8$ & $(\$ 245.6)$ \\
\hline Kansas City & $\$ 1.13$ & $\$ 0.38$ & $\$ 754$ & 3 & 0 & $\$ 104.5$ & $\$ 146.0$ \\
\hline LANL & $\$ 7.96$ & $\$ 1.67$ & $\$ 6,290$ & 555 & 213 & $N / A$ & $\$ 923.1$ \\
\hline LBL & $\$ 2.30$ & $\$ 0.68$ & $\$ 1,617$ & 37 & 14 & $\$ 521.7$ & $\$ 803.0$ \\
\hline LLNL & $\$ 10.23$ & $\$ 2.87$ & $\$ 7,361$ & 63 & 28 & $\$ 1,269.0$ & $\$ 1,734.0$ \\
\hline Mound & $\$ 2.85$ & $\$ 0.16$ & $\$ 2,695$ & 103 & 4 & N/A & N/A \\
\hline ORNL & $\$ 4.49$ & $\$ 0.39$ & $\$ 4,105$ & 139 & 29 & $\$ 214.6$ & $\$ 344.3$ \\
\hline Pantex & $\$ 1.72$ & $\$ 0.84$ & $\$ 883$ & 109 & 24 & N/A & $\$ 532.6$ \\
\hline Pinellas & $\$ 0.38$ & $\$ 0.15$ & $\$ 232$ & 6 & 2 & N/A & $\$ 153.2$ \\
\hline Sandia & $\$ 3.22$ & $\$ 1.10$ & $\$ 2,122$ & 72 & 33 & N/A & $\$ 408.9$ \\
\hline$Y-12$ & $\$ 4.38$ & $\$ 0.42$ & $\$ 3,965$ & 77 & 31 & N/A & $\$ 1,717.9$ \\
\hline Average & $\$ 3.15$ & $\$ 0.85$ & $\$ 2,132$ & 120.73 & 43.69 & & \\
\hline
\end{tabular}


Table B1. (Cont.)

Contractor

Argonne Brookhaven

FermiLab

Kansas City

LANL

LBL

$\underset{\infty}{\infty}$

ORNI

Pantex

Pinellas

Sandia

Y-12

Average

Total Losses

$K \$ \quad \%$ of Oper. Budget $1990 \quad 1980-89 \quad 1990$

$\begin{array}{ccc}\$ 1,942.0 & \text { N/A } & 0.54 \\ \$ 2,079.0 & 1.11 & 0.77 \\ \$ 1,744.0^{\star} & 1.12 & 0.66\end{array}$

$\begin{array}{lll}\$ 1,032.0 & 0.11 & 0.19\end{array}$

$\$ 4,198.1 \quad$ N/A $\quad 0.44$

$\begin{array}{lll}\$ 1,900.3 & 0.77 & 0.97\end{array}$

$\begin{array}{lll}\$ 4,224.0 & 0.54 & 0.39\end{array}$

N/A N/A N/A

$\begin{array}{lll}\$ 2,200.3 & 0.16 & 0.43\end{array}$

$\$ 2,886.6 \quad$ N/A $\quad 1.77$

$\$ 803.2 \quad N / A \quad 0.65$

$\$ 3,323.9 \quad N / A \quad 0.31$

$\$ 8,349.9 \quad \mathrm{~N} / \mathrm{A} \quad 1.52$

* Average worker's compensation costs used 

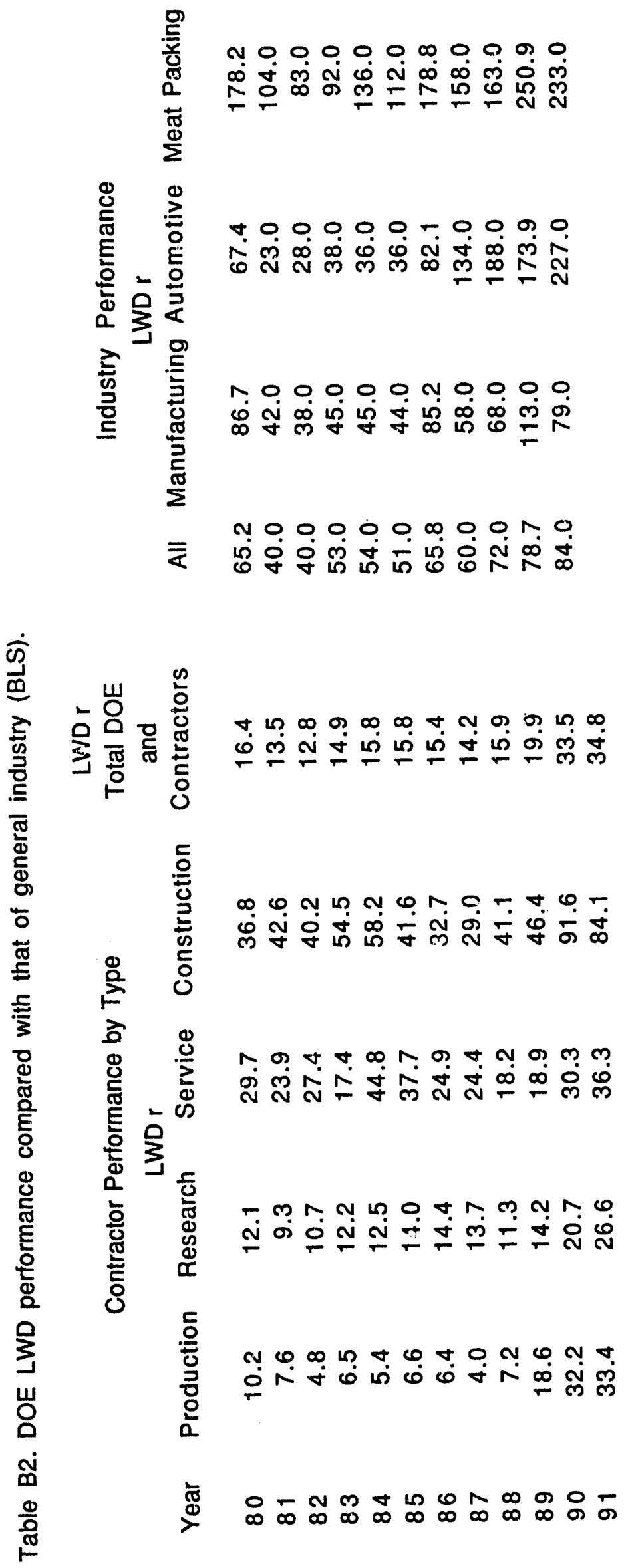
Table B3. Regression analysis output for various comparisons.

Fig. 10. LWD Rate 1980-1989

Constant

4.482

Std Err of Y Est

8.461

R Squared

0.257

No. of Observations 13

Degrees of Freedom 11

$X$ Coefficient(s) $\quad 6.105$

Std Err of Coef.

3.132

Fig. 16. Percent of Budget

Constant

1.024

Std Err of Y Est $\quad 0.704$

R Squared $\quad 0.254$

No. of Observations 13

Degrees of Freedom 11

$X$ Coefficient(s) $\quad 1.372$

Std Err of Coef. $\quad 0.709$

Fig. 18. LWD Rate 1990

Constant

7.460

Std Err of Y Est $\quad 23.86$

R Squared $\quad 0.442$

No. of Observations 13

Degrees of Freedom 11

$X$ Coefficient(s) $\quad 10.32$

Std Err of Coef. $\quad 3.496$

Fig. 25. LWD Rate 1980-1984

Constant $\quad 4.471$

Std Err of Y Est $\quad \mathbf{6 . 0 8 0}$

R Squared $\quad 0.235$

No. of Observations 3

Degrees of Freedom 11

$X$ Coefficient(s) $\quad 4.194$

Std Err of Coef. $\quad 2.283$

Fig. 27. Worker's Comp

Constant

0.0762

Std Err of Y Est $\quad 0.1142$

R Squared $\quad 0.2837$

No. of Observations 11

Degrees of Freedom 9

$X$ Coefficient(s) $\quad 0.0331$

Std Err of Coef. $\quad 0.0175$
Fig. 12. Percent of Contractor

Constant $\quad 0.0319$

Std Err of Y Est $\quad \mathbf{0 . 0 3 7 6}$

R Squared $\quad 0.0862$

No. of Observations 13

Degrees of Freedom 11

X Coefficient(s) $\quad 0.0120$

Std Err of Coef. $\quad 0.0118$

Fig. 17. Avg. Safety Invest

Constant

1494180

Std Err of X Est $\quad 2297602$

R Squared $\quad 0.5578$

No. of Observations 13

Degrees of Freedom 11

$X$ Coefficient(s) $\quad 3184$

Std Err of Coef. 855

Fig. 23. Percent of Budget

Constant $\quad 0.9585$

Std Err of Y Est $\quad 1.5428$

R Squared $\quad 0.4381$

No. of Observations 13

Degrees of Freedom 11

X Coefficient(s) $\quad 3.298$

Std Err of Coef. $\quad \mathbf{1 . 1 2 6}$

Fig. 26. LWD Rate 1985-1989

Constant $\quad 2.692$

Std Err of Y Est $\quad 12.33$

R Squared $\quad 0.283$

No. of Observations 13

Degrees of Freedom 11

$X$ Coefficient(s) $\quad 8.906$

Std Err of Coef. $\quad \mathbf{4 . 2 7 8}$

Fig. 28. Total Loss

Constant $\quad \mathbf{0 . 2 3 2 2}$

Std Err of Y Est $\quad 0.3286$

R Squared $\quad 0.6164$

No. of Observations 11

Degrees of Freedom 9

$X$ Coefficient(s) $\quad 0.1916$

Std Err of Coef. $\quad 0.0504$ 


\section{Appendix C Individual Site Data}

\section{List of Tables}
Table C1. Argonne site data
Table C2. Brookhaven site data
Table C3. Fermilab site data
Table C4. Kansas City Plant site data
Table C5. LANL site data
Table C6. LBL site data
Table C7. LLNL site data
Table C8. Mound site data
Table C9. ORNL site data
Table C10. Pantex site data
Table C11. Pinellas site data
Table C12. Sandia site data
Table C13. Y-12 site data

\section{List of Figures}

Figure C1.1 Argonne LWD rate and safety budget by year Figure C1.2 Argonne LWD rate and safety staff by year

Figure C1.3 Argonne TRC rate and safety budget by year

Figure C1.4 Argonne accident loss and safety budget by year

Figure C2.1 Brookhaven LWD rate and safety budget by year

Figure C2.2 Brookhaven LWD rate and safety staff by year

Figure C2.3 Brookhaven TRC rate and safety budget by year

Figure C2.4 Brookhaven accident loss and safety budget by year

Figure C2.5 Percent of operating budget lost by year, including actual accident losses, estimated radiological consequences, and reported worker's compensation expenditures

Figure C3.1 Fermilab LWD rate and safety budget by year

Figure C3.2 Fermilab LWD rate and safety staff by year

Figure C3.3 Fermilab TRC rate and safety budget by year

Figure C3.4 Fermilab accident loss and safety budget by year

Figure C3.5 Percent of operating budget lost by year, including actual accident losses, estimated radiological consequences, and reported worker's compensation expenditures

Figure C4.1 Kansas City Plant LWD rate and safety budget by year

Figure C4.2 Kansas City Plant LWD rate and safety staff by year

Figure C4.3 Kansas City Plant TRC rate and safety budget by year

Figure C4.4 Kansas City Plant accident loss and safety budget by year

Figure C4.5 Percent of operating budget lost by year, including actual accident losses, estimated radiological consequences, and reported worker's compensation expenditures

Figure C5.1 LANL LWD rate and safety budget by year

Figure C5.2 LANL LWD rate and safety staff by year

Figure C5.3 LANL TRC rate and safety budget by year

Figure C5.4 LANL accident loss and safety budget by year 
Figure C6.1

Figure C6.2

Figure C6.3

Figure C6. 4

Figure C6.5

Figure C7.1

Figure C7.2

Figure C7.3

Figure C7.4

Figure C7.5

Figure C8.1

Figure C8.2

Figure C8.3

Figure C8.4

Figure C9.1

Figure $\mathrm{C} 9.2$

Figure C9.3

Figure C9.4

Figure C9.5

Figure C10.1 Pantex LWD rate and safety budget by year

Figure C10.2 Pantex LWD rate and safety staff by year

Figure C10.3 Pantex TRC rate and safety budget by year

Figure C10.4 Pantex accident loss and safety budget by year

Figure $\mathrm{C} 11.1$ Pinellas LWD rate and safety budget by year

Figure C11.2 Pinellas LWD rate and safety staff by year

Figure C11.3 Pinellas TRC rate and safety budget by year

Figure C11.4 Pinellas accident loss and safety budget by year

Figure C12.1 Sandia LWD rate and safety budget by year

Figure C12.2 Sandia LWD rate and safety staff by year

Figure C12.3 Sandia TRC rate and safety budget by year

Figure C12.4 Sandia accident loss and safety budget by year

Figure C13.1 Y-12 LWD rate and safety budget by year

Figure C13.2 Y-12 LWD rate and safety staff by year

Figure C13.3 Y-12 TRC rate and safety budget by year

Figure C13.4 Y-12 accident loss and safety budget by year 


\section{C1. Argonne}

Argonne is a multiprogram national R\&D laboratory. Security injury statistics were separated from other site data in 1987. A Tiger Team appraisal was conducted in October 1990. No worker's compensation data is available prior to 1985 . 
ㄱำ $\infty \leftarrow \infty$

$\infty$ 乐 $N \infty \infty$

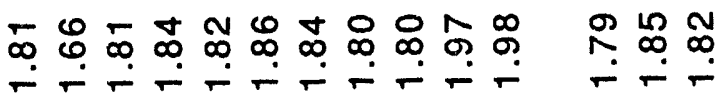

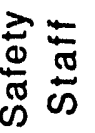

४

ตั่

क व 6 -

ㄴ $00 \forall \infty=0 \infty 0 \%$

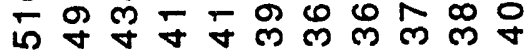

ㄴํํㅇำ

i $\dot{+} \dot{\dagger} \dot{0} \infty \dot{0} \dot{0} \dot{0} \dot{0}$

ำ 운

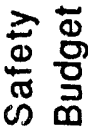

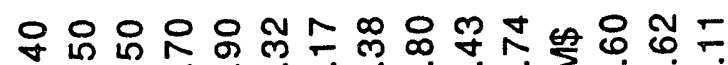

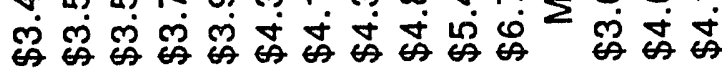

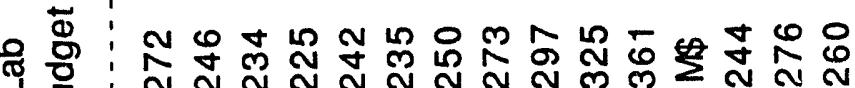

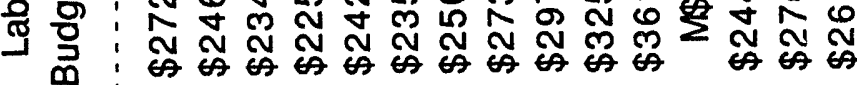

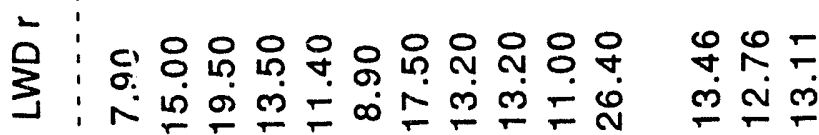

¿্র

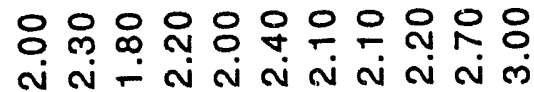

융 i N N

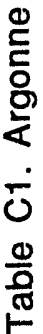

$\forall \stackrel{+}{\dot{N}} \dot{0}$ 施

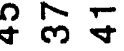

$\stackrel{\infty}{\infty} \stackrel{\infty}{1}$ $\forall \dot{\square}$
雨

O-NM

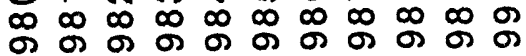

官

荈是是 
Table C1. (Cont.)

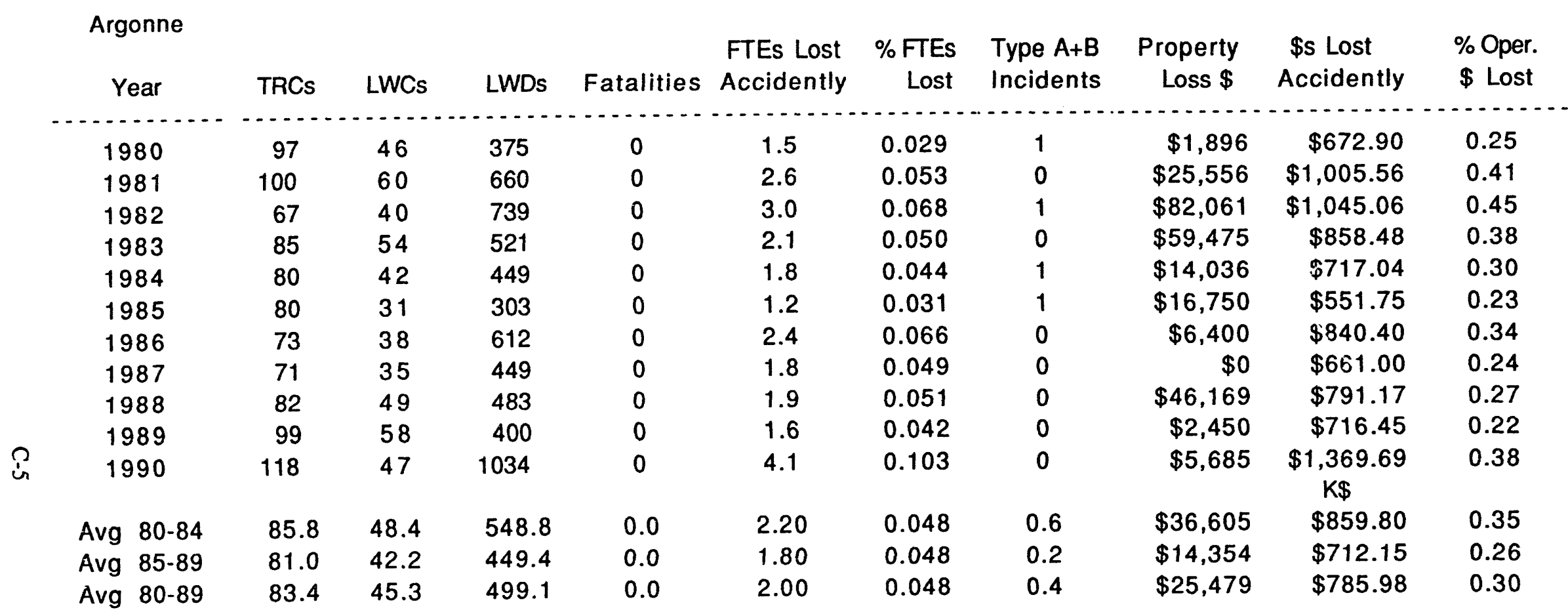


Table C1. (Cont.)

\begin{tabular}{|c|c|c|c|c|c|c|c|}
\hline $\begin{array}{c}\text { Argonne } \\
\text { Year }\end{array}$ & $\begin{array}{l}\text { Person } \\
\text { Rem }\end{array}$ & $\begin{array}{c}\$ 1,000 \\
\text { per ManRem }\end{array}$ & $\begin{array}{c}\text { Acc. + Rad. } \\
\text { \$ Lost }\end{array}$ & $\begin{array}{c}\text { Acc. + Rad. } \\
\% \text { Lost }\end{array}$ & $\begin{array}{l}\text { Worker's } \\
\text { Comp Costs }\end{array}$ & $\begin{array}{l}\text { Total } \\
\% \text { Lost }\end{array}$ & $\begin{array}{l}\text { Worker's Comp } \\
\% \text { of Oper. } \$\end{array}$ \\
\hline 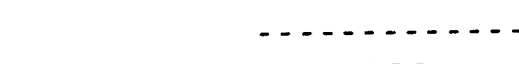 & & $\ldots \ldots$ & - & $\ldots$ & $\ldots$ & & \\
\hline 1980 & 201 & $\$ 201$ & $\$ 874$ & 0.32 & $n / a$ & & \\
\hline 1981 & 196 & $\$ 196$ & $\$ 1,202$ & 0.49 & $\mathrm{n} / \mathrm{a}$ & & \\
\hline 1982 & 151 & $\$ 151$ & $\$ 1,196$ & 0.51 & $\mathrm{n} / \mathrm{a}$ & & \\
\hline 1983 & 114 & $\$ 114$ & $\$ 972$ & 0.43 & $\mathrm{n} / \mathrm{a}$ & & \\
\hline 1984 & 115 & $\$ 115$ & $\$ 832$ & 0.34 & $\mathrm{n} / \mathrm{a}$ & & \\
\hline 1985 & 87 & $\$ 87$ & $\$ 639$ & 0.27 & $\$ 157$ & 0.34 & 0.067 \\
\hline 1986 & 76 & $\$ 76$ & $\$ 916$ & 0.37 & $\$ 443$ & 0.54 & 0.177 \\
\hline 1987 & 84 & $\$ 84$ & $\$ 745$ & 0.27 & $\$ 249$ & 0.36 & 0.091 \\
\hline 1988 & 91 & $\$ 91$ & $\$ 882$ & 0.30 & $\$ 387$ & 0.43 & 0.130 \\
\hline 1989 & 61 & $\$ 61$ & $\$ 777$ & 0.24 & $\$ 292$ & 0.33 & 0.090 \\
\hline 1990 & 64 & $\$ 64$ & $\$ 1,434$ & 0.40 & $\$ 509$ & 0.54 & 0.141 \\
\hline & & $\mathrm{K} \$$ & $K \$$ & & $K \$$ & & \\
\hline Avg $8 C-84$ & 155 & $\$ 155$ & $\$ 1,015$ & 0.42 & & & \\
\hline Avg $85-89$ & 80 & $\$ 80$ & $\$ 792$ & 0.29 & $\$ 306$ & 0.40 & 0.111 \\
\hline Avg $80-89$ & 118 & $\$ 118$ & $\$ 904$ & 0.35 & & & \\
\hline
\end{tabular}




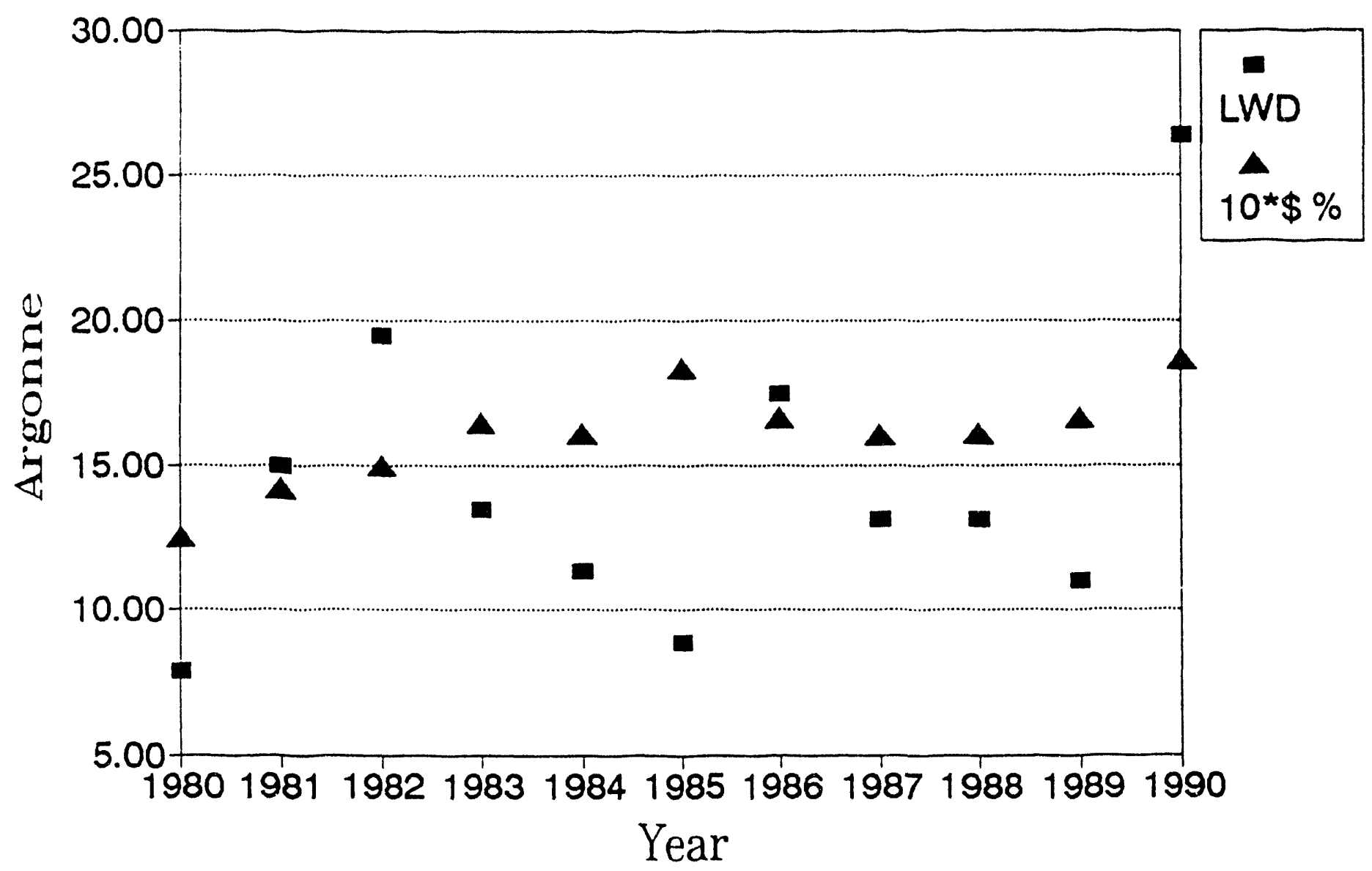

Figure C1.1. Lost workdays per 200k man-hr, 10 times safety budget percentage. 


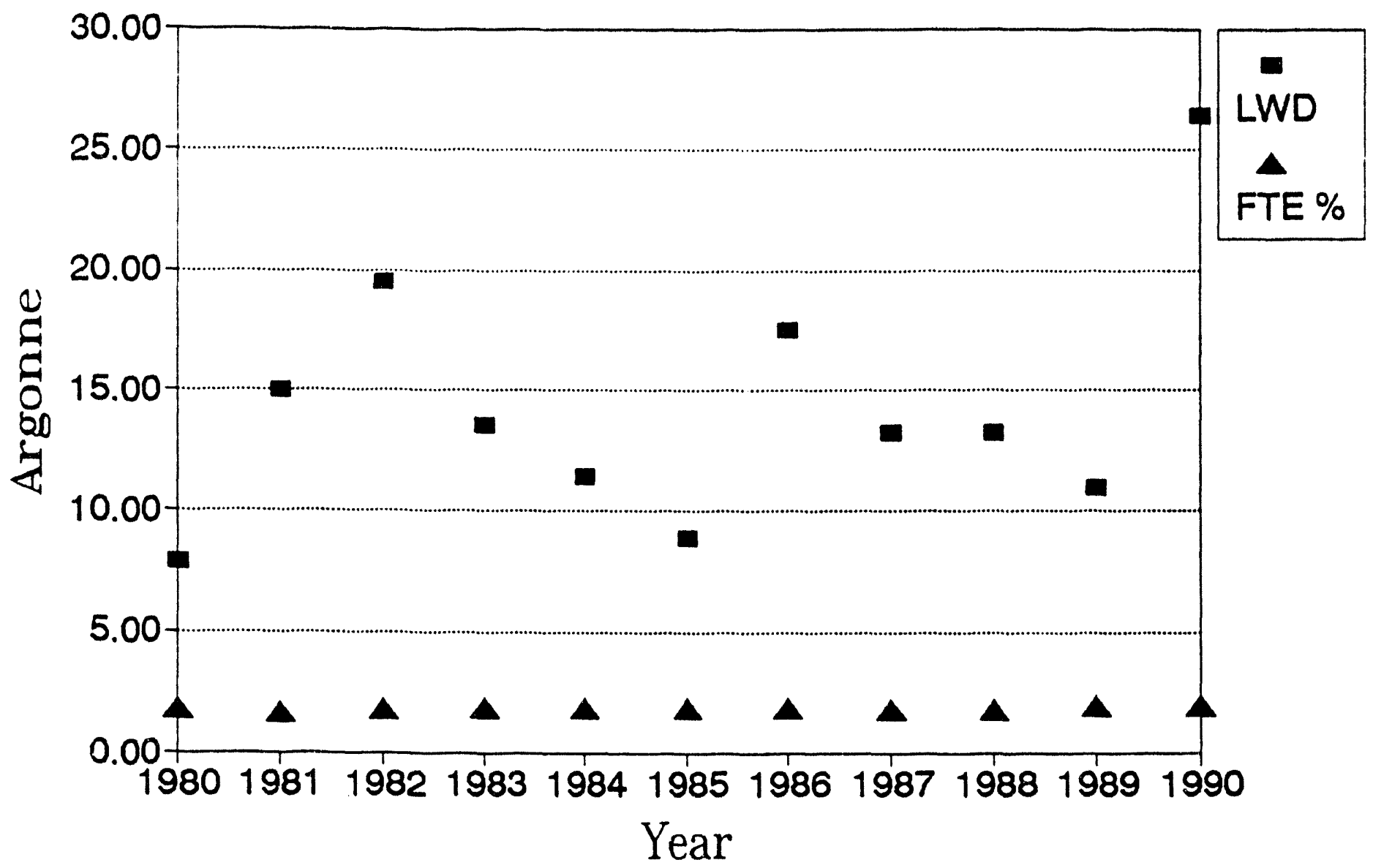

Figure C1.2. Lost workdays per $200 \mathrm{k}$ man-hr, safety staff as percent of Laboratory manpower. 


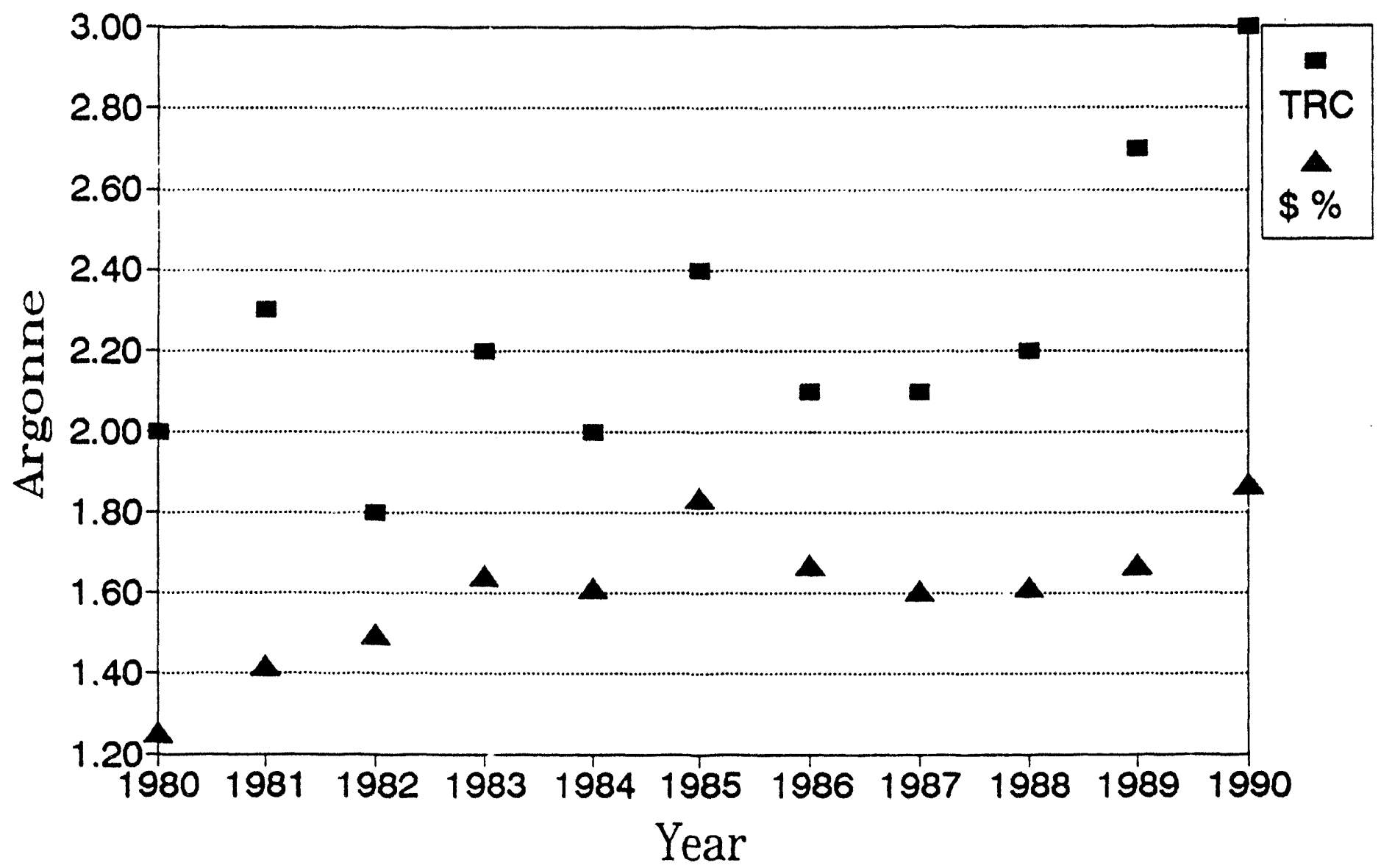

Figure C1.3. Total reportable case rate, percent of Laboratory budget spent on safety. 


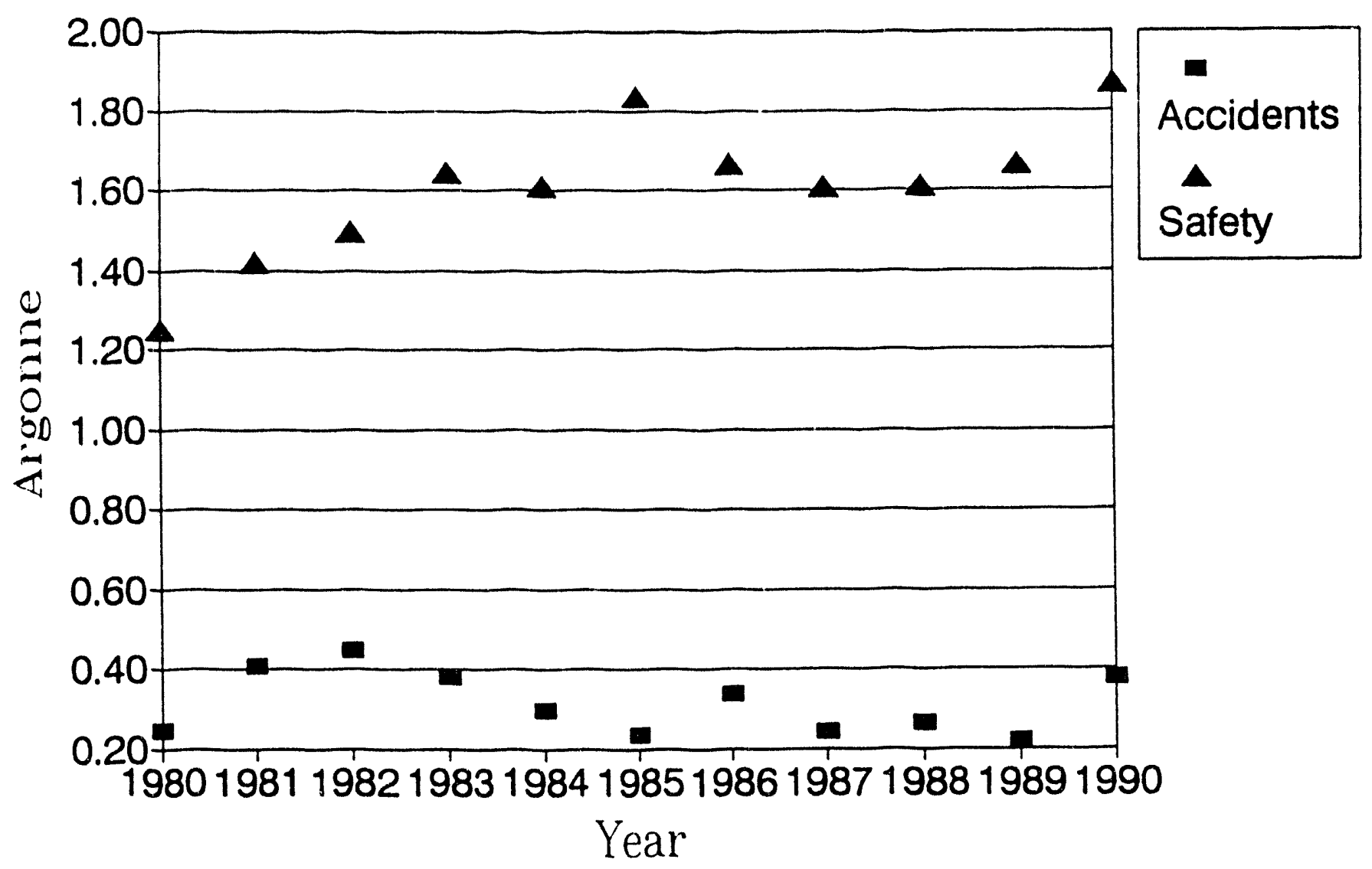

Figure C1.4. Percent of budget lost accidentally, percent of Laboratory budget spent on safety. 


\section{C2. Brookhaven}

Brookhaven is a multiprogram national R\&D laboratory. This Laboratory changed its reporting criteria for injury incidents in 1986, in response to DOE audits of its OSHA-like logs, to a more strict interpretation of requirements. This change resulted in an increase that is obvious in Fig. C2.1. The high dollar loss value observed in 1986 in Fig. C2.4 is due to two fatalities and three serious incidents that year. Security is included in the site statistics until 1989. A Tiger Team appraisal was conducted in March 1990. 
Table C2. Brookhaven site data.

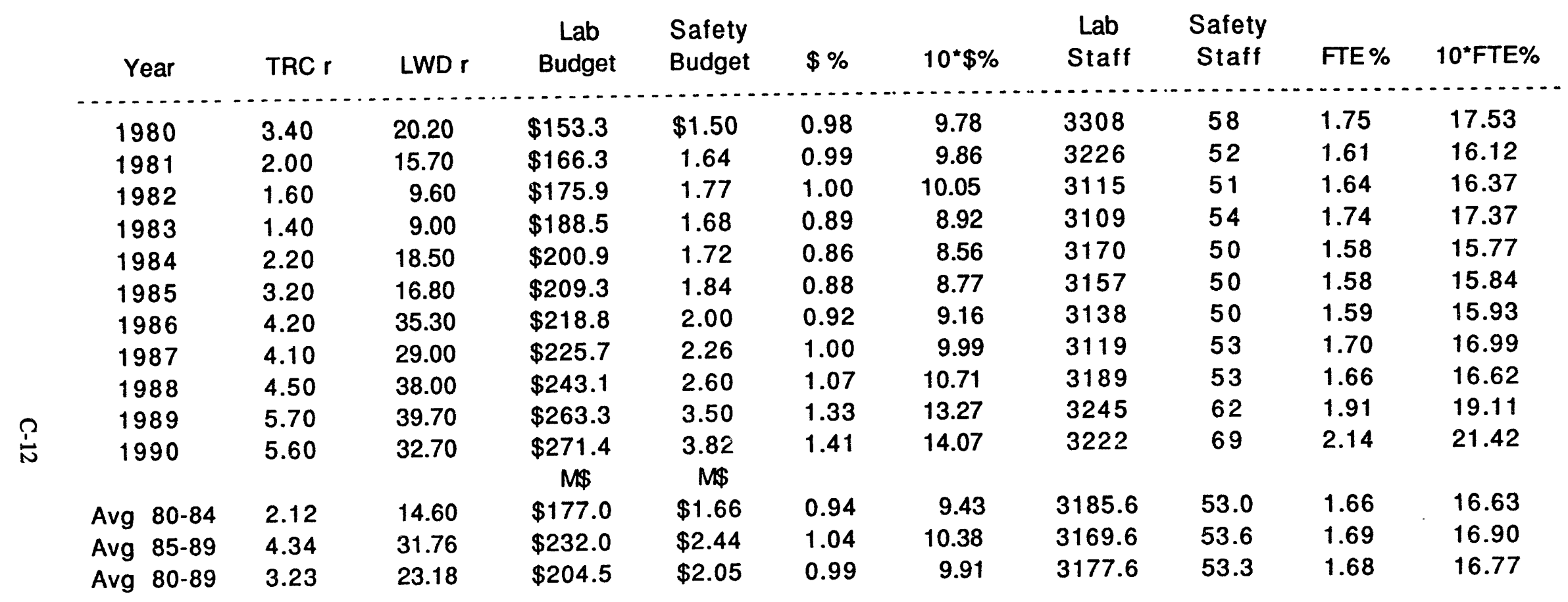


Table C2. (Cont.)

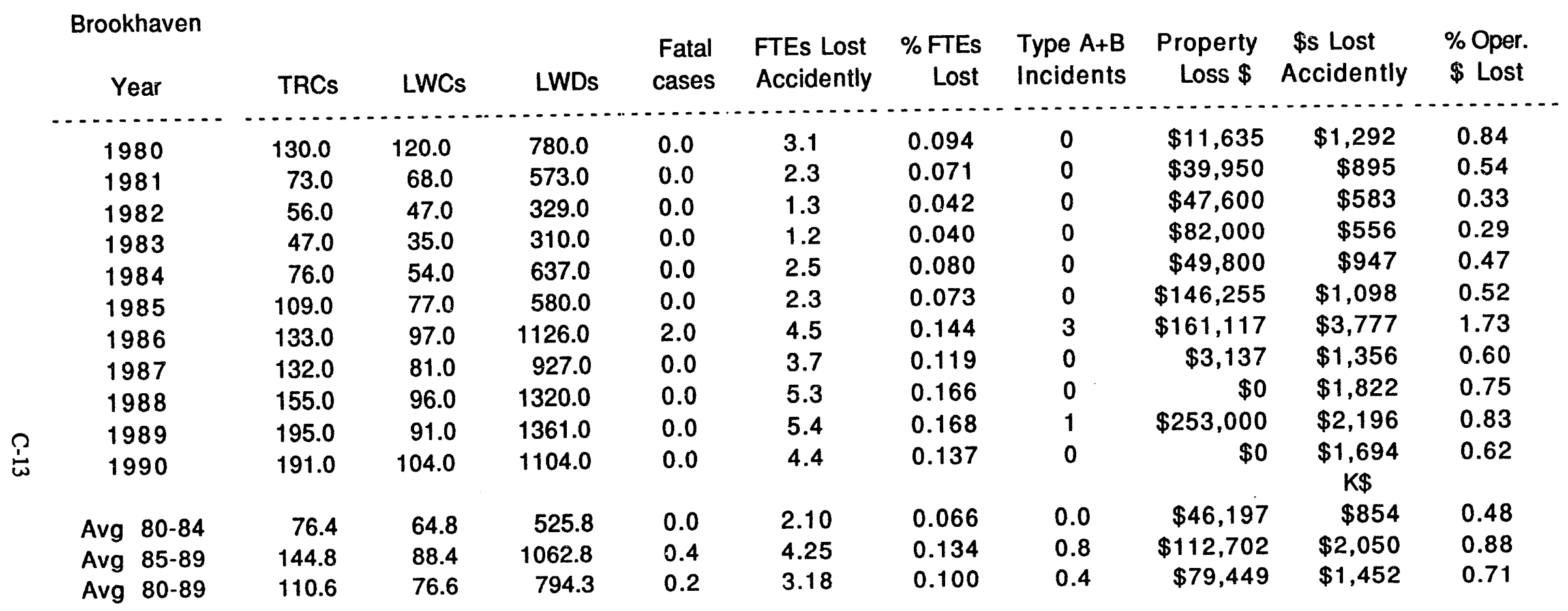


Table C2. (Cont.)

\begin{tabular}{|c|c|c|c|c|c|c|c|c|}
\hline & $\begin{array}{c}\text { Brookhaven } \\
\text { Year }\end{array}$ & $\begin{array}{c}\text { Person } \\
\text { Rem }\end{array}$ & $\begin{array}{c}\$ 1,000 \\
\text { per ManRem }\end{array}$ & $\begin{array}{c}\text { Acc. + Rad. } \\
\$ \text { Lost }\end{array}$ & $\begin{array}{c}\text { Acc. + Rad. } \\
\% \text { Lost }\end{array}$ & $\begin{array}{l}\text { Worker's } \\
\text { Comp Costs }\end{array}$ & $\begin{array}{l}\text { Total } \\
\% \text { Lost }\end{array}$ & $\begin{array}{l}\text { Worker's Comp. } \\
\% \text { of Oper. \$ }\end{array}$ \\
\hline & - & . & $\ldots$. & & & $\ldots$ & & \\
\hline & 1980 & 347 & $\$ 347$ & $\$ 1,639$ & 1.07 & $\$ 346$ & 1.29 & 0.226 \\
\hline & 1981 & 300 & $\$ 300$ & $\$ 1,195$ & 0.72 & $\$ 374$ & 0.94 & 0.225 \\
\hline & 1982 & 202 & $\$ 202$ & $\$ 785$ & 0.45 & $\$ 365$ & 0.65 & 0.208 \\
\hline & 1983 & 269 & $\$ 269$ & $\$ 825$ & 0.44 & $\$ 402$ & 0.65 & 0.213 \\
\hline & 1984 & 289 & $\$ 289$ & $\$ 1,236$ & 0.62 & $\$ 449$ & 0.84 & 0.223 \\
\hline & 1985 & 264 & $\$ 264$ & $\$ 1,362$ & 0.65 & $\$ 757$ & 1.01 & 0.361 \\
\hline & 1986 & 211 & $\$ 211$ & $\$ 3,988$ & 1.82 & $\$ 408$ & 2.01 & 0.186 \\
\hline & 1987 & 170 & $\$ 170$ & $\$ 1,526$ & 0.68 & $\$ 521$ & 0.91 & 0.231 \\
\hline & 1988 & 149 & $\$ 149$ & $\$ 1,971$ & 0.81 & $\$ 254$ & 0.92 & 0.104 \\
\hline$?$ & 1989 & 136 & $\$ 136$ & $\$ 2,332$ & 0.89 & $\$ 215$ & 0.97 & 0.082 \\
\hline 客 & 1990 & 91 & $\$ 91$ & $\$ 1,785$ & 0.66 & $\$ 294$ & 0.77 & 0.108 \\
\hline & & & $\$ K$ & $\$ K$ & & $\$ K$ & & \\
\hline & Avg $80-84$ & 281 & $\$ 281$ & $\$ 1,136$ & 0.64 & $\$ 387$ & 0.86 & 0.219 \\
\hline & Avg $85-89$ & 186 & $\$ 186$ & $\$ 2,236$ & 0.96 & $\$ 431$ & 1.15 & 0.186 \\
\hline & Avg $80-89$ & 234 & $\$ 234$ & $\$ 1,686$ & 0.82 & $\$ 409$ & 1.02 & 0.200 \\
\hline
\end{tabular}




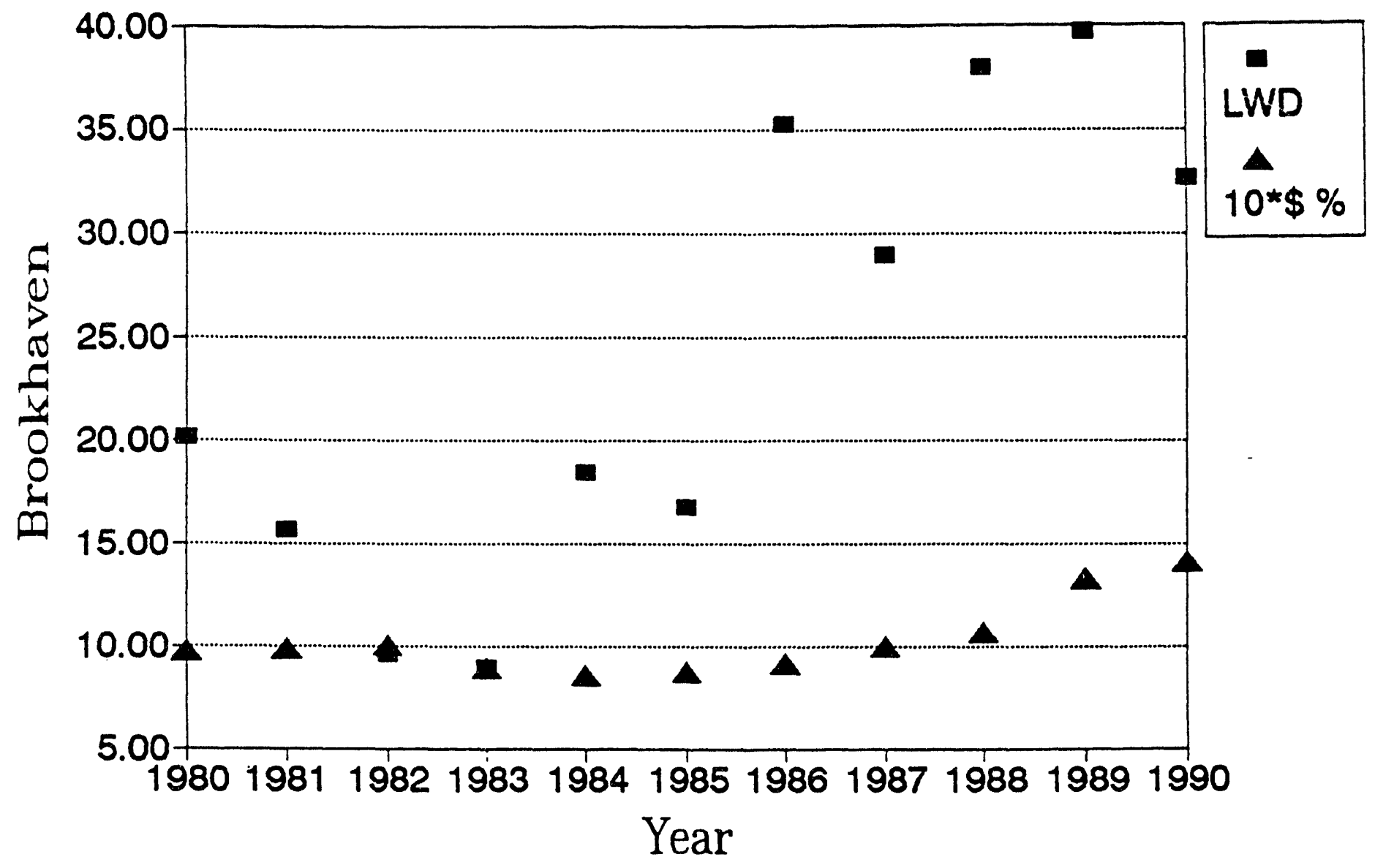

Figure C2.1. Lost workdays per 200k man-hr, 10 times safety budget percentage. 


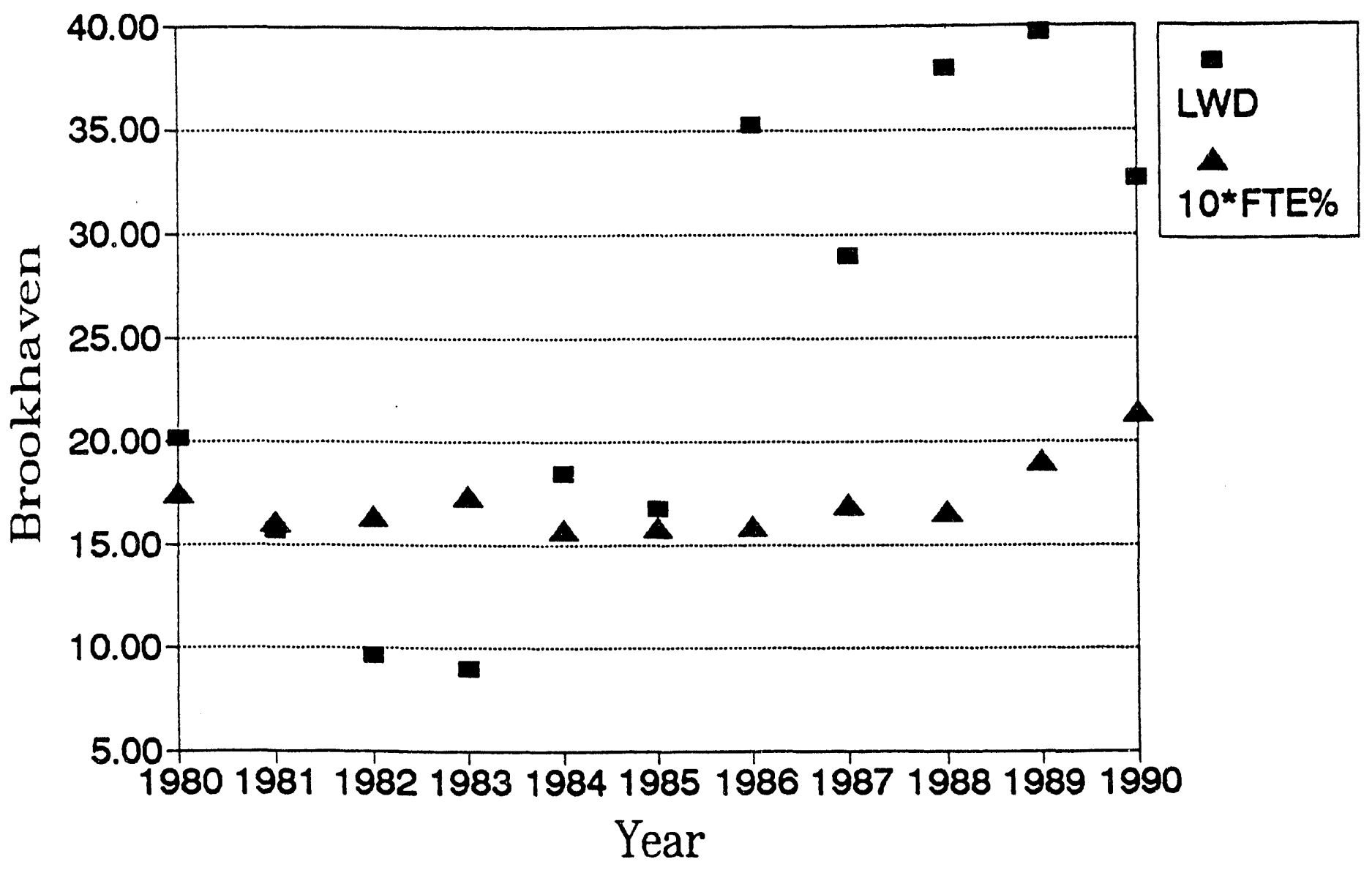

Figure C2.2. Lost workdays per 200k man-hr, 10 times safety manpower percentage. 


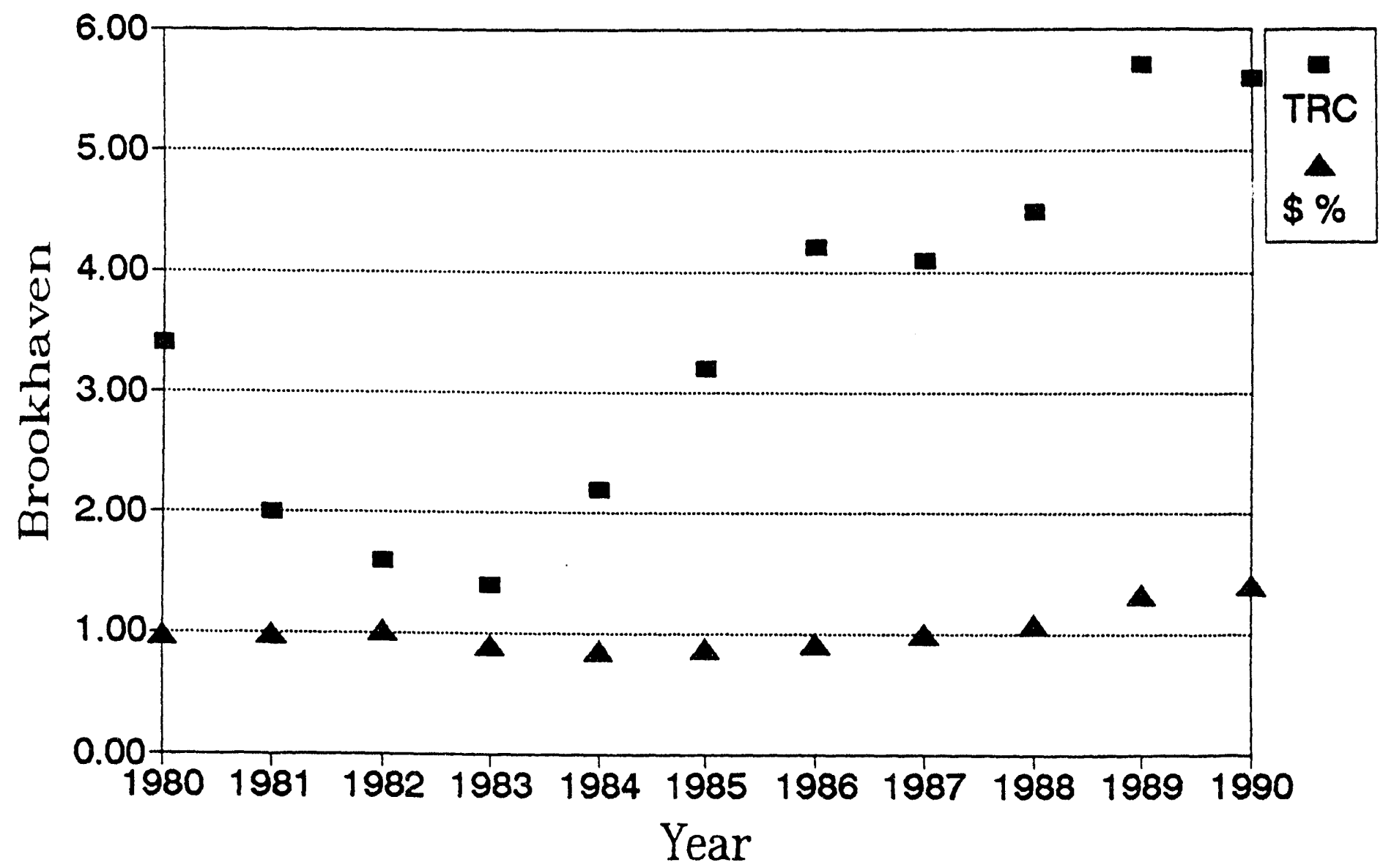

Figure C2.3. Total reportable case rate, percent of Laboratory budget spent on safety. 


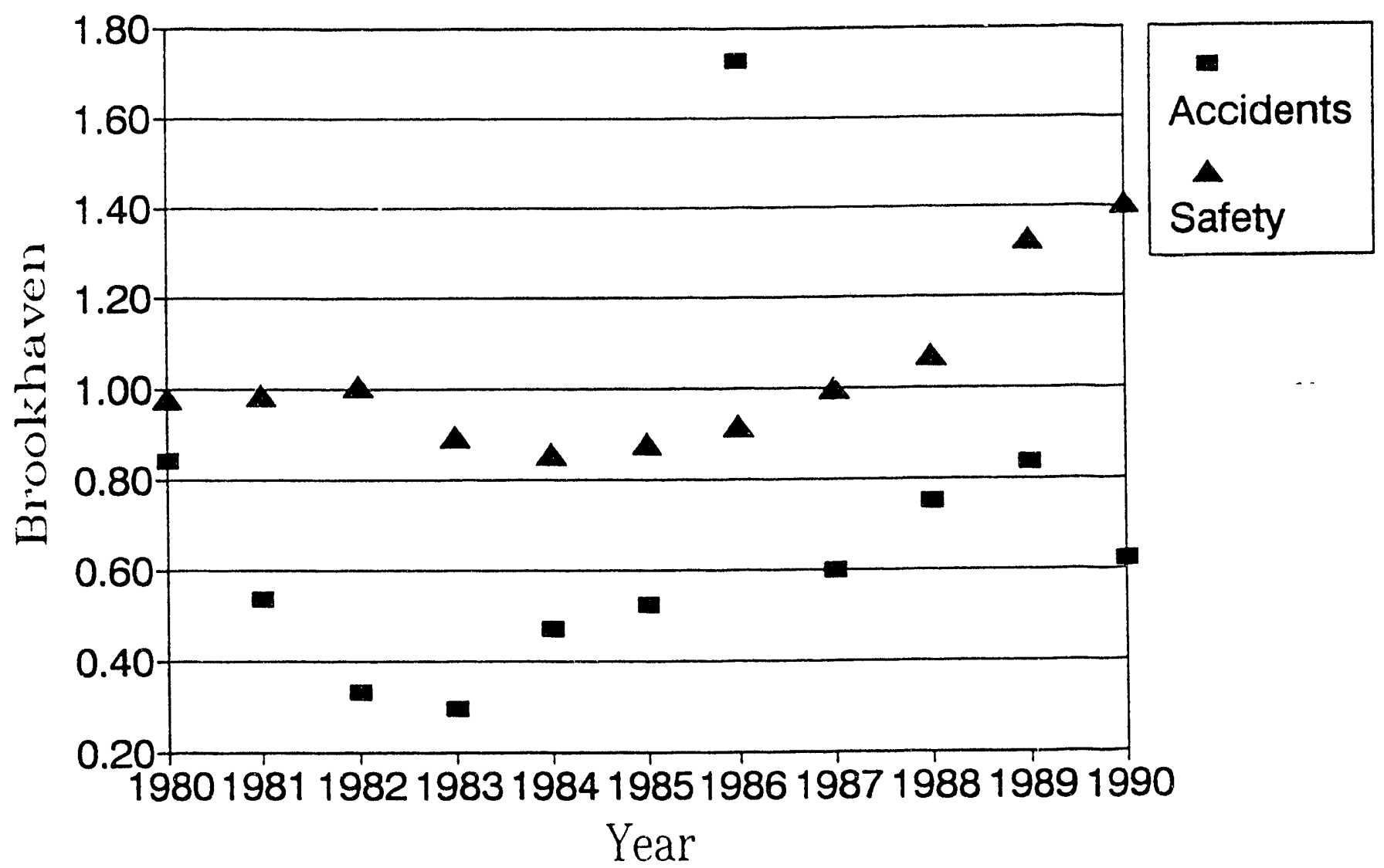

Figure C2.4. Percent of budget lost accidentally, percent of Laboratory budget spent on safety. 


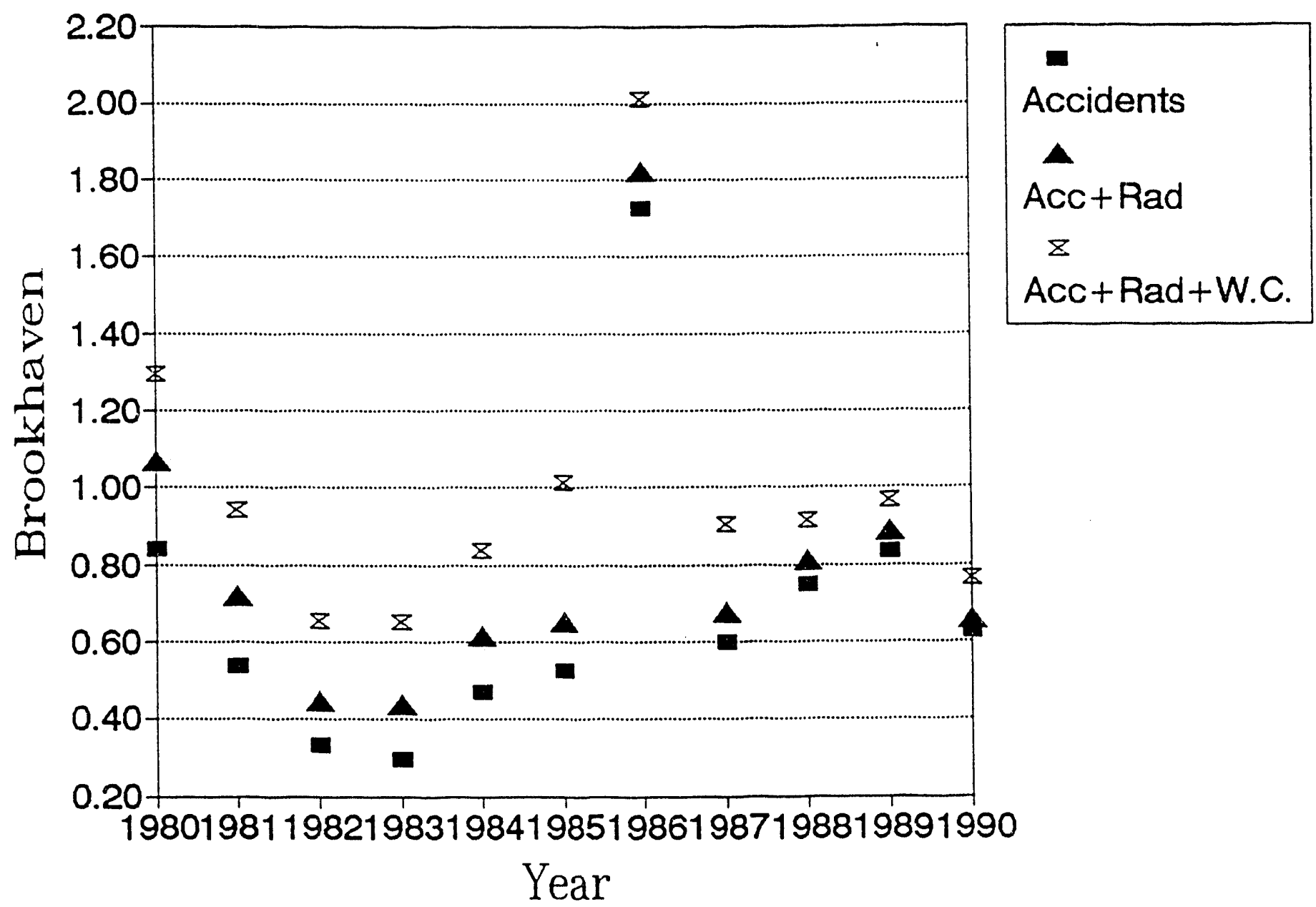

Figure C2.5. Percent of operating budget lost by year, including actual accident losses, estimated radiological consequences, and reported worker's compensation expenditures. 


\section{C3. Fermilab}

Fermilab is the national accelerator laboratory, conducting focused R\&D. Individual programs and departments hire their own safety staff/professionals for mini safety departments. The central safety department provides oversight and additional expertise as needed. FTEs and costs were combined for comparison with the other sites. OSHA reporting was improved in 1985, with some observed effect on TRC. A Tiger Team appraisal was conducted in May 1992. 
Table C3. Fermilab site data.

\begin{tabular}{|c|c|c|c|c|c|c|c|c|c|c|}
\hline Year & TRC r & LWD r & $\begin{array}{l}\text { Lab } \\
\text { Budget }\end{array}$ & $\begin{array}{l}\text { Safety } \\
\text { Budget }\end{array}$ & $\$ \%$ & $10 * \$ \%$ & $\begin{array}{l}\text { Lab } \\
\text { Staff }\end{array}$ & $\begin{array}{l}\text { Safety } \\
\text { Staff }\end{array}$ & FTE \% & 10*FTE\% \\
\hline & & & & $\$ 2.09$ & & 24.72 & $18 ?$ & 44 & 2.41 & 24.14 \\
\hline & $\begin{array}{l}4.6 \\
2.9\end{array}$ & 74.4 & $\begin{array}{l}\$ 84.6 \\
\$ 96.2\end{array}$ & $\begin{array}{l}\$ 2.09 \\
\$ 2.64\end{array}$ & 2.74 & $\begin{array}{l}24.6 \\
27.45\end{array}$ & 1947 & $\begin{array}{l}44 \\
46\end{array}$ & 2.36 & $\begin{array}{l}24.14 \\
23.63\end{array}$ \\
\hline 1982 & $\begin{array}{l}2.9 \\
2.4\end{array}$ & $\begin{array}{l}14.8 \\
16.6\end{array}$ & $\begin{array}{r}\$ 96.2 \\
\$ 107.1\end{array}$ & $\begin{array}{l}\$ 2.64 \\
\$ 3.95\end{array}$ & 3.69 & 36.90 & 1931 & 52 & 2.69 & 26.93 \\
\hline 1983 & 0.9 & 4.7 & $\$ 132.1$ & $\$ 3.95$ & 2.99 & 29.90 & 2058 & 55 & 2.67 & 26.72 \\
\hline 1984 & 0.9 & 2.1 & $\$ 140.8$ & $\$ 3.91$ & 2.78 & 27.78 & 2188 & 49 & 2.24 & 22.39 \\
\hline 1985 & 2.6 & 19.5 & $\$ 151.0$ & $\$ 4.11$ & 2.72 & 27.22 & 2125 & 51 & 2.40 & 24.00 \\
\hline 1986 & 3.7 & 75.0 & $\$ 152.8$ & $\$ 3.86$ & 2.53 & 25.26 & 2108 & 52 & 2.47 & 24.67 \\
\hline 1987 & 3.6 & 39.6 & $\$ 166.9$ & $\$ 4.47$ & 2.68 & 26.78 & 2000 & 51 & 2.55 & 25.50 \\
\hline $\begin{array}{l}1988 \\
1989\end{array}$ & 3.5 & 26.6 & $\$ 179.1$ & $\$ 4.42$ & 2.47 & 24.67 & 2035 & 60 & 2.95 & 29.48 \\
\hline $\begin{array}{l}1989 \\
1990\end{array}$ & 3.8 & 31.6 & $\$ 195.6$ & $\$ 5.54$ & 2.83 & 28.32 & 2150 & 69.5 & 3.23 & 32.33 \\
\hline 1990 & 3.3 & 44.6 & $\$ 191.4$ & $\$ 5.73$ & 2.99 & 29.93 & 2265 & 75 & 3.31 & 33.11 \\
\hline Avg $80-84$ & 2.34 & 22.52 & $\begin{array}{c}M \$ \\
\$ 112.1\end{array}$ & $\$ 3.31$ & 2.93 & 29.35 & 1989.4 & 49.2 & 2.48 & 24.76 \\
\hline Avg $85-89$ & 3.44 & 38.46 & $\$ 169.1$ & $\$ 4.48$ & 2.65 & 26.45 & 2083.6 & 56.7 & 2.72 & $\begin{array}{l}24.16 \\
27.20\end{array}$ \\
\hline Avg $80-89$ & 2.89 & 30.49 & $\$ 140.6$ & $\$ 3.89$ & 2.79 & 27.90 & 2036.5 & 53.0 & 2.60 & 25.98 \\
\hline
\end{tabular}


Table C3. (Cont.)

\begin{tabular}{|c|c|c|c|c|c|c|c|c|c|c|}
\hline Fermilab & TRCs & LWCs & LWDs & $\begin{array}{l}\text { Fatal } \\
\text { Cases }\end{array}$ & $\begin{array}{l}\text { FTEs Lost } \\
\text { Accidently }\end{array}$ & $\begin{array}{c}\% \text { FTES } \\
\text { Lost }\end{array}$ & $\begin{array}{l}\text { Type A+B } \\
\text { Incidents }\end{array}$ & $\begin{array}{c}\text { Property } \\
\text { Loss \$ }\end{array}$ & $\begin{array}{c}\text { \$s Lost } \\
\text { Accidently }\end{array}$ & $\begin{array}{l}\text { \% Oper. } \\
\text { \$ Lost }\end{array}$ \\
\hline$\ldots$ & & & & & & & & & & \\
\hline 1980 & 88 & 72 & 1419 & 0 & 5.7 & 0.311 & 0 & $\$ 40,197$ & $\$ 1,779$ & 2.10 \\
\hline 1981 & 58 & 28 & 300 & 0 & 1.2 & 0.062 & 0 & $\$ 15,348$ & $\$ 487$ & 0.51 \\
\hline 1982 & 48 & 46 & 326 & 0 & 1.3 & 0.068 & 0 & $\$ 18,900$ & $\$ 533$ & 0.50 \\
\hline 1983 & 24 & 18 & 121 & 0 & 0.5 & 0.024 & 0 & $\$ 4,100$ & $\$ 209$ & 0.16 \\
\hline 1984 & 21 & 17 & 53 & 0 & 0.2 & 0.010 & 1 & $\$ 48,000$ & $\$ 187$ & 0.13 \\
\hline 1985 & 63 & 39 & 480 & 0 & 1.9 & 0.090 & 1 & $\$ 1,204,500$ & $\$ 1,899$ & 1.26 \\
\hline 1986 & 90 & 62 & 1832 & 0 & 7.3 & 0.348 & 0 & $\$ 28,800$ & $\$ 2,165$ & 1.42 \\
\hline 1987 & 80 & 53 & 884 & 0 & 3.5 & 0.177 & 1 & $\$ 1,054,000$ & $\$ 2,214$ & 1.33 \\
\hline 1988 & 83 & 55 & 621 & 0 & 2.5 & 0.122 & 0 & $\$ 48,100$ & $\$ 945$ & 0.53 \\
\hline 1989 & 102 & 74 & 848 & 0 & 3.4 & 0.158 & 0 & $\$ 30,208$ & $\$ 1,230$ & 0.63 \\
\hline 1990 & 86 & 58 & 1162 & 0 & 4.6 & 0.205 & 0 & $\$ 25,441$ & $\begin{array}{r}\$ 1,475 \\
\mathrm{~K} \$\end{array}$ & 0.77 \\
\hline Avg $80-84$ & 47.8 & 36.2 & 443.8 & 0.0 & 1.78 & 0.089 & 0.2 & $\$ 25,309$ & $\$ 639$ & 0.57 \\
\hline Avg $85-89$ & 83.6 & 56.6 & 933.0 & 0.0 & 3.73 & 0.179 & 0.4 & $\$ 473,122$ & $\$ 1,691$ & 1.00 \\
\hline Avg $80-89$ & 65.7 & 46.4 & 688.4 & 0.0 & 2.75 & 0.135 & 0.3 & $\$ 249,215$ & $\$ 1,165$ & 0.83 \\
\hline
\end{tabular}


Table C3. (Cont.)

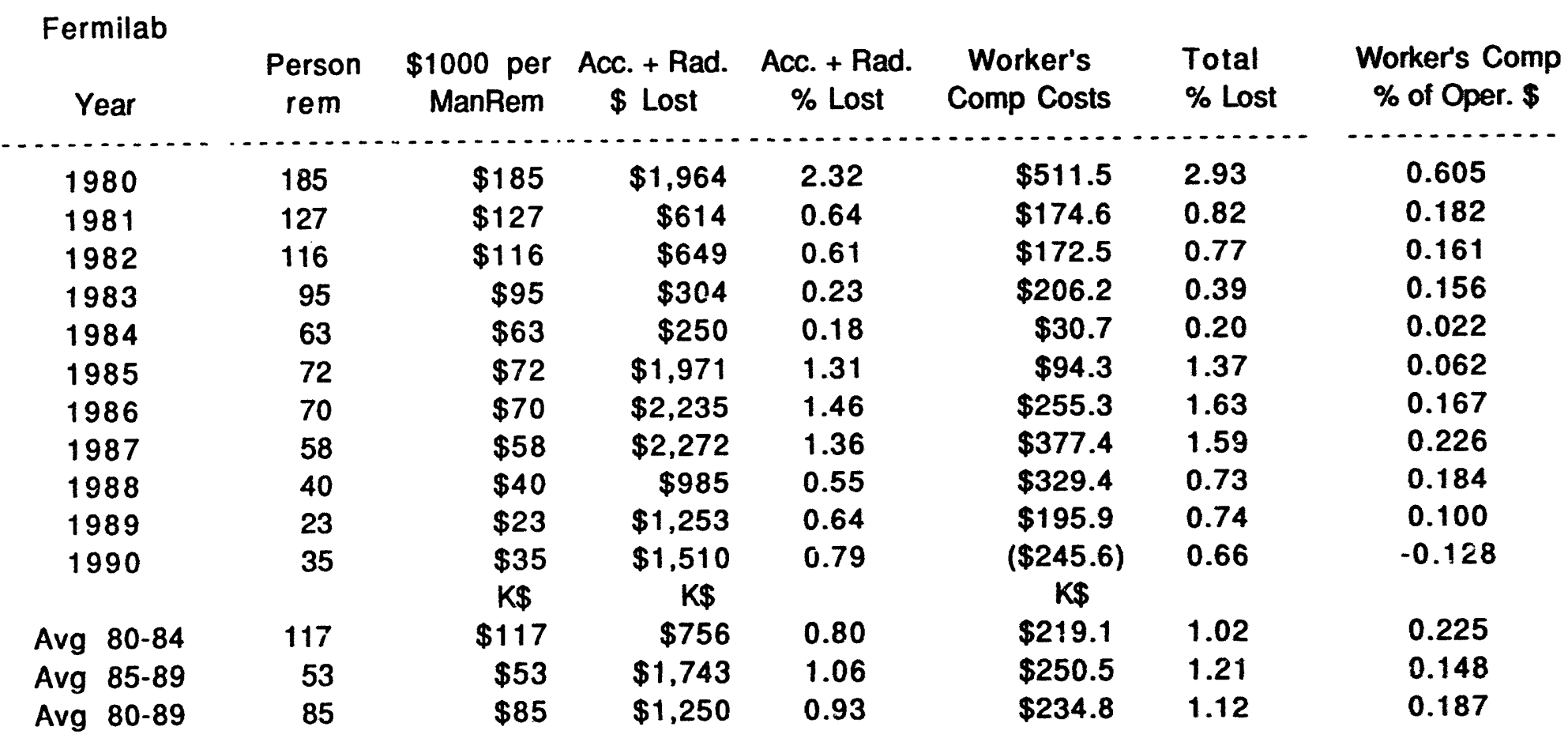




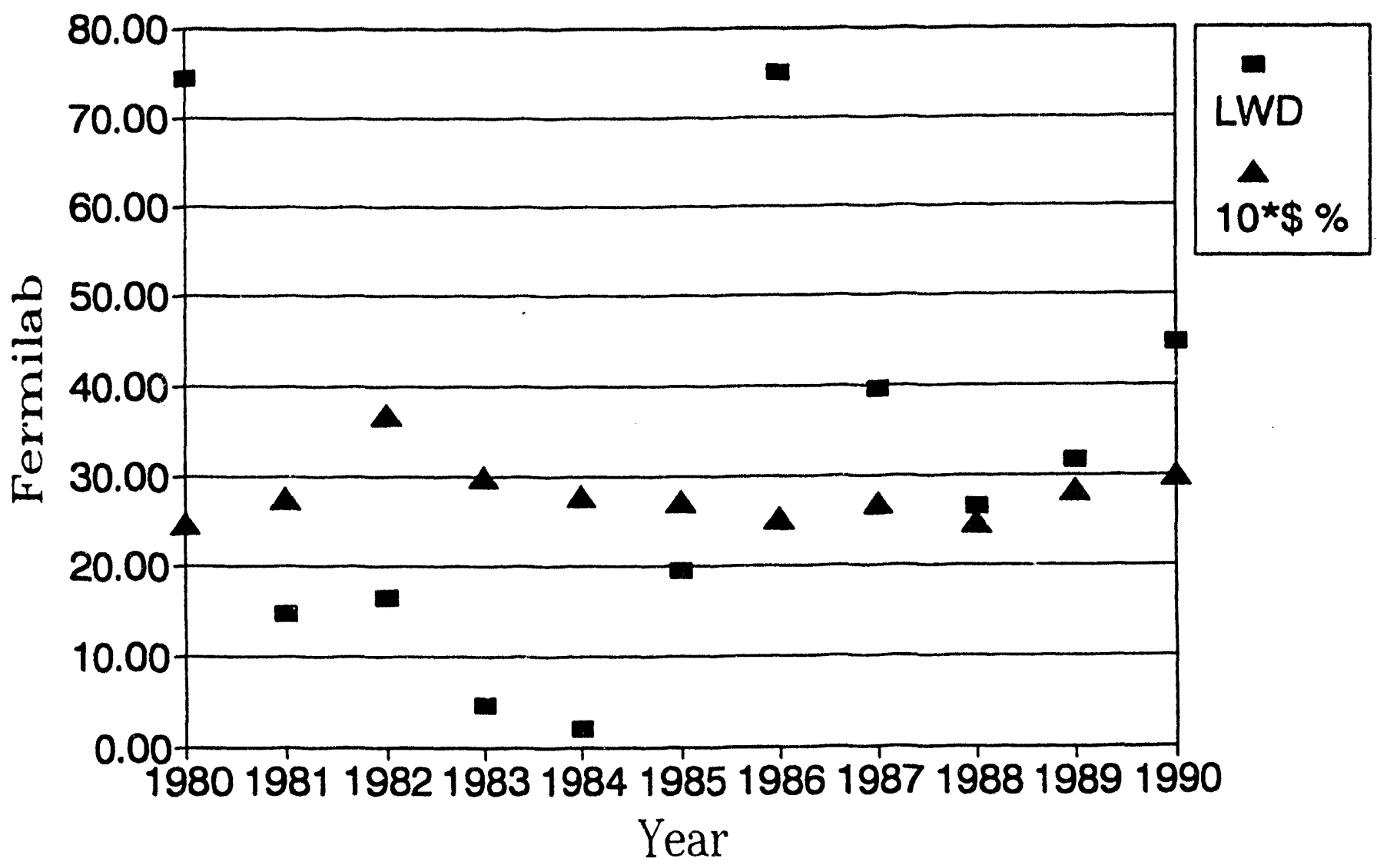

Figure C3.1. Lost workdays per 200k man-hr, 10 times safety budget percentage. 


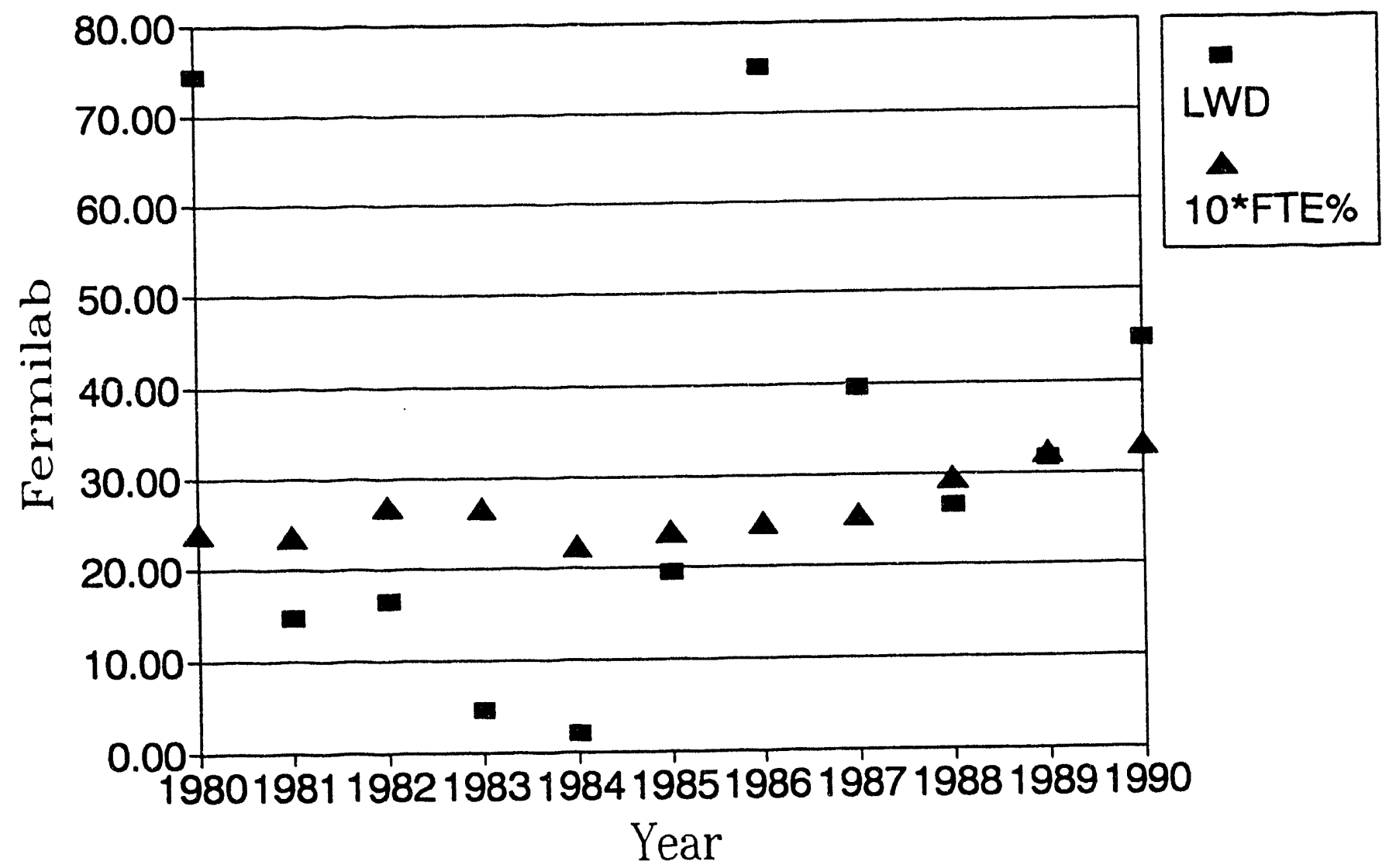

Figure C3.2. Lost workdays per 200k man-hr, 10 times safety manpower percentage. 


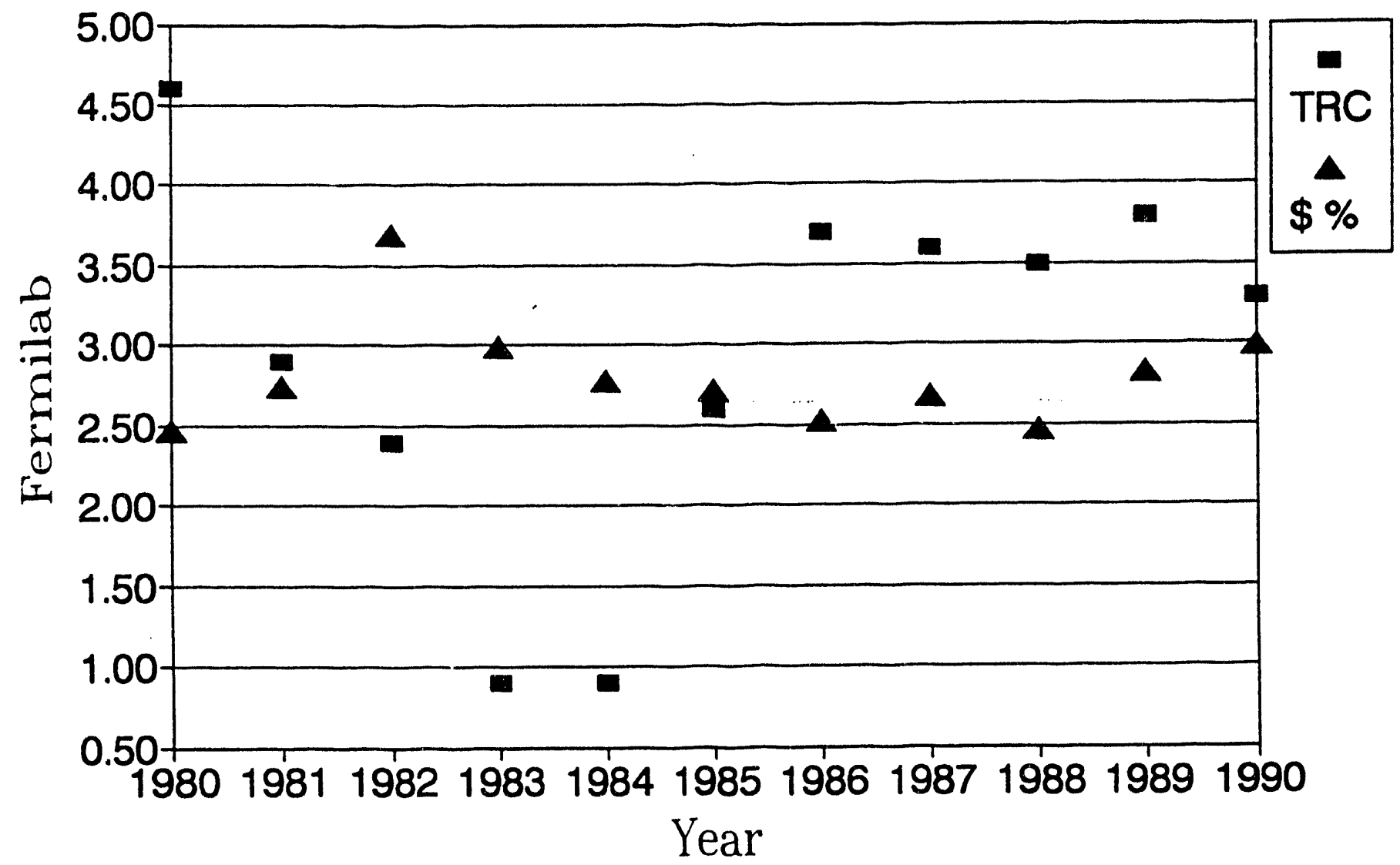

Figure C3.3. Total reportable case rate, percent of Laboratory budget spent on safoty. 


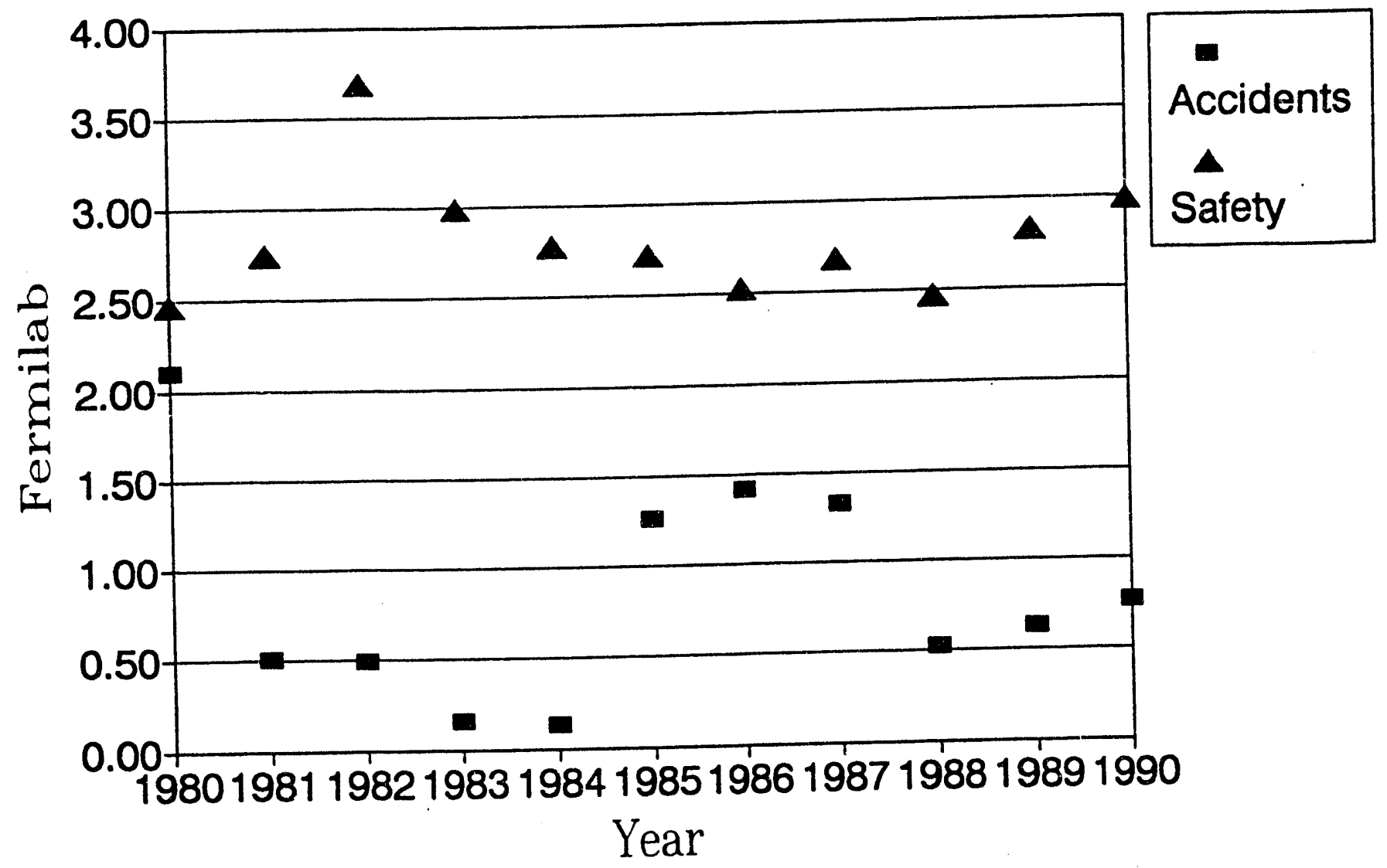

Figure C3.4. Percent of budget lost accidentally, percent of Laboratory budget spent on safety. 


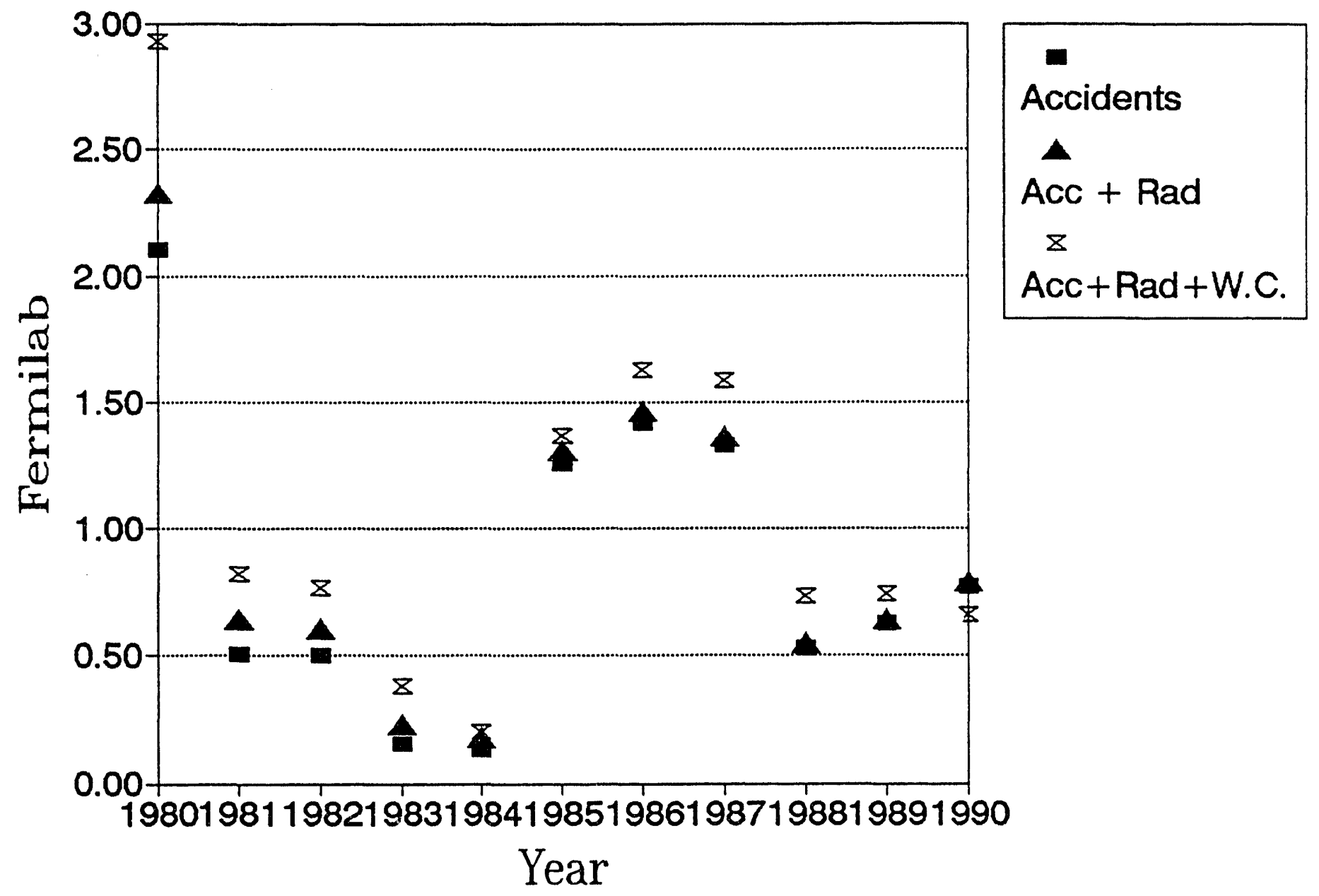

Figure C3.5. Percent of operating budget lost by year, including actual accident losses, estimated radiological consequences, and reported worker's compensation expenditures. 


\section{C4. Kansas City Plant}

The Kansas City Plant is primarily a production facility. It has a very small radiation safety effort. There was a change of contractor, from Bendix to Allied Signal, in 1987; however, it is too early to determine whether the past three years constitute a trend. A Tiger Team appraisal was conducted in November 1989. 
Table C4. Kansas City Plant site data.

\begin{tabular}{|c|c|c|c|c|c|c|c|c|c|c|}
\hline Year & TRC $r$ & LWD r & $\begin{array}{l}\text { Plant } \\
\text { Budget }\end{array}$ & $\begin{array}{l}\text { Safety } \\
\text { Budget }\end{array}$ & $\$ \%$ & $10 * \$ \%$ & $\begin{array}{l}\text { Plant } \\
\text { Staff }\end{array}$ & $\begin{array}{l}\text { Safety } \\
\text { Staff }\end{array}$ & FTE \% & $10 *$ FTE\% \\
\hline & & & & & & & & & & \\
\hline 1980 & 1.1 & 1.3 & $\$ 285.4$ & $\$ 0.97$ & 0.34 & 3.41 & 6153 & 18 & 0.29 & 2.93 \\
\hline 1981 & 1.2 & 2.1 & $\$ 343.4$ & $\$ 1.00$ & 0.29 & 2.90 & 6573 & 17 & 0.26 & 2.59 \\
\hline 1982 & 0.9 & 1.6 & $\$ 402.4$ & $\$ 1.08$ & 0.27 & 2.69 & 6767 & 19 & 0.28 & 2.81 \\
\hline 1983 & 0.8 & 6.0 & $\$ 457.2$ & $\$ 1.19$ & 0.26 & 2.61 & 7168 & 19 & 0.27 & 2.65 \\
\hline 1984 & 0.8 & 3.9 & $\$ 481.1$ & $\$ 1.41$ & 0.29 & 2.93 & 7501 & 19 & 0.25 & 2.53 \\
\hline 1985 & 0.5 & 1.6 & $\$ 520.4$ & $\$ 1.76$ & 0.34 & 3.39 & 7690 & 20 & 0.26 & 2.60 \\
\hline 1986 & 0.6 & 5.2 & $\$ 517.9$ & $\$ 2.06$ & 0.40 & 3.98 & 7127 & 19 & 0.27 & 2.67 \\
\hline 1987 & 0.8 & 1.6 & $\$ 508.9$ & $\$ 1.48$ & 0.29 & 2.90 & 6847 & 18 & 0.26 & 2.63 \\
\hline 1988 & 0.9 & 2.7 & $\$ 627.0$ & $\$ 2.19$ & 0.35 & 3.50 & 6993 & 20 & 0.29 & 2.86 \\
\hline 1989 & 1.4 & 5.4 & $\$ 588.6$ & $\$ 3.27$ & 0.56 & 5.56 & 6571 & 26 & 0.40 & 3.96 \\
\hline 1990 & 2.4 & 9.4 & $\$ 541.1$ & $\$ 4.71$ & 0.87 & 8.70 & 6219 & 35 & 0.56 & 5.63 \\
\hline & & & $M \$$ & $M \$$ & & & & & & \\
\hline Avg $80-84$ & 0.96 & 2.98 & $\$ 393.9$ & $\$ 1.13$ & 0.29 & 2.91 & 6832.4 & 18.4 & 0.27 & 2.70 \\
\hline Avg $85-89$ & 0.84 & 3.30 & $\$ 552.6$ & $\$ 2.15$ & 0.39 & 3.87 & 7045.6 & 20.6 & 0.29 & 2.94 \\
\hline Avg $80-89$ & 0.90 & 3.14 & $\$ 473.2$ & $\$ 1.64$ & 0.34 & 3.39 & 6939.0 & 19.5 & 0.28 & 2.82 \\
\hline
\end{tabular}


Table C4. (Cont.)

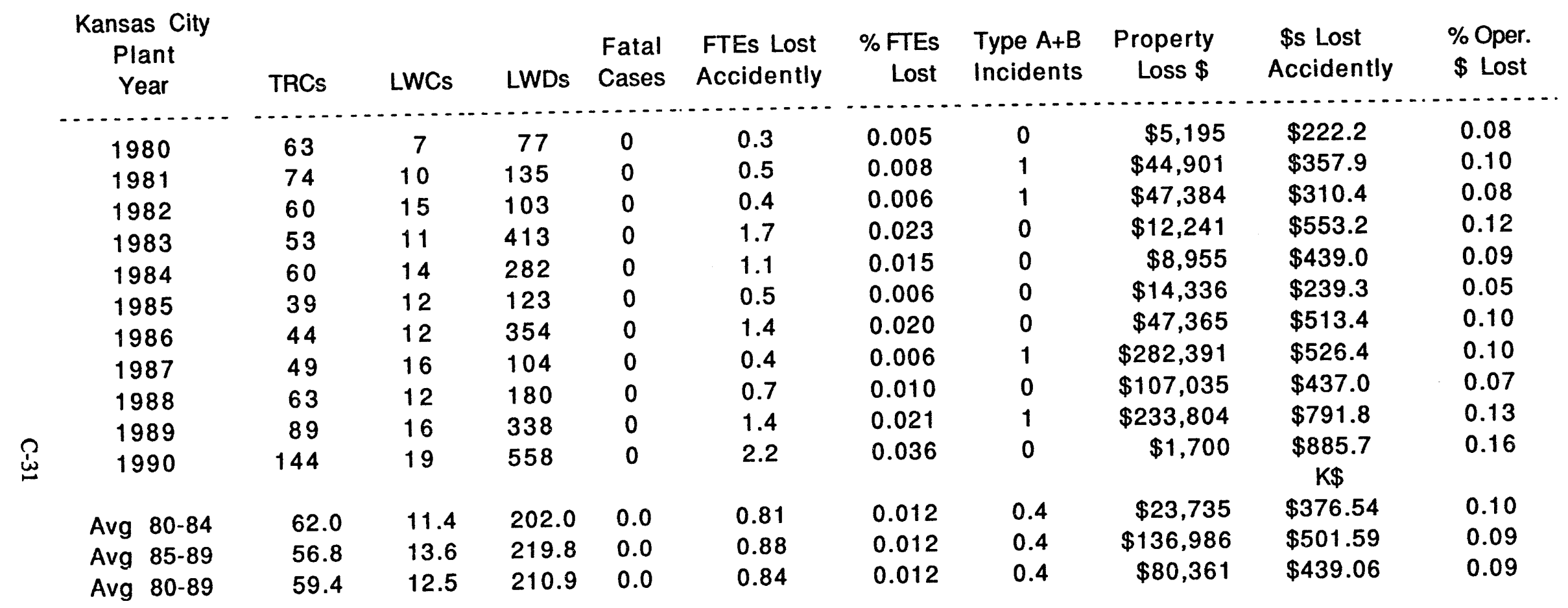


Table C4. (Cont.)

\begin{tabular}{|c|c|c|c|c|c|c|c|}
\hline $\begin{array}{c}\text { Kansas City } \\
\text { Plant } \\
\text { Year }\end{array}$ & $\begin{array}{c}\text { Person } \\
\text { Rem }\end{array}$ & $\begin{array}{c}\$ 1000 \text { per } \\
\text { ManRem }\end{array}$ & $\begin{array}{c}\text { Acc. + Rad. } \\
\$ \text { Lost }\end{array}$ & $\begin{array}{l}\text { Acc. + Rad. } \\
\% \text { Lost }\end{array}$ & $\begin{array}{l}\text { Worker's } \\
\text { Comp costs }\end{array}$ & $\begin{array}{l}\text { Total } \\
\% \text { Lost }\end{array}$ & $\begin{array}{c}\text { Worker's Comp } \\
\% \text { of Oper. } \$\end{array}$ \\
\hline & & & & & & & $\cdots$ \\
\hline 1980 & 2 & $\$ 2$ & $\$ 224$ & 0.08 & $\$ 28.1$ & 0.09 & 0.010 \\
\hline 1981 & 4 & $\$ 4$ & $\$ 362$ & 0.11 & $\$ 63.0$ & 0.12 & 0.018 \\
\hline 1982 & 1 & $\$ 1$ & $\$ 311$ & 0.08 & $\$ 55.4$ & 0.09 & 0.014 \\
\hline 1983 & 1 & $\$ 1$ & $\$ 554$ & 0.12 & $\$ 107.6$ & 0.14 & 0.024 \\
\hline 1984 & 4 & $\$ 4$ & $\$ 443$ & 0.09 & $\$ 78.5$ & 0.11 & 0.016 \\
\hline 1985 & 11 & $\$ 11$ & $\$ 250$ & 0.05 & $\$ 142.1$ & 0.08 & 0.027 \\
\hline 1986 & 1 & $\$ 1$ & $\$ 514$ & 0.10 & $\$ 295.4$ & 0.16 & 0.057 \\
\hline 1987 & 0 & $\$ 0$ & $\$ 526$ & 0.10 & $\$ 51.2$ & 0.11 & 0.010 \\
\hline 1988 & 1 & $\$ 1$ & $\$ 438$ & 0.07 & $\$ 96.4$ & 0.09 & 0.015 \\
\hline 1989 & 0 & $\$ 0$ & $\$ 792$ & 0.13 & $\$ 127.3$ & 0.16 & 0.022 \\
\hline \multirow[t]{2}{*}{1990} & 0 & $\$ 0$ & $\$ 886$ & 0.16 & $\$ 146.0$ & 0.19 & 0.027 \\
\hline & & $\mathrm{K} \$$ & $\mathrm{~K} \$$ & & $\mathrm{~K} \$$ & & \\
\hline Avg $80-84$ & 2.4 & $\$ 2$ & $\$ 379$ & 0.09 & $\$ 66.5$ & 0.11 & 0.016 \\
\hline Avg $85-89$ & 2.6 & $\$ 3$ & $\$ 504$ & 0.09 & $\$ 142.5$ & 0.12 & 0.026 \\
\hline Avg $80-89$ & 2.5 & $\$ 3$ & $\$ 442$ & 0.09 & $\$ 104.5$ & 0.11 & 0.021 \\
\hline
\end{tabular}




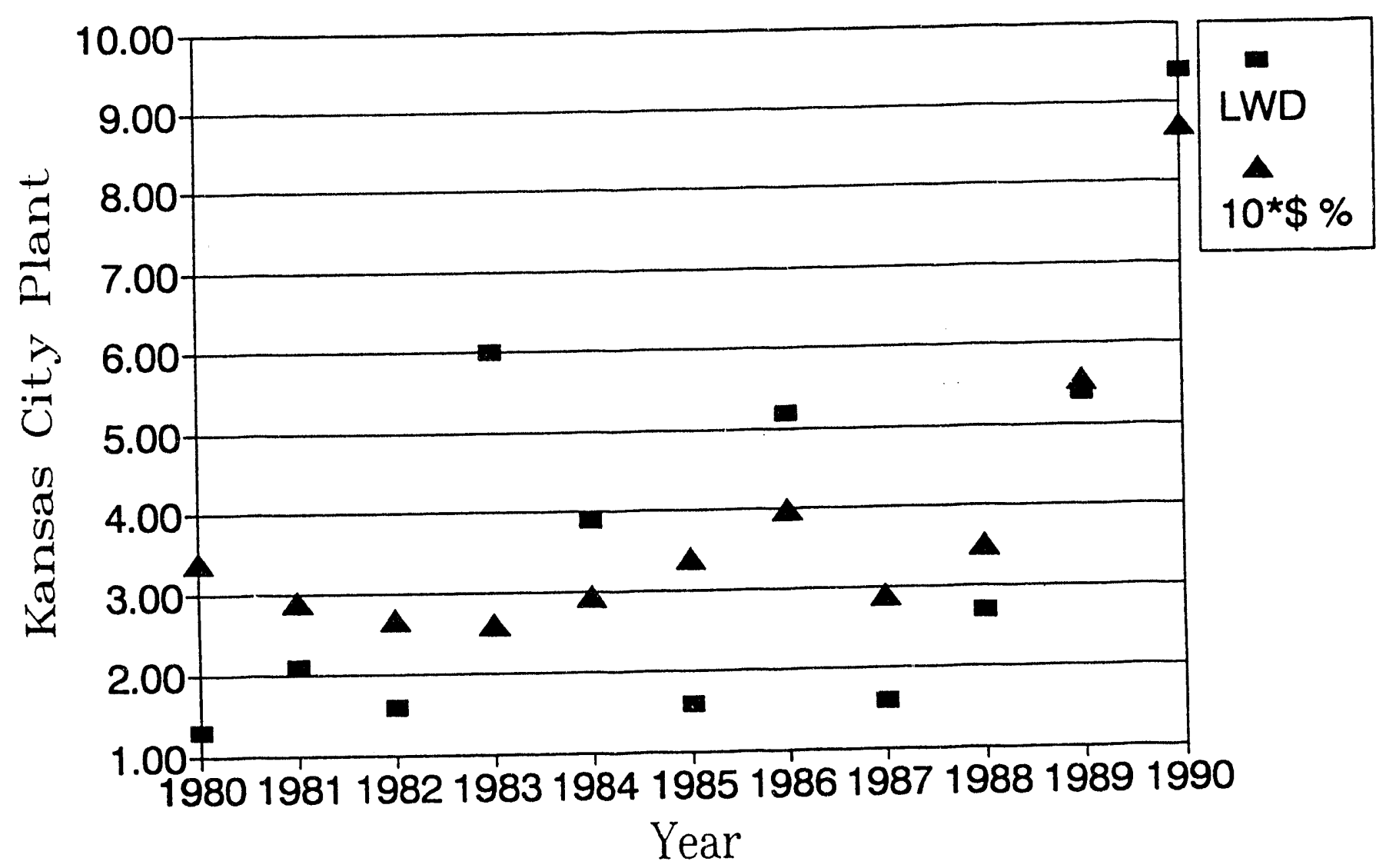

Figure C4.1. Lost workdays per $200 \mathrm{k}$ man-hr, 10 times safety budget percentage. 


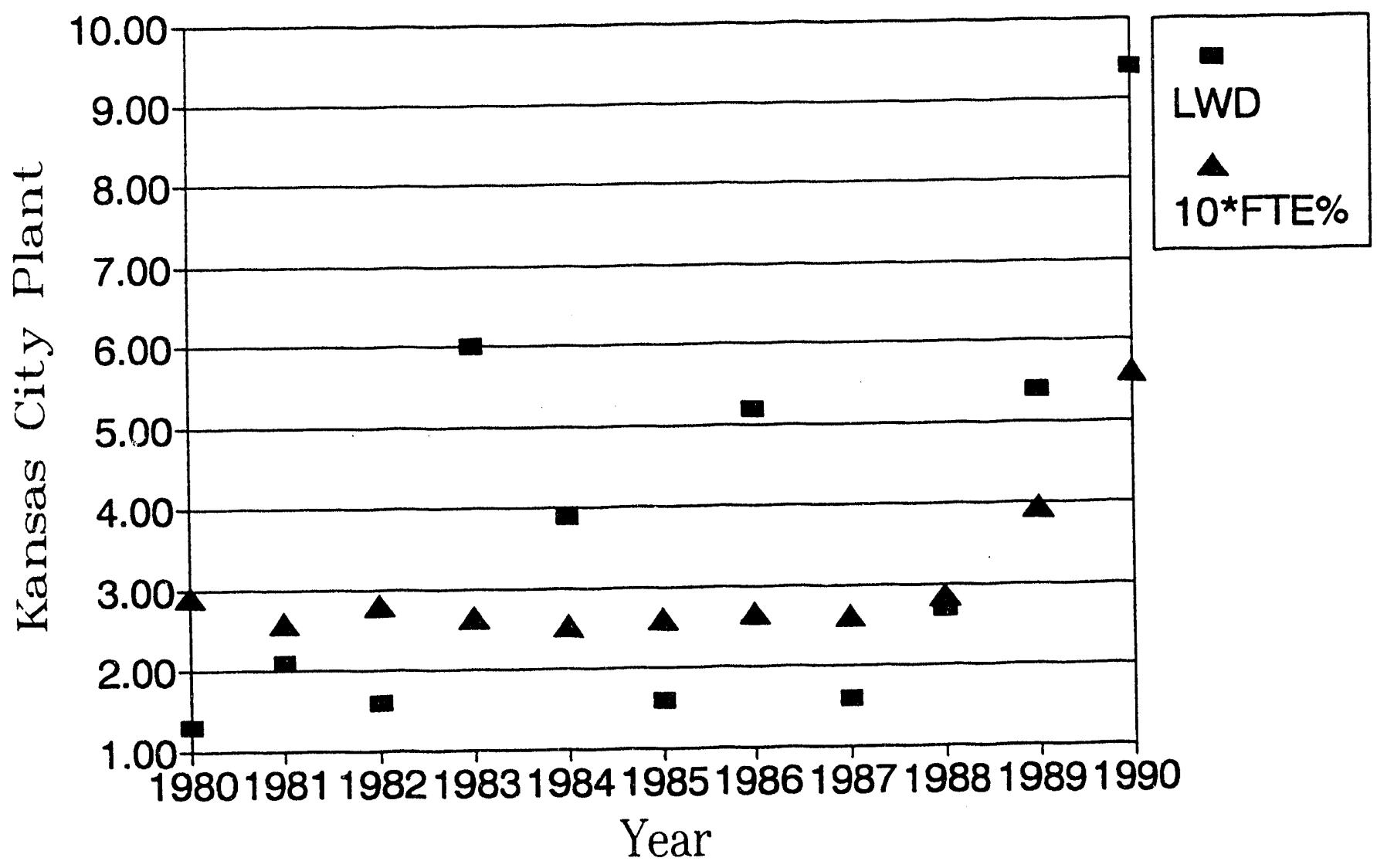

Figure C4.2. Lost workdays per $200 \mathrm{k}$ man-hr, 10 times safety manpower percentage. 


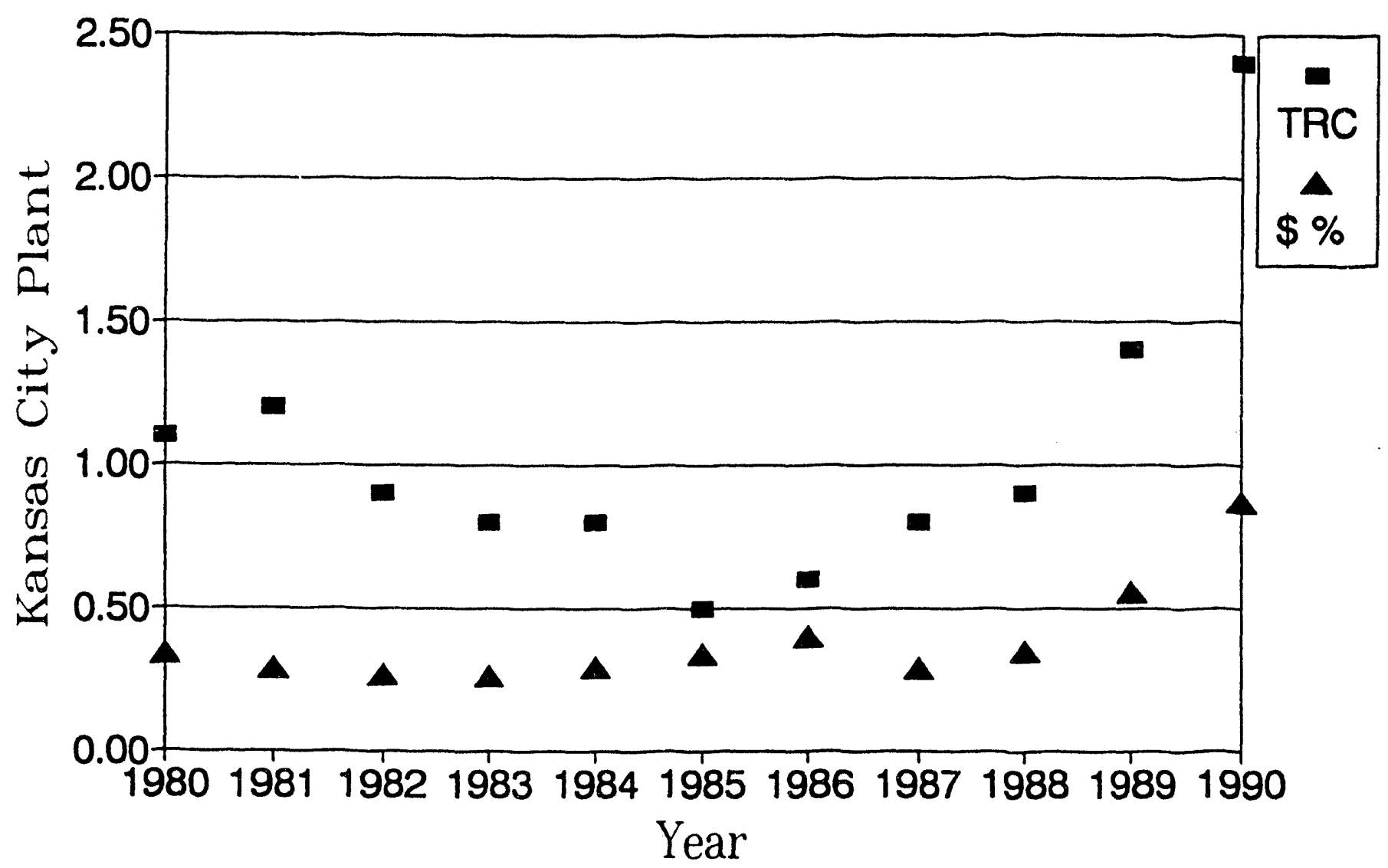

Figure C4.3. Total reportable case rate, percent of Plant budget spent on safety. 


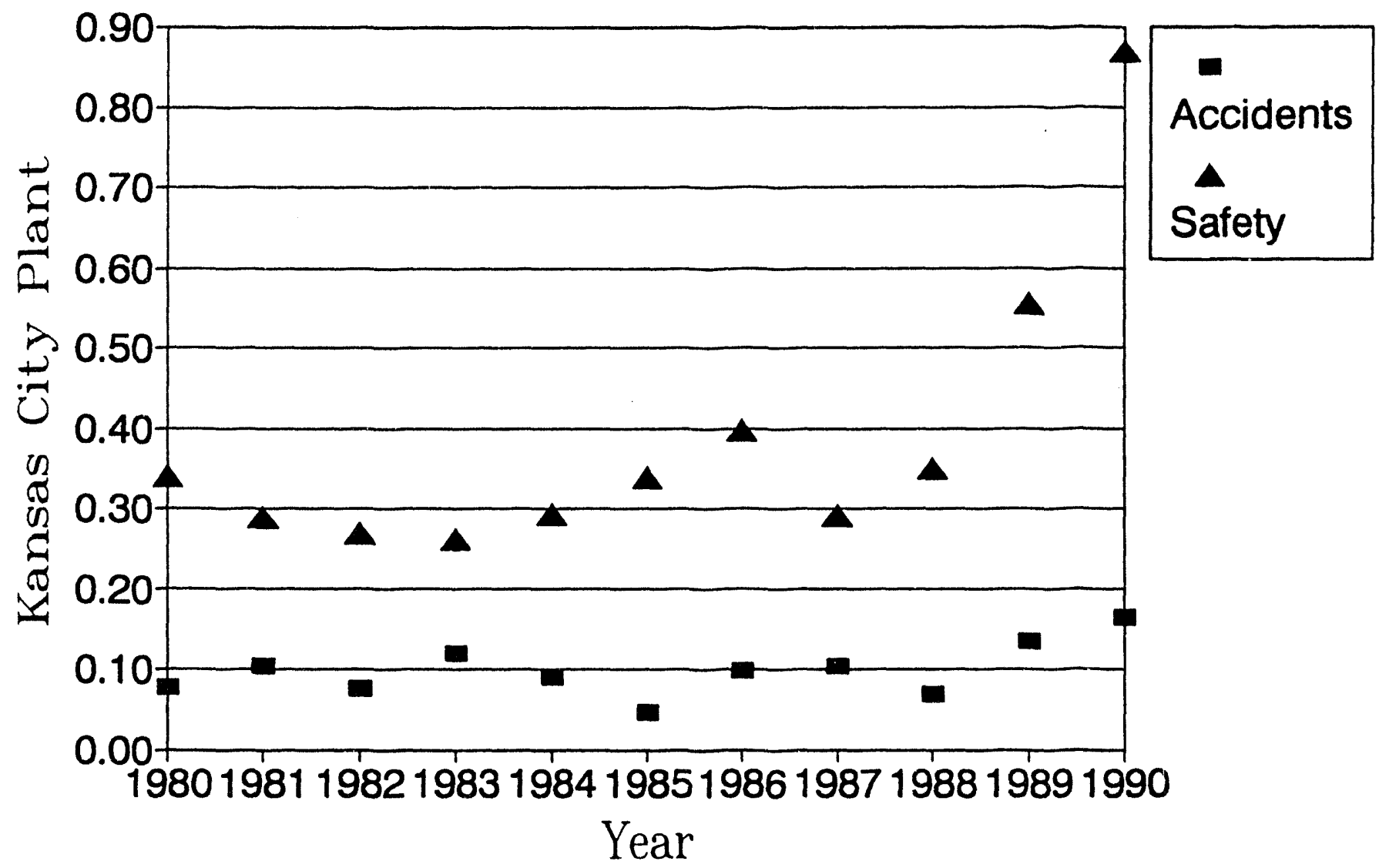

Figure C4.4. Percent of budget lost accidentally, percent of Plant budget spent on safety. 


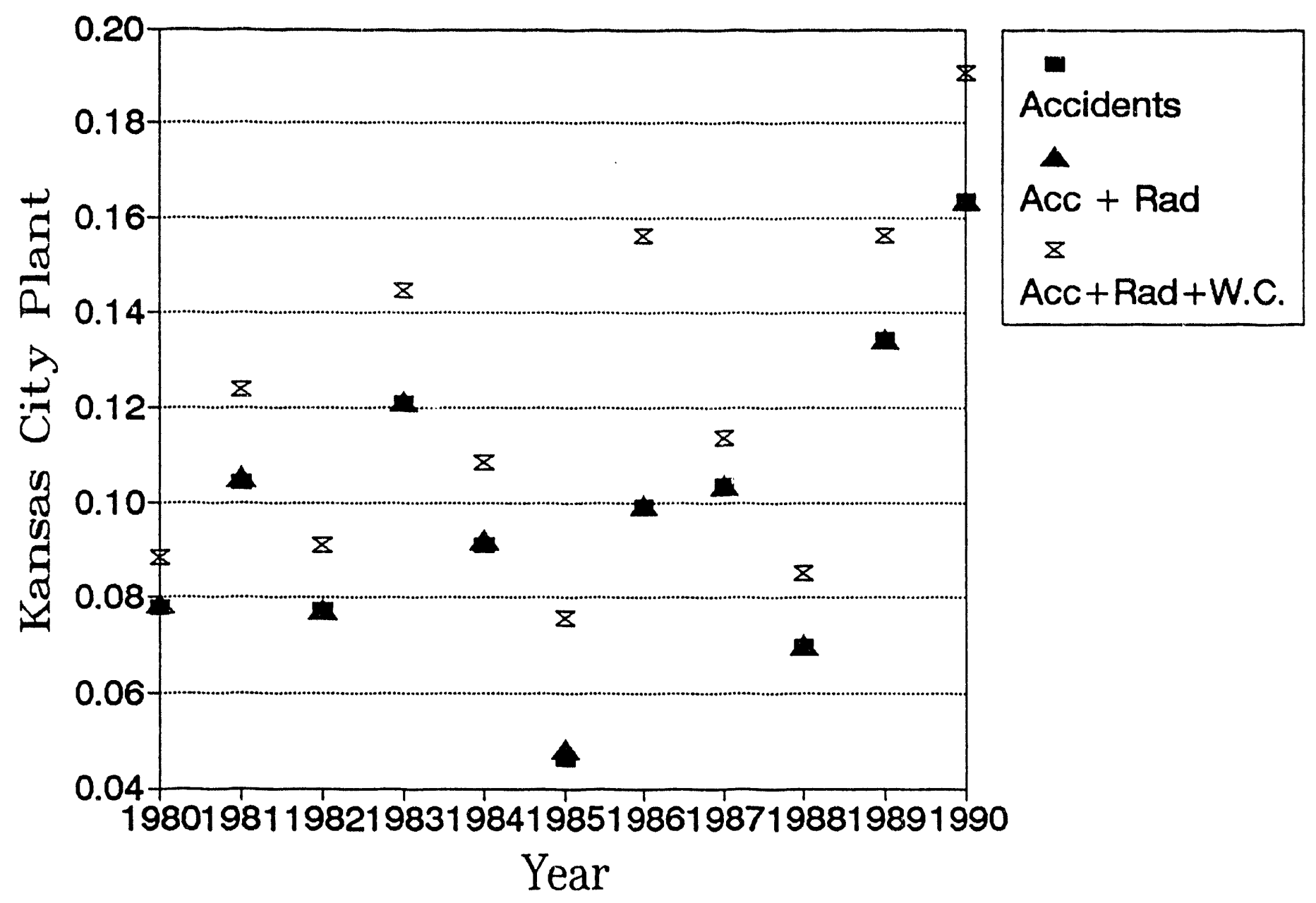

Figure C4.5. Percent of operating budget lost by year, including actual accident losses, estimated radiological consequences, and reported worker's compensation expenditures. 


\section{C5. LANL}

LANL is a multiprogram national $R \& D$ laboratory. The Laboratory was unable to provide safety budget data for 1980 and 1981. The figures used were derived from projections based on following years. There was a Tiger Team appraisal in November 1991. The site was unable to retrieve worker's compensation data prior to 1985. 
Table C5. LANL site data.

\begin{tabular}{|c|c|c|c|c|c|c|c|c|c|c|}
\hline Year & TRC r & LWD r & $\begin{array}{c}\text { Lab } \\
\text { Budget }\end{array}$ & $\begin{array}{l}\text { Safety } \\
\text { Budget }\end{array}$ & $\$ \%$ & $10 * \$ \%$ & $\begin{array}{l}\text { Lab } \\
\text { Staff }\end{array}$ & $\begin{array}{c}\text { Safety } \\
\text { Staff }\end{array}$ & FTE \% & 10*FTE\% \\
\hline & & & & & & & & 161 & 240 & 23.99 \\
\hline $\begin{array}{l}1980 \\
1981\end{array}$ & 1.4 & 7.9 & $\$ 383$ & $\$ 5,750$ & 1.50 & 15.01 & 6,836 & $\begin{array}{l}104 \\
170\end{array}$ & 2.40 & $\begin{array}{l}23.99 \\
24.01\end{array}$ \\
\hline $\begin{array}{l}1981 \\
1982\end{array}$ & 1.5 & 7.9 & $\$ 453$ & $\$ 6,800$ & 1.50 & 15.01 & 7,163 & 172 & 2.40 & 24.01 \\
\hline $\begin{array}{l}1982 \\
1983\end{array}$ & 1.9 & 12.9 & $\$ 507$ & $\$ 7,794$ & 1.54 & 15.37 & 7,184 & 178 & 2.48 & 24.78 \\
\hline $\begin{array}{l}1983 \\
1984\end{array}$ & 2.2 & 17.4 & $\$ 552$ & $\$ 8,392$ & 1.52 & 15.20 & 7,104 & 166 & 2.34 & 23.37 \\
\hline $\begin{array}{l}1984 \\
1985\end{array}$ & 3.0 & 18.0 & $\$ 628$ & $\$ 7,696$ & 1.23 & 12.25 & 7,454 & 154 & 2.07 & 20.66 \\
\hline $\begin{array}{l}1985 \\
1986\end{array}$ & 5.1 & 15.9 & $\$ 715$ & $\$ 8,450$ & 1.18 & 11.82 & 7,917 & 160 & 2.02 & 20.21 \\
\hline $\begin{array}{l}1986 \\
1987\end{array}$ & 4.3 & 8.7 & $\$ 786$ & $\$ 9,934$ & 1.26 & 12.64 & 8,011 & 179 & 2.23 & 22.34 \\
\hline $\begin{array}{l}1987 \\
1988\end{array}$ & 4.1 & 13.9 & $\$ 844$ & $\$ 11,403$ & 1.35 & 13.51 & 7,997 & 190 & 2.38 & 23.76 \\
\hline 1989 & $\begin{array}{l}2.8 \\
3.2\end{array}$ & $\begin{array}{l}10.4 \\
15.9\end{array}$ & $\begin{array}{l}\$ 893 \\
\$ 917\end{array}$ & $\$ 14,478$ & 1.62 & 16.21 & 7,788 & 205 & 2.63 & 26.32 \\
\hline 1990 & 3.6 & 28.0 & $\begin{array}{l}\$ 917 \\
\$ 950\end{array}$ & $\$ 16,798$ & 1.83 & $\begin{array}{l}18.32 \\
23.17\end{array}$ & 7,811 & 227 & 2.91 & 29.06 \\
\hline & & & $M \$$ & $\begin{array}{c}\$ 22,016 \\
K \$\end{array}$ & 2.32 & 23.17 & 7,820 & 252 & 3.22 & 32.23 \\
\hline $\begin{array}{ll}\text { Avg } & 80-84 \\
\text { Avg } & 85-89\end{array}$ & 2.00 & 12.82 & $\$ 505$ & $\$ 7,286$ & 1.46 & 14.57 & 7,148 & 167 & 2.34 & 23.36 \\
\hline $\begin{array}{ll}\text { Avg } & 85-89 \\
\text { Avg } & 80-89\end{array}$ & 3.90 & 12.96 & $\$ 831$ & $\$ 12,213$ & 1.45 & 14.50 & 7,905 & 192 & 2.43 & 24.34 \\
\hline & 2.95 & 12.89 & $\$ 668$ & $\$ 9,750$ & 1.45 & 14.54 & 7,527 & 180 & 2.39 & 23.85 \\
\hline
\end{tabular}


Table C5. (Cont.)

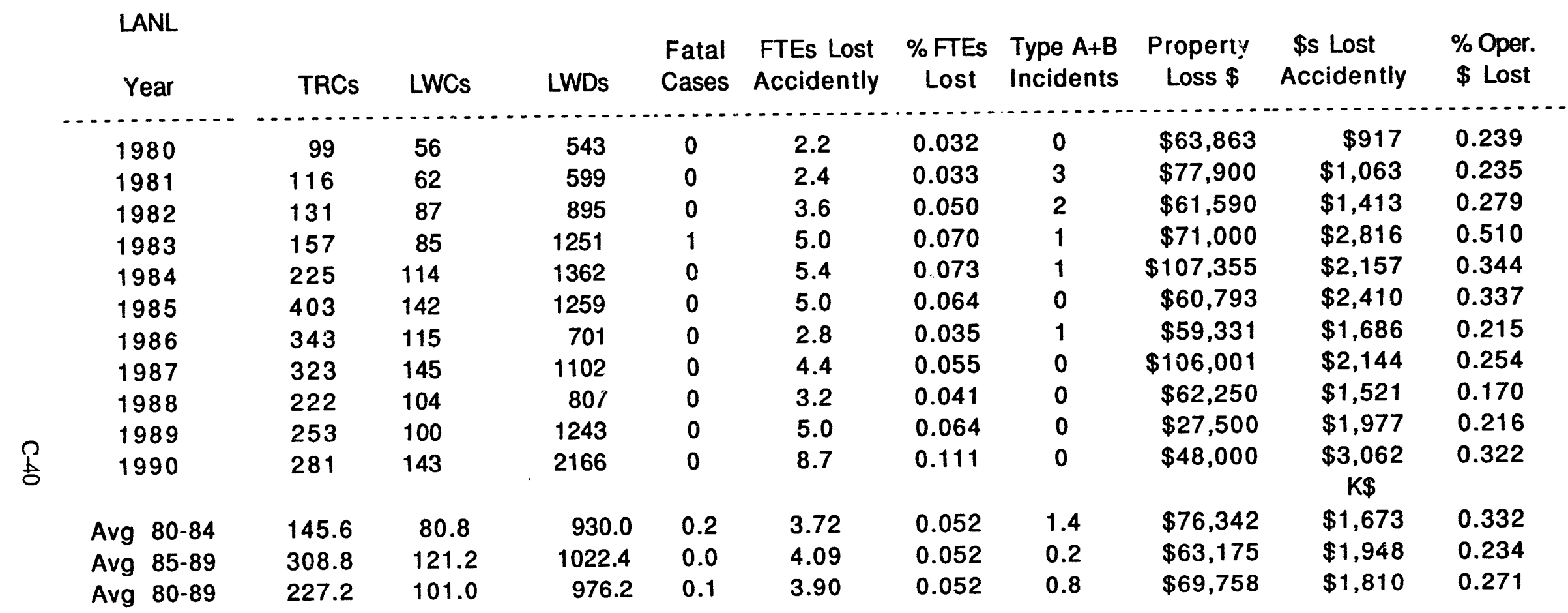


Table C5. (Cont.)

\begin{tabular}{|c|c|c|c|c|c|c|c|}
\hline LANL & $\begin{array}{l}\text { Person } \\
\text { Rem }\end{array}$ & $\begin{array}{r}\$ 1000 \text { per } \\
\text { ManRem }\end{array}$ & $\begin{array}{c}\text { Acc. + Rad. } \\
\text { \$ Lost }\end{array}$ & $\begin{array}{c}\text { Acc. + Rad. } \\
\% \text { Lost }\end{array}$ & $\begin{array}{l}\text { Worker's } \\
\text { Comp Costs }\end{array}$ & $\begin{array}{l}\text { Total } \\
\% \text { Lost }\end{array}$ & $\begin{array}{c}\text { Worker's Comp } \\
\% \text { of Oper. } \$\end{array}$ \\
\hline & & & & & & & \\
\hline $\begin{array}{l}1980 \\
1981\end{array}$ & 427 & $\$ 427$ & $\$ 1,344$ & 0.35 & $n / a$ & & \\
\hline $\begin{array}{l}1981 \\
1982\end{array}$ & 630 & $\$ 630$ & $\$ 1,693$ & 0.37 & $n / a$ & & \\
\hline $\begin{array}{l}1982 \\
1983\end{array}$ & 690 & $\$ 690$ & $\$ 2,103$ & 0.41 & $n / a$ & & \\
\hline $\begin{array}{l}1983 \\
1984\end{array}$ & 700 & $\$ 700$ & $\$ 3,516$ & 0.64 & $\mathrm{n} / \mathrm{a}$ & & \\
\hline $\begin{array}{l}1984 \\
1985\end{array}$ & $\begin{array}{l}808 \\
714\end{array}$ & $\$ 808$ & $\$ 2,965$ & 0.47 & $n / a$ & & \\
\hline 1986 & $\begin{array}{l}714 \\
535\end{array}$ & $\$ 714$ & $\$ 3,124$ & 0.44 & $\$ 775.0$ & 0.55 & 0.108 \\
\hline $\begin{array}{l}1987 \\
1988\end{array}$ & $\begin{array}{l}535 \\
376\end{array}$ & $\begin{array}{l}\$ 535 \\
\$ 376\end{array}$ & $\$ 2,221$ & 0.28 & $\$ 795.2$ & 0.38 & 0.101 \\
\hline $\begin{array}{l}1988 \\
1989\end{array}$ & 370 & $\begin{array}{l}\$ 376 \\
\$ 370\end{array}$ & $\begin{array}{l}\$ 2,520 \\
\$ 1,891\end{array}$ & 0.30 & $\$ 806.8$ & 0.39 & 0.096 \\
\hline $\begin{array}{l}1989 \\
1990\end{array}$ & 302 & $\$ 302$ & $\begin{array}{l}\$ 1,891 \\
\$ 2,279\end{array}$ & 0.21 & $\$ 335.8$ & 0.25 & 0.038 \\
\hline 1990 & 213 & $\$ 213$ & $\begin{array}{l}\$ 2,279 \\
\$ 3,275\end{array}$ & 0.25 & $\$ 538.7$ & 0.31 & 0.059 \\
\hline & & $\mathrm{K} \$$ & $\mathrm{~K} \$$ & 0.34 & $\begin{array}{c}\$ 923.1 \\
\mathrm{~K} \$\end{array}$ & 0.44 & 0.097 \\
\hline $\begin{array}{l}\text { Avg } 80-84 \\
\text { Avg } 85-89\end{array}$ & 651 & $\$ 651$ & $\$ 2,324$ & 0.45 & & & \\
\hline $\begin{array}{ll}\text { Avg } & 85-89 \\
\text { Avg } & 80-89\end{array}$ & 459 & $\$ 459$ & $\$ 2,407$ & 0.30 & $\$ 650.3$ & 0.37 & 0.078 \\
\hline Avg $80-89$ & 555 & $\$ 555$ & $\$ 2,366$ & 0.37 & & & \\
\hline
\end{tabular}




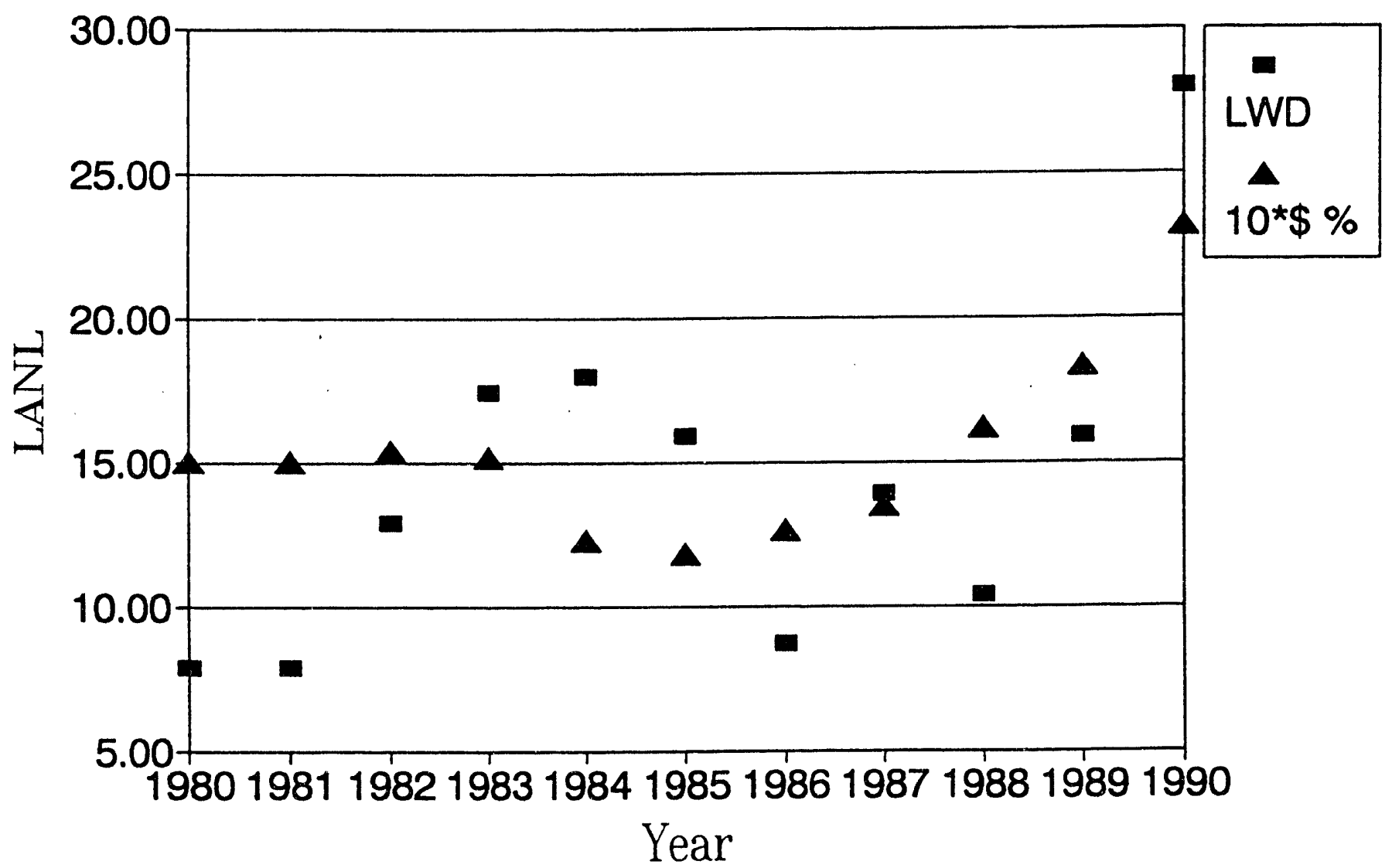

Figure C5.1. Lost workdays per $200 \mathrm{k}$ man-hr, 10 times safety budget percentage. 


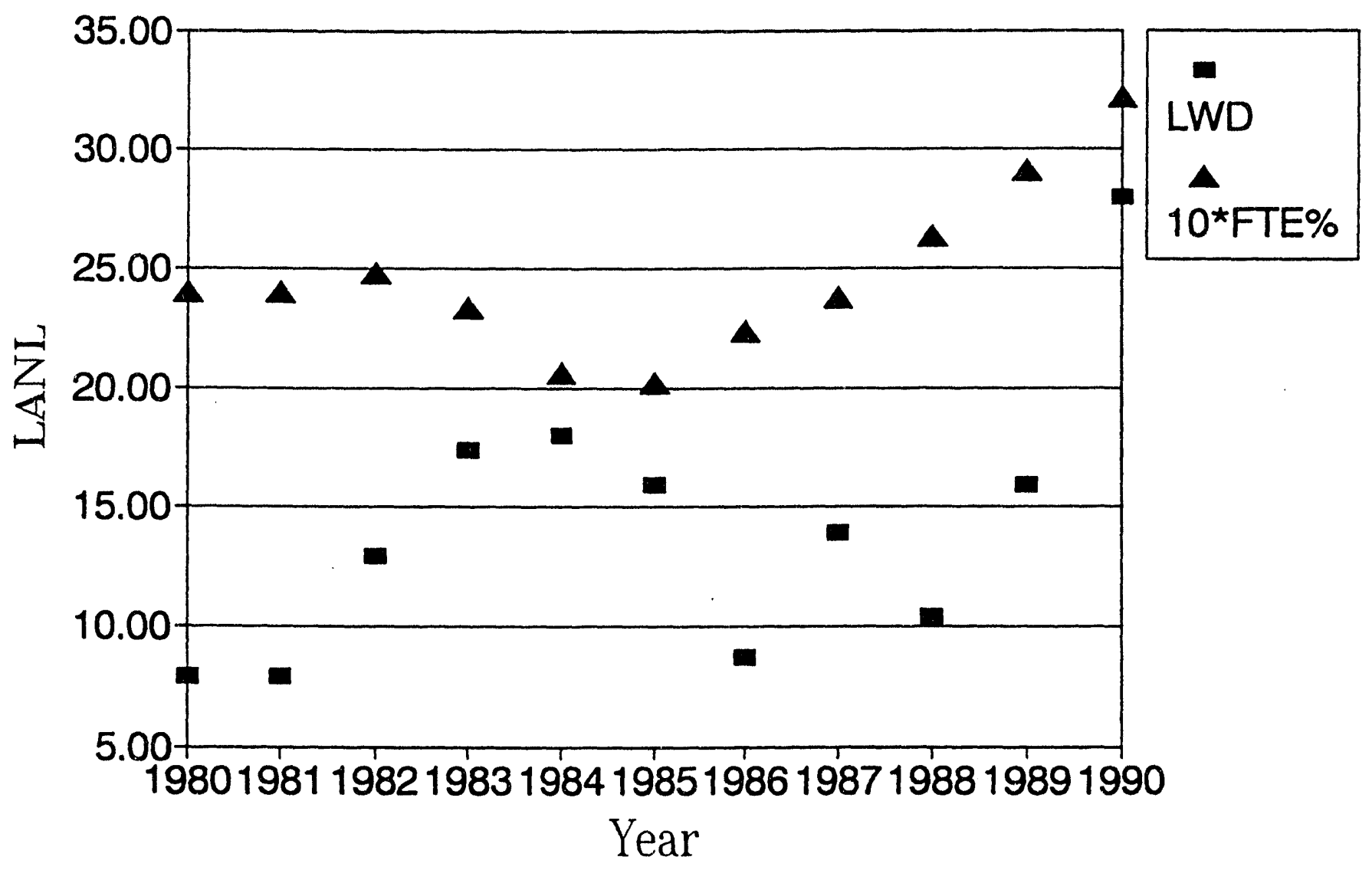

Figure C5.2. Lost workdays per 200k man-hr, 10 times safety manpower percentage. 


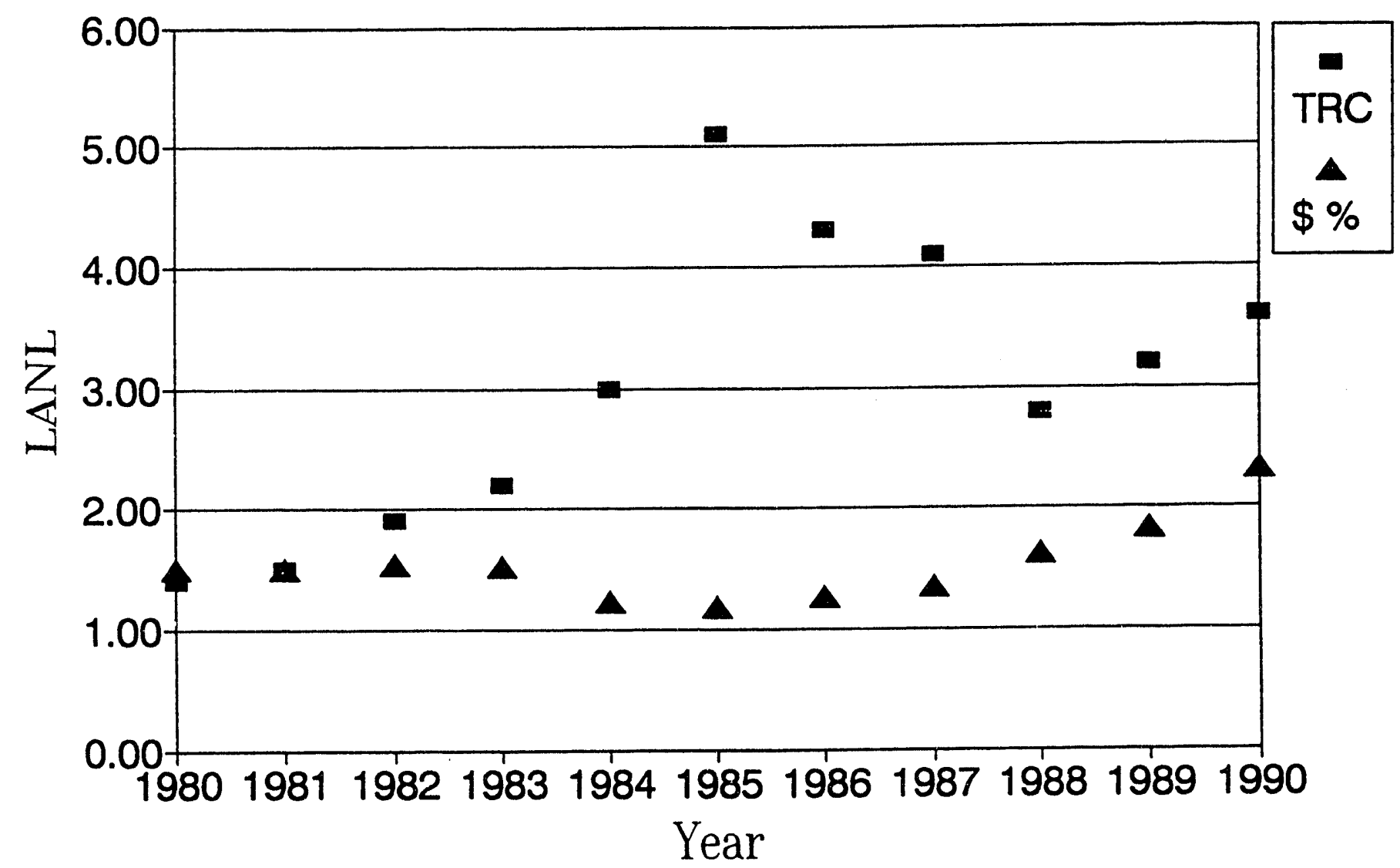

Figure C5.3. Total reportable case rate, percent of Laboratory budget spent on safety. 


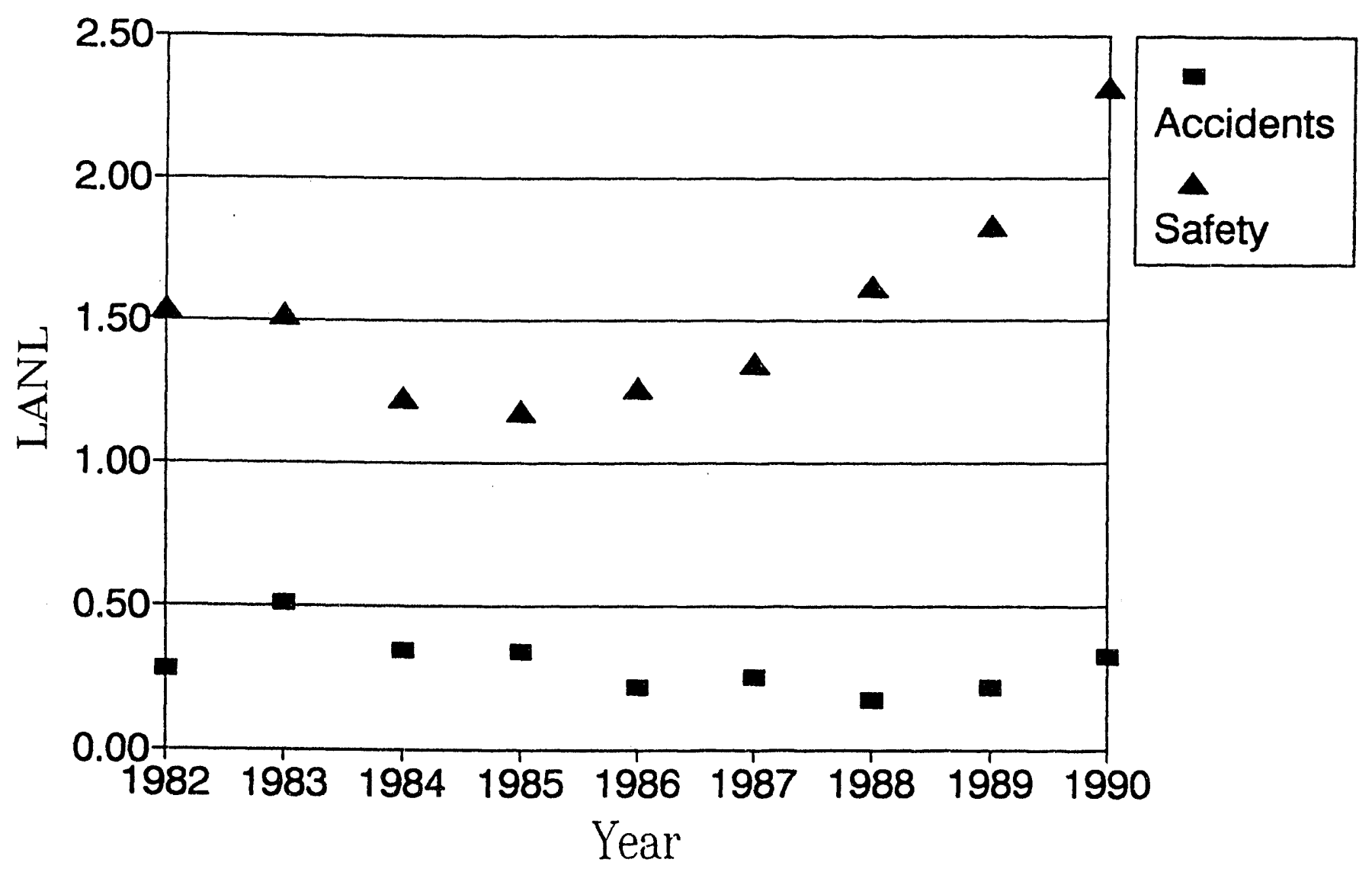

Figure C5.4. Percent of budget lost accidentally, percent of Laboratory budget spent on safety. 
C6. LBL

LBL is an R\&D laboratory, largely accelerator focused. Plant Services were separated out of the Laboratory's safety data population in 1989. Those figures have been integrated back into the totals for this comparison. A Tiger Team appraisal was conducted in January 1991. 
Table C6. LBL site data.

\begin{tabular}{|c|c|c|c|c|c|c|c|c|c|c|}
\hline Year & TRC r & LWD r & $\begin{array}{c}\text { Lab } \\
\text { Budget }\end{array}$ & $\begin{array}{l}\text { Safety } \\
\text { Budget }\end{array}$ & $\$ \%$ & $10 * \$ \%$ & $\begin{array}{l}\text { Lab } \\
\text { Staff }\end{array}$ & $\begin{array}{l}\text { Safety } \\
\text { Staff }\end{array}$ & FTE \% & $10^{\star}$ FTE $\%$ \\
\hline 1980 & 1.6 & & & $\$ 2.39$ & 1.66 & 16.62 & 2795 & 58 & 2.08 & 20.75 \\
\hline 1981 & 1.6 & 17.7 & $\$ 144.0$ & $\$ 2.58$ & 1.79 & 17.90 & 2893 & 60 & 2.07 & 20.74 \\
\hline 1982 & 2.1 & 26.3 & $\$ 138.3$ & $\$ 1.98$ & 1.43 & 14.30 & 2644 & 40 & 1.51 & 15.13 \\
\hline 1983 & 2.1 & 22.3 & $\$ 143.5$ & $\$ 2.01$ & 1.40 & 14.01 & 2619 & 41 & 1.57 & 15.65 \\
\hline 1984 & 1.8 & 18.9 & $\$ 165.0$ & $\$ 2.56$ & 1.55 & 15.53 & 2762 & 43 & 1.56 & 15.57 \\
\hline 1985 & 1.7 & 16.3 & $\$ 168.6$ & $\$ 2.54$ & 1.51 & 15.08 & 2686 & 40 & 1.49 & 14.89 \\
\hline 1986 & 2.7 & 26.1 & $\$ 169.4$ & $\$ 2.77$ & 1.64 & 16.36 & 2464 & 40 & 1.62 & 16.23 \\
\hline 1987 & 2.6 & 25.5 & $\$ 174.5$ & $\$ 3.04$ & 1.74 & 17.40 & 2426 & 46 & 1.90 & 18.96 \\
\hline 1988 & 2.0 & 16.6 & $\$ 183.2$ & $\$ 3.25$ & 1.78 & 17.76 & 2483 & 46 & 1.85 & 18.53 \\
\hline 1989 & 3.0 & 10.7 & $\$ 193.2$ & $\$ 3.49$ & 1.81 & 18.08 & 2578 & 47 & 1.82 & 18.23 \\
\hline 1990 & 3.0 & 27.0 & $\begin{array}{r}\$ 196.0 \\
M \$\end{array}$ & $\begin{array}{r}\$ 4.09 \\
M \$\end{array}$ & 2.09 & 20.88 & 2559 & 49 & 1.91 & 19.15 \\
\hline Avg $80-84$ & 1.84 & 20.08 & $\$ 147.0$ & $\$ 2.30$ & 1.57 & 15.67 & 2742.6 & 48.4 & 1.76 & 17.57 \\
\hline Avg $85-89$ & 2.41 & 19.05 & $\$ 177.8$ & $\$ 3.02$ & 1.69 & 16.94 & 2527.4 & 43.8 & 1.74 & 17.37 \\
\hline Avg $80-89$ & 2.12 & 19.56 & $\$ 162.4$ & $\$ 2.66$ & 1.63 & 16.30 & 2635.0 & 46.1 & 1.75 & 17.47 \\
\hline
\end{tabular}




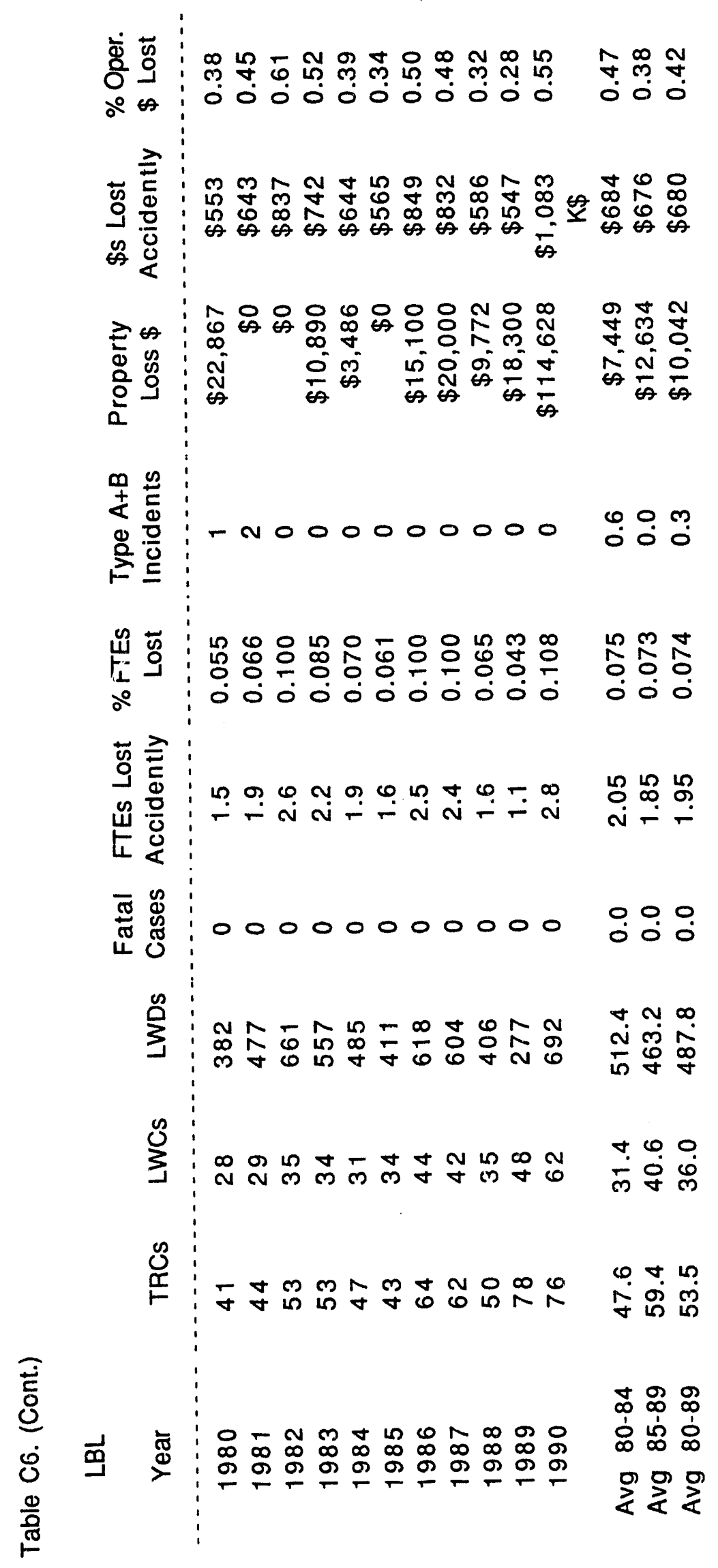


Tabie C6. (Cont.)

\begin{tabular}{cccccccc} 
LBL & $\begin{array}{c}\text { Person } \\
\text { Rem }\end{array}$ & $\begin{array}{c}\$ 1000 \text { per } \\
\text { ManRem }\end{array}$ & $\begin{array}{c}\text { Acc. }+ \text { Rad. } \\
\$ \text { Lost }\end{array}$ & $\begin{array}{c}\text { Acc. }+ \text { Rad. } \\
\% \text { Lost }\end{array}$ & $\begin{array}{c}\text { Worker's } \\
\text { Comp Costs }\end{array}$ & $\begin{array}{c}\text { Total } \\
\% \text { Lost }\end{array}$ & $\begin{array}{c}\text { Worker's Comp } \\
\% \text { of Oper. } \$\end{array}$ \\
\hline 1980 & 91 & $\$ 91$ & $\$ 644$ & 0.45 & $\$ 258.4$ & 0.63 & 0.179 \\
1981 & 31 & $\$ 31$ & $\$ 674$ & 0.47 & $\$ 285.4$ & 0.67 & 0.198 \\
1982 & 35 & $\$ 35$ & $\$ 872$ & 0.63 & $\$ 535.7$ & 1.02 & 0.387 \\
1983 & 26 & $\$ 26$ & $\$ 768$ & 0.54 & $\$ 653.1$ & 0.99 & 0.455 \\
1984 & 38 & $\$ 38$ & $\$ 682$ & 0.41 & $\$ 566.8$ & 0.76 & 0.344 \\
1985 & 46 & $\$ 46$ & $\$ 611$ & 0.36 & $\$ 489.1$ & 0.65 & 0.290 \\
1986 & 27 & $\$ 27$ & $\$ 876$ & 0.52 & $\$ 582.1$ & 0.86 & 0.344 \\
1987 & 30 & $\$ 30$ & $\$ 862$ & 0.49 & $\$ 697.2$ & 0.89 & 0.400 \\
1988 & 27 & $\$ 27$ & $\$ 613$ & 0.33 & $\$ 575.8$ & 0.65 & 0.314 \\
1989 & 16 & $\$ 16$ & $\$ 563$ & 0.29 & $\$ 573.1$ & 0.59 & 0.297 \\
1990 & 14 & $\$ 14$ & $\$ 1,097$ & 0.56 & $\$ 803.3$ & 0.97 & 0.410 \\
Avg $80-84$ & 44 & $\$ 44$ & $\$ 728$ & 0.50 & $\$ 459.9$ & 0.81 & 0.313 \\
Avg $85-89$ & 29 & $\$ 29$ & $\$ 705$ & 0.40 & $\$ 583.5$ & 0.73 & 0.328 \\
Avg $80-89$ & 37 & $\$ 37$ & $\$ 717$ & 0.45 & $\$ 521.7$ & 0.77 & 0.321
\end{tabular}




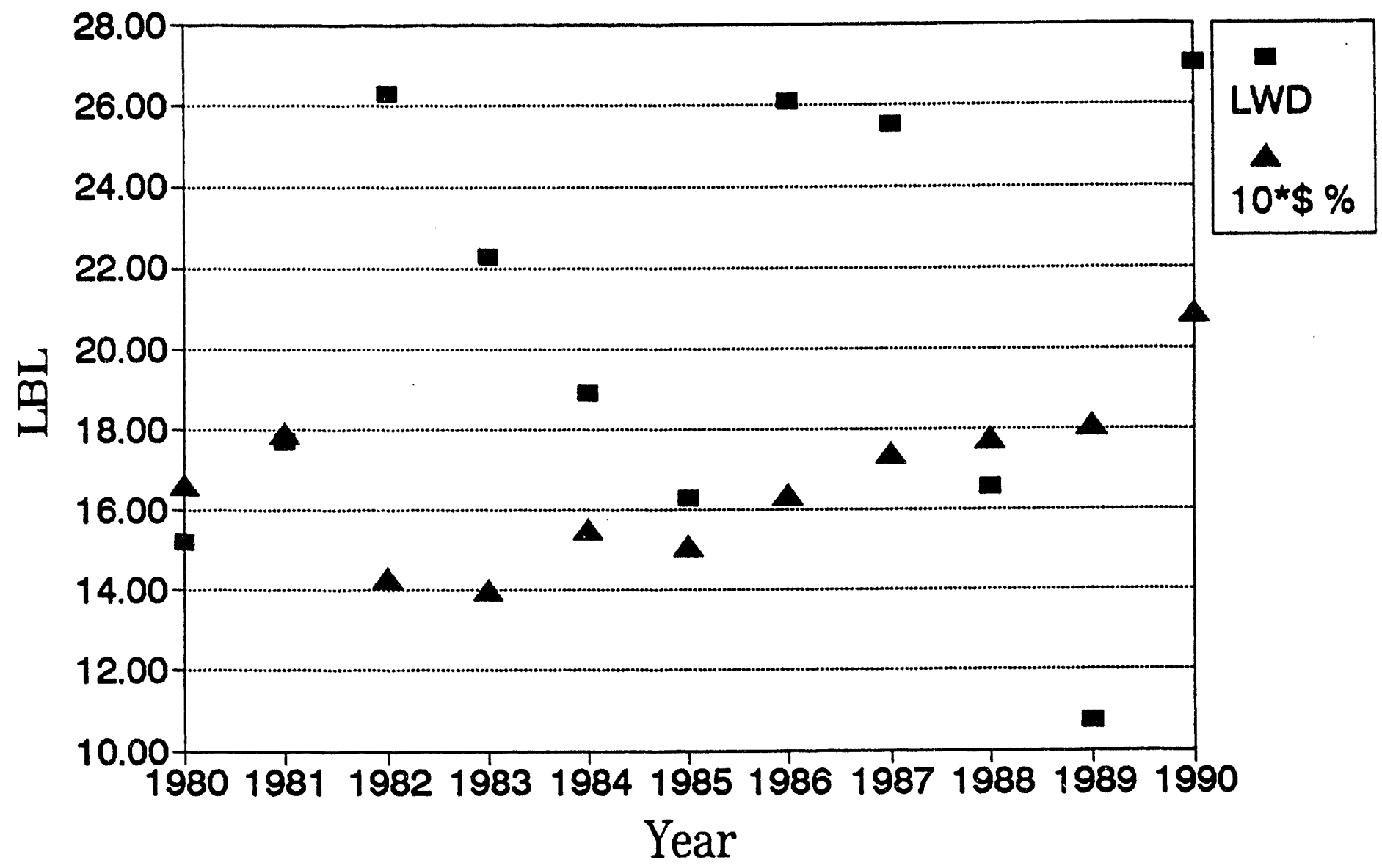

Figure C6.1. Lost workdays per 200k man-hr, 10 times safety budget percentage. 


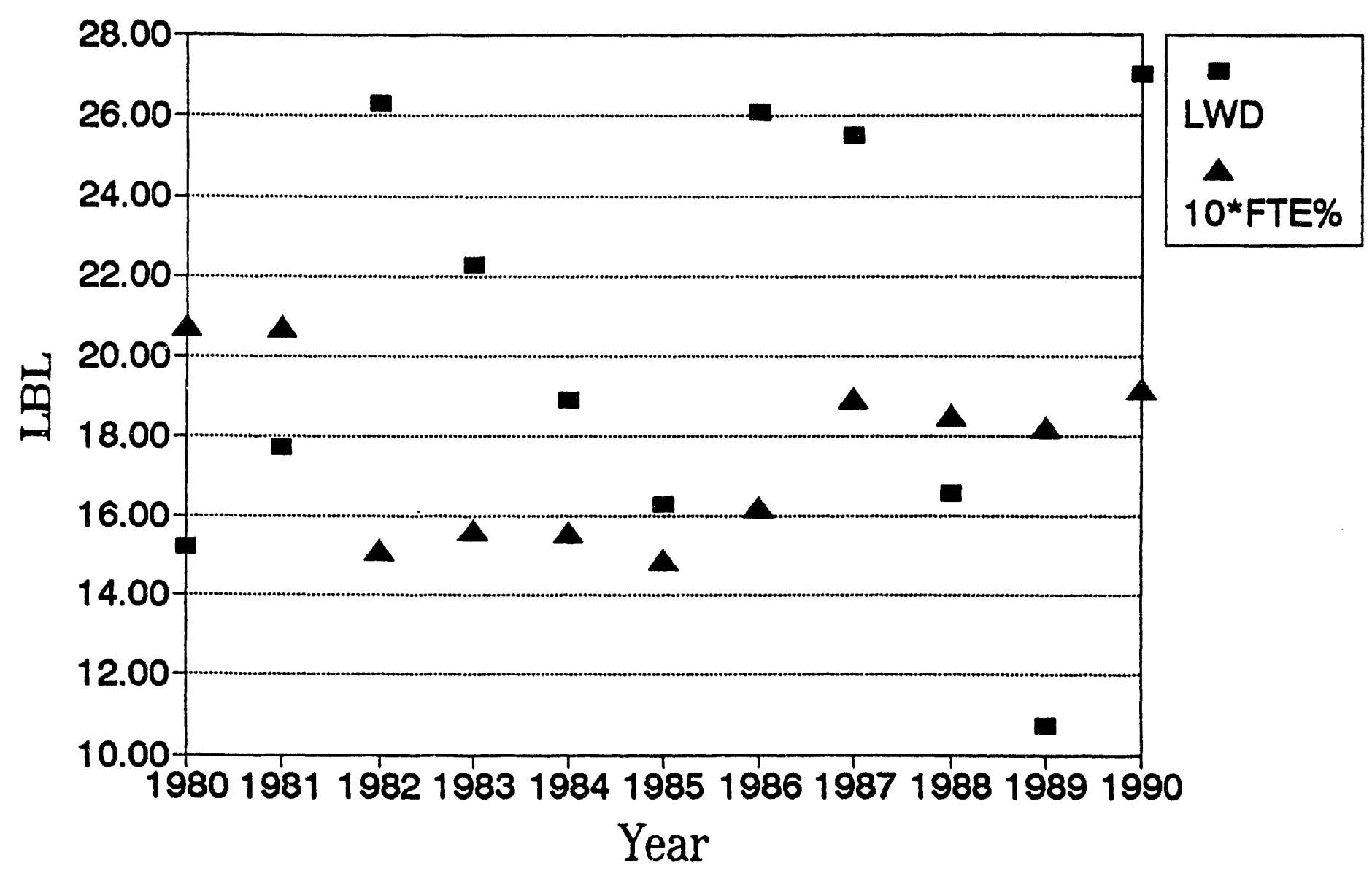

Figure C6.2. Lost workdays per 200k man-hr, 10 times safety manpower percentage. 


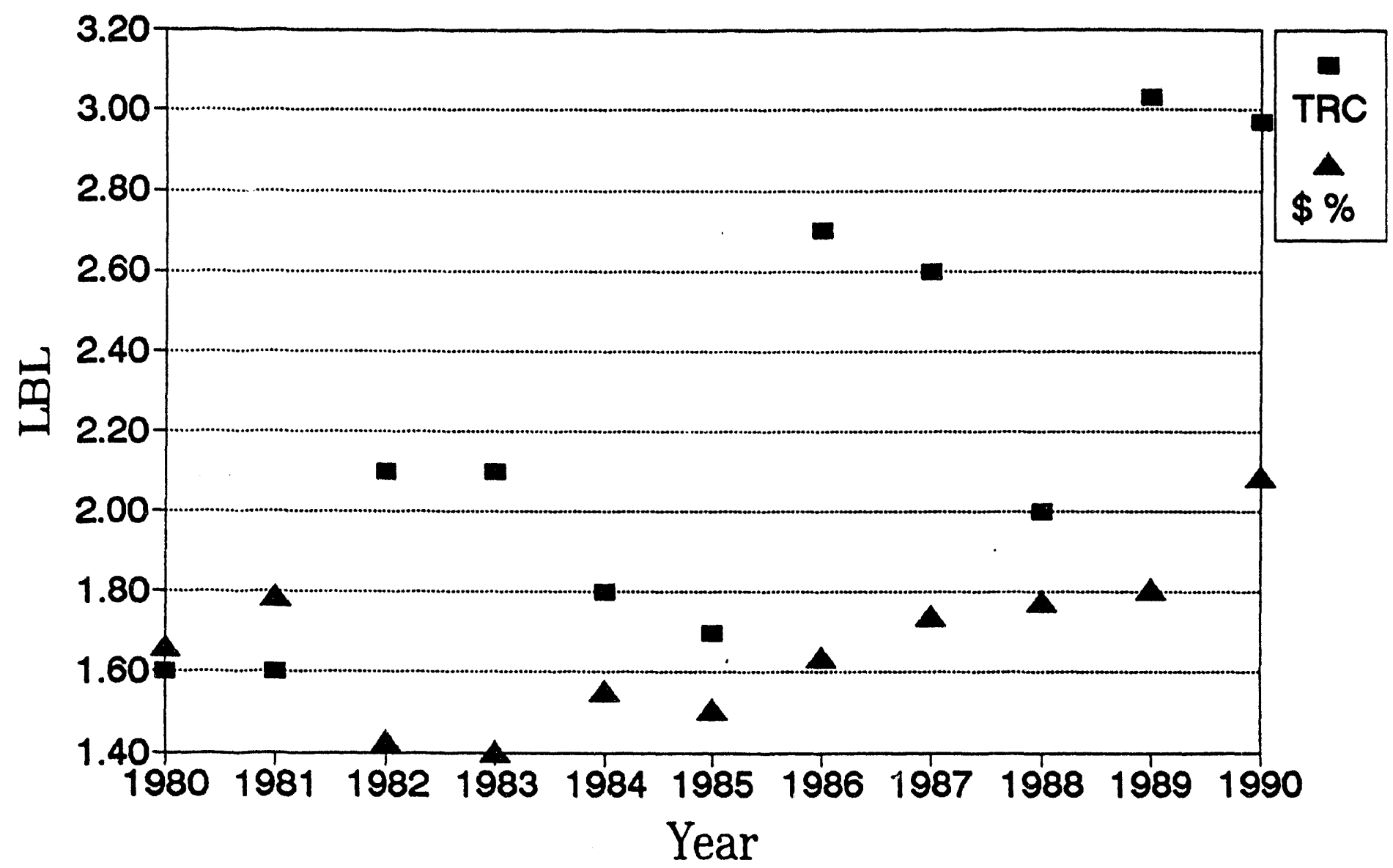

Figure C6.3. Total reportable case rate, percent of Laboratory budget spent on safety. 


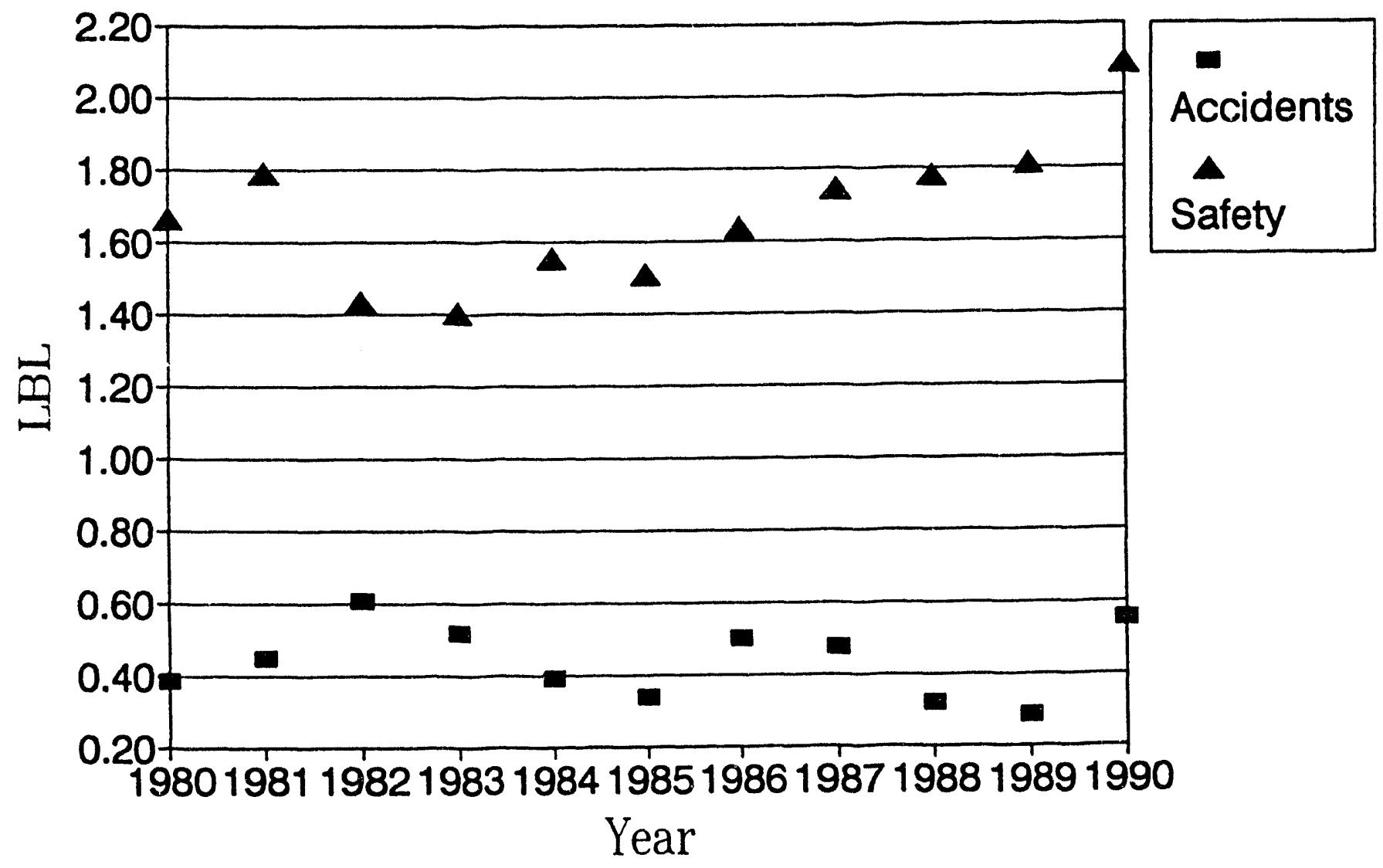

Figure C6.4. Percent of budget lost accidentally, percent of Laboratory budget spent on safety. 


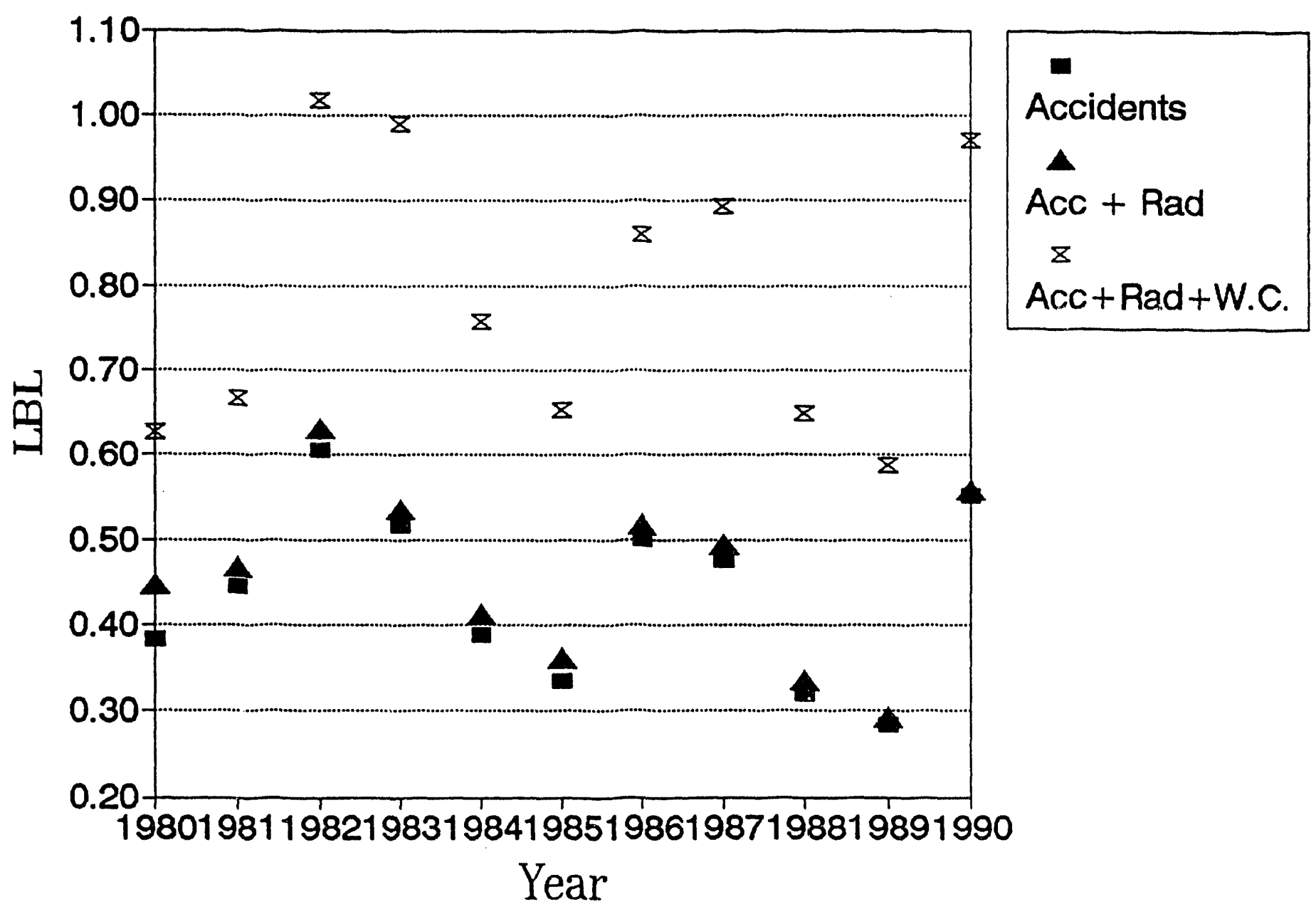

Figure C6.5. Percent of operating budget lost by year, including actual acrident losses, estimated radiological consequences, and reported worker's compensation expenditures. 


\section{C7. LLNL}

LLNL is a multipurpose national R\&D laboratory. Plant Engineering (crafts, gardeners, janitors, and other facility support) was separated out of the reporting statistics in 1986 . Those figures have been integrated back into the totals for this comparison. The Safety Department provides safety staff to programs on a matrix basis as the programs are willing to pay. These figures are included in this study. The high LWD value noted in 1985 in Fig. C7.1 is thought to be due to an excessive overtime effori to meet a major national milestone. A Tiger Team appraisal was conducted in February 1990. 
Table C7. LLNL site data.

\begin{tabular}{|c|c|c|c|c|c|c|c|c|c|c|}
\hline Year & TRC $r$ & LWD r & $\begin{array}{c}\text { Lab } \\
\text { Budget }\end{array}$ & $\begin{array}{l}\text { Safety } \\
\text { Budget }\end{array}$ & $\$ \%$ & $10 * \$ \%$ & $\begin{array}{l}\text { Lab } \\
\text { Staff }\end{array}$ & $\begin{array}{c}\text { Safety } \\
\text { Staff }\end{array}$ & FTE \% & $10^{\star}$ FTE \% \\
\hline 1980 & 3.0 & 14.2 & $\$ 462.10$ & $\$ 8.61$ & 1.86 & 18.63 & 7017 & 214.9 & 3.06 & 30.63 \\
\hline 1981 & 2.4 & 12.6 & $\$ 584.90$ & $\$ 9.10$ & 1.55 & 15.55 & 7236 & 205.4 & 2.84 & 28.39 \\
\hline 1982 & 2.1 & 13.2 & $\$ 618.50$ & $\$ 9.43$ & 1.52 & 15.24 & 7370 & 194.9 & 2.64 & 26.45 \\
\hline 1983 & 2.2 & 15.5 & $\$ 677.80$ & $\$ 11.30$ & 1.67 & 16.67 & 7450 & 198.6 & 2.67 & 26.66 \\
\hline 1984 & 2.0 & 18.7 & $\$ 808.50$ & $\$ 12.73$ & 1.57 & 15.75 & 7776 & 214.5 & 2.76 & 27.58 \\
\hline 1985 & 2.7 & 36.4 & $\$ 888.30$ & $\$ 14.59$ & 1.64 & 16.42 & 8063 & 237.9 & 2.95 & 29.51 \\
\hline 1986 & 1.4 & 15.64 & $\$ 932.10$ & $\$ 14.50$ & 1.56 & 15.55 & 8020 & 229.8 & 2.87 & 28.65 \\
\hline 1987 & 1.6 & 12.68 & $\$ 977.40$ & $\$ 14.67$ & 1.50 & 15.01 & 8280 & 225.4 & 2.72 & 27.22 \\
\hline 1988 & 1.6 & 15.15 & $\$ 999.20$ & $\$ 14.97$ & 1.50 & 14.98 & 8219 & 209.7 & 2.55 & 25.51 \\
\hline 1989 & 1.5 & 15.39 & $\$ 1,055.60$ & $\$ 16.01$ & 1.52 & 15.16 & 8247 & 213.8 & 2.59 & 25.92 \\
\hline 1990 & 2.3 & 22.42 & $\$ 1,070.50$ & $\$ 19.89$ & 1.86 & 18.58 & 8128 & 231.7 & 2.85 & 28.51 \\
\hline Avg $80-84$ & & & $M \$$ & $M \$$ & & & & & & \\
\hline Avg $85-89$ & $\begin{array}{l}2.34 \\
1.74\end{array}$ & 14.84 & $\$ 630.36$ & $\$ 10.23$ & 1.64 & 16.37 & 7370 & 205.66 & 2.79 & 27.94 \\
\hline Avg $80-89$ & $\begin{array}{l}1.74 \\
2.04\end{array}$ & 19.05 & $\$ 970.52$ & $\$ 14.94$ & 1.54 & 15.42 & 8166 & 223.32 & 2.74 & 27.36 \\
\hline & 2.04 & 16.95 & $\$ 800.44$ & $\$ 12.59$ & 1.59 & 15.90 & 7768 & 214.49 & 2.77 & 27.65 \\
\hline
\end{tabular}


Table C7. (Cont.)

\begin{tabular}{|c|c|c|c|c|c|c|c|c|c|c|}
\hline Year & TRCs & LWCs & LWDs & $\begin{array}{l}\text { Fatal } \\
\text { Cases }\end{array}$ & $\begin{array}{l}\text { FTEs lost } \\
\text { Accidently }\end{array}$ & $\begin{array}{r}\% \text { FTES } \\
\text { Lost }\end{array}$ & $\begin{array}{l}\text { Type } A+B \\
\text { Incidents }\end{array}$ & $\begin{array}{c}\text { Property } \\
\text { Loss } \$\end{array}$ & $\begin{array}{l}\text { \$s lost } \\
\text { Accidently }\end{array}$ & $\begin{array}{l}\% \text { Oper. } \\
\text { \$ Lost }\end{array}$ \\
\hline 1980 & 401 & 84 & 062 & 1 & 25 & 0010 & 1 & S3512150 & $\$ 50+5$ & 1 200 \\
\hline 1982 & 140 & 60 & 885 & 0 & 3.5 & 0.048 & 2 & $\$ 103,900$ & $\$ 1,409$ & 0.228 \\
\hline 1983 & 153 & 99 & 1066 & 0 & 4.3 & 0.057 & 0 & $\$ 83,991$ & $\$ 1,654$ & 0.244 \\
\hline 1986 & 110 & 88 & 1254 & 0 & 5.0 & 0.063 & 1 & $\$ 236,470$ & $\$ 1,896$ & 0.203 \\
\hline 1987 & 131 & 98 & 1050 & 0 & 4.2 & 0.051 & 1 & $\$ 5,000$ & $\$ 1,523$ & 0.156 \\
\hline 1988 & 129 & 97 & 1245 & 1 & 5.0 & 0.061 & 1 & $\$ 3,477,073$ & $\$ 6,184$ & 0.619 \\
\hline 1989 & 123 & 98 & 1269 & 0 & 5.1 & 0.062 & 0 & $\$ 5,000$ & $\$ 1,716$ & 0.163 \\
\hline 1990 & 189 & 131 & 1822 & 0 & 7.3 & 0.090 & 0 & $\$ 0$ & $\begin{array}{c}\$ 2,462 \\
\mathrm{~K} \$\end{array}$ & 0.230 \\
\hline
\end{tabular}


Table C7. (Cont.)

\begin{tabular}{|c|c|c|c|c|c|c|c|c|}
\hline & $\begin{array}{l}\text { LLNL } \\
\text { Year }\end{array}$ & $\begin{array}{c}\text { Person } \\
\text { Rem }\end{array}$ & $\begin{array}{l}\$ 1000 \text { per } \\
\text { ManRem }\end{array}$ & $\begin{array}{c}\text { Acc. + Rad. } \\
\$ \text { lost }\end{array}$ & $\begin{array}{c}\text { Acc. + Rad. } \\
\% \text { Lost }\end{array}$ & $\begin{array}{l}\text { Worker's } \\
\text { Comp Costs }\end{array}$ & $\begin{array}{l}\text { Total } \\
\% \text { Lost }\end{array}$ & $\begin{array}{c}\text { Worker's Comp } \\
\% \text { of Oper. } \$\end{array}$ \\
\hline & & & & & & & & \\
\hline & 1980 & 77 & $\$ 77$ & $\$ 5,992$ & 1.30 & $\$ 314$ & 1.36 & 0.068 \\
\hline & 1981 & 78 & $\$ 78$ & $\$ 3,391$ & 0.58 & $\$ 424$ & 0.65 & 0.072 \\
\hline & 1982 & 102 & $\$ 102$ & $\$ 1,511$ & 0.24 & $\$ 654$ & 0.35 & 0.106 \\
\hline & 1983 & 80 & $\$ 80$ & $\$ 1,734$ & 0.26 & $\$ 1,991$ & 0.55 & 0.294 \\
\hline & 1984 & 82 & $\$ 82$ & $\$ 2,135$ & 0.26 & $\$ 832$ & 0.37 & 0.103 \\
\hline & 1985 & 63 & $\$ 63$ & $\$ 4,072$ & 0.46 & $\$ 1,562$ & 0.63 & 0.176 \\
\hline & 1986 & 62 & $\$ 62$ & $\$ 1,958$ & 0.21 & $\$ 1,836$ & 0.41 & 0.197 \\
\hline & 1987 & 28 & $\$ 28$ & $\$ 1,551$ & 0.16 & $\$ 1,282$ & 0.29 & 0.131 \\
\hline & 1938 & 28 & $\$ 28$ & $\$ 6,212$ & 0.62 & $\$ 1,945$ & 0.82 & 0.195 \\
\hline & 1989 & 34 & $\$ 34$ & $\$ 1,750$ & 0.17 & $\$ 1,845$ & 0.34 & 0.175 \\
\hline is & 1990 & 28 & $\$ 28$ & $\$ 2,490$ & 0.23 & $\$ 1,734$ & 0.39 & 0.162 \\
\hline & & & $K \$$ & $\mathrm{~K} \$$ & & $\mathrm{~K} \$$ & & \\
\hline & Avg $80-84$ & 84 & $\$ 84$ & $\$ 2,953$ & 0.47 & $\$ 843$ & 0.60 & 0.134 \\
\hline & Avg $85-89$ & 43 & $\$ 43$ & $\$ 3,109$ & 0.32 & $\$ 1,694$ & 0.49 & 0.175 \\
\hline & Avg $80-89$ & 63 & $\$ 63$ & $\$ 3,031$ & 0.38 & $\$ 1,269$ & 0.54 & 0.158 \\
\hline
\end{tabular}




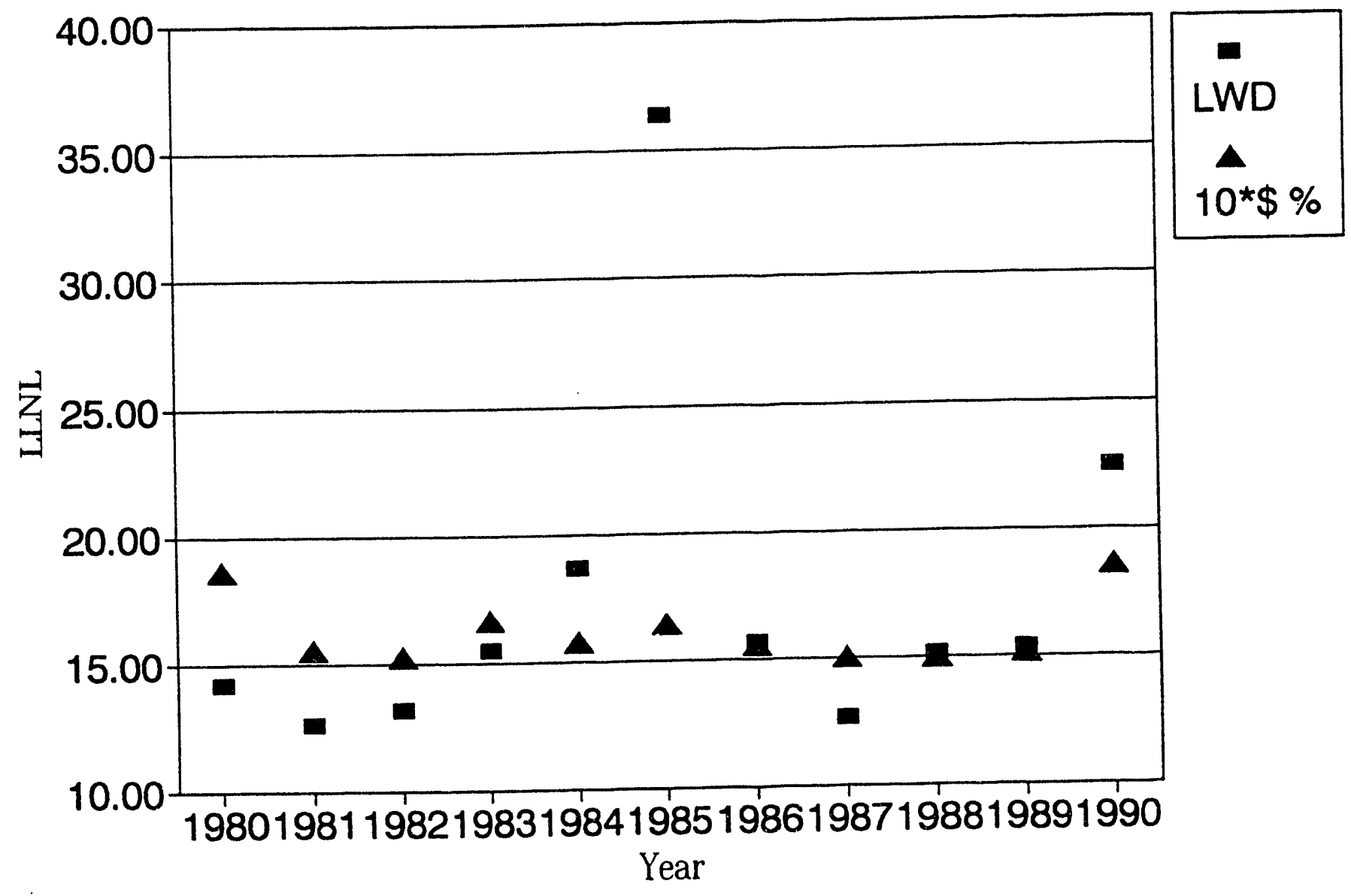

Figure C7.1. Lost workdays per 200k man-hr, 10 times safety budget percentage. 


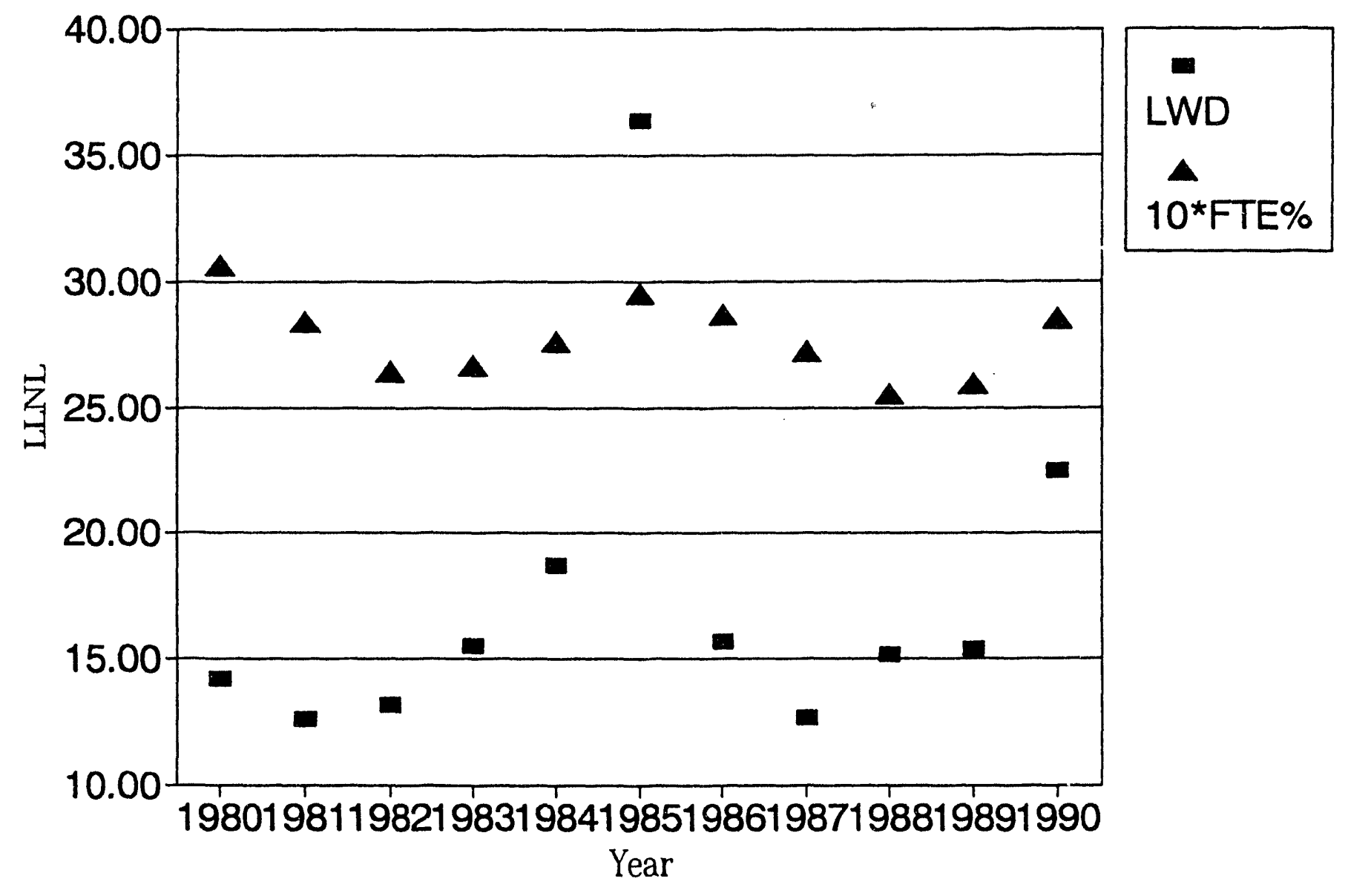

Figure C7.2. Lost workdays per 200k man-hr, 10 times safety manpower percentage. 


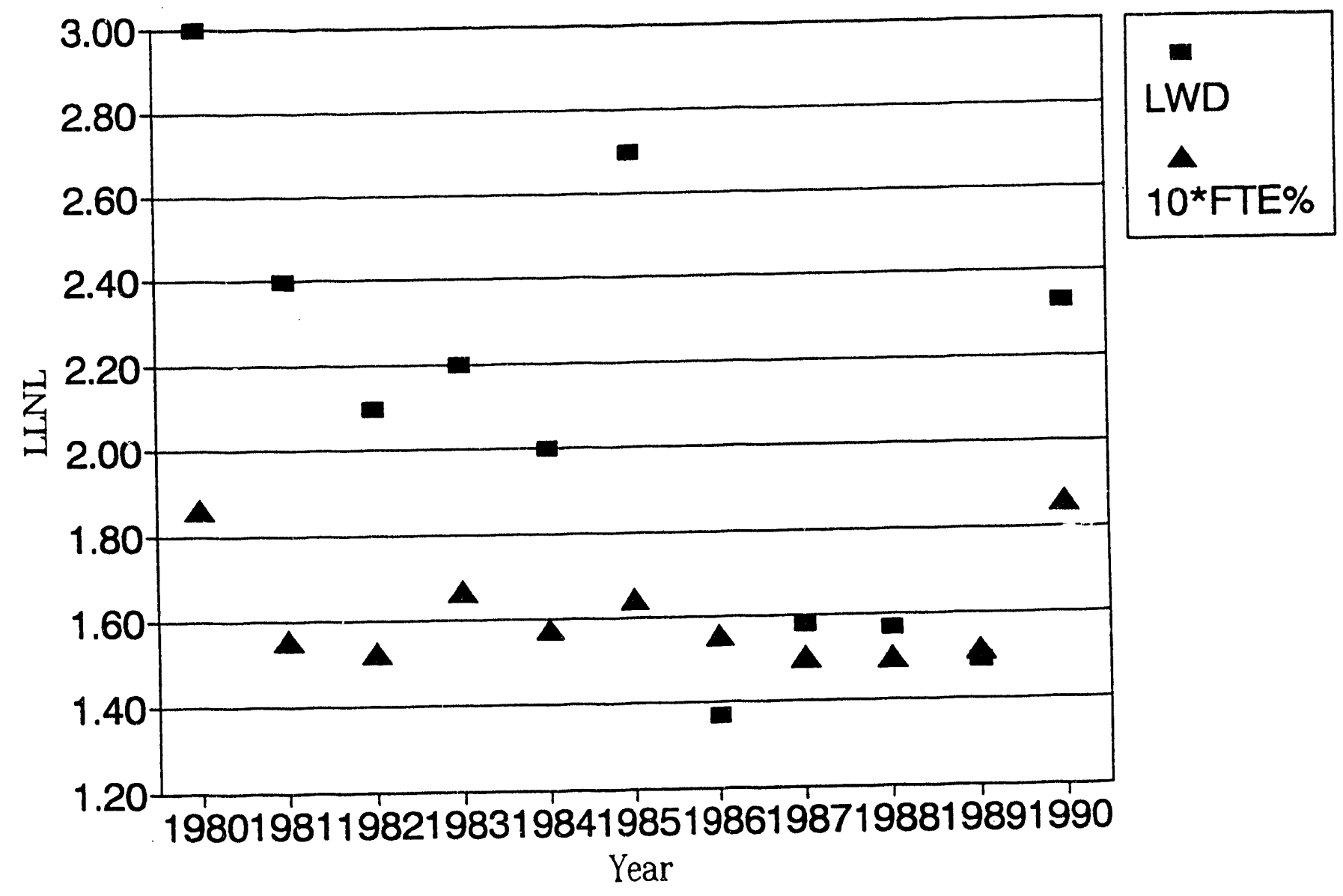

Figure C7.3. Total reportable case rate, percent of Laboratory budget spent on safety. 


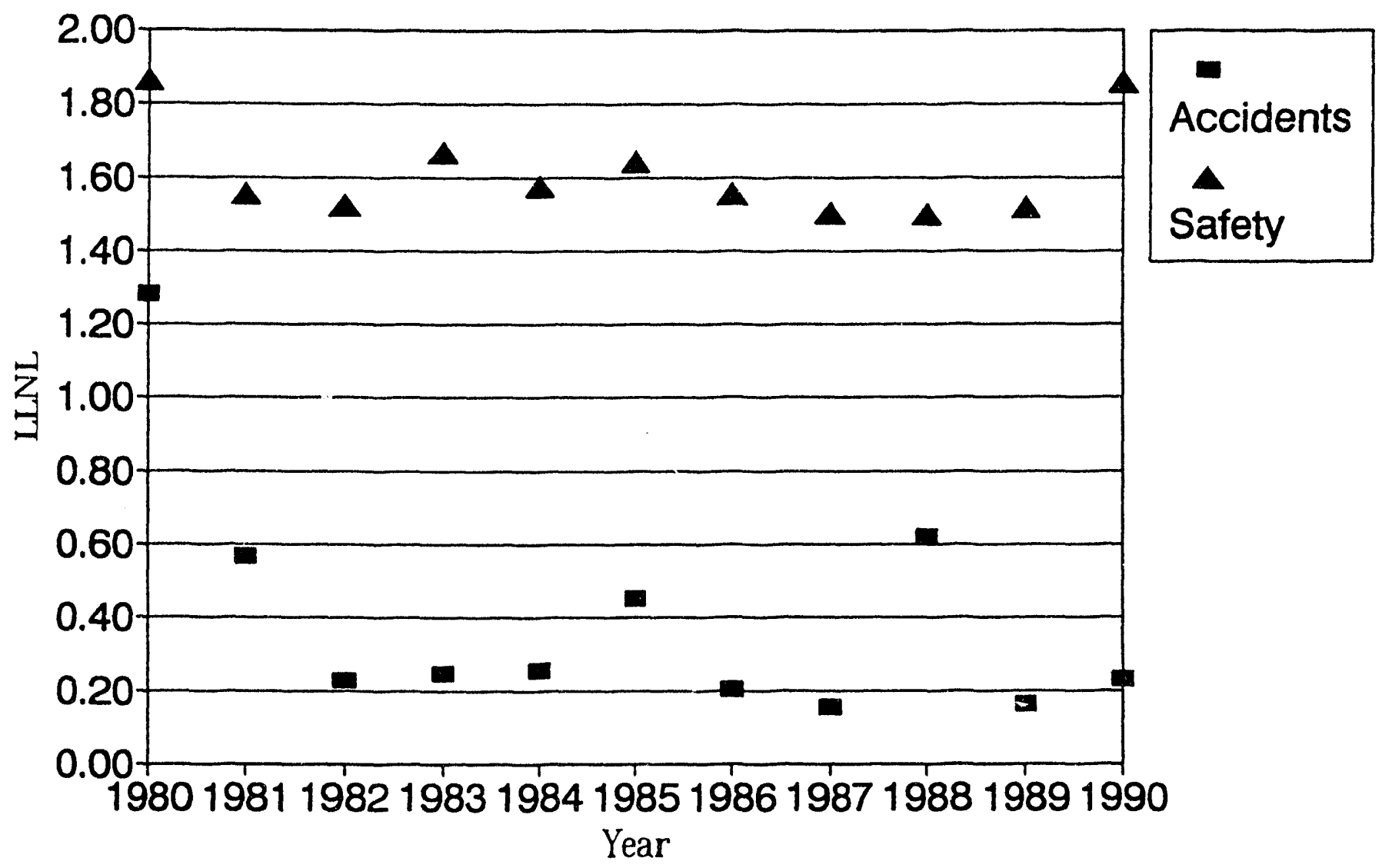

Figure C7.4. Percent of budget lost accidentally, percent of Laboratory budget spent on safety. 


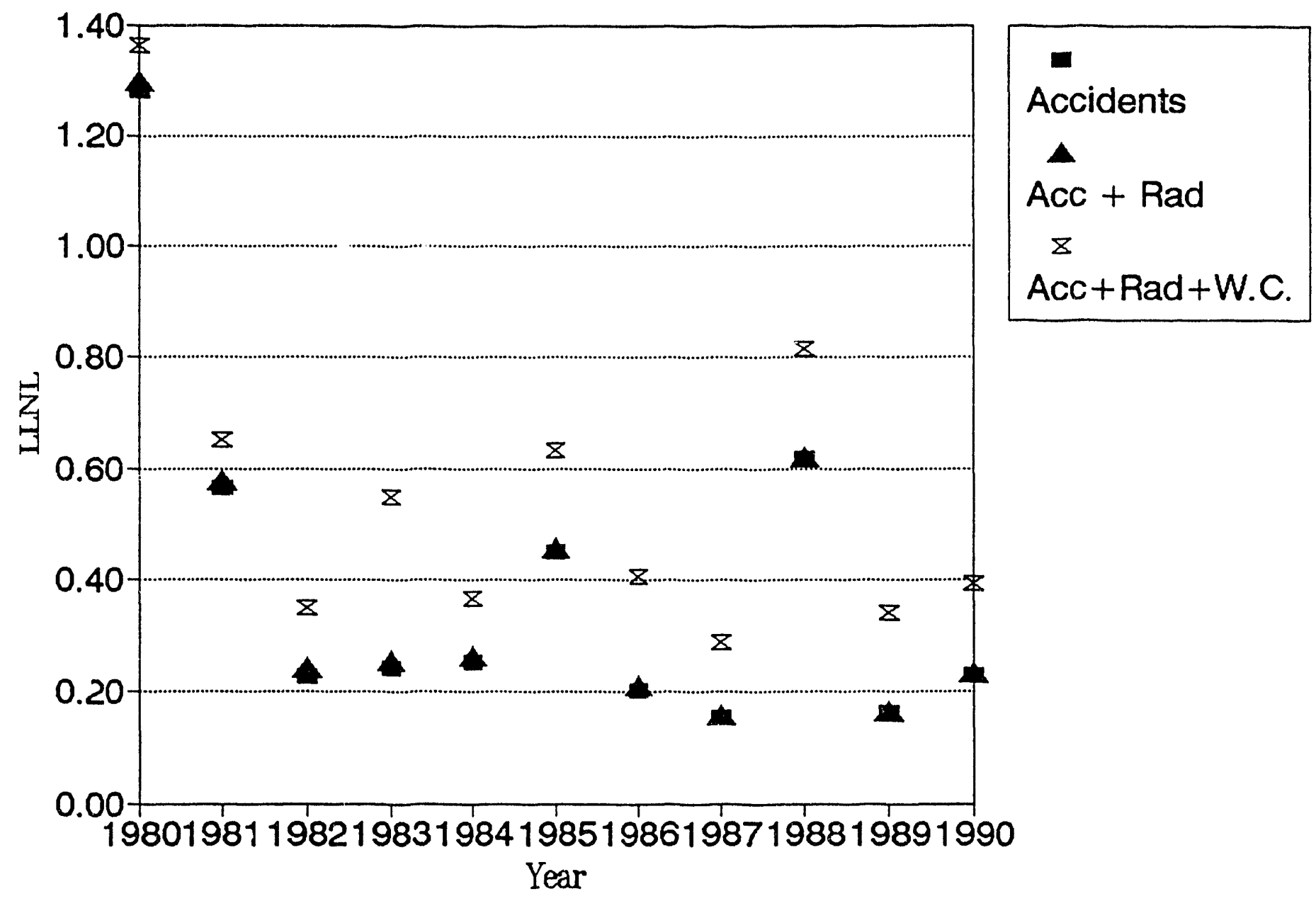

Figure C7.5. Percent of operating budget lost by year, including actual accident losses, estimated radiological consequences, and reported worker's compensation expenditures. 


\section{C8. Mound}

Mound is primarily a production facility with some $R \& D$. It separated security performance figures out of the general site statistics in 1987. There was a change of contractor, from Monsanto to EG\&G, in 1988. A Tiger Team appraisal was conducted in October 1989. The insurance carrier was unwilling to provide worker's compensation expenditure data. 
Table C8. Mound site data.

\begin{tabular}{|c|c|c|c|c|c|c|c|c|c|c|}
\hline Year & TRC r & LWD r & $\begin{array}{c}\text { Plant } \\
\text { Budget }\end{array}$ & $\begin{array}{l}\text { Safety } \\
\text { Budget }\end{array}$ & $\$ \%$ & $10 * \$ \%$ & $\begin{array}{l}\text { Lab } \\
\text { Staff }\end{array}$ & $\begin{array}{c}\text { Safety } \\
\text { Staff }\end{array}$ & FTE \% & $10^{\star}$ FTE\% \\
\hline & & & & & & & & & & \\
\hline 1980 & 0.3 & 0.0 & $\$ 75.6$ & $\$ 2.24$ & 2.96 & 29.58 & 1840 & 62 & 3.37 & 33.70 \\
\hline 1981 & 0.8 & 5.2 & $\$ 90.2$ & $\$ 2.52$ & 2.79 & 27.89 & 1952 & 58 & 2.97 & 29.71 \\
\hline 1982 & 0.6 & 2.5 & $\$ 118.3$ & $\$ 2.58$ & 2.18 & 21.81 & 2104 & 54 & 2.57 & 25.67 \\
\hline 1983 & 0.7 & 3.4 & $\$ 130.5$ & $\$ 2.66$ & 2.04 & 20.36 & 2207 & 55 & 2.49 & 24.92 \\
\hline 1984 & 0.7 & 7.8 & $\$ 162.0$ & $\$ 4.24$ & 2.62 & 26.17 & 2348 & 70 & 2.98 & 29.81 \\
\hline 1985 & 0.8 & 2.7 & $\$ 172.2$ & $\$ 3.84$ & 2.23 & 22.32 & 2423 & 65 & 2.68 & 26.83 \\
\hline 1986 & 0.4 & 3.0 & $\$ 177.7$ & $\$ 3.27$ & 1.84 & 18.39 & 2357 & 61 & 2.59 & 25.88 \\
\hline 1987 & 0.6 & 4.7 & $\$ 175.1$ & $\$ 5.18$ & 2.96 & 29.58 & 2281 & 128 & 5.61 & 56.12 \\
\hline 1988 & 0.5 & 6.9 & $\$ 177.4$ & $\$ 7.51$ & 4.23 & 42.34 & 2212 & 134 & 6.06 & 60.58 \\
\hline 1989 & 0.8 & 12.3 & $\$ 171.8$ & $\$ 5.23$ & 3.04 & 30.44 & 2161 & 107 & 4.95 & 49.51 \\
\hline 1990 & 0.7 & 6.8 & $\begin{array}{c}\$ 170.3 \\
M \$\end{array}$ & $\begin{array}{c}\$ 7.69 \\
M \$\end{array}$ & 4.52 & 45.15 & 2205 & 116 & 5.26 & 52.61 \\
\hline Avg $80-84$ & 0.62 & 3.78 & $\$ 115.3$ & $\$ 2.85$ & 2.52 & 25.16 & 2090.2 & 59.8 & 2.88 & 28.76 \\
\hline Avg $85-89$ & 0.62 & 5.92 & $\$ 174.8$ & $\$ 5.01$ & 2.86 & 28.61 & 2286.8 & 99.0 & 4.38 & 43.78 \\
\hline Avg $80-89$ & 0.62 & 4.85 & $\$ 145.1$ & $\$ 3.93$ & 2.69 & 26.89 & 2188.5 & 79.4 & 3.63 & 36.27 \\
\hline
\end{tabular}


Table C8. (Cont.)

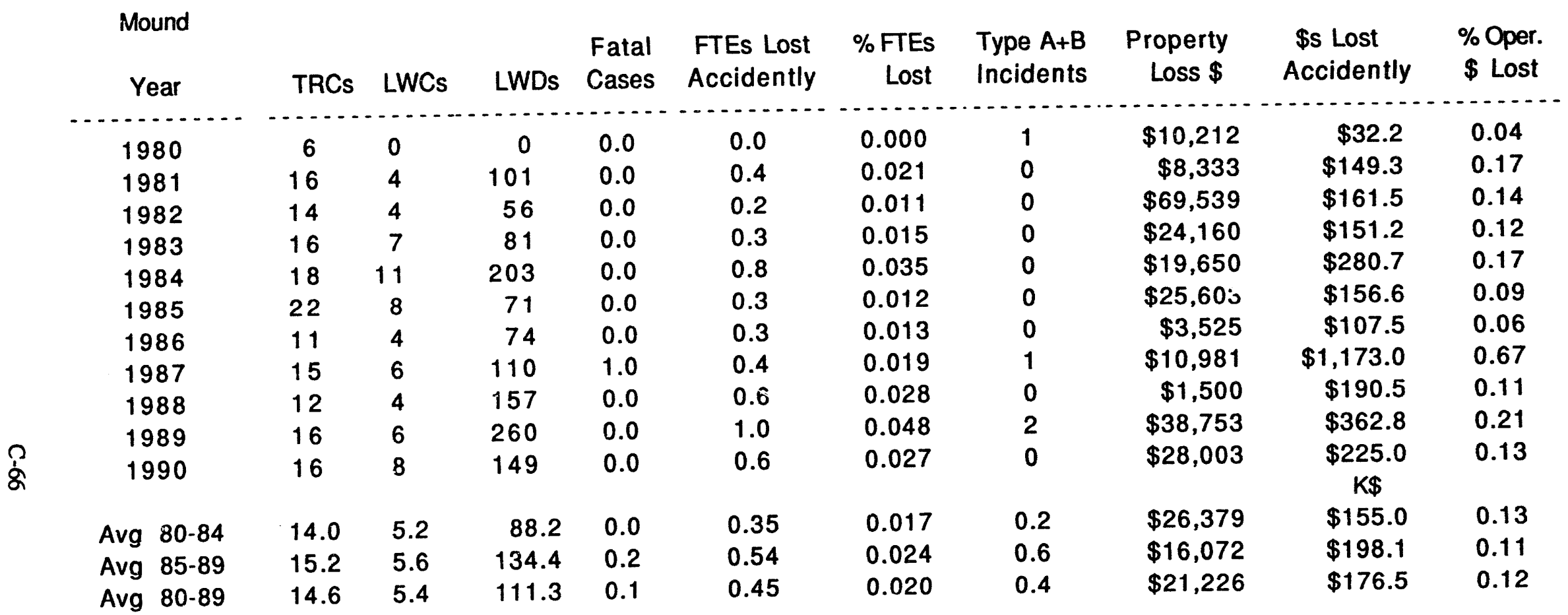


Table C8. (Cont.)

\begin{tabular}{crrrrr} 
Mound & $\begin{array}{c}\text { Person } \\
\text { Rem }\end{array}$ & $\begin{array}{c}\$ 1000 \text { per } \\
\text { ManRem }\end{array}$ & $\begin{array}{c}\text { Acc. + Rad. } \\
\$ \text { Lost }\end{array}$ & $\begin{array}{c}\text { Acc. + Rad. } \\
\% \text { Lost }\end{array}$ & $\begin{array}{c}\text { Worker's } \\
\text { Comp Costs }\end{array}$ \\
\hline 1980 & 71 & $\$ 71$ & $\$ 103$ & 0.14 & $\mathrm{n} / \mathrm{a}$ \\
1981 & 97 & $\$ 97$ & $\$ 246$ & 0.27 & $\mathrm{n} / \mathrm{a}$ \\
1982 & 100 & $\$ 100$ & $\$ 262$ & 0.22 & $\mathrm{n} / \mathrm{a}$ \\
1983 & 115 & $\$ 115$ & $\$ 266$ & 0.20 & $\mathrm{n} / \mathrm{a}$ \\
1984 & 144 & $\$ 144$ & $\$ 425$ & 0.26 & $\mathrm{n} / \mathrm{a}$ \\
1985 & 211 & $\$ 211$ & $\$ 368$ & 0.21 & $\mathrm{n} / \mathrm{a}$ \\
1986 & 151 & $\$ 151$ & $\$ 259$ & 0.15 & $\mathrm{n} / \mathrm{a}$ \\
1987 & 59 & $\$ 59$ & $\$ 1,232$ & 0.70 & $\mathrm{n} / \mathrm{a}$ \\
1988 & 65 & $\$ 65$ & $\$ 256$ & 0.14 & $\mathrm{n} / \mathrm{a}$ \\
1989 & 21 & $\$ 21$ & $\$ 384$ & 0.22 & $\mathrm{n} / \mathrm{a}$ \\
1990 & 4 & $\$ 4$ & $\$ 229$ & 0.13 & $\mathrm{n} / \mathrm{a}$ \\
Avg $80-84$ & 105 & $\$ 105$ & $\$ 260$ & 0.22 & \\
Avg $85-89$ & 101 & $\$ 101$ & $\$ 499$ & 0.29 & \\
Avg $80-89$ & 103 & $\$ 103$ & $\$ 380$ & 0.25 &
\end{tabular}




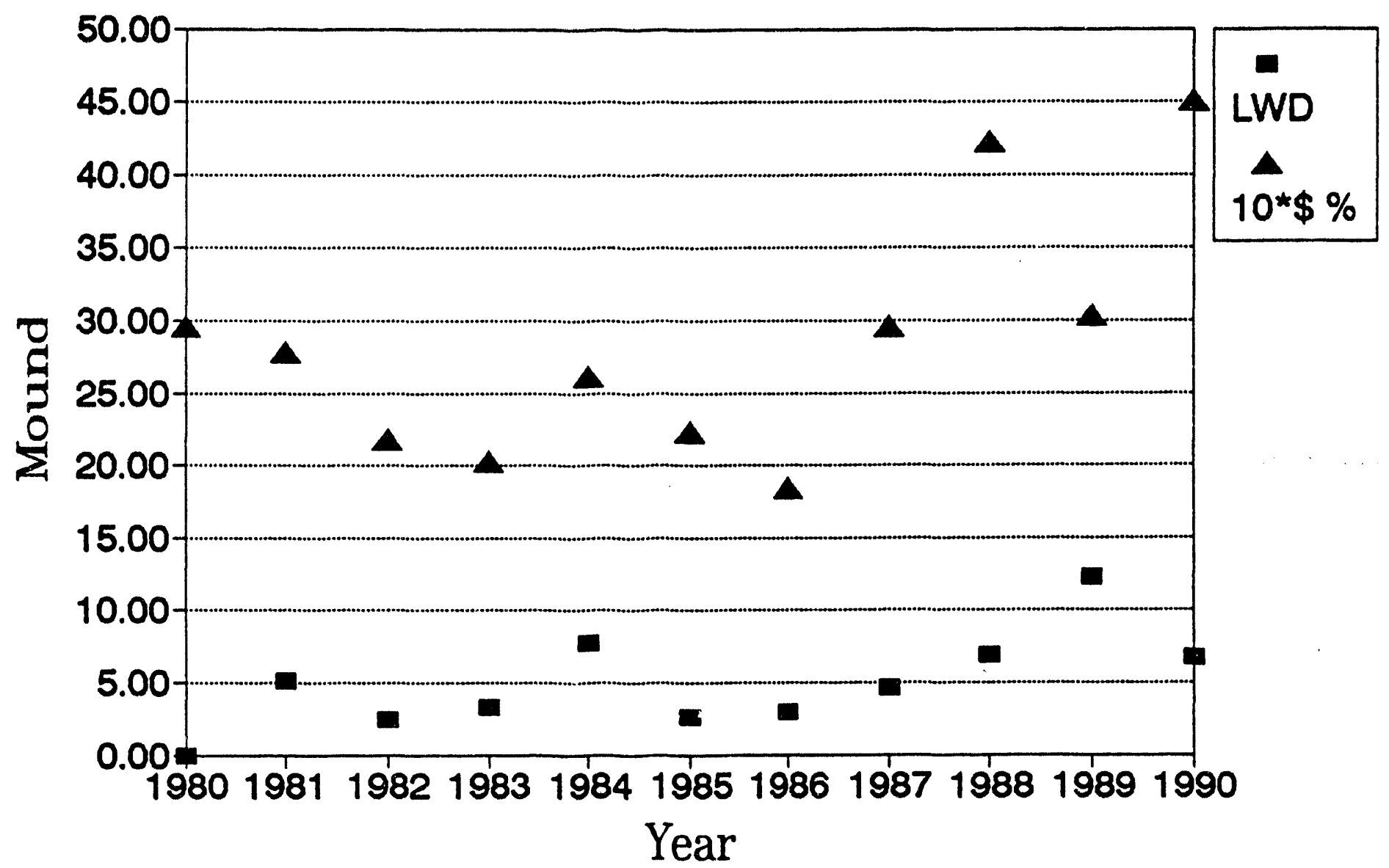

Figure C8.1. Lost workdays per 200k man-hr, 10 times safety budget percentage. 


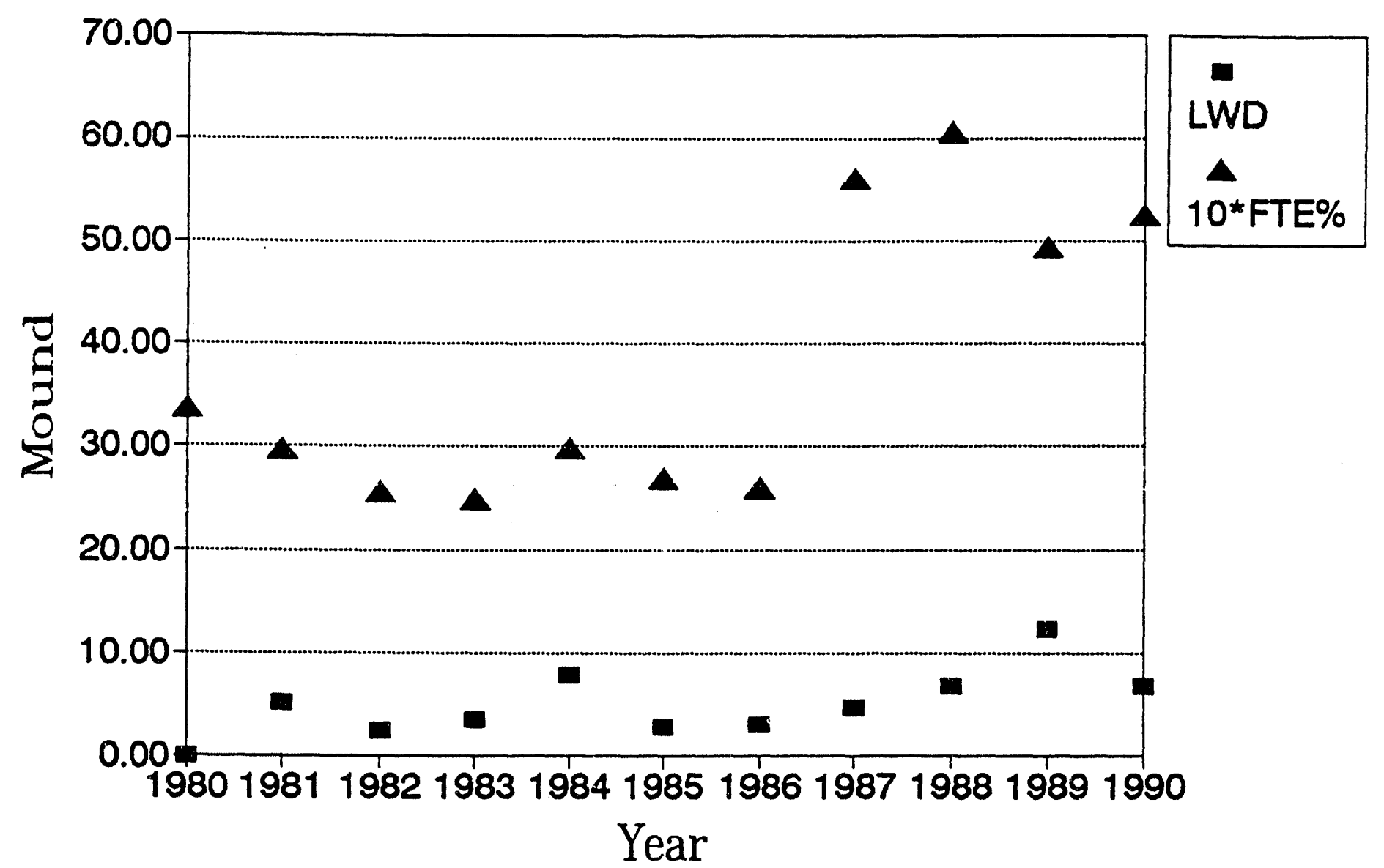

Figure C8.2. Lost workdays per $200 \mathrm{k}$ man-hr, 10 times safety manpower percentage. 


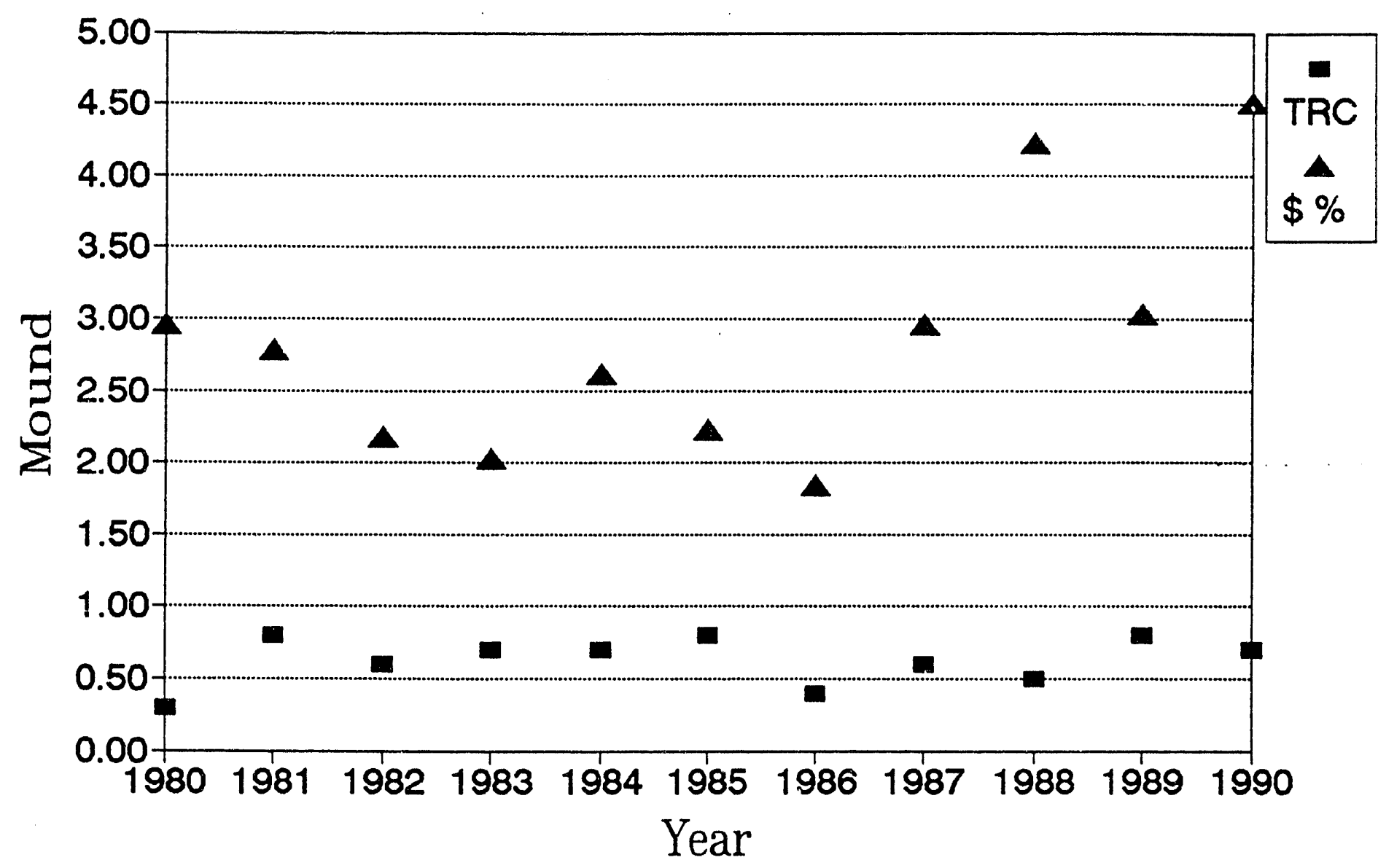

Figure C8.3. Total reportable case rate, percent of Laboratory budget spent on safety. 


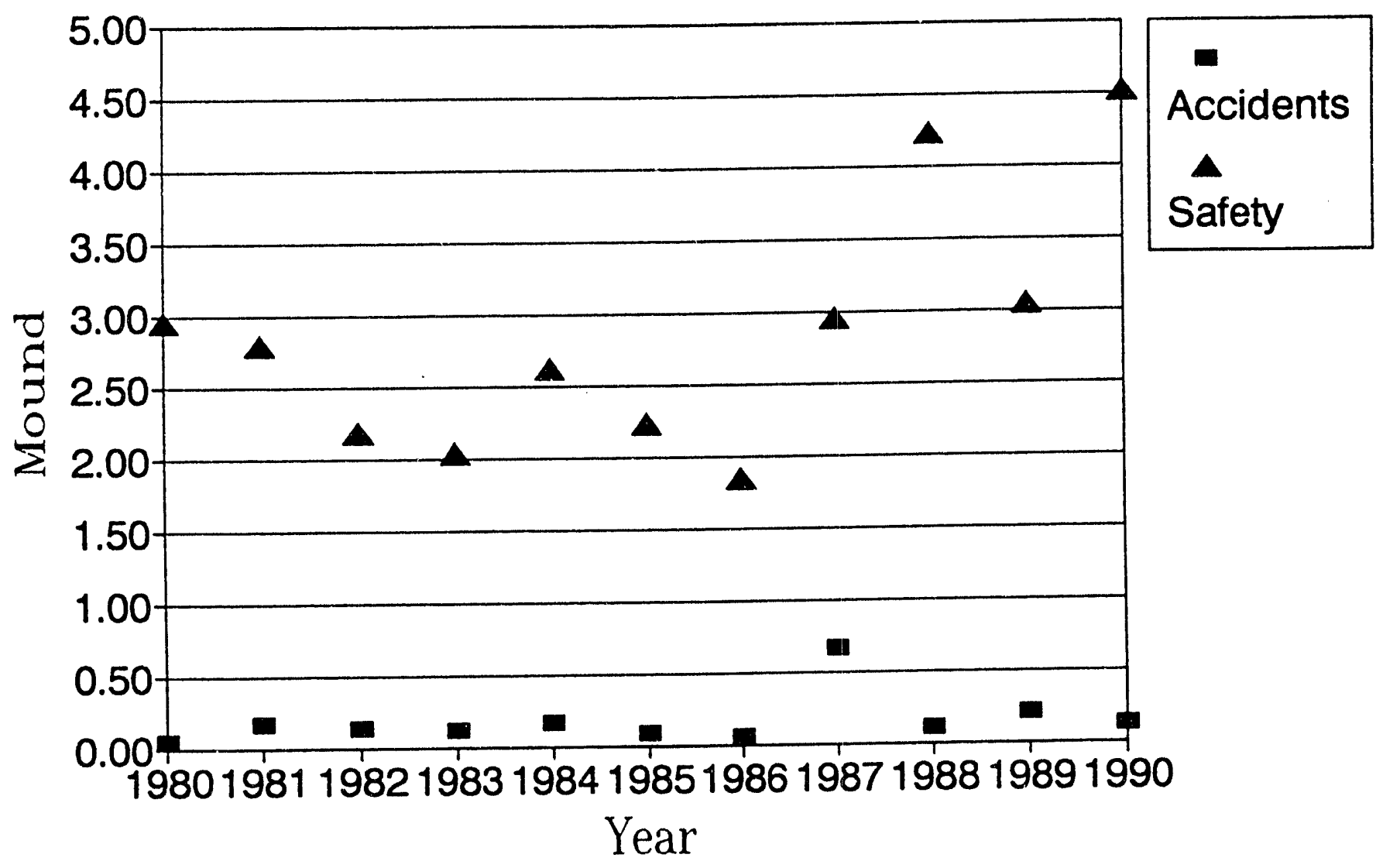

Figure C8.4. Percent of budget lost accidentally, percent of Laboratory budget spent on safety. 


\section{C9. ORNL}

ORNL ia a multiprogram national R\&D laboratory. There was a change of contractor, from Union Carbide to Martin Marietta, in 1984. The safety performance values used here are those supplied by EG\&G Management Information System reports. A Tiger Team appraisal was conducted in November 1990. 
Table C9. ORNL site data.

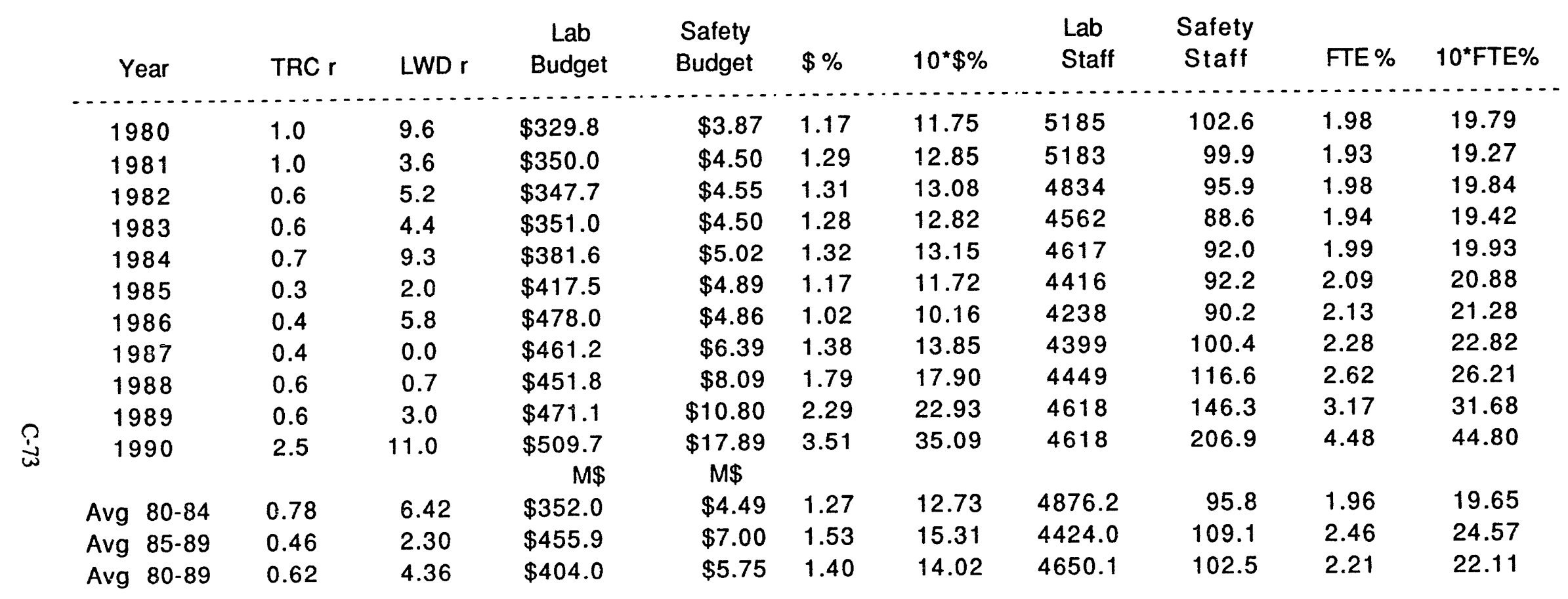


Table C9. (Cont.)

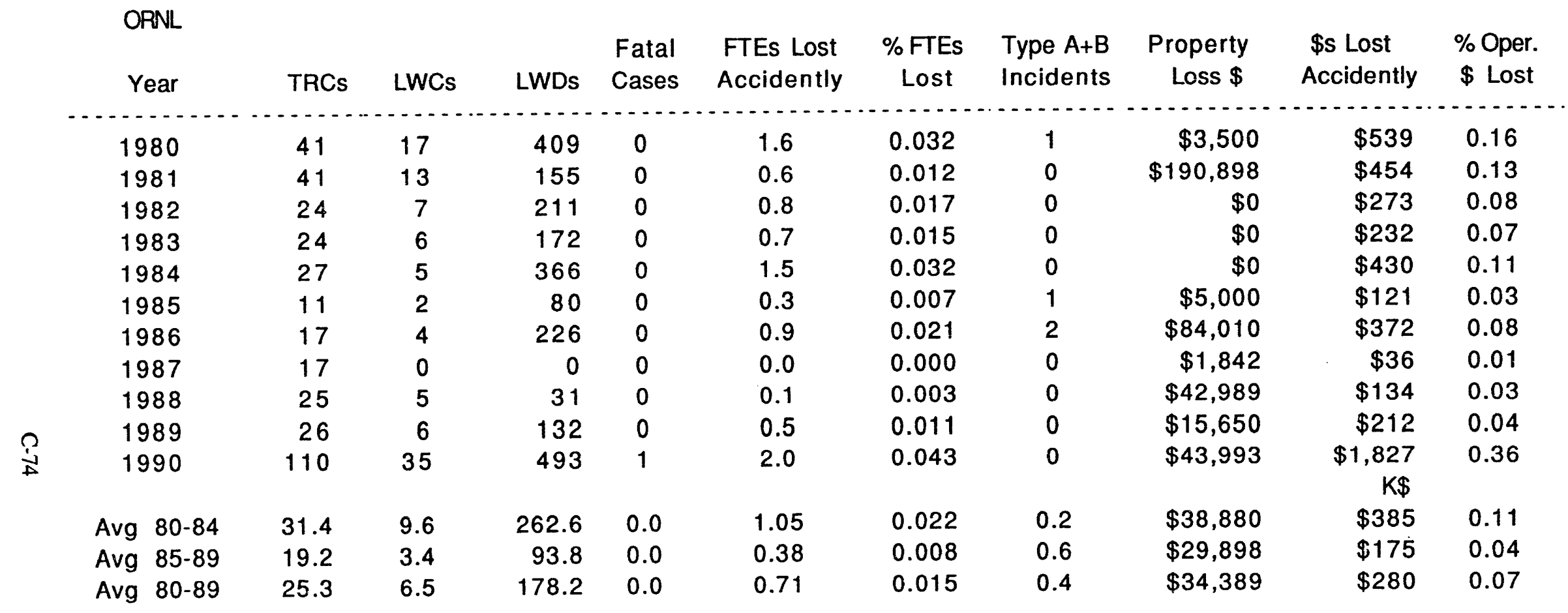


Table C9. (Cont.)

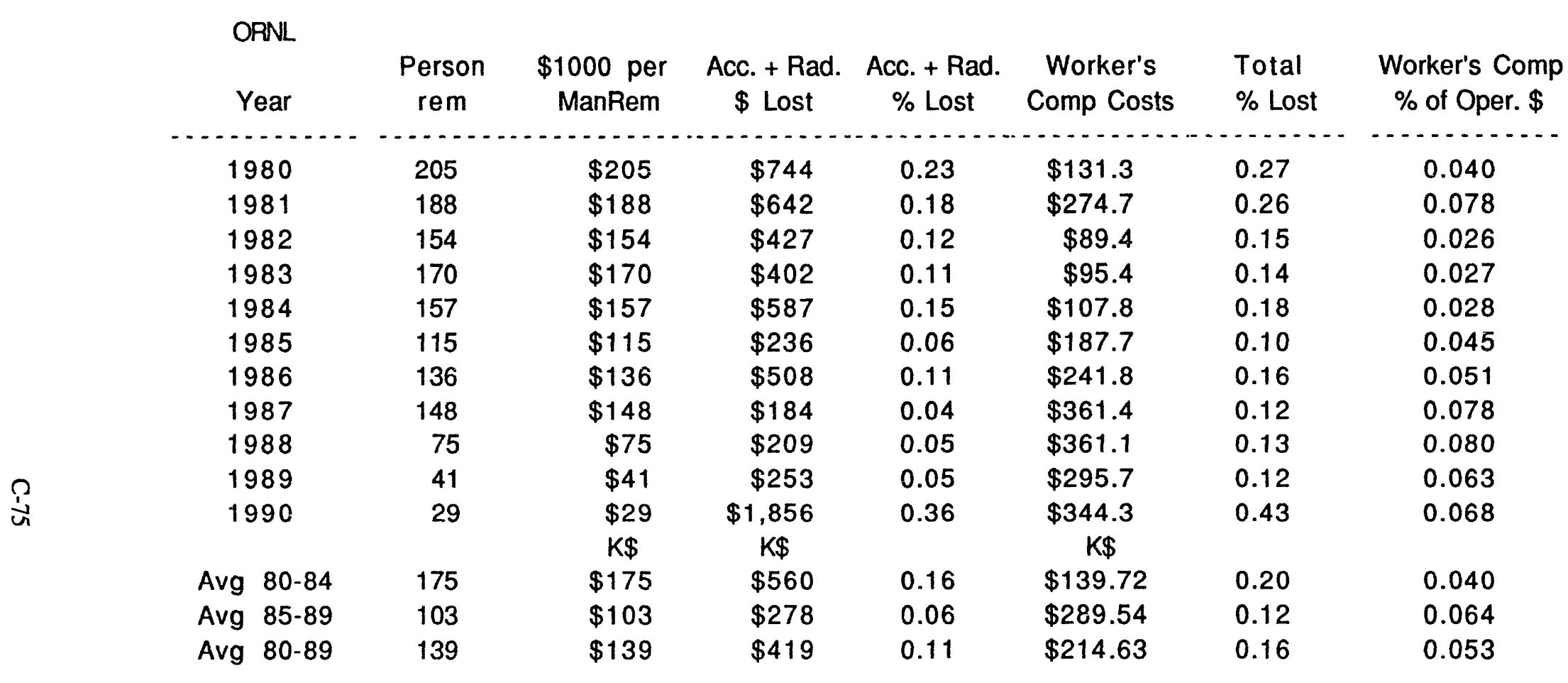




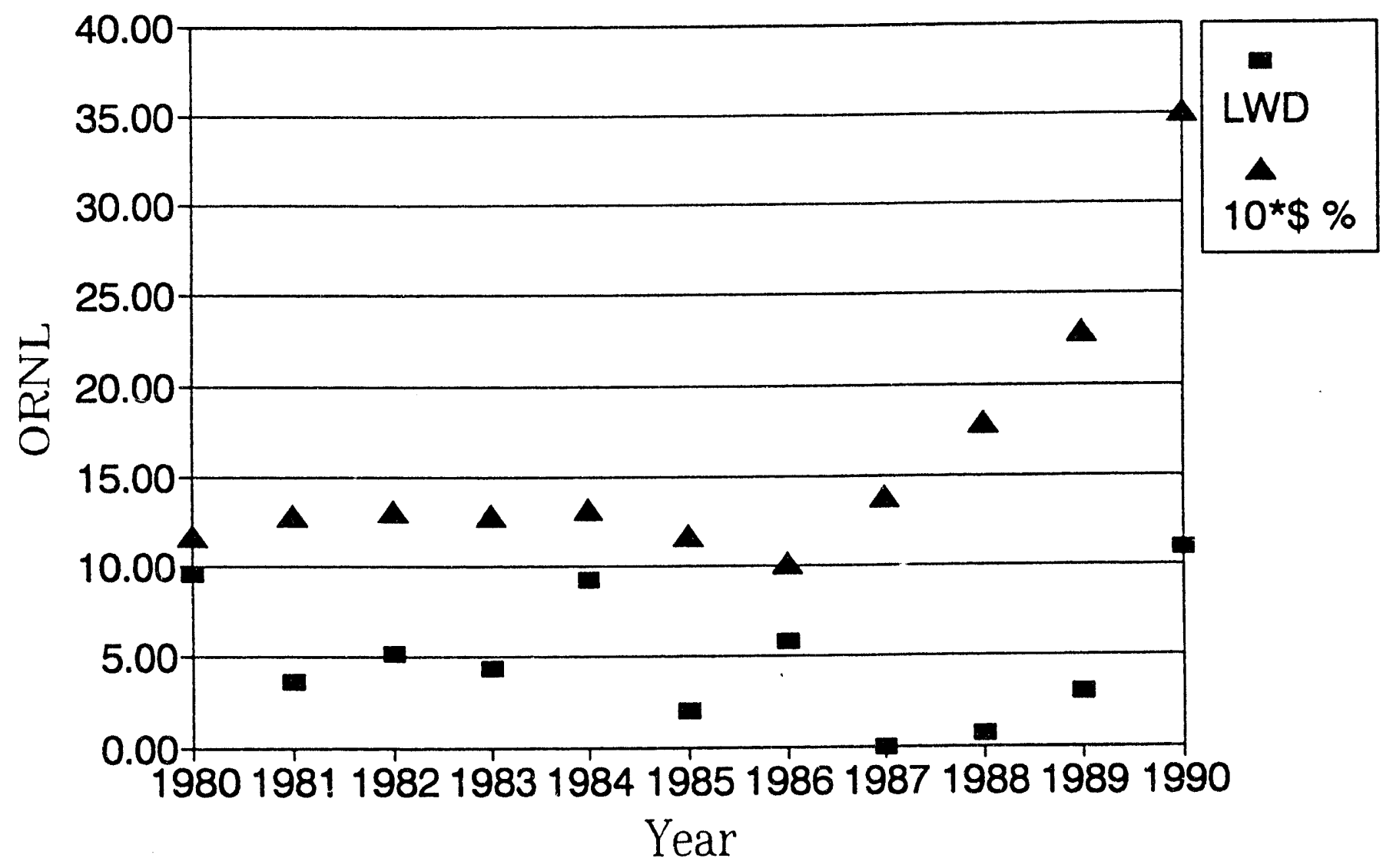

Figure C9.1. Lost workdays per 200k man-hr, 10 times safety budget percentage. 


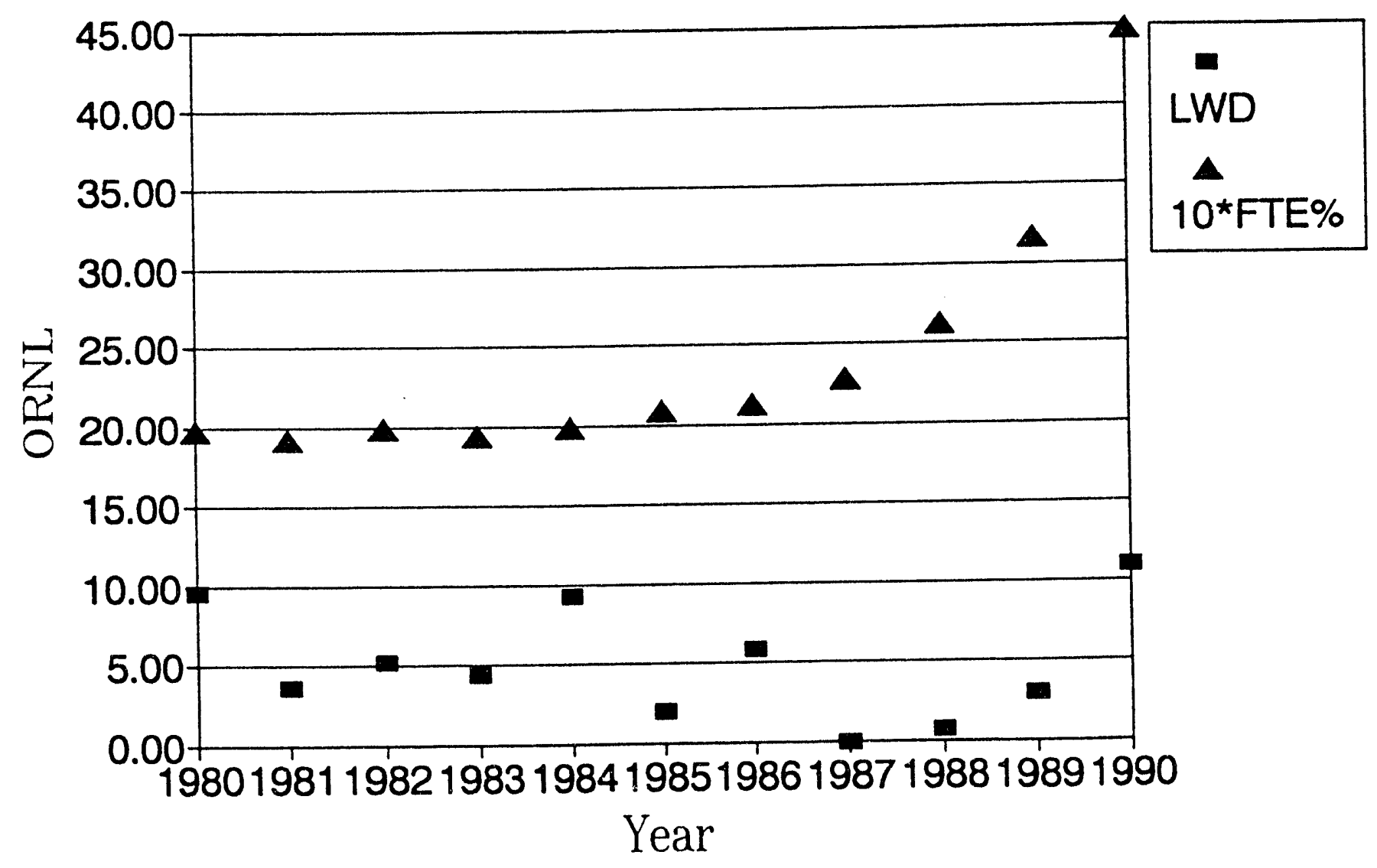

Figure C9.2. Lost workdays per $200 \mathrm{k}$ man-hr, 10 times safety manpower percentage. 


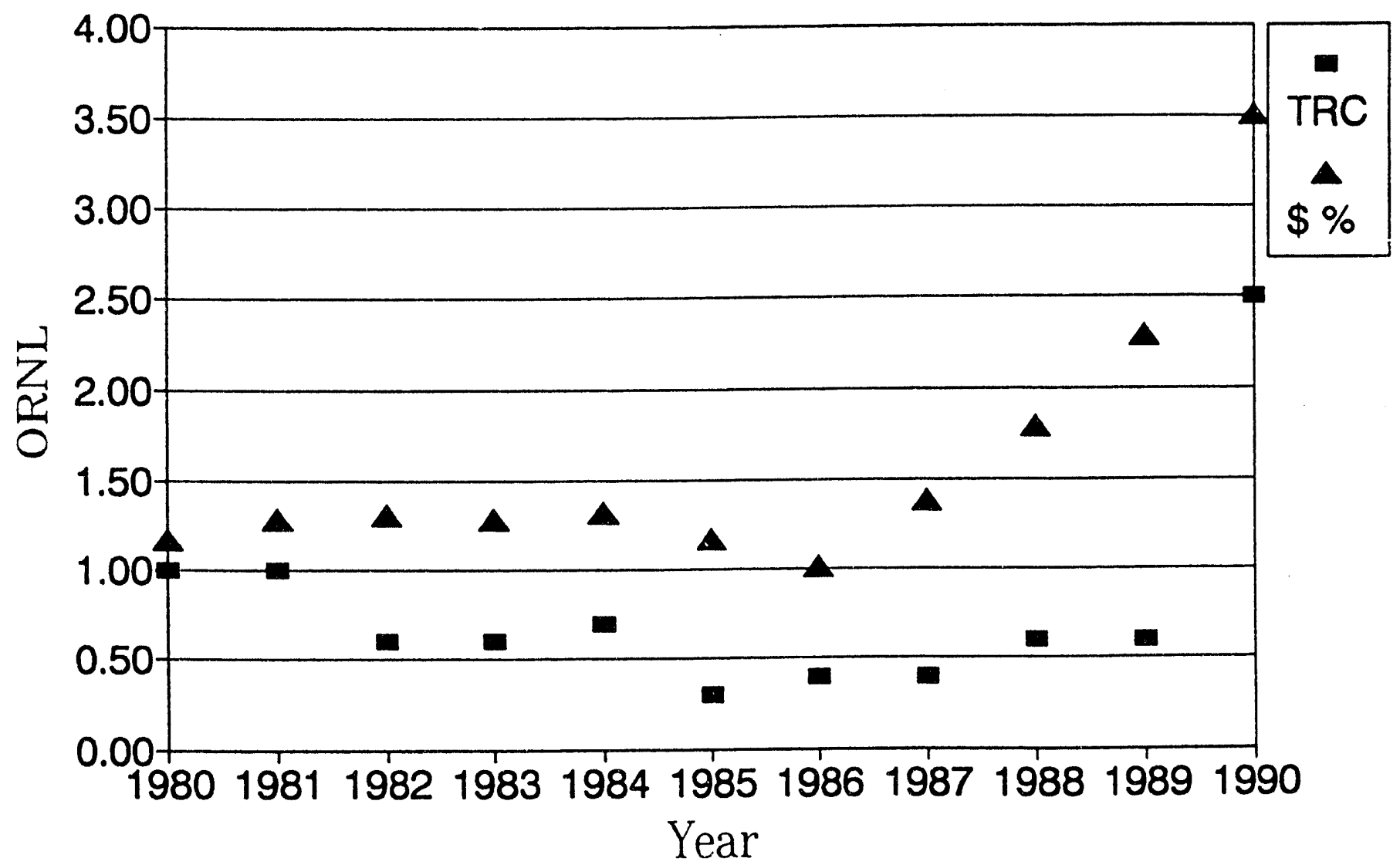

Figure C9.3. Total reportable case rate, percent of Laboratory budget spent on safety. 


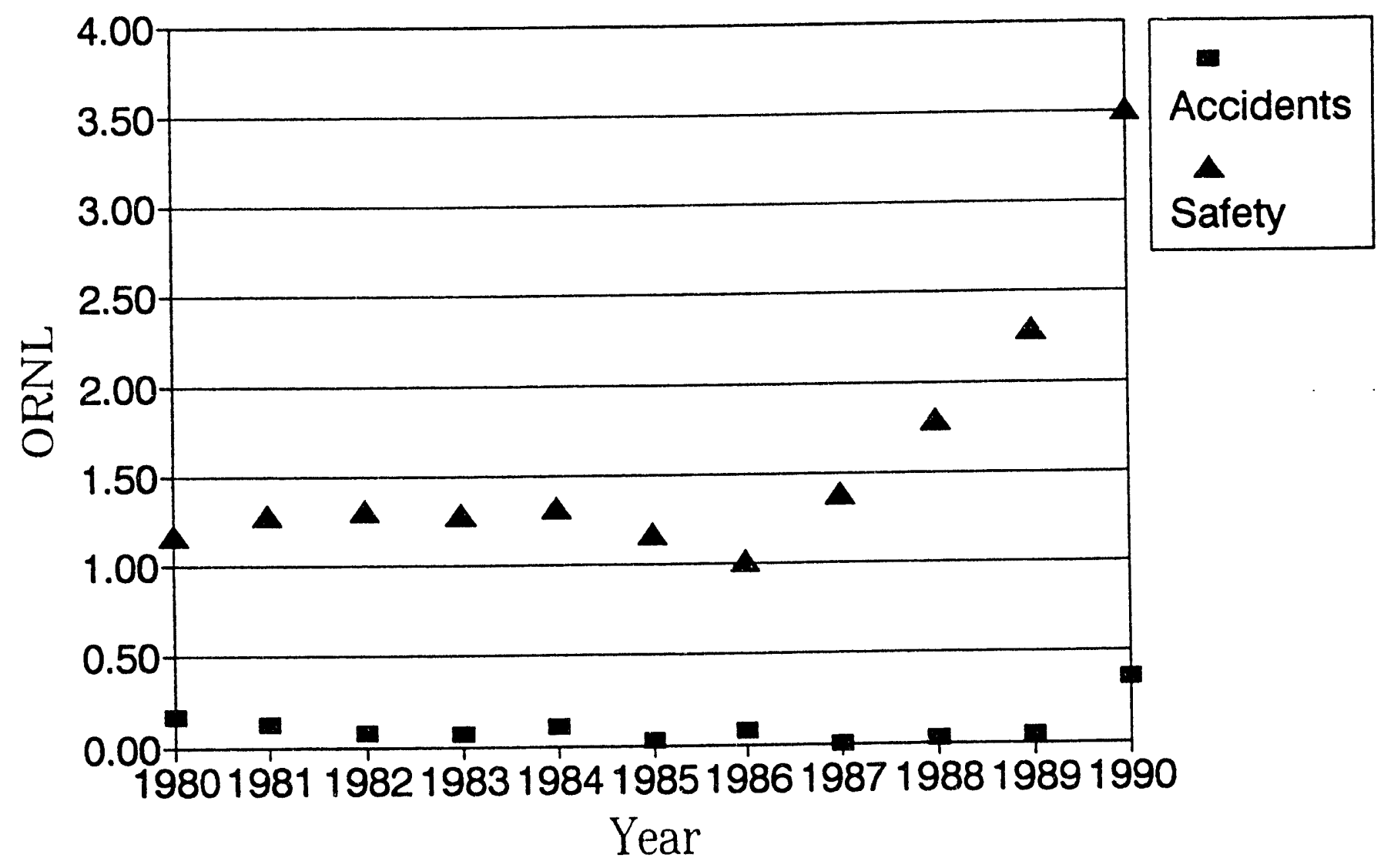

Figure C9.4. Percent of budget lost accidentally, percent of Laboratory budget spent on safety. 


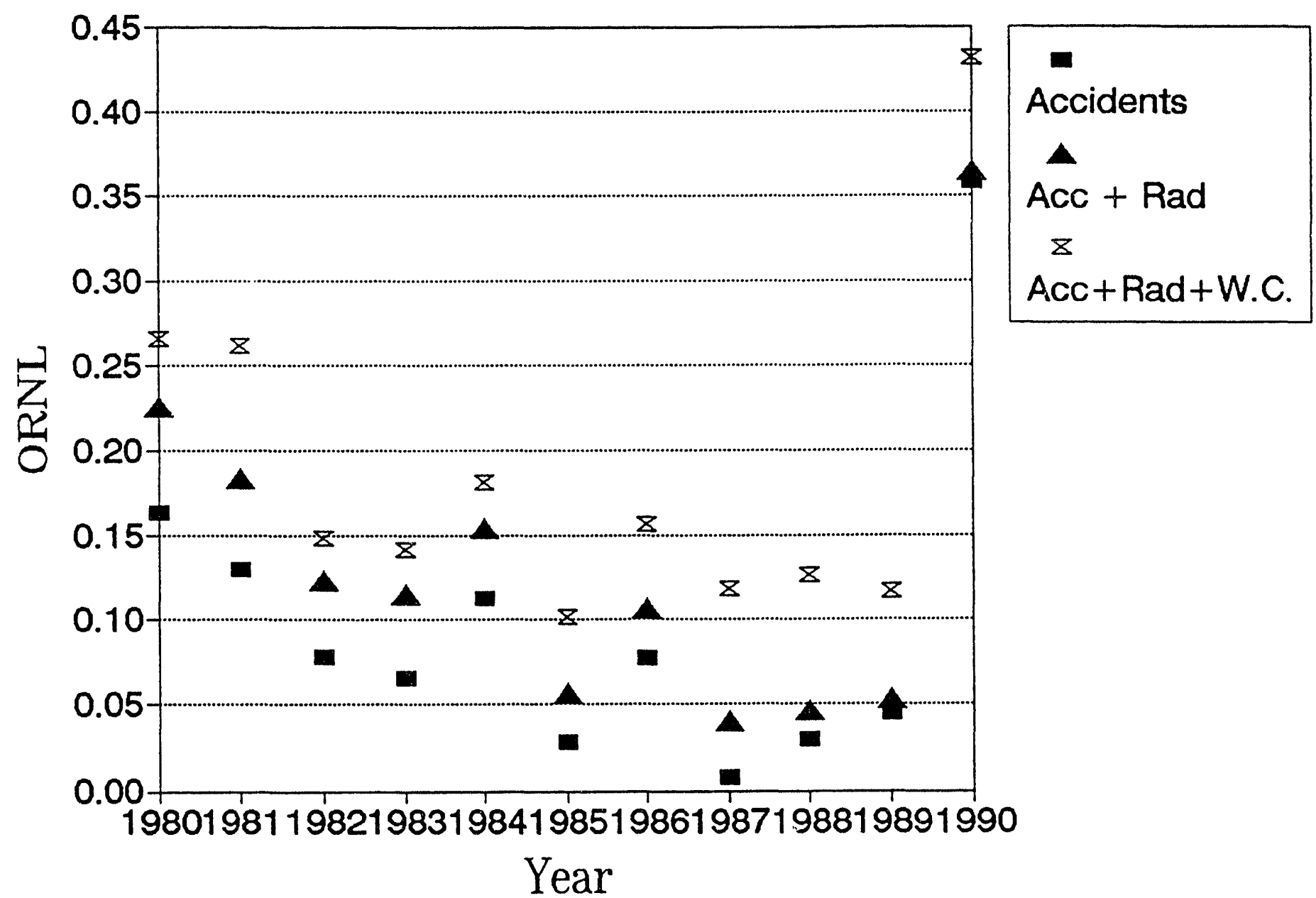

Figure C9.5. Percent of operating budget lost by year, including actual accident losses, estimated radiological consequences, and reported worker's compensation expenditures. 


\section{C10. Pantex}

Pantex is primarily a production facility. The site indicates that it has made no change in its OSHA reporting practices, but it believes that the change in occurrence rate is due largely to the effects of a layoff and contract negations on morale. A Tiger Team appraisal was conducted in October 1989. The contractor changed insurance carriers in 1981 and was unable to obtain worker's compensation data prior to that date. 
Table C10. Pantex site data.

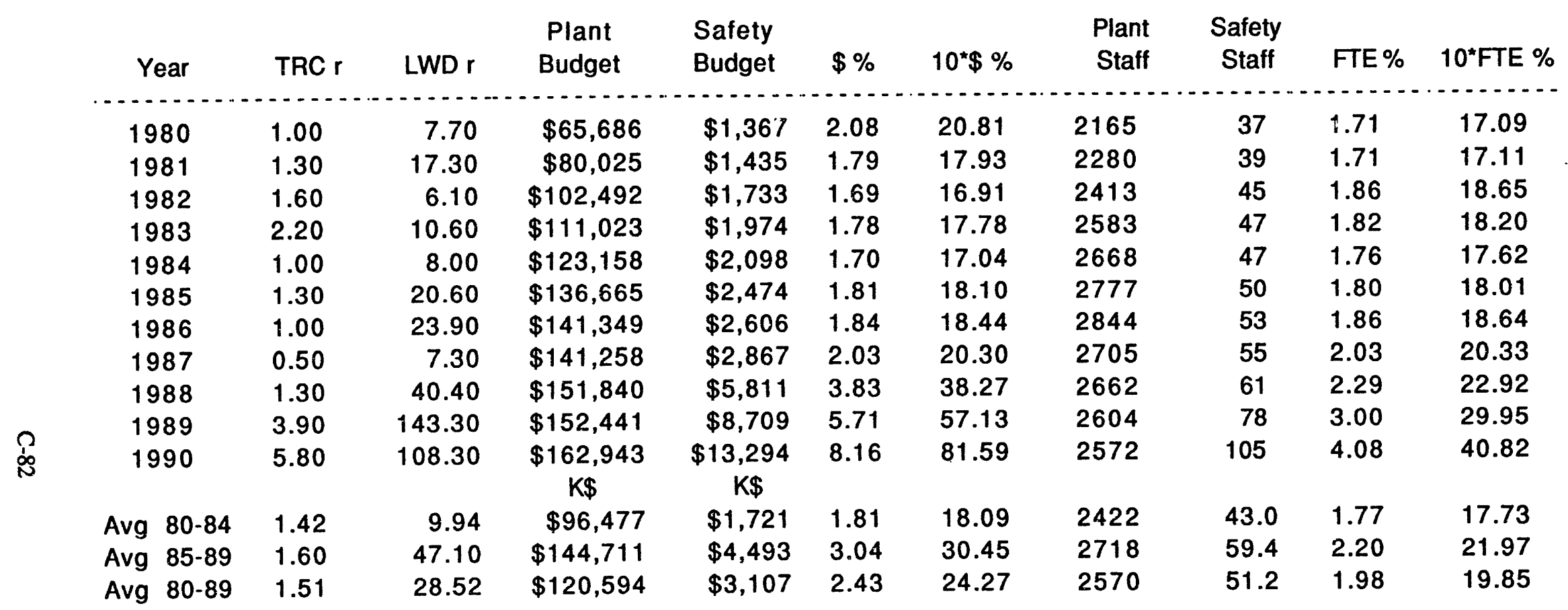


Table C10. (Cont.)

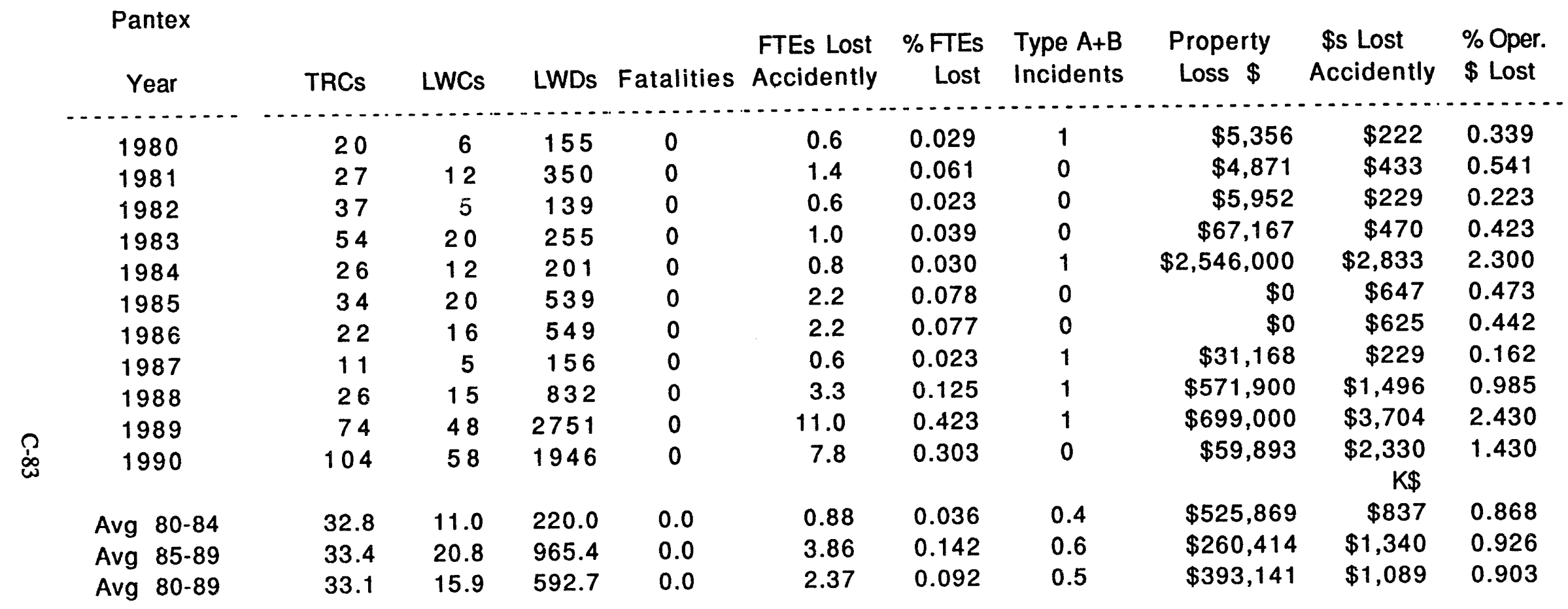


Table C10. (Cont.)

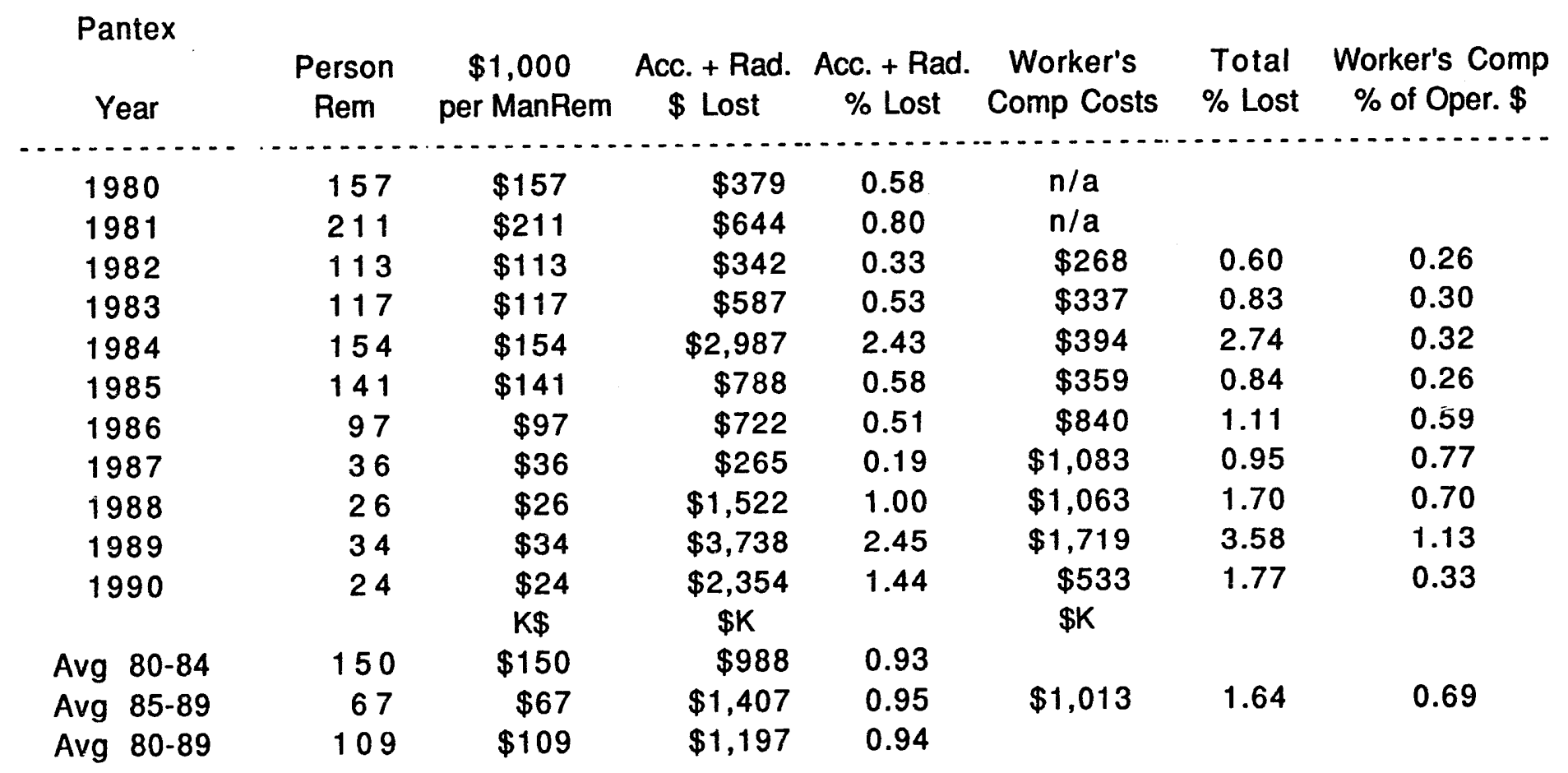




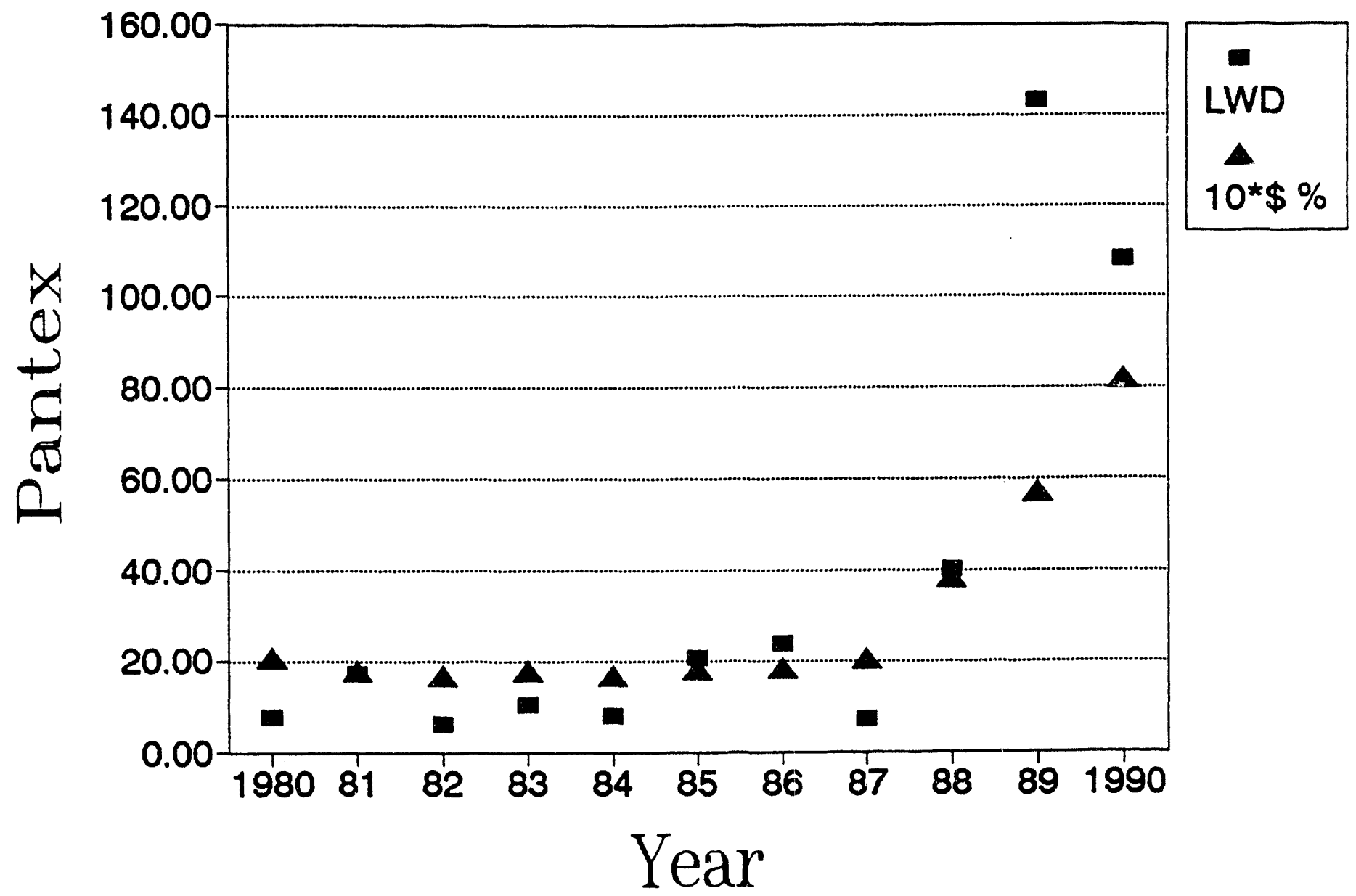

Figure C10.1. Lost workdays per $200 \mathrm{k}$ man-hr, 10 times safety budget percentage. 


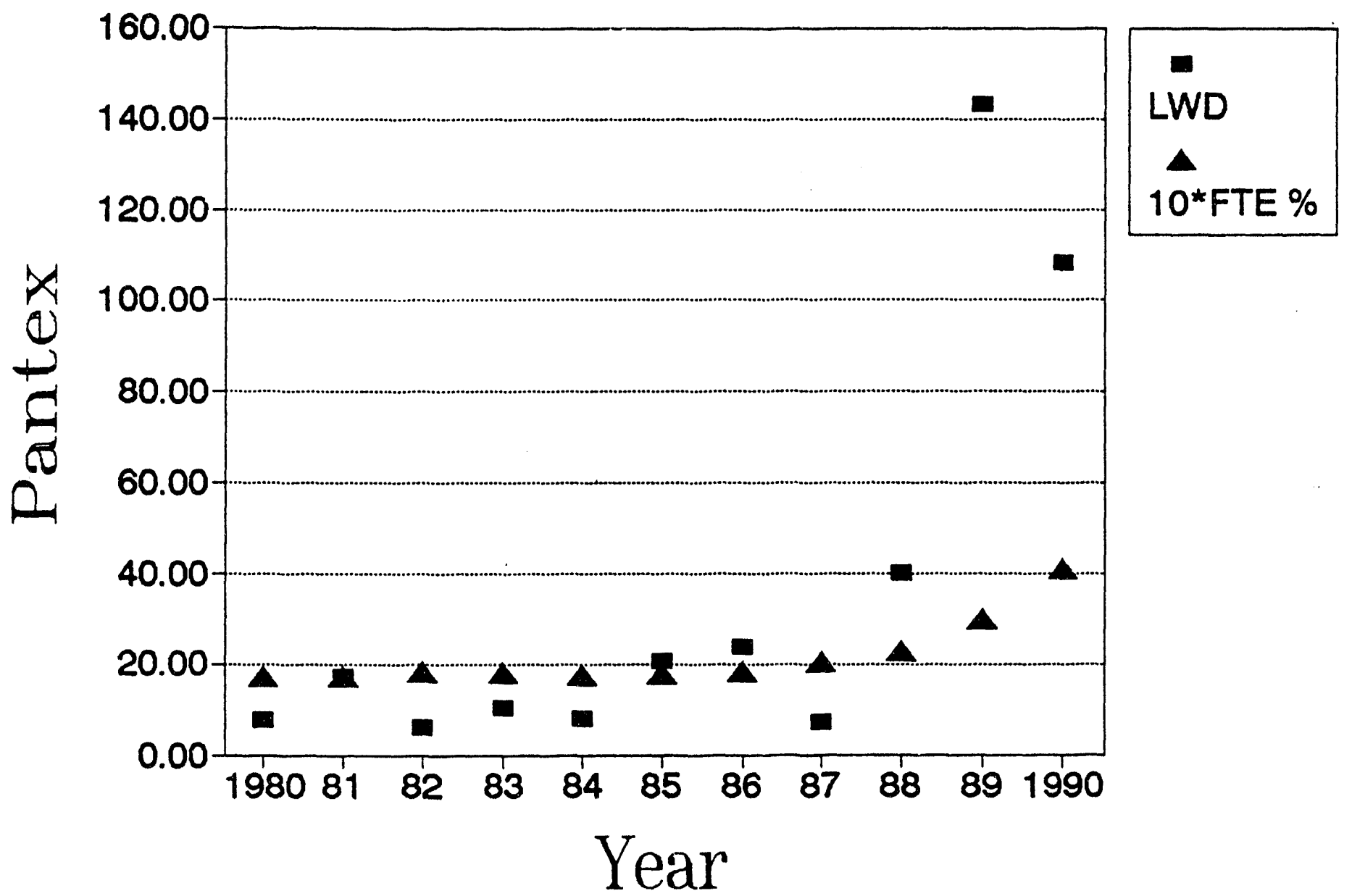

Figure C10.2. Lost workdays per $200 \mathrm{k}$ man-hr, 10 times safety manpower percentage. 


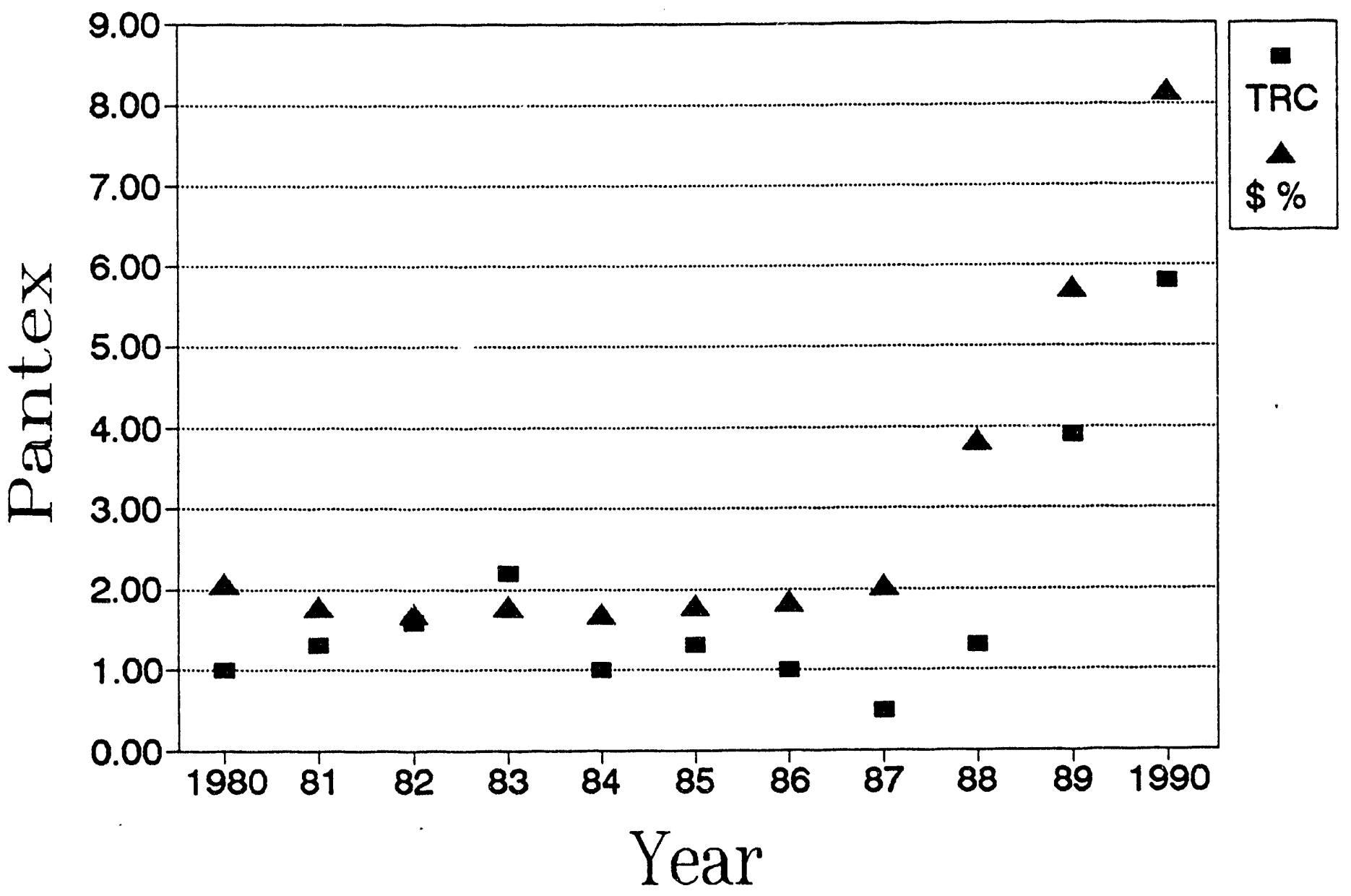

Figure C10.3. Total reportable case rate, percent of Plant budget spent on safety. 


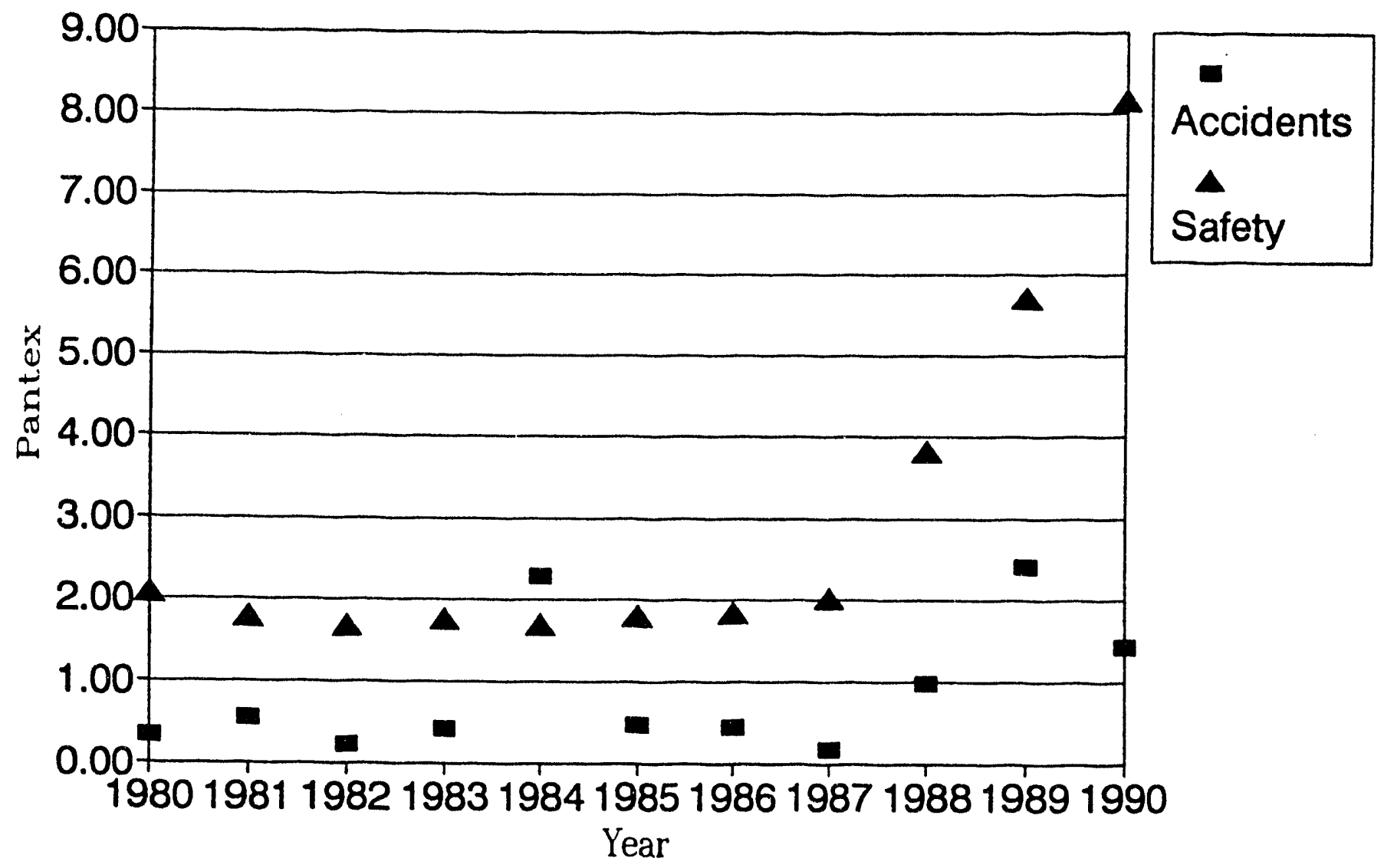

Figure C10.4. Percent of budget lost accidentally, percent of Plant budget spent on safety. 


\section{C11. Pinellas}

Pinellas is primarily a production facility. Worker's compensation data is unavailable prior to 1986 . The site changed its managing contractor in 1992. 
Table C11. Pinellas site data.

\begin{tabular}{|c|c|c|c|c|c|c|c|c|c|c|}
\hline Year & TRC r & LWD r & $\begin{array}{l}\text { Plant } \\
\text { Budget }\end{array}$ & $\begin{array}{l}\text { Safety } \\
\text { Budget }\end{array}$ & $\$ \%$ & $10 * \$ \%$ & $\begin{array}{l}\text { Plant } \\
\text { Staff }\end{array}$ & $\begin{array}{l}\text { Safety } \\
\text { Staff }\end{array}$ & FTE \% & $10^{\star}$ FTE\% \\
\hline & & & & & & & & & & \\
\hline 1980 & 0.40 & 1.50 & $\$ 57.6$ & $\$ 0.25$ & 0.43 & 4.29 & 1521 & 9 & 0.59 & 5.92 \\
\hline 1981 & 0.20 & 0.00 & $\$ 67.7$ & $\$ 0.29$ & 0.42 & 4.22 & 1586 & 9 & 0.57 & 5.67 \\
\hline 1982 & 0.30 & 0.00 & $\$ 86.6$ & $\$ 0.35$ & 0.40 & 4.04 & 1745 & 9 & 0.52 & 5.16 \\
\hline 1983 & 0.40 & 5.90 & $\$ 99.6$ & $\$ 0.45$ & 0.45 & 4.49 & 1849 & 11 & 0.59 & 5.95 \\
\hline 1984 & 0.30 & 4.60 & $\$ 111.4$ & $\$ 0.56$ & 0.50 & 5.00 & 1909 & 12 & 0.63 & 6.29 \\
\hline 1985 & 0.50 & 8.30 & $\$ 119.5$ & $\$ 0.99$ & 0.83 & 8.26 & 1980 & 14 & 0.71 & 7.07 \\
\hline 1986 & 0.30 & 0.90 & $\$ 119.2$ & $\$ 0.93$ & 0.78 & 7.83 & 1973 & 14 & 0.71 & 7.10 \\
\hline 1987 & 1.60 & 10.10 & $\$ 118.5$ & $\$ 0.97$ & 0.82 & 8.18 & 1875 & 13 & 0.69 & 6.93 \\
\hline 1988 & 3.00 & 6.50 & $\$ 119.7$ & $\$ 1.47$ & 1.22 & 12.25 & 1710 & 22 & 1.29 & 12.87 \\
\hline 1989 & 2.30 & 22.30 & $\$ 119.3$ & $\$ 1.53$ & 1.28 & 12.80 & 1701 & 20 & 1.18 & 11.76 \\
\hline 1990 & 5.00 & 28.10 & $\$ 123.9$ & $\$ 1.80$ & 1.46 & 14.56 & 1671 & 22 & 1.32 & 13.17 \\
\hline & & & $M \$$ & $M \$$ & & & & & & \\
\hline Avg $80-84$ & 0.32 & 2.40 & $\$ 84.6$ & $\$ 0.38$ & 0.44 & 4.41 & 1722.0 & 160 & 0.58 & 5.80 \\
\hline Avg $85-89$ & 1.54 & 9.62 & $\$ 119.2$ & $\$ 1.18$ & 0.99 & 9.86 & 1847.8 & 16.6 & 0.91 & 9.14 \\
\hline Avg $80-89$ & 0.93 & 6.01 & $\$ 101.9$ & $\$ 0.78$ & 0.71 & 7.14 & 1784.9 & 13.3 & 0.75 & 7.47 \\
\hline
\end{tabular}




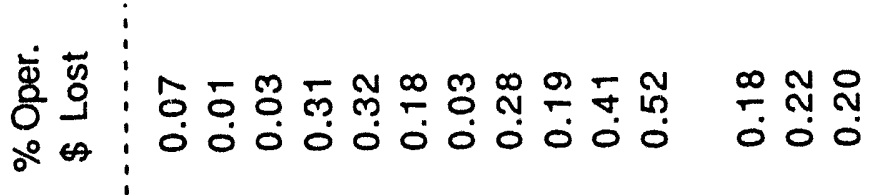

웅ํㅇㅇㅇㅛ

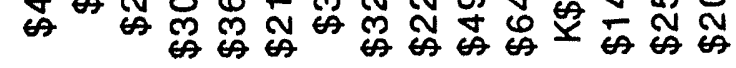

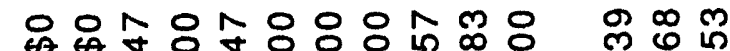

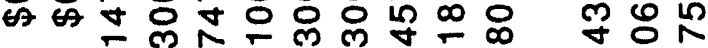

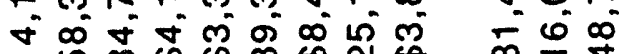

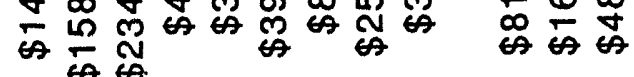

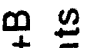

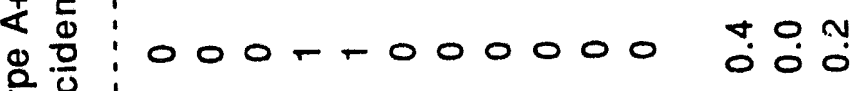
는 은

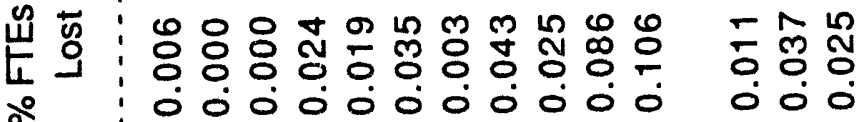
๙̊

$\overline{0} \geq$

in 응

出 $\frac{0}{0}$

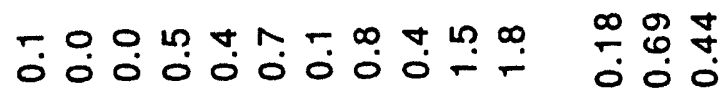

ए厂

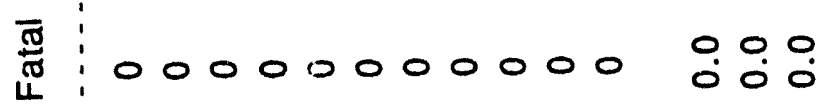

雚:

J

岂

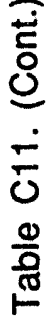

\& $\$$ 요

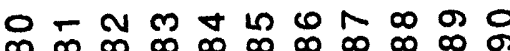
罡

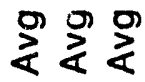


Table C11. (Cont.)

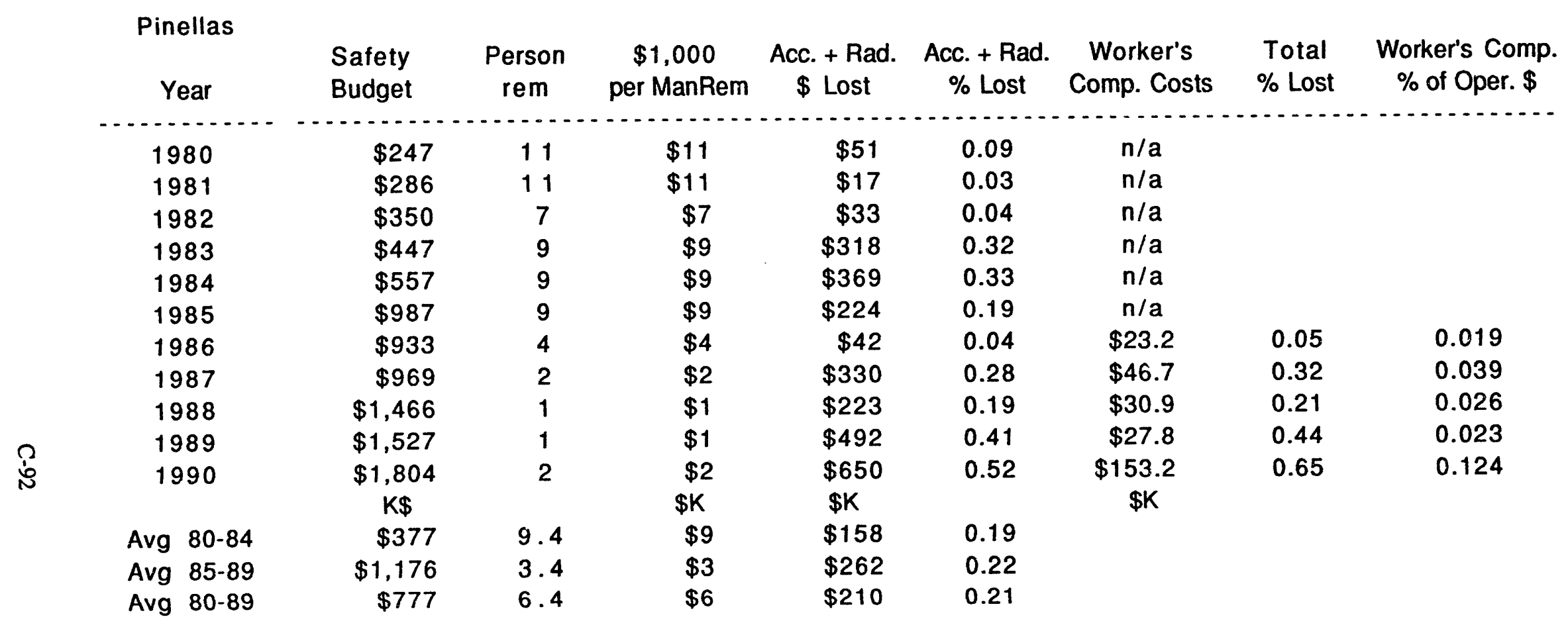




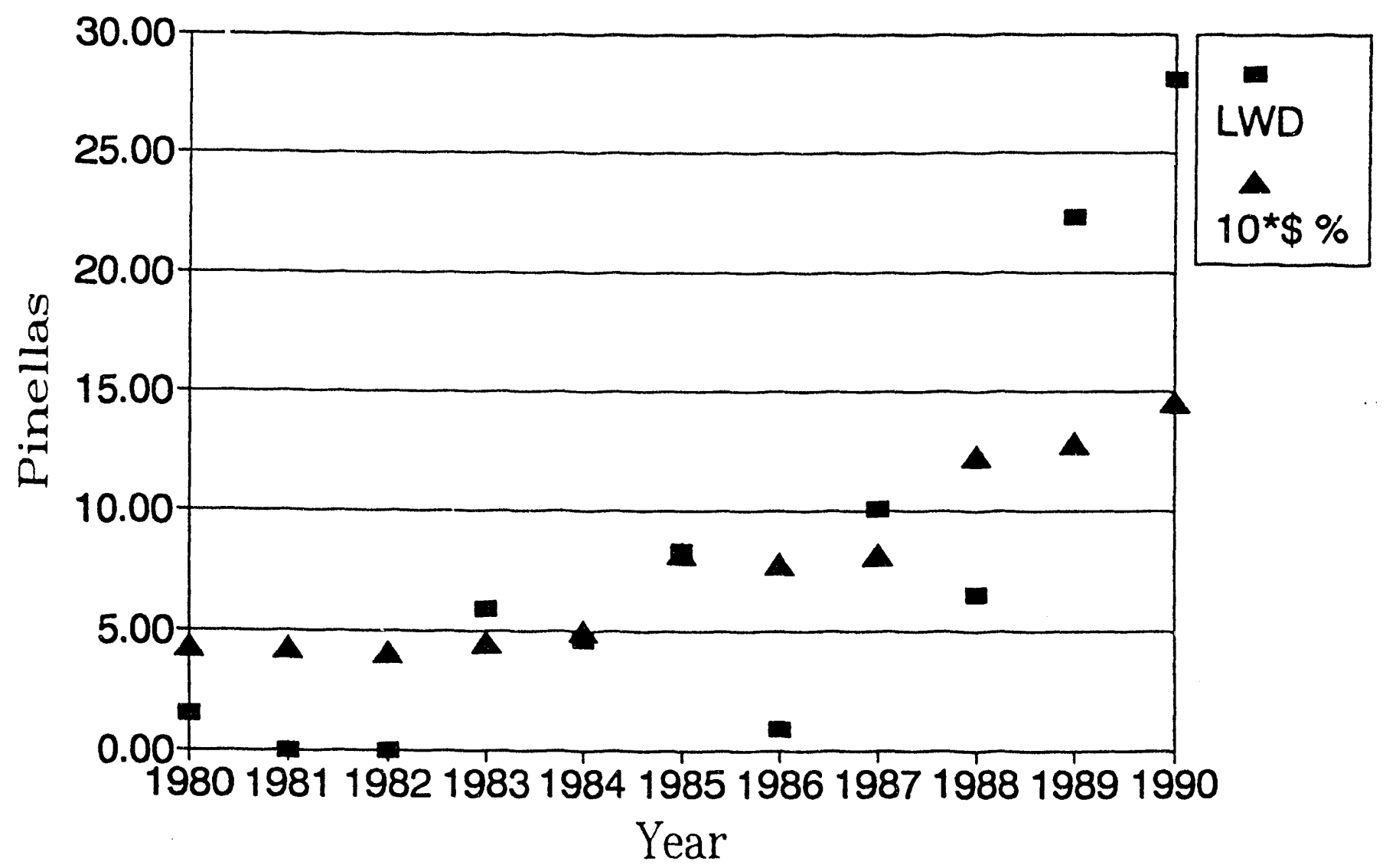

Figure C11.1. Lost workdays per 200k man-hr, 10 times safety budget percentage. 


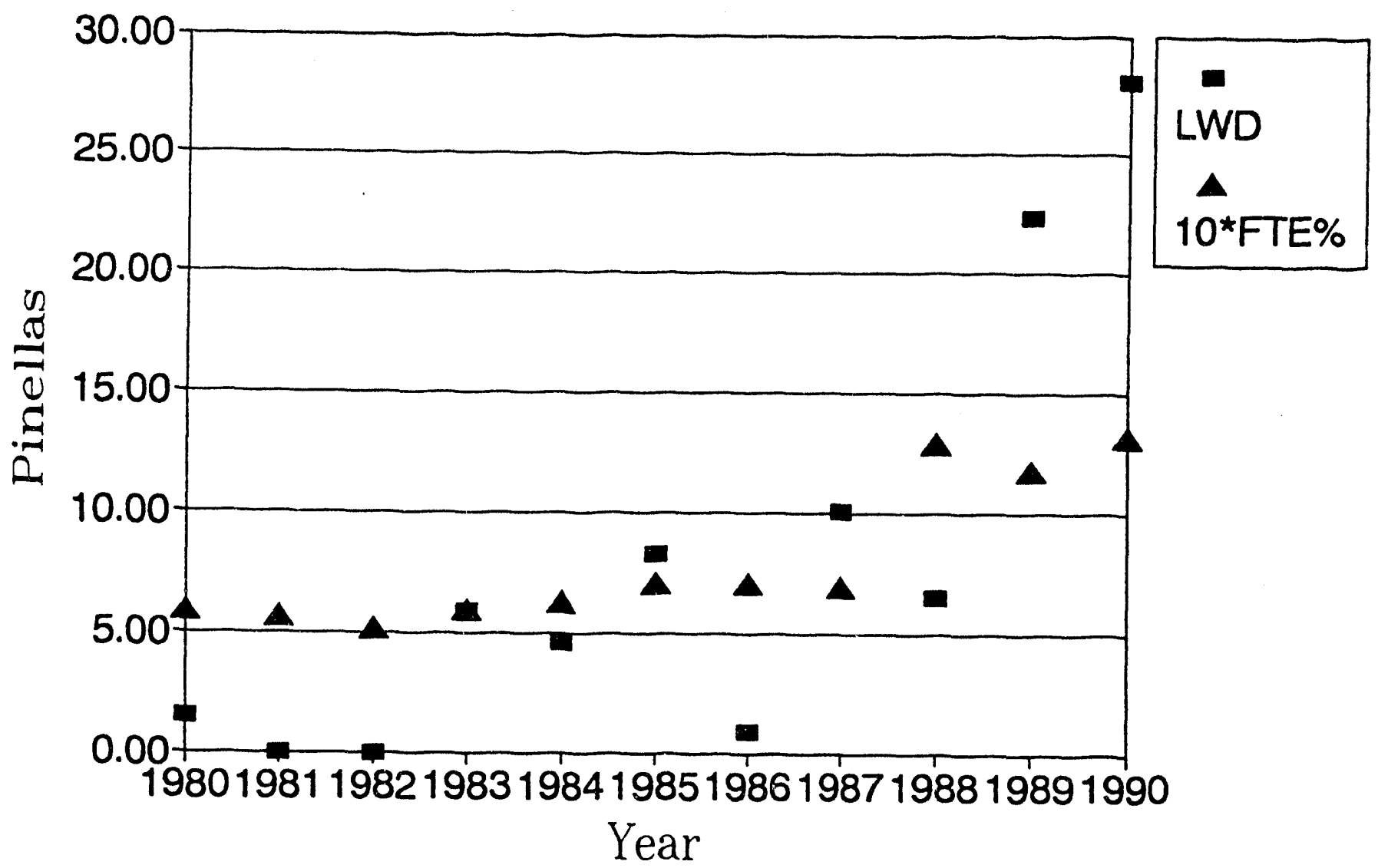

Figure C11.2. Lost workdays per $200 \mathrm{k}$ man-hr, 10 times safety manpower percentage. 


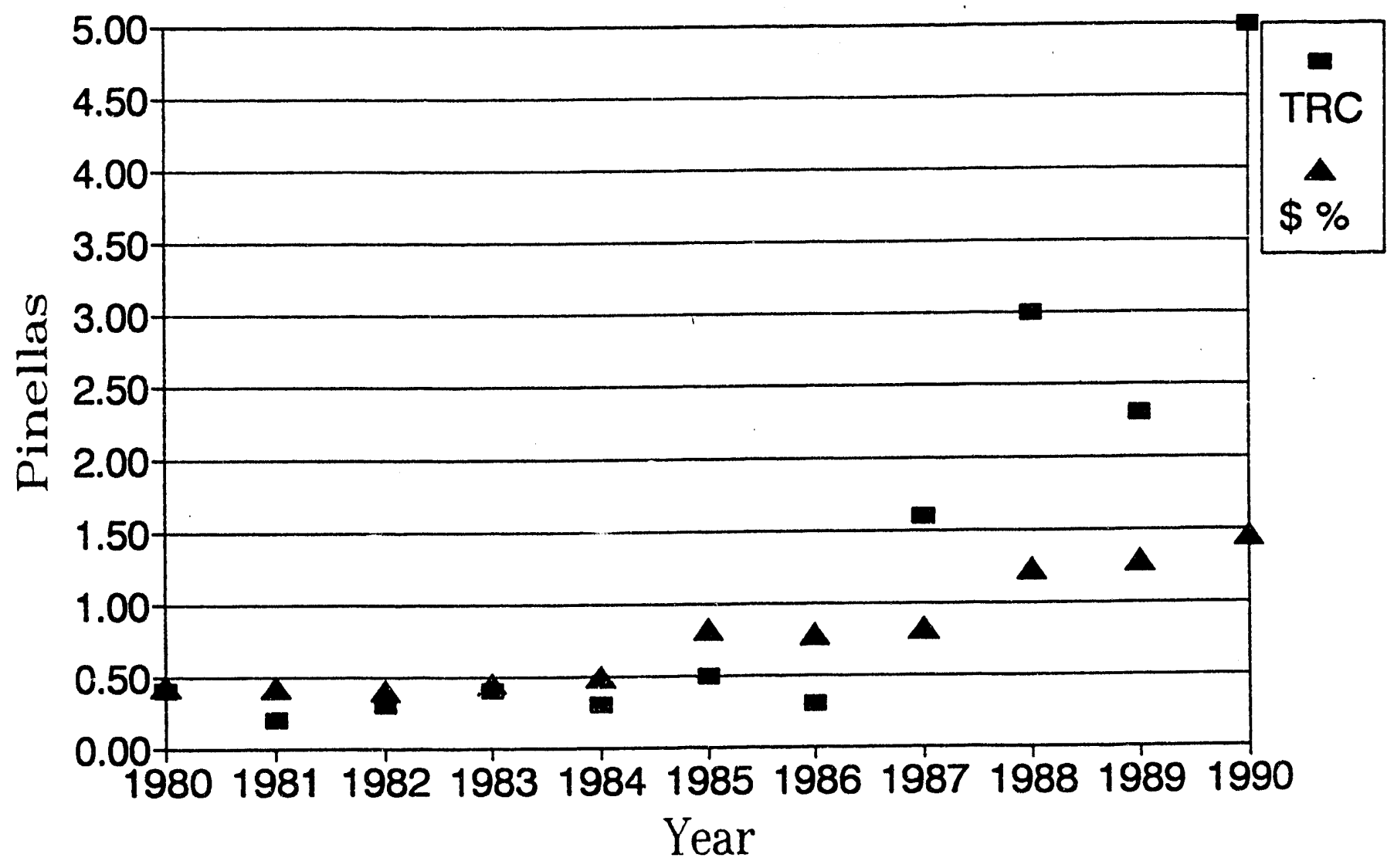

Figure C11.3. Total reportable case rate, percent of Plant budget spent on safety. 


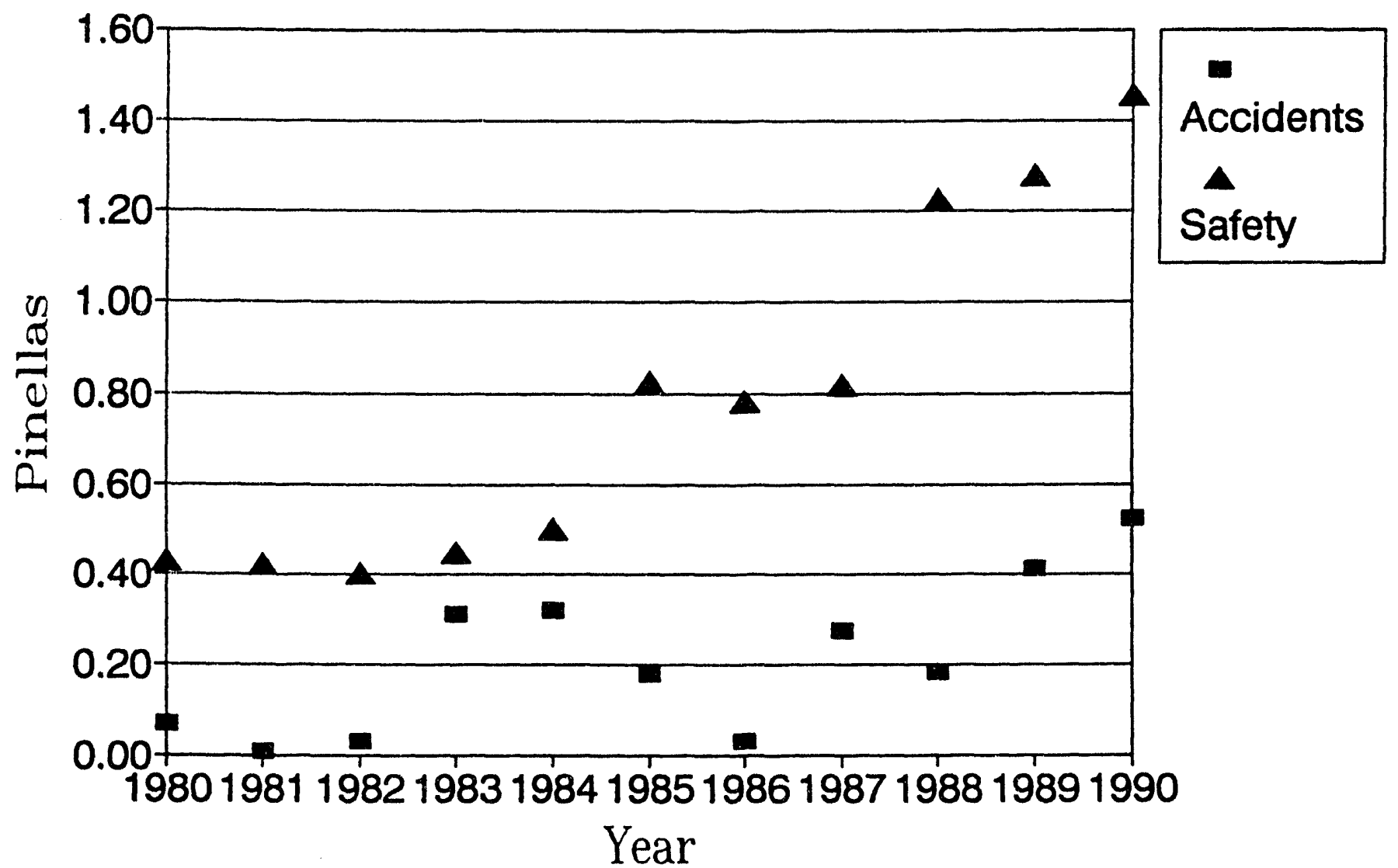

Figure C11.4. Percent of budget lost accidentally, percent of Plant budget spent on safety. 


\section{C12. Sandia}

Sandia is a multiprogram national R\&D laboratory. It hired additional safety staff in 1988 and found that it had been under-reporting injuries and LWD. Its improved reporting has come about by establishing better reporting ties with medical and payroll. The step increase is obvious in Fig. C12.1. The site separated security figures in 1987. A Tiger Team appraisal was condıcted in May 1991. No worker's compensation data is available prior to 1986. 
Table C12. Sandia site data.

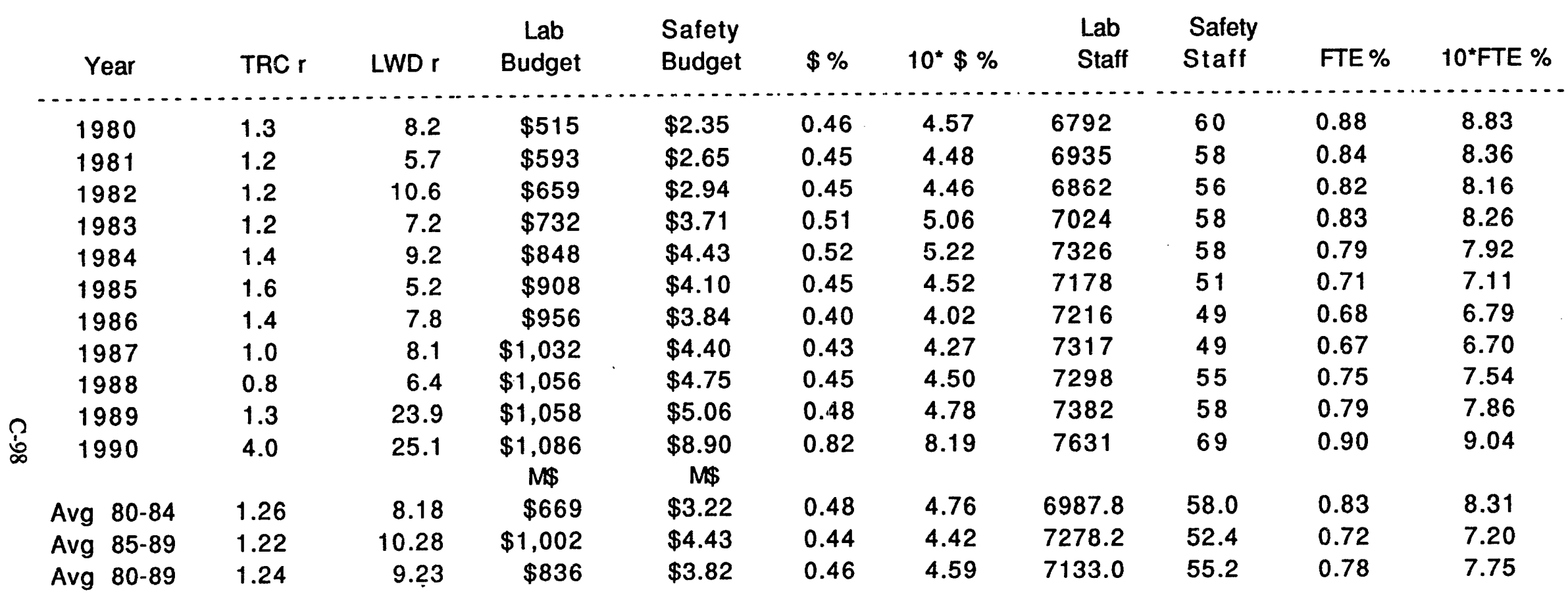


Table C12. (Cont.)

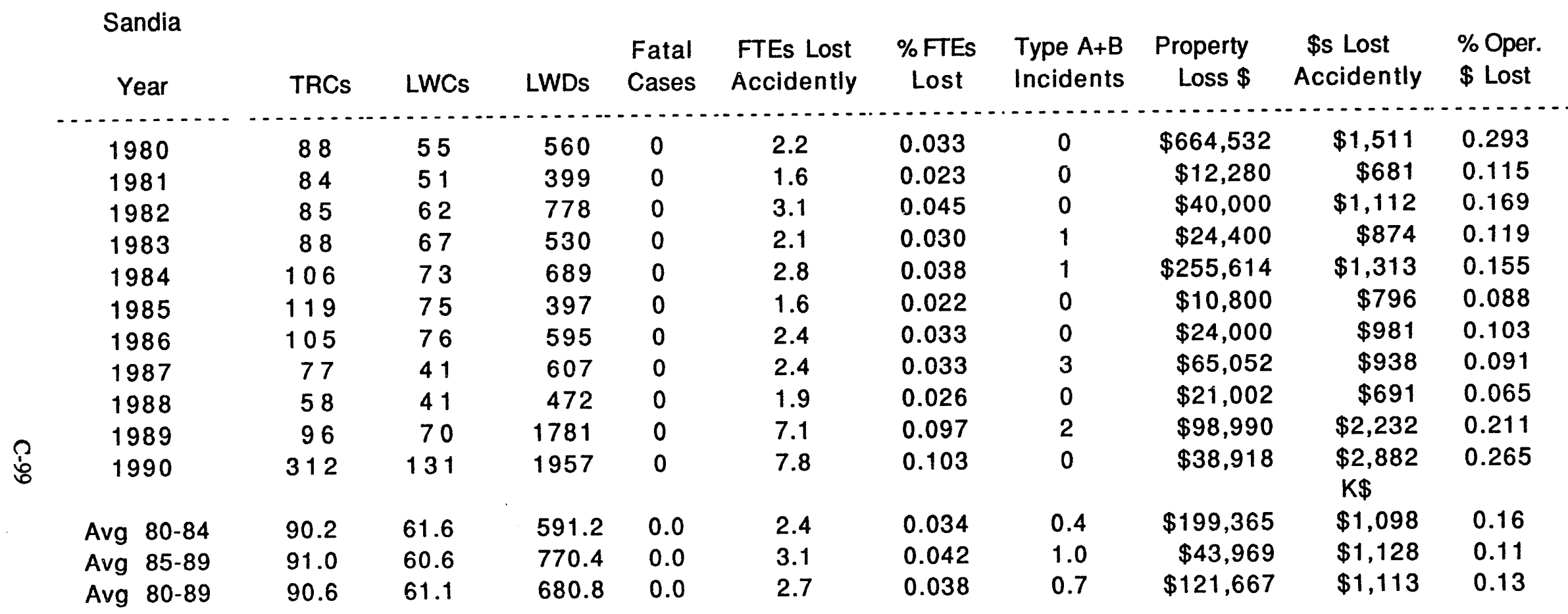


Table C12. (Cont.)

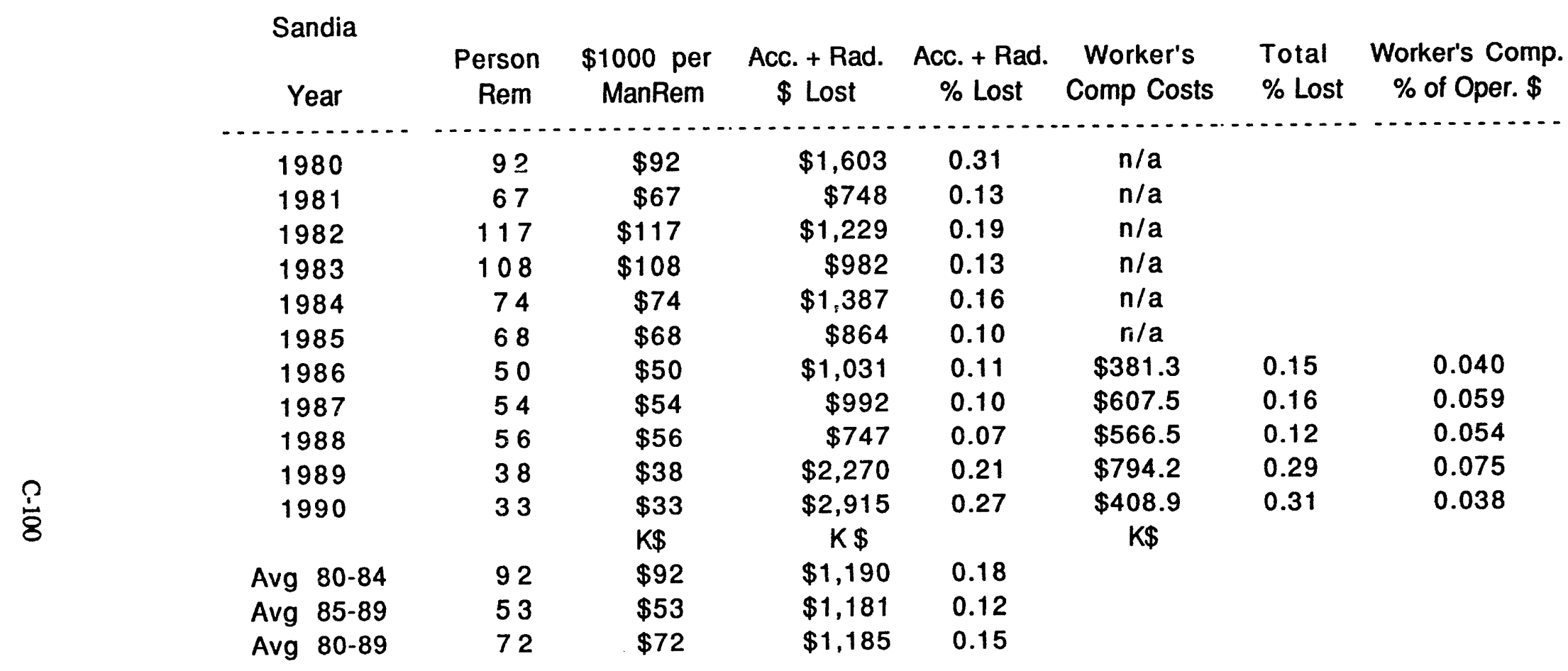




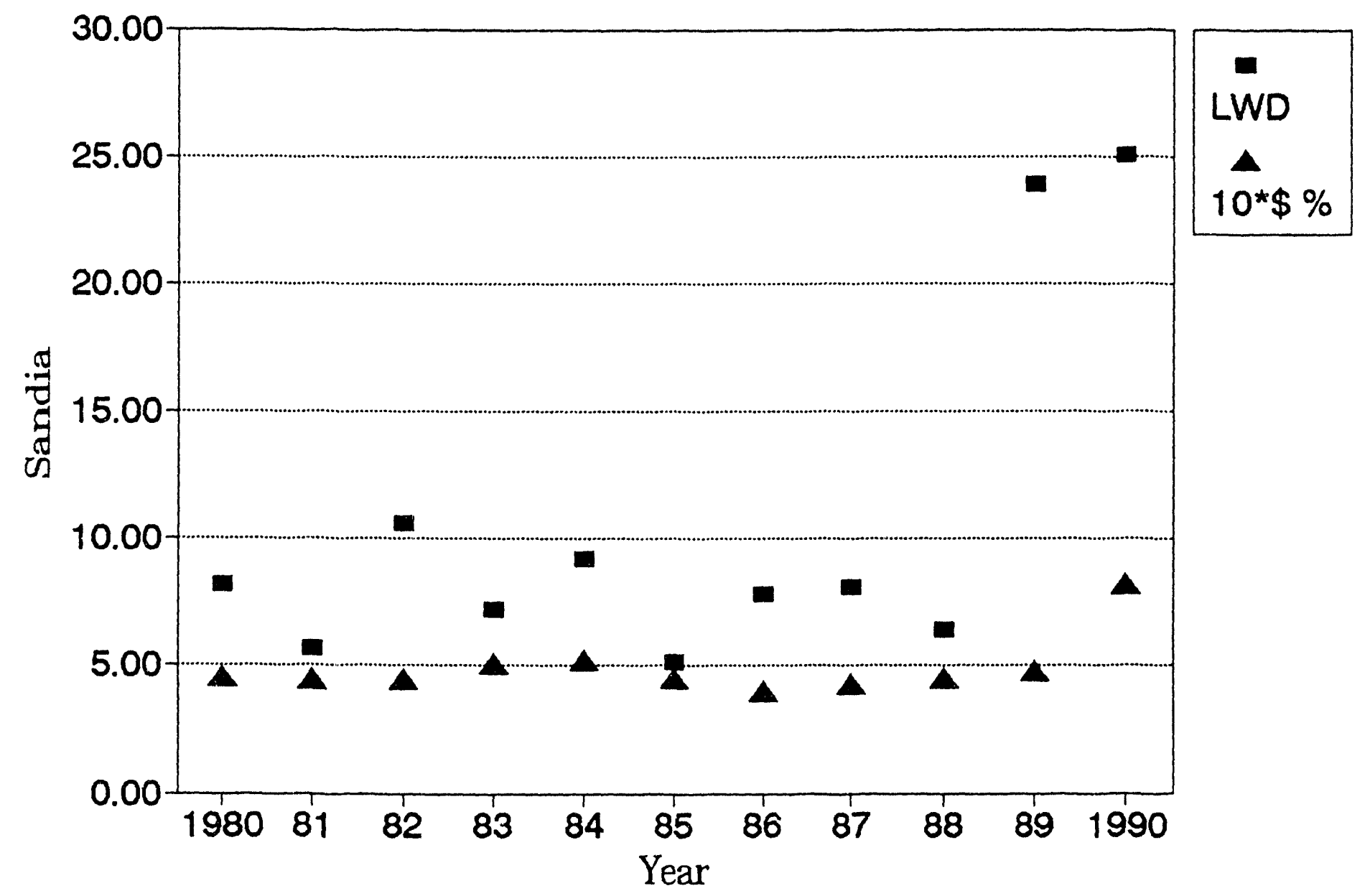

Figure C12.1. Lost workdays per $200 \mathrm{k}$ man-hr, 10 times safety budget percentage. 


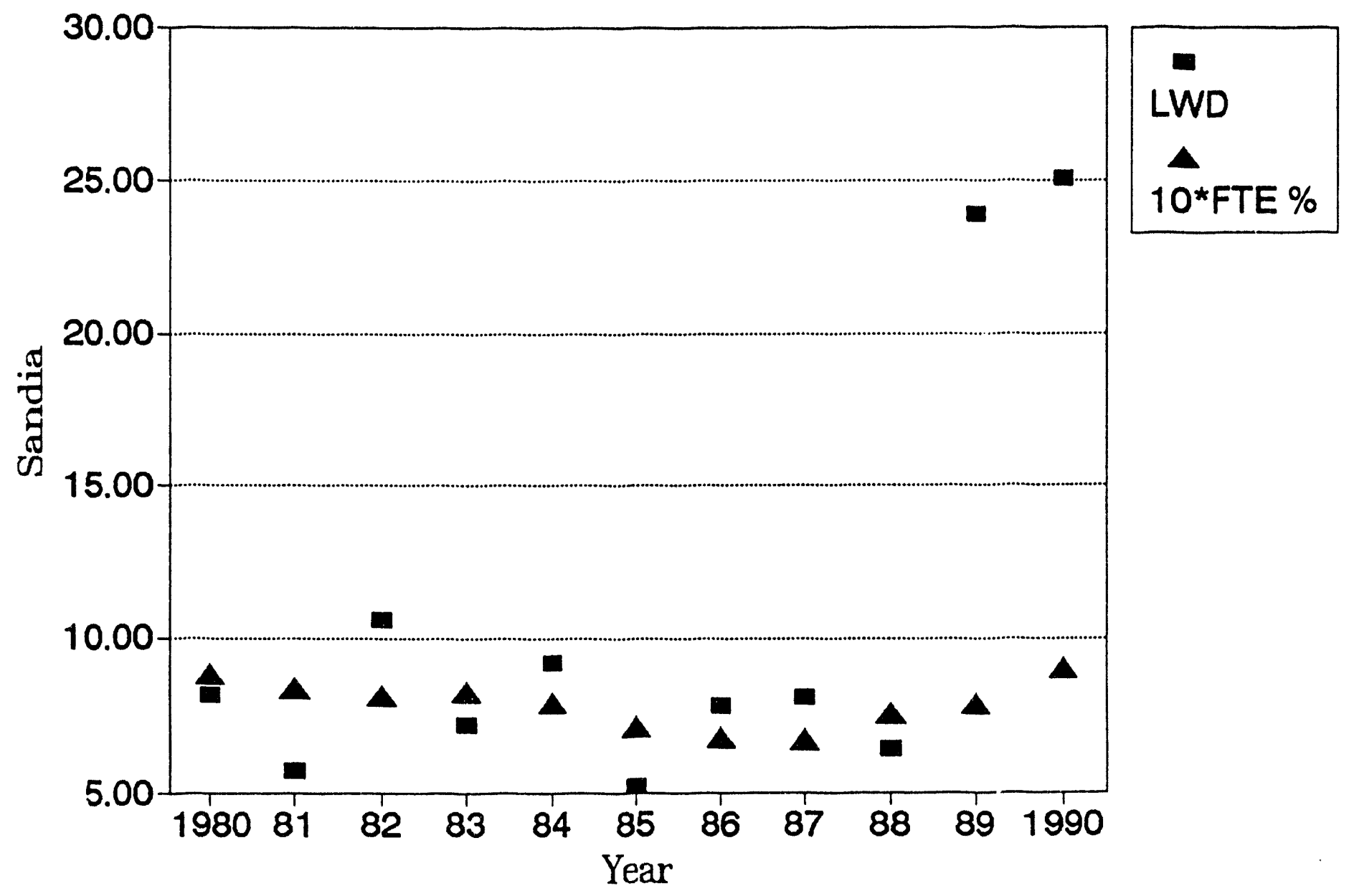

Figure C12.2. Lost workdays per 200k man-hr, 10 times safety manpower percentage. 


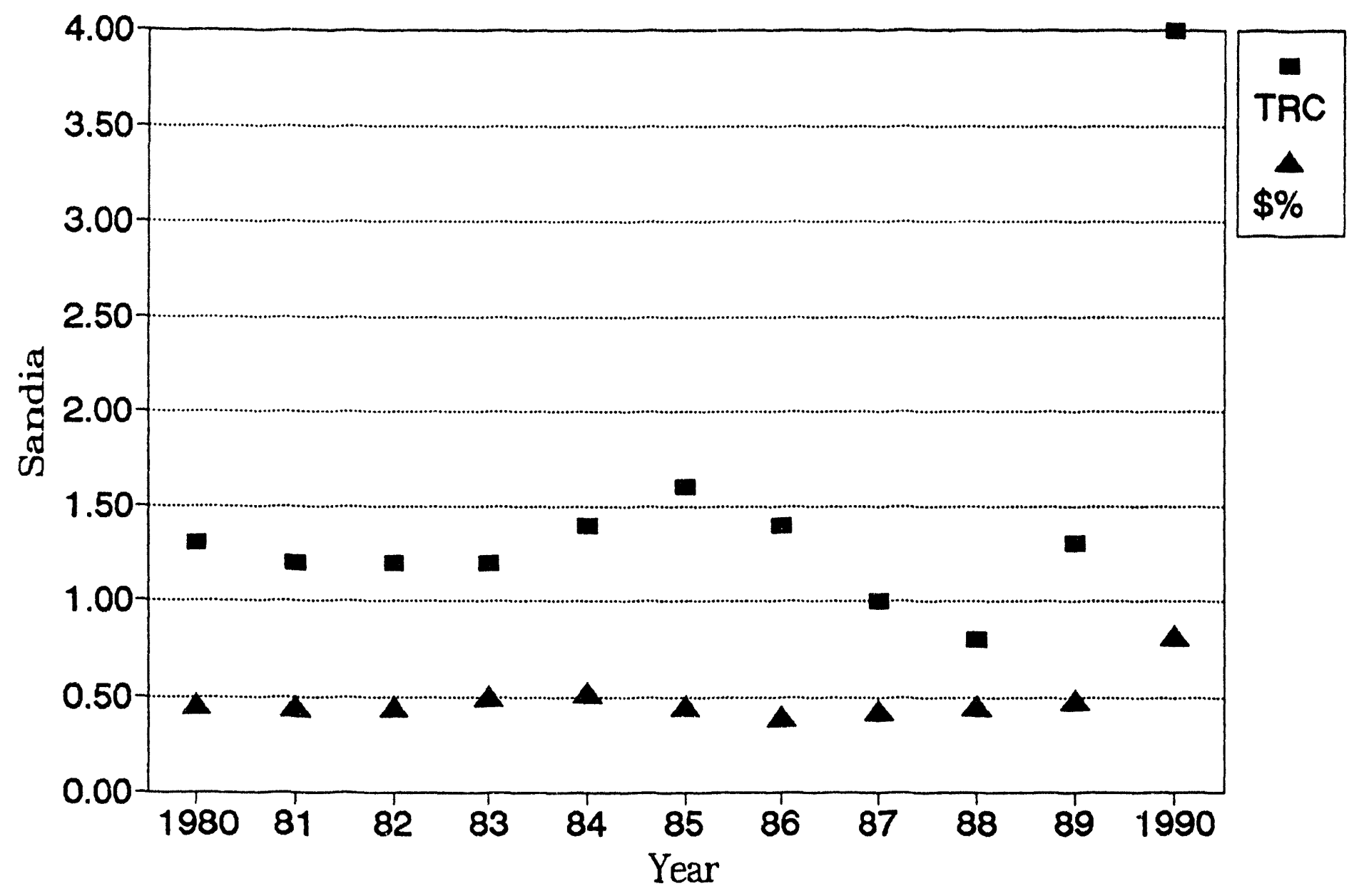

Figure C12.3. Total reportable case rate, percent of Laboratory budget spent on safety. 


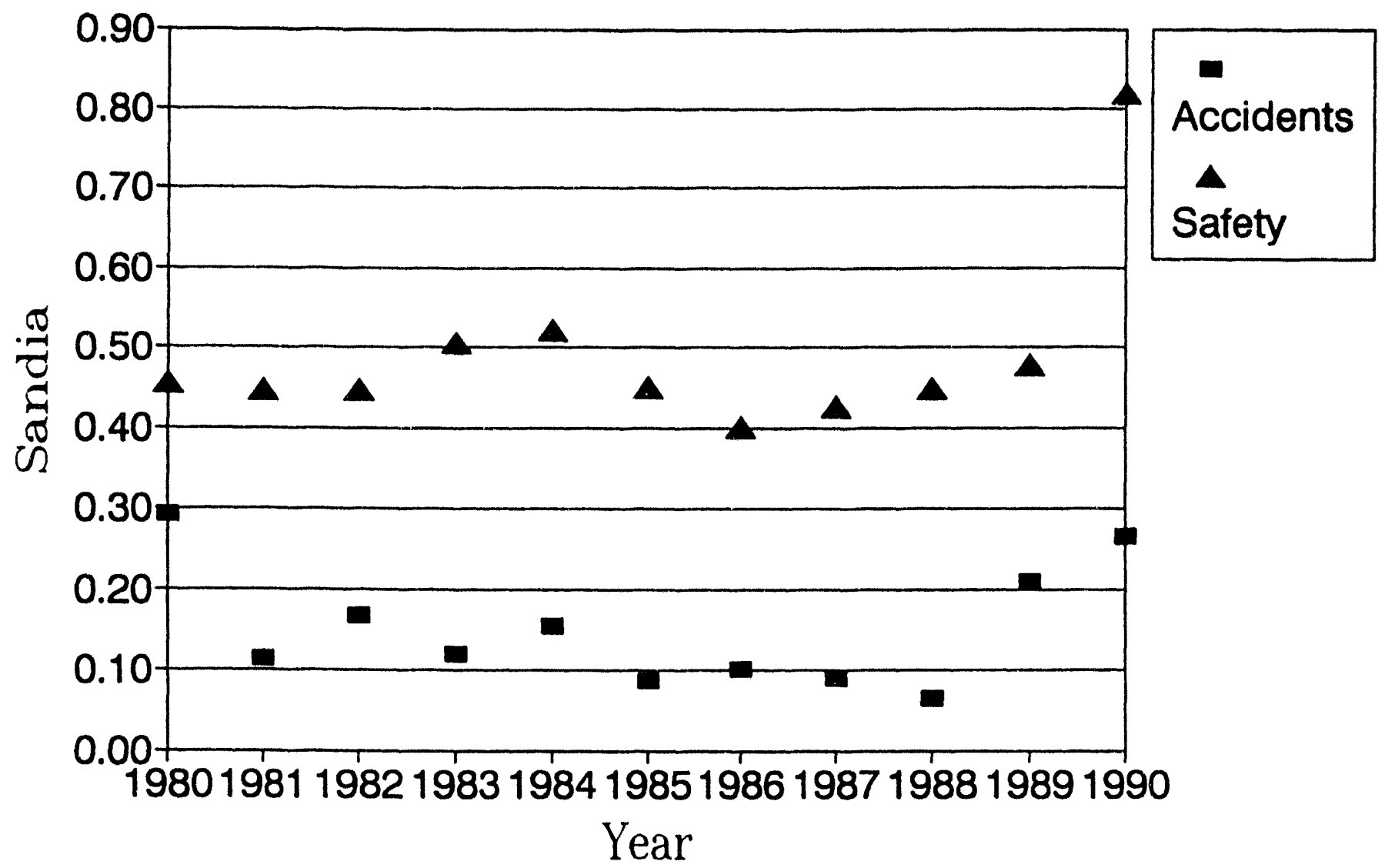

Figure C12.4. Percent of budget lost accidentally, percent of Laboratory budget spent on safety. 
C13. Y-12

Y-12 is primarily a production facility. There was a change of managing contractor, from Union Carbide to Martin Marietta, in 1984. Y-12 went to full BLS reporting in 1990, but a single year is too early to determine whether a step change has occurred. Values for 1991 were reported to be lower than for 1990, but still higher than the previous trend. A Tiger Team appraisal was conducted in September 1989. The site was unable to obtain worker's compensation data prior to 1982. 
Table C13. Y-12 site data.

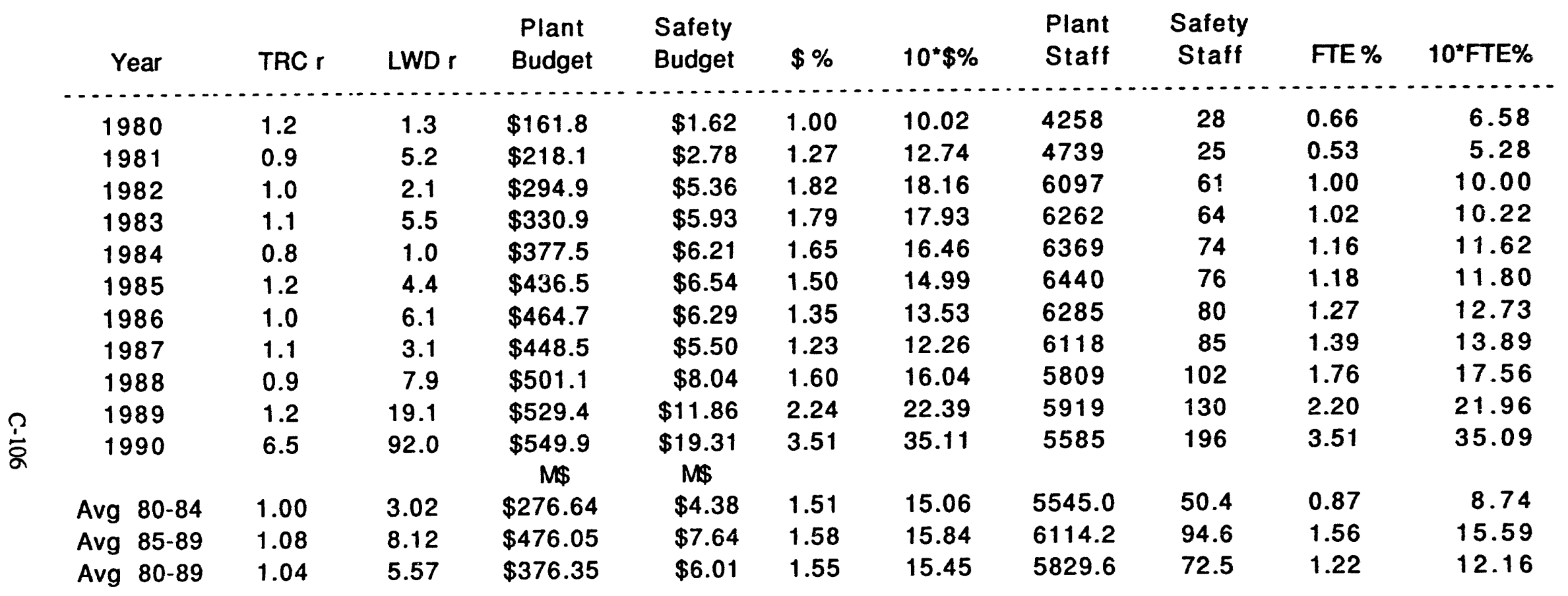


Table C13. (Cont.)

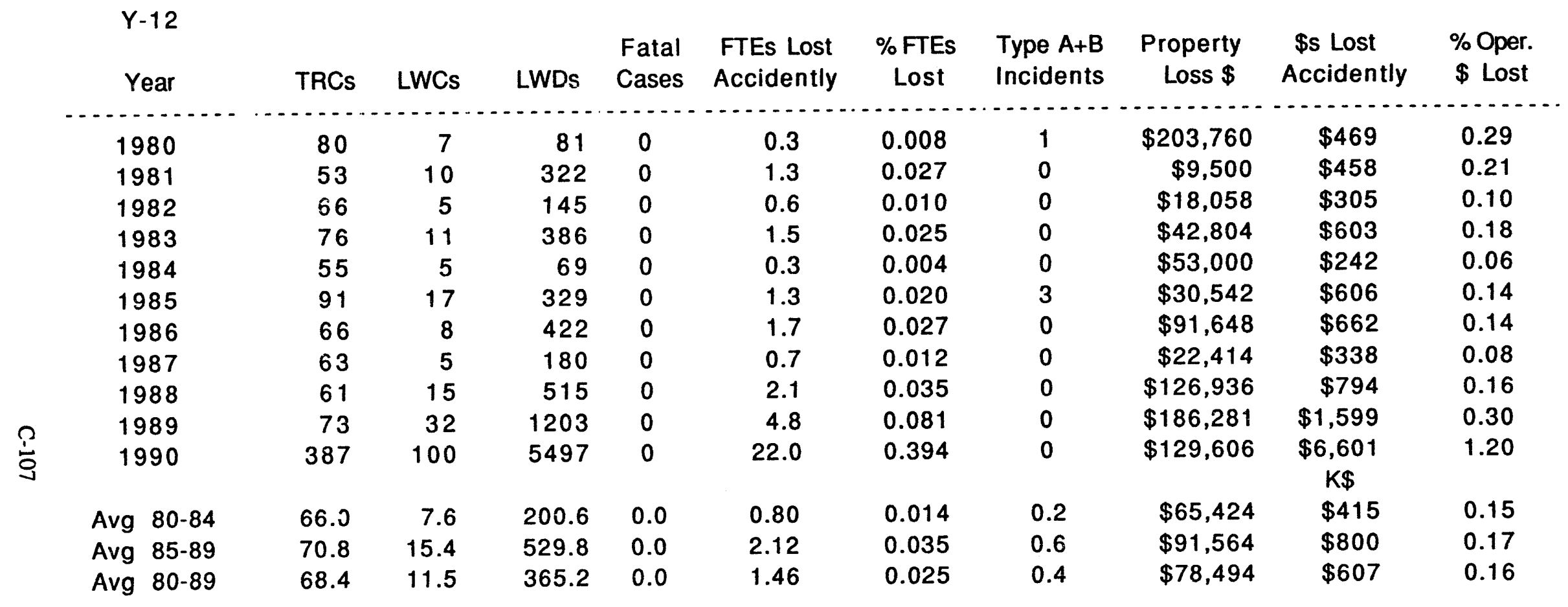


Table C13. (Cont.)

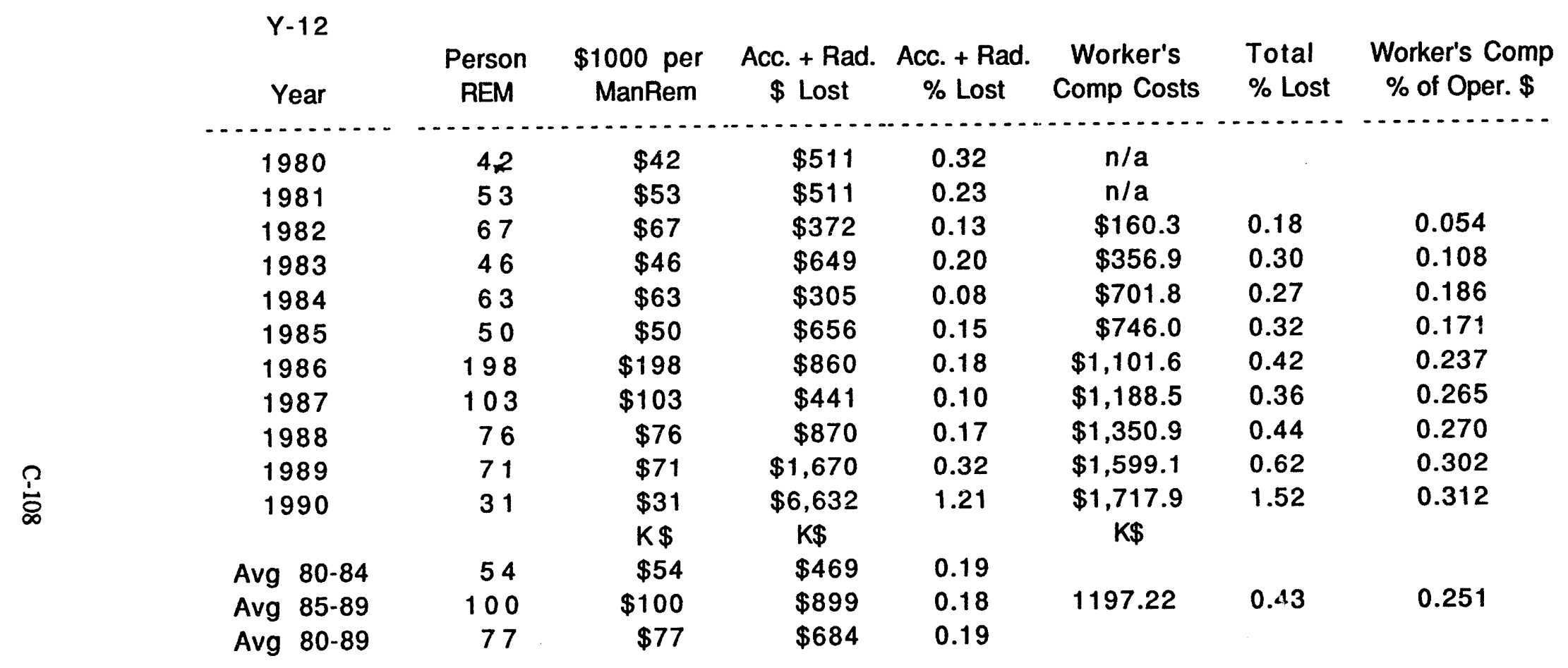




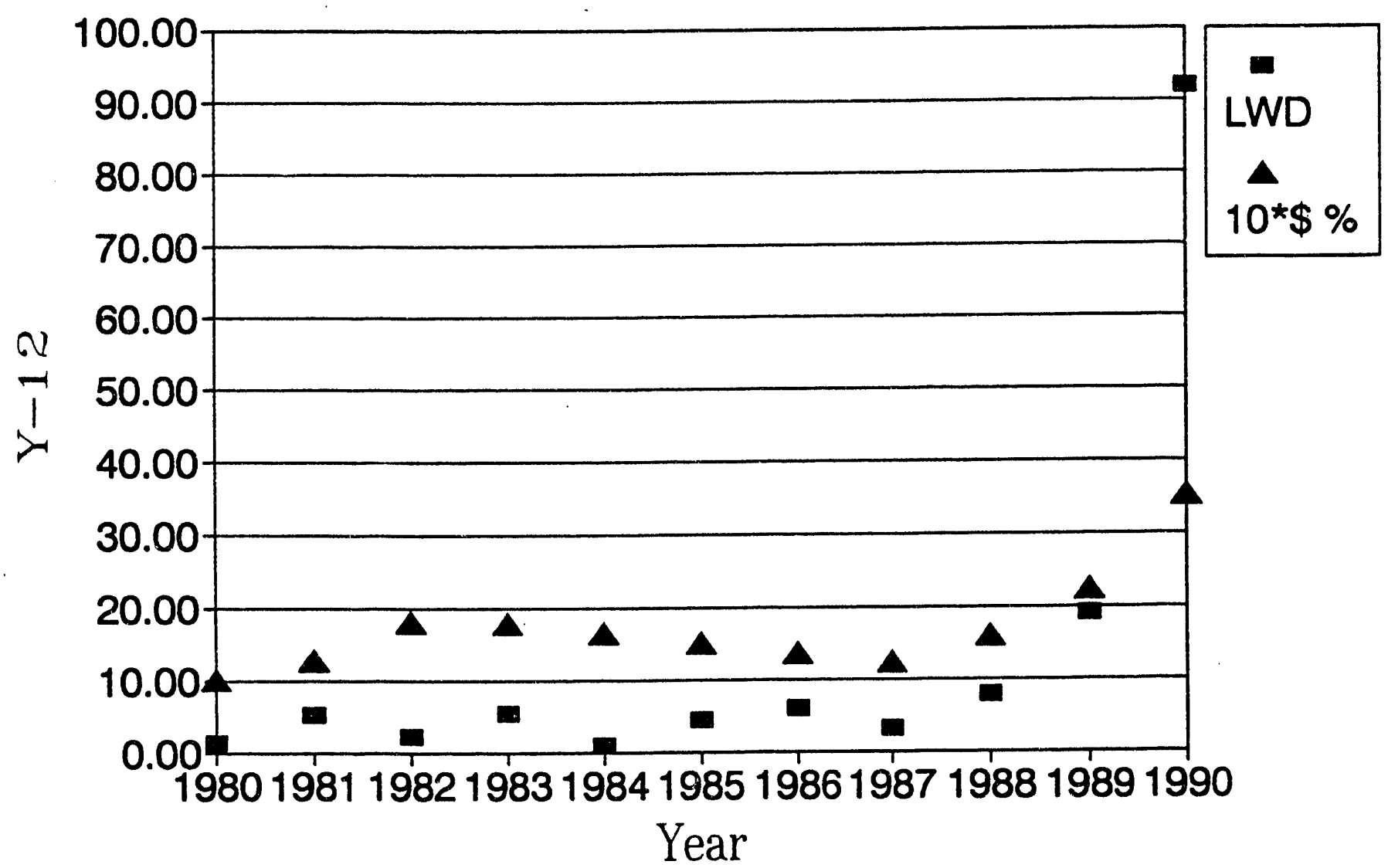

Figure C13.1. Lost workdays per $200 \mathrm{k}$ man-hr, 10 times safety budget percentage. 


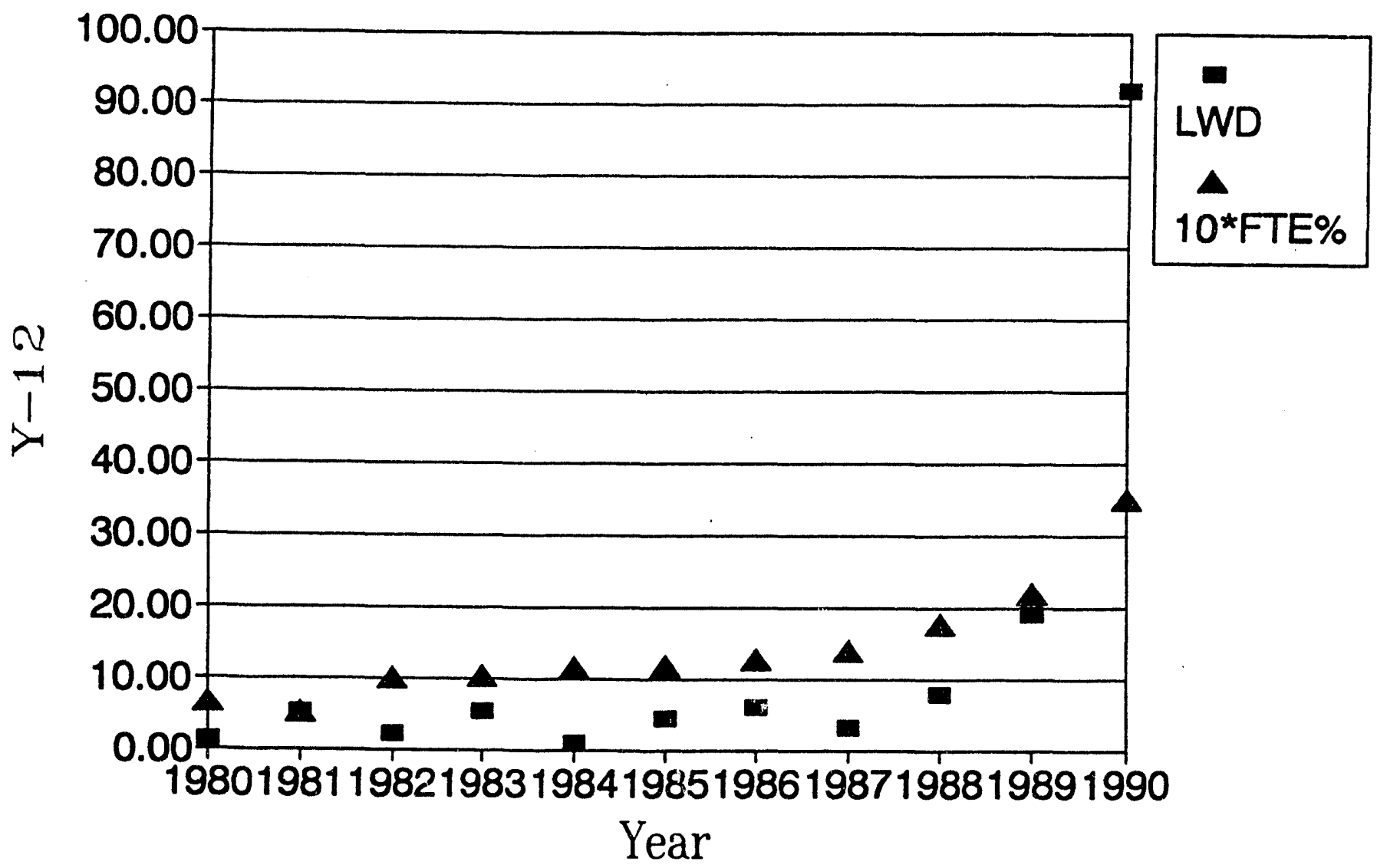

Figure C13.2. Lost workdays per 200k man-hr, 10 times safety manpower percentage. 


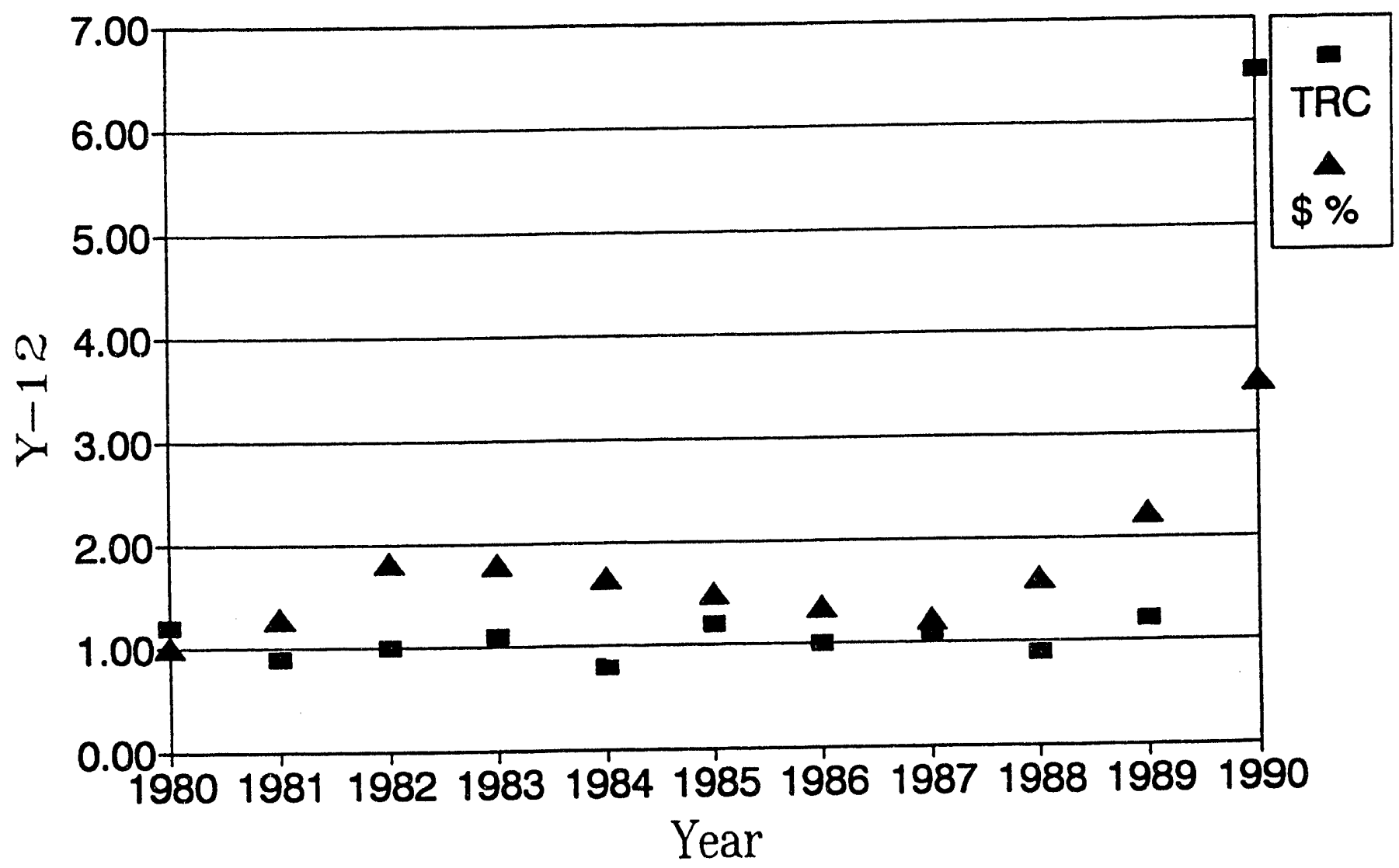

Figure C13.3. Total reportable case rate, percent of Plant budget spent on safety. 


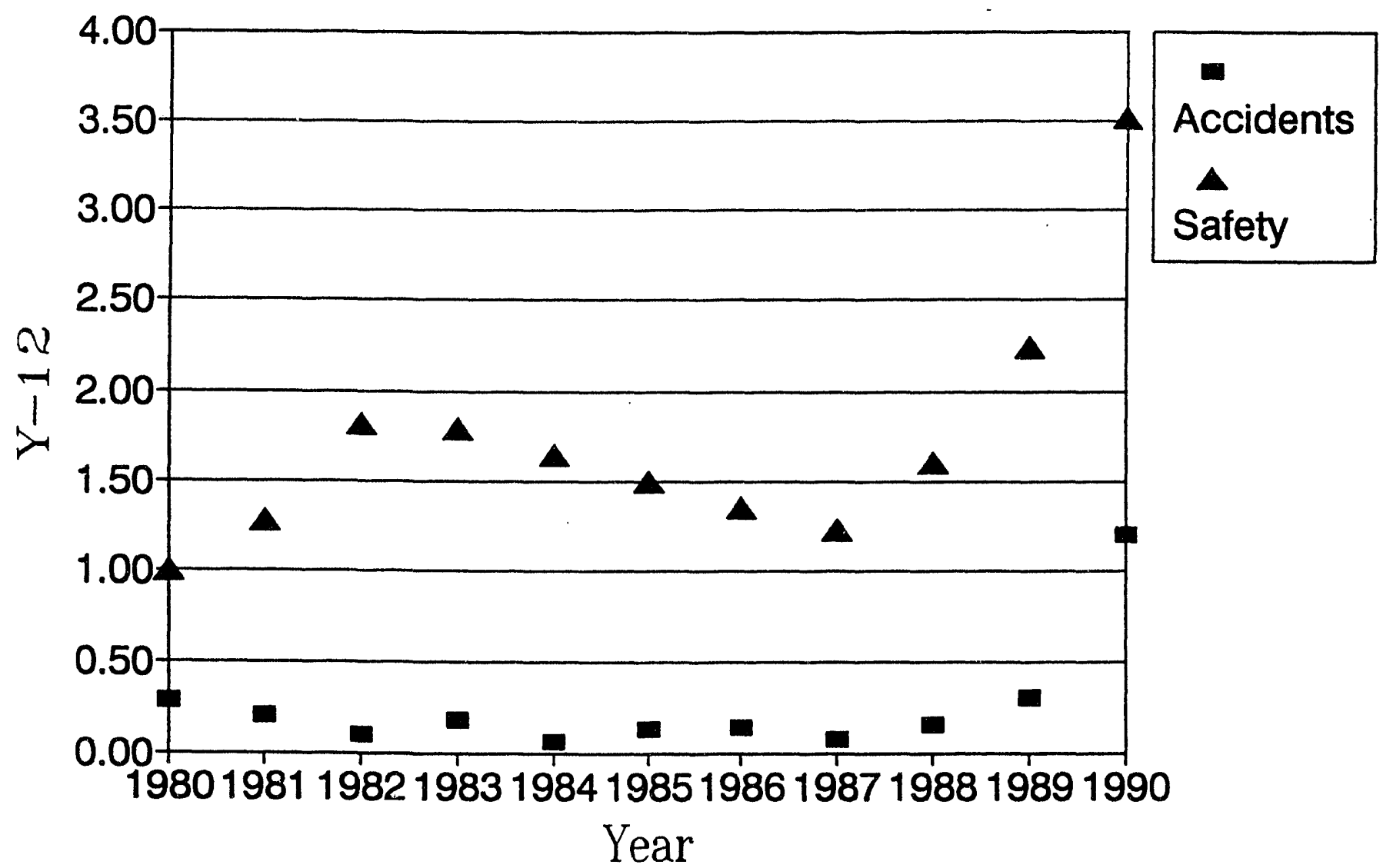

Figure C13.4. Percent of budget lost accidentally, percent of Plant budget spent on safety. 

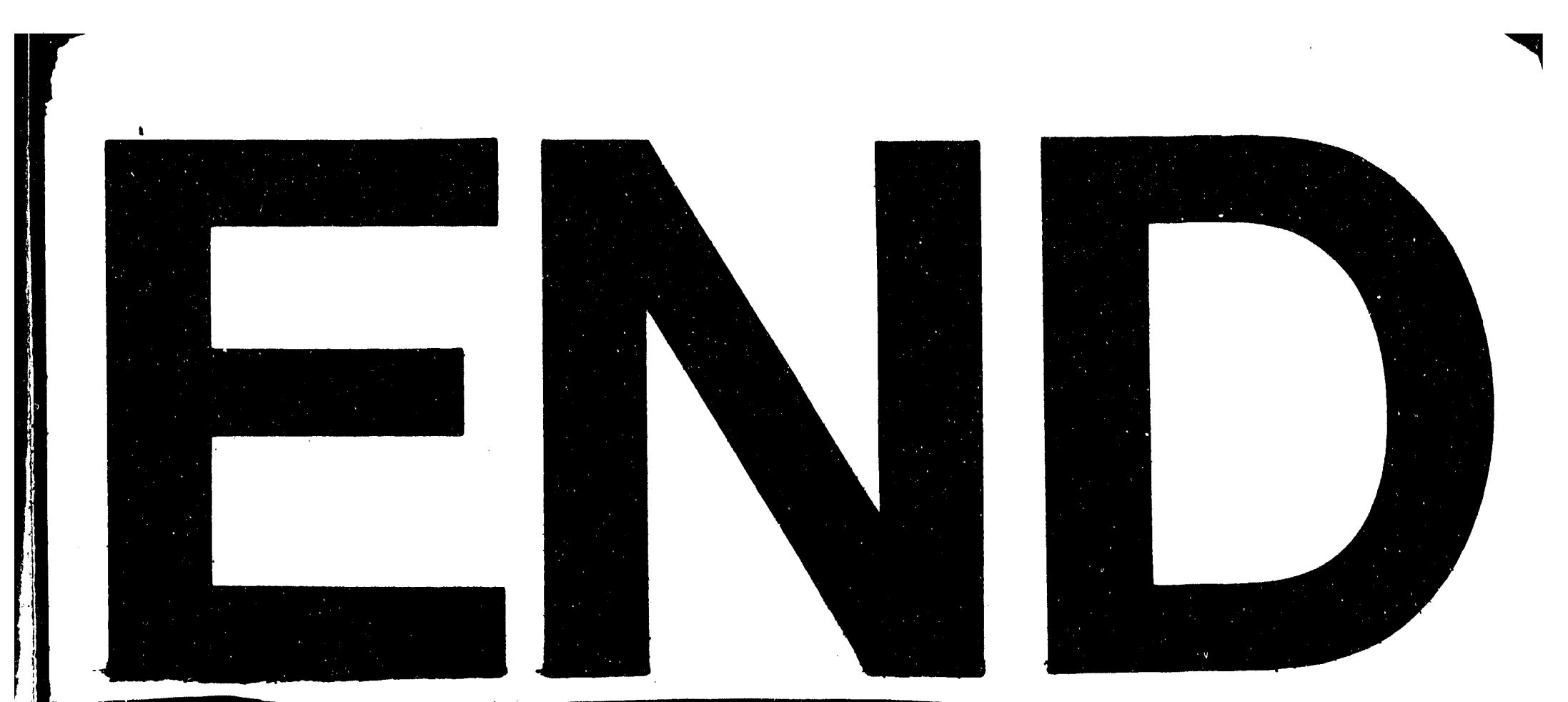

$\infty$

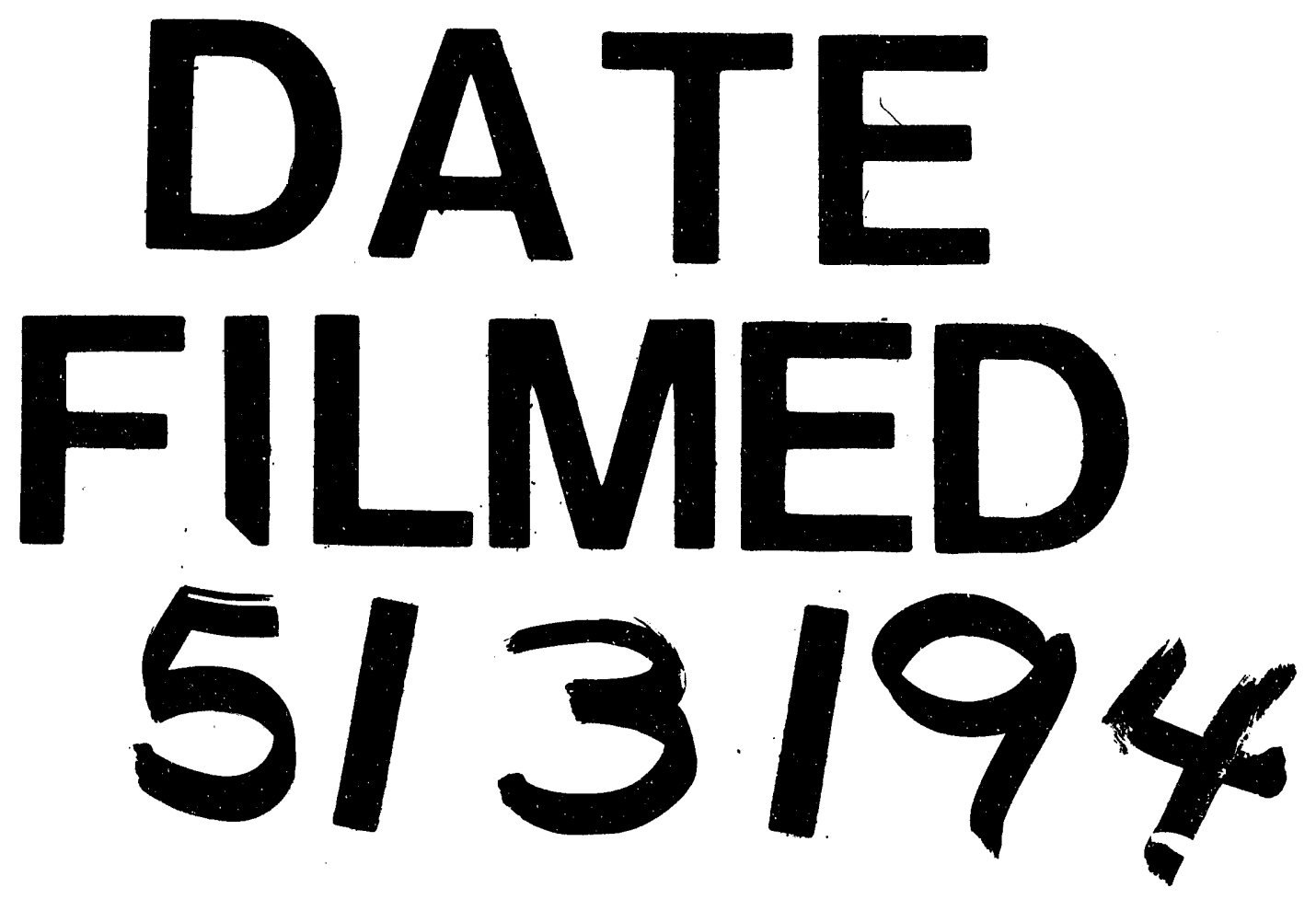


